\title{
POSIÇÃO DOS TERCEIROS MOLARES NA MÁ OCLUSÃO DE CLASSE II, SUBDIVISÃO
}

\author{
KARINA SANTANA CRUZ
}

Tese apresentada à Faculdade de Odontologia de Bauru, da Universidade de São Paulo, como parte dos requisitos para obtenção do título de Doutora em Odontologia, área de Ortodontia.

(Edição Revisada) 


\title{
POSIÇÃO DOS TERCEIROS MOLARES NA MÁ OCLUSÃO DE CLASSE II, SUBDIVISÃO
}

\author{
KARINA SANTANA CRUZ
}

Tese apresentada à Faculdade de Odontologia de Bauru, da Universidade de São Paulo, como parte dos requisitos para obtenção do título de Doutora em Odontologia, área de Ortodontia.

(Edição Revisada)

Orientador: Prof. Dr. Guilherme Janson.

BAURU

2003 


\begin{tabular}{|l} 
CRUZ, Karina Santana \\
C889p \\
Posição dos terceiros molares na má oclusão de \\
Classe II, subdivisão / Karina Santana Cruz. - Bauru, 2003. \\
194p.: il.; 30cm \\
Tese (Doutorado) - Faculdade de Odontologia de \\
Bauru. USP. \\
Orientador: Prof. Dr. Guilherme Janson.
\end{tabular}

Autorizo, exclusivamente para fins acadêmicos e científicos, a reprodução total ou parcial desta dissertação, por processos fotocopiadores e/ou meios eletrônicos.

Assinatura do autor (a):

Data:

Projeto de pesquisa aprovado pelo Comitê de Ética em Pesquisa da Faculdade de Odontologia de Bauru, Universidade de São Paulo, na reunião do dia 22 de fevereiro de 2001. 


\section{KARINA SANTANA CRUZ}

23 de Fevereiro de 1972

Aracaju-SE

1990-1994

1995-1997

1997-1999

$1998-2000$

$2001-2003$

2001

2002

2003

ASSOCIAÇÕES
Nascimento

Graduação em Odontologia pela Universidade Federal de Sergipe.

Aperfeiçoamento em Ortodontia Corretiva pela APCD - Regional - Bauru.

Especialização em Ortodontia e Ortopedia Facial pela Faculdade de Odontologia de Bauru-USP.

Curso de Mestrado em Ortodontia pela Faculdade de Odontologia de BauruUSP.

Curso de Doutorado em Ortodontia pela Faculdade de Odontologia de BauruUSP.

Professora do Curso de Especialização em Ortodontia e Ortopedia Facial da ABO-EAP/SE.

Coordenadora do Curso de Aperfeiçoamento em Ortodontia e Ortopedia Facial da ABO-EAP/SE.

Professora das Disciplinas de Ortodontia I e II do Curso de Graduação da Universidade Federal de Sergipe.

AAO - American Association of Orthodontics.

ABO - Associação Brasileira de Odontologia.

ABOR - Associação Brasileira de Ortodontia.

GBPOrO - Grupo Brasileiro de

Professores de Ortodontia e Odontopediatria.

SOSE - Sociedade Sergipana de Ortodontia.

WFO - World Federation of Orthodontics. 
"A última coisa que se encontra ao fazer uma obra é o que se deve colocar em primeiro lugar", (Pascal, Pensée, frase $n^{\circ} 19$ ) pois "sendo então todas as coisas causadas e causadoras, ajudadas e ajudantes, mediata e imediatamente, e todas se relacionando por um vínculo natural e insensivel que liga as mais afastadas e mais diferentes, creio ser tão impossivel conhecer as partes sem conhecer o todo como conhecer o todo, sem conhecer, particularmente, as partes".

(Pascal, Pensée, frase $n^{\circ} 73$ ) 
Dedicatória

A DEUS, por me fortalecer diante dos obstáculos encontrados nesta caminhada.

Aos meus queridos pais,

JORGE RESENDE CRUZ e

MARIA HELENA SANTANA CRUZ,

Por vocês existirem, pelo amor, carinho, apoio $e$ incentivo constantes, buscando sempre o melhor para a minha formação pessoal e profissional. Sempre vou lembrar de todos os sacrifícios que fizeram em prol da minha felicidade.

Minha eterna gratidão!!! 


\section{Meu profundo afeto}

Ao meu irmão, Jorge Flávio Santana Cruz e sua namorada Juliana, pelo apoio, carinho e incentivo constantes.

À minha irmã Kátia Santana Cruz e aos meus sobrinhos, Gabriel e Pedro, pelo carinho e estímulo sempre presentes.

Ao meu tio Marcos Santana e sua esposa Maria Esther, pela sua desenvoltura na política, como Secretário Geral do CFO, buscando sempre o melhor para a classe odontológica. Agradeço seus conselhos, apoio e amizade sempre presentes.

Aos meus tios João, Gilza e Tereza Santana e primos, pelas palavras de conforto com que sempre me brindaram. 


\title{
Meu reconhecimento e admiração
}

\section{Ao Professor Doutor \\ Coordenador do Curso de Mestrado em Ortodontia da FOB-USP GUILHERME JANSON,}

\begin{abstract}
Meu orientador, pelo exemplo de determinação, dedicação, disciplina e despreendimento à Ciência e à Especialidade da Ortodontia e Ortopedia Facial. Seu rigor científico, apurado senso crítico e objetividade nas orientações para a realização das várias etapas desta pesquisa, fortaleceram-me e me proporcionaram confiança para a concretização deste trabalho. Além da amizade, dos ensinamentos transmitidos, apoio e incentivos constantes que continuamente me estimulam na busca do conhecimento infinito.
\end{abstract}




\section{Agradecimento Especial}

\section{Ao Professor Doutor \\ Prefeito do Campus Administrativo da FOB-USP \\ JOSÉ FERNANDO CASTANHA HENRIQUES,}

Professor Titular e Coordenador do Curso de PósGraduação em Ortodontia, em nível de Doutorado, pelo incentivo profissional, orientações, conselhos e amizade transmitidos, durante toda a minha vida discente em Bauru. Certamente, nunca vou deixar de lembrar a atenção dispensada, disponibilidade e cordialidade com que sempre me atendeu nos vários momentos em que solicitei seu auxílio. 


\section{Agradecimentos Adicionais}

Ao Chefe de Departamento da FOB-USP, Prof. Dr. Marcos Roberto de Freitas, pelos conhecimentos transmitidos, confiança e amizade dispensados.

Aos demais Professores do Departamento de Ortodontia, Prof. Dr. Arnaldo Pinzan, Prof. Dr. Décio Rodrigues Martins, Prof. Dr. Renato Rodrigues de Almeida, pela valiosa contribuição para minha formação profissional.

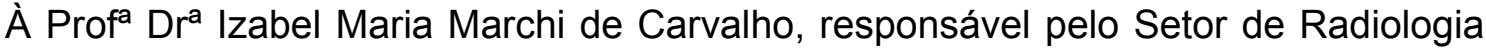
do Hospital de Reabilitação de Lesões Labiopalatais, por ter permitido a utilização dos aparelhos de raios $X$, para a obtenção das radiografias. Agradeço também ao Dr. Carlos Alberto Carvalho Pires, aos radiologistas, funcionários e residentes deste Setor, pelas orientações na utilização dos aparelhos e auxílio prestados.

Ao Prof. Dr. José Alberto de Souza Freitas, pela oportunidade em utilizar as dependências do Hospital de Reabilitação de Bauru.

Ao Prof. José Roberto Lauris, pelos esclarecimentos estatísticos.

Aos colegas e amigos do Curso de Doutorado em Ortodontia: Adriano Mondelli, Ana Carla Nahás, Ana Cláudia Conti, Daniela Garib-Carreira, Danilo Siqueira, Fausto Bramante, Karyna Valle-Corotti, Paulo Carvalho e Renata Almeida-Pedrin pela convivência agradável e laços de amizade.

Aos colegas do antigo Doutorado, Acácio Fiuzy, Alexandre Moro, Liliana Brangeli, Márcio Almeida, Maria Helena Vasconcelos e Ricardo Takahashi pelo convívio e amizade.

Aos colegas e amigos da pós-graduação Rejane Beltrão, Roberto Bombonatti, José Eduardo Souza, Fabrício Varalelli, Karina Lima, Leniana Neves, Rodrigo Cançado, 
Fernanda Angelieri, Célia Pinzan, Karina Freitas, Ana Lú Giampetro e Ricardo Navarro.

Aos alunos dos Cursos de Especialização da FOB-USP e Aperfeiçoamento da ACOPEN-Bauru pela amizade e convívio agradável.

Aos amigos de Bauru, Ivone e César, Valéria e Wilson e seus familiares pela atenção e cordialidade.

Aos colegas e professores da equipe dos Cursos de Especialização e Aperfeiçoamento em Ortodontia e Ortopedia Facial da ABO-SE, José Hermenergildo Santos Jr., Alexandre Franco, Luciano Almeida, Gustavo Barreto e Gustavo Rodrigues pelo apoio e compreensão.

Aos alunos dos Cursos de Especialização e Aperfeiçoamento em Ortodontia e Ortopedia Facial da ABO-SE, pela convivência e incentivo profissional.

À Chefe de Departamento de Odontologia da Universidade Federal de Sergipe (UFS), Prof ${ }^{a}$ Marta Rabello Piva, pela compreensão e cordialidade.

À Prof ${ }^{a}$ Dr $^{a}$ Sônia Alves Lima Novaes, responsável pelas Disciplinas de Odontopediatria e Ortodontia I e II da UFS, pelo apoio, compreensão e amizade em todos os momentos.

Aos alunos do Curso de Graduação da UFS.

Aos funcionários do Departamento de Ortodontia, Vera Lúcia Purgato, Maria José Formenti, Tereza Cristina Camaforte e Luís Sérgio Vieira, pela colaboração e amizade.

Aos funcionários da ACOPEN, Sônia Pinzan, Simone Del Rio, Luciana e César Formenti, pela cordialidade com que sempre me receberam. 
Aos funcionários da biblioteca da FOB-USP, pela atenção e serviços prestados.

Aos técnicos Daniel Rascão Selmo e Josué Amancio, pela colaboração em vários aspectos do campo da informática, além da amizade e solicitude.

Aos pacientes que muito contribuíram para o meu enriquecimento profissional.

A todos aqueles que me proporcionaram contribuições diretas e indiretas para o meu desenvolvimento profissional e pessoal.

\section{Agradecimentos Administrativos}

Ao Prof ${ }^{a}$. Dr ${ }^{a}$. Maria Fidela de Lima Navarro, Diretora da Faculdade de Odontologia de Bauru - USP.

Ao Prof. Dr. José Carlos Pereira, Presidente da Comissão de Pós-Graduação da Faculdade de Odontologia de Bauru - USP.

À Fundação de Amparo à Pesquisa do Estado de São Paulo (FAPESP), pela concessão da bolsa de estudo. 


\section{SUMÁRIO}

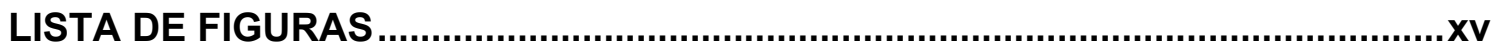

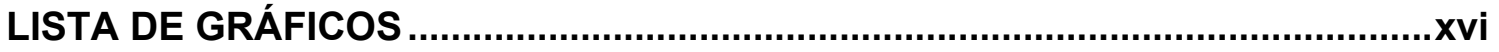

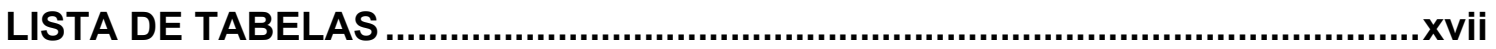

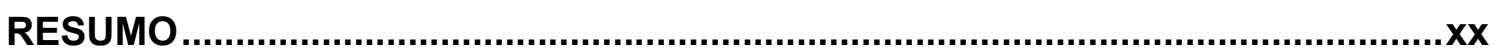

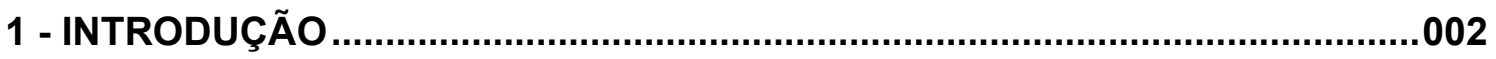

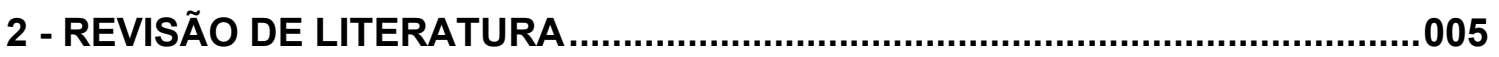

2.1 - Desenvolvimento dos terceiros molares ..................................................006

2.2 - Influência dos terceiros molares no apinhamento do arco inferior ................010

2.3 - O crescimento mandibular e os terceiros molares não irrompidos ...............015

2.4 - Posição e freqüência dos terceiros molares não irrompidos .......................028

2.5 - As extrações dentárias e a irrupção dos terceiros molares ..........................032

2.6 - A Classe II, subdivisão ................................................................... 042

2.7 - Relação entre a Classe II, subdivisão e a assimetria .................................048

2.8 - Técnicas radiográficas para a avaliação da posição do terceiro molar .......060

2.8.1 - Considerações sobre as radiografias submentonianas .....................061

2.8.2 - Considerações sobre as radiografias oblíquas ..............................066

2.8.2 - Considerações sobre as radiografias panorâmicas...........................070

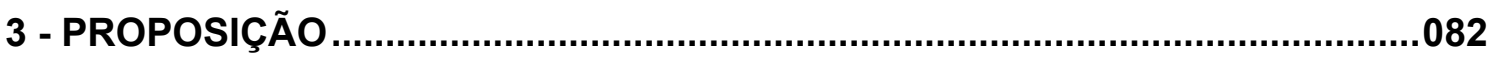

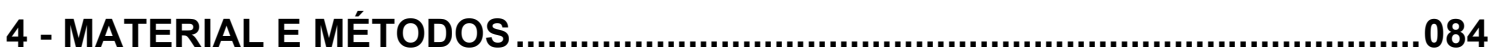

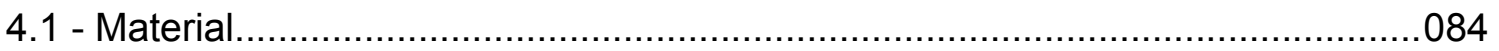

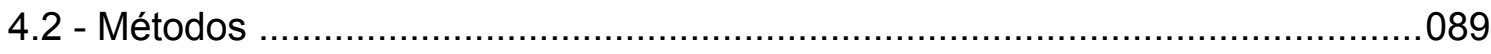

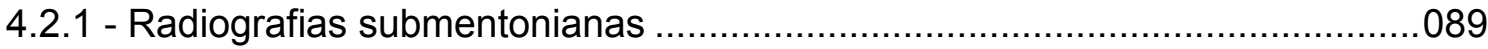

4.2.1.1 - Estruturas anatômicas...........................................................090

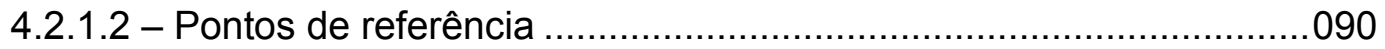

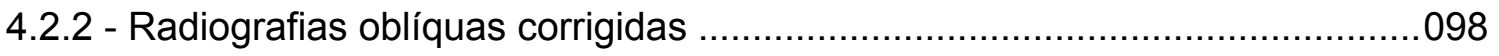


4.2.2.1 - Estruturas anatômicas.................................................................104

4.2.2.2 - Pontos de referência ...................................................................105

4.2.2.3 - Linhas de referência ...............................................................107

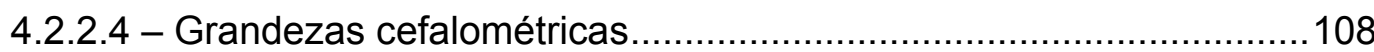

4.2.2.5 - Diferenças entre as medidas bilaterais ........................................109

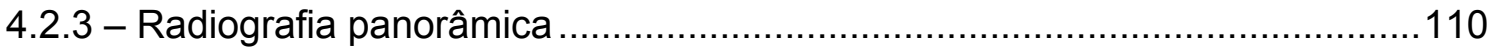

4.2.3.1 - Desenho anatômico das estruturas dentoesqueléticas ....................111

4.2.3.2 - Pontos de referência .................................................................111

4.2.3.3 - Linhas de referência ....................................................................113

4.2.3.4 - Grandezas cefalométricas....................................................113

4.2.3.5 - Diferenças entre as medidas bilaterais .......................................113

4.3 - ANÁLISE ESTATÍSTICA

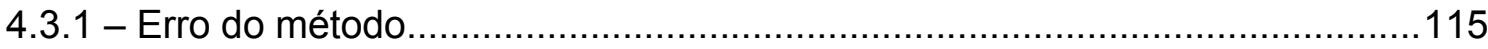

4.3.2 - Testes estatísticos utilizados ............................................................115

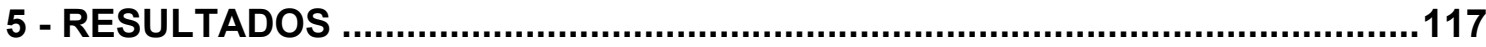

6 - DISCUSSÃO

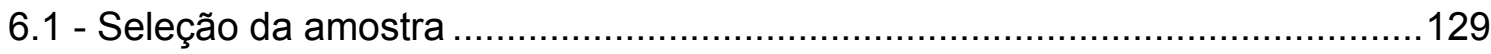

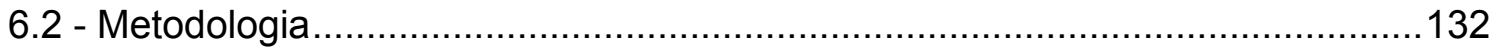

6.3 - Mensuração das grandezas em computador ………………........................135

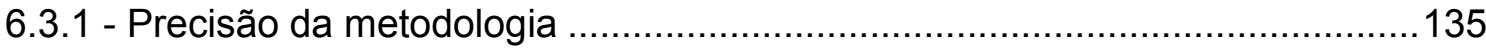

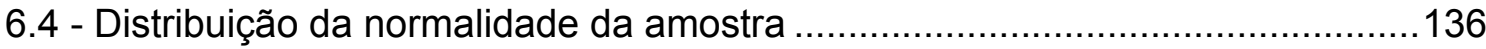

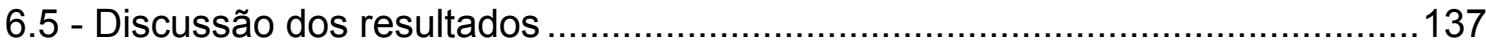

6.5.1 - Espaço para irrupção e angulação dos terceiros molares na

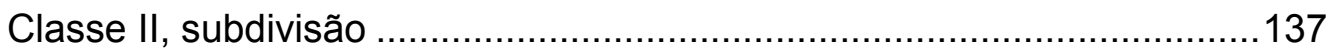

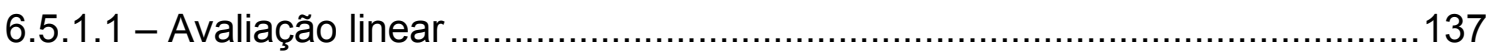

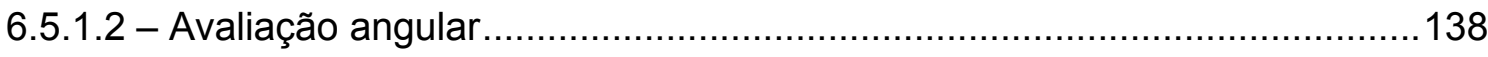

6.5.2 - Espaço para irrupção e angulação dos terceiros molares na

Classe II, subdivisão (Tipos 1 e 2) .........................................................141 
6.5.2.1 - Espaço para irrupção e angulação dos terceiros molares na Classe II, subdivisão (Subgrupo Tipo 1) .............................................143

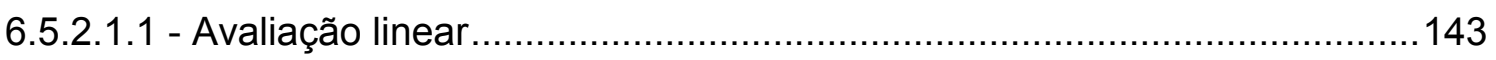

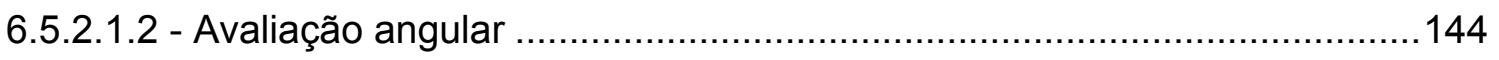

6.5.3 - Espaço para irrupção e angulação dos terceiros molares na Classe II, subdivisão (Subgrupo Tipo 2) .............................................146

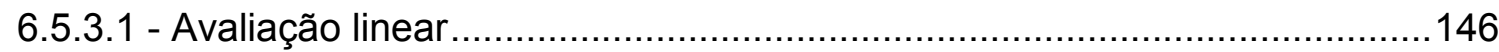

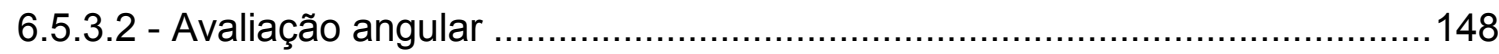

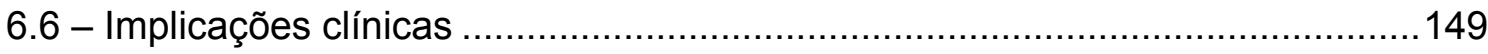

7 - CONCLUSÕES

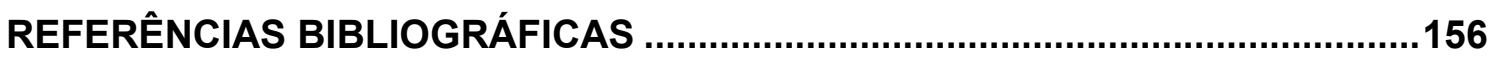

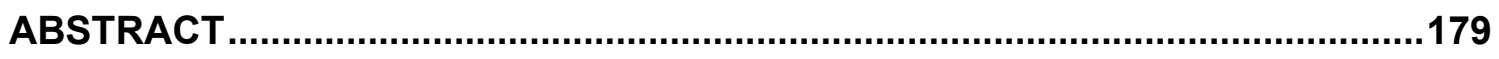

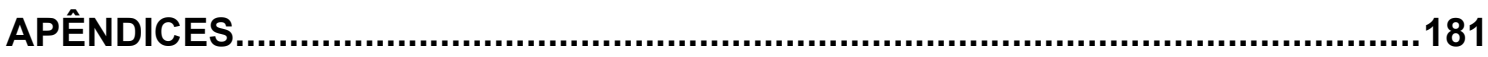




\section{LISTA DE FIGURAS}

Figura 4.1a- Fotografias intrabucais de um paciente pertencente ao Grupo 1 (Classe II, subdivisão).

Figura 4.1b- Fotografias dos modelos do mesmo paciente ilustrado anteriormente pertencente ao Grupo 1 (Classe II, subdivisão).

087

Figura 4.2- Fotografias intrabucais de um paciente pertencente ao Grupo 2 (oclusão normal).

Figura 4.3- Radiografia submentoniana.

095

Figura 4.4- Estruturas anatômicas da radiografia submentoniana.

096

Figura 4.5- Pontos de referência da radiografia submentoniana.

097

Figura 4.6- Estruturas anatômicas, pontos, linhas e grandezas cefalométricas utilizadas na radiografia submentoniana para a obtenção da radiografia oblíqua corrigida.

099

Figura 4.7- Representação das rotações do cefalostato para a obtenção das radiografias oblíquas a $45^{\circ}$ e corrigida.

Figura 4.8a- Radiografia oblíqua corrigida, lado direito.

101

Figura 4.8b- Radiografia oblíqua corrigida, lado esquerdo.

102

Figura 4.9- Estruturas anatômicas da radiografia oblíqua corrigida, lado esquerdo.

Figura 4.10- Pontos e linhas de referência da radiografia oblíqua corrigida, lado esquerdo.

Figura 4.11 Grandezas cefalométricas da radiografia oblíqua corrigida, lado esquerdo.

Figura 4.12- Radiografia panorâmica.

Figura 4.13- Desenho anatômico das estruturas dentoesqueléticas e pontos de referência da radiografia panorâmica.

Figura 4.14- Linhas de referência e grandezas cefalométricas da radiografia panorâmica. 


\section{LISTA DE GRÁFICOS}

Gráfico 1- Médias das assimetrias lineares obtidas pelo teste $t$ independente para a análise intergrupos, nas radiografias oblíquas corrigidas, entre os lados de Classe I e Classe II do grupo de Classe II, subdivisão (Grupo $1=\mathrm{G} 1$ ) com os lados esquerdo e direito do grupo de oclusão normal (Grupo 2 = G2).

Gráfico 2- Médias das assimetrias angulares nas radiografias oblíquas corrigidas e panorâmicas obtidas pelos testes $t$ independentes da análise intergrupos, entre os lados de Classe I e Classe II, do grupo de Classe II, subdivisão (Grupo $1=\mathrm{G} 1$ ) com os lados esquerdo e direito do grupo de oclusão normal (Grupo 2 = G2).

Gráfico 3- Médias das assimetrias lineares, nas radiografias oblíquas corrigidas, obtidas pelo teste $t$ independente, entre os lados de Classe I e Classe II do grupo de subgrupo Tipo 1 (G1-T1) com os lados esquerdo e direito do grupo de oclusão normal (G2).

Gráfico 4- Médias das assimetrias angulares obtidas pelos testes $t$ independentes, nas oblíquas corrigidas e panorâmicas, entre os lados de Classe I e Classe II, do subgrupo Tipo 1 (G1-T1) com os lados esquerdo e direito do grupo de oclusão normal (G2).

Gráfico 5- Médias das assimetrias lineares nas radiografias oblíquas corrigidas, obtidas pelo teste $t$ independente, entre os lados de Classe I e Classe II do subgrupo Tipo 2 (G1-T2) com os lados esquerdo e direito do grupo de oclusão normal (G2).

Gráfico 6- Médias das assimetrias angulares obtidas pelos testes $t$ independentes, nas radiografias oblíquas corrigidas e panorâmicas, entre os lados de Classe I e Classe II, do subgrupo Tipo 2 (G1-T2) com os lados esquerdo e direito do grupo de oclusão normal (G2). 


\section{LISTA DE TABELAS}

Tabela 1- Resultados do erro do método para as radiografias oblíquas corrigidas.

Tabela 2- Resultados do erro do método para as radiografias panorâmicas.

Tabela 3- Resultados do teste de normalidade (Kolmogorov-Smirnov) para o grupo 1 (Classe II, subdivisão), nas radiografias oblíquas corrigidas.

Tabela 4- Resultados do teste de normalidade (Kolmogorov-Smirnov) para o grupo 2 (oclusão normal), nas radiografias oblíquas corrigidas.

120

Tabela 5- Resultados do teste de normalidade (Kolmogorov-Smirnov) das assimetrias lineares e angulares entre os lados de Classe I e Classe II do Grupo 1 (Classe II, subdivisão) e entre os lados esquerdo e direito do Grupo 2 (oclusão normal).

Tabela 6- Resultados do teste de normalidade (Kolmogorov-Smirnov) para o grupo 1 (Classe II, subdivisão), nas radiografias panorâmicas.

Tabela 7- Resultados do teste de normalidade (Kolmogorov-Smirnov) para o grupo 2 (oclusão normal), nas radiografias panorâmicas.

Tabela 8- Resultados do teste de normalidade (Kolmogorov-Smirnov) das assimetrias angulares entre os lados de Classe I e Classe II do Grupo 1 (Classe II, subdivisão) e entre os lados esquerdo e direito do Grupo 2 (oclusão normal), nas radiografias panorâmicas.

Tabela 9- Resultados dos testes t pareados da comparação entre os lados de Classe I e Classe II do Grupo 1 (Classe II, subdivisão), nas radiografias oblíquas corrigidas.

Tabela 10- Resultados dos testes t pareados da comparação entre os lados esquerdo e direito do Grupo 2 (oclusão normal), nas radiografias oblíquas corrigidas.

Tabela 11- Resultados do teste $t$ independente da comparação das assimetrias lineares e assimetrias angulares dos terceiros molares do Grupo 1 (Classe II, subdivisão) com as do Grupo 2 (oclusão normal), nas radiografias oblíquas corrigidas. 
Tabela 12- Resultados dos testes $\mathrm{t}$ pareados da comparação entre os lados de Classe I e Classe II do Grupo 1 (Classe II, subdivisão), nas radiografias panorâmicas.

123

Tabela 13- Resultados dos testes $t$ pareados da comparação entre os lados esquerdo e direito do Grupo 2 (oclusão normal), nas radiografias panorâmicas.

Tabela 14- Resultados do teste $t$ independente da comparação das assimetrias angulares dos terceiros molares do Grupo 1 (Classe II, subdivisão) com as do Grupo 2 (oclusão normal), nas radiografias panorâmicas.

Tabela 15- Resultados dos testes $t$ pareados da comparação entre os lados de Classe I e Classe II do subgrupo Tipo 1 (Classe II, subdivisão - Tipo 1), nas radiografias oblíquas corrigidas.

Tabela 16- Resultados do teste $t$ independente da comparação das assimetrias lineares e angulares dos terceiros molares do subgrupo Tipo 1 (Classe II, subdivisão - Tipo 1) com as do Grupo 2 (oclusão normal), nas radiografias oblíquas corrigidas.

Tabela 17- Resultados dos testes t pareados da comparação entre os lados de Classe I e Classe II do subgrupo Tipo 1, nas radiografias panorâmicas.

Tabela 18- Resultados do teste $t$ independente da comparação das assimetrias angulares dos terceiros molares do subgrupo Tipo 1 com as do Grupo 2, nas radiografias panorâmicas.

Tabela 19- Resultados dos testes $t$ pareados da comparação entre os lados de Classe I e Classe II do subgrupo Tipo 2, nas radiografias oblíquas corrigidas.

Tabela 20- Resultados do teste $t$ independente da comparação das assimetrias lineares e angulares dos terceiros molares do subgrupo Tipo 2 com as do Grupo 2, nas radiografias oblíquas corrigidas.

Tabela 21- Resultados dos testes $t$ pareados da comparação entre os lados de Classe I e Classe II do subgrupo Tipo 2, nas radiografias panorâmicas.

Tabela 22- Resultados do teste $t$ independente da comparação das assimetrias angulares dos terceiros molares do subgrupo Tipo 2 com as do Grupo 2, nas radiografias panorâmicas. 


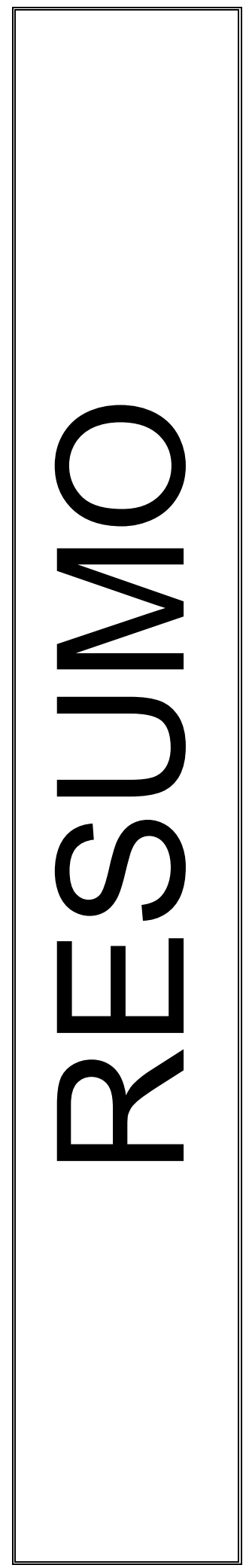




\section{RESUMO}

Este trabalho objetivou comparar os espaços destinados à irrupção dos terceiros molares superiores e inferiores, e suas angulações, de ambos os lados, na má oclusão de Classe II, subdivisão. A amostra foi composta de um grupo experimental (grupo 1) contendo 29 pacientes, com más oclusões de Classe II, subdivisão, apresentando relação dos molares de Classe II completa de um lado e Classe I do outro lado, sendo 17 do gênero masculino e 12 do feminino, com média de idade de 14,73 anos. Dois subgrupos foram classificados dentre o total de casos do grupo 1, de acordo com duas etiologias da Classe II, subdivisão: subgrupo Tipo 1 (18 casos) caracterizado pela coincidência da linha média dentária superior em relação ao plano sagital mediano e desvio da linha média inferior em direção ao lado da Classe II. O subgrupo Tipo 2 (6 casos) apresentava coincidência da linha média dentária inferior em relação ao plano sagital mediano e desvio da linha média dentária superior em sentido contrário ao lado da Classe II. O grupo controle de oclusão normal (grupo 2) constituiu-se de 17 pacientes, sendo 11 do gênero feminino e seis do masculino, com média de idade de 21,73 anos. Foram obtidas quatro radiografias: uma submentoniana, duas oblíquas corrigidas (lados direito e esquerdo) e uma panorâmica dos 46 participantes desta pesquisa. Os testes $\mathrm{t}$ pareados de Student foram empregados nas comparações entre os lados de cada grupo e subgrupos, individualmente. Foram realizados os testes $t$ independentes para as comparações das assimetrias lineares e angulares do espaço e das angulações dos terceiros molares do grupo e subgrupos experimentais com o grupo controle. Os resultados demonstraram que houve diferenças nos espaços disponíveis superior e inferior e nas angulações dos terceiros molares inferiores entre os lados de Classe I e de Classe II, na má oclusão de Classe II, subdivisão. No subgrupo Tipo 1, os espaços disponíveis para os terceiros molares superiores e inferiores $e$ as angulações dos terceiros molares inferiores refletiram as características do posicionamento dentoalveolar em suas bases apicais nesse tipo de má oclusão. No subgrupo Tipo 2, os espaços disponíveis para os terceiros molares superiores e suas angulações tenderam a refletir as características assimétricas dentoalveolares deste grupo. 


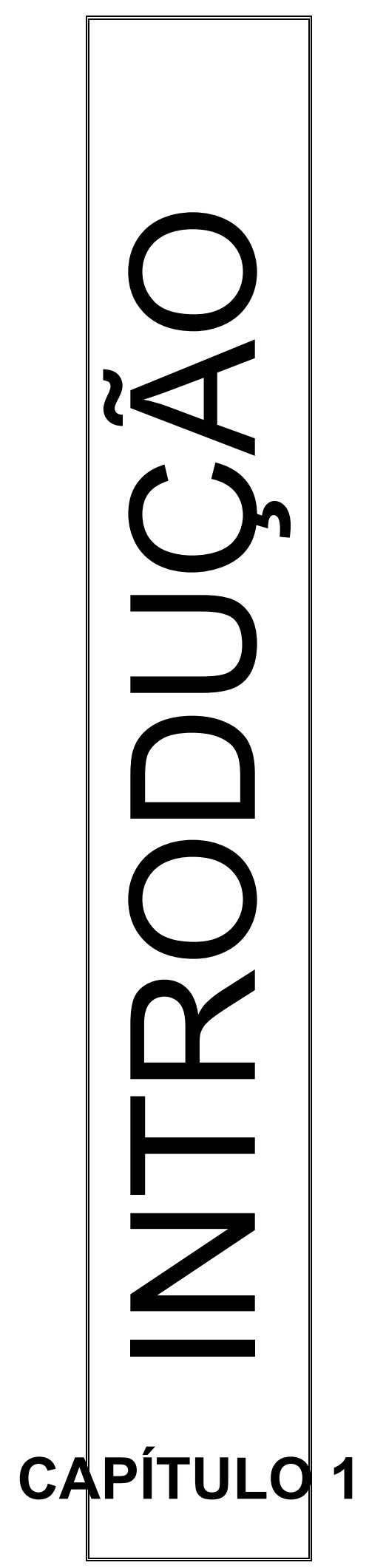




\section{INTRODUÇÃO}

desenvolvimento dos terceiros molares e sua influência nos arcos dentários são de grande importância ${ }^{54}$. Os terceiros molares não irrompidos têm sido associados a várias condições patológicas incluindo pericoronarite, cisto dentígero, tumor, cáries dentárias, periodontites, infecção periapical e reabsorção radicular dos dentes adjacentes ${ }^{116}$. Os terceiros molares em posição mesioangulada ou horizontal podem causar um impacto no apinhamento ântero-inferior e na estabilidade do tratamento ortodôntico ${ }^{116}$.

Quanto à impacção dos terceiros molares, inicialmente, não foram encontradas diferenças significantes em relação à prevalência ser unilateral ou bilateral ${ }^{30,58,161}$. Sugeriu-se mais tarde que havia mais apinhamento no quadrante em que o terceiro molar estava presente em relação ao hemiarco que apresentava agenesia dentária ${ }^{17}$. Observou-se uma variação considerável no grau de angulação destes dentes de um indivíduo para outro e mesmo entre os lados direito e esquerdo do mesmo paciente ${ }^{135}$. Foram verificadas que as discrepâncias bilaterais de posição e irrupção dos terceiros molares não irrompidos consistem em fenômenos imprevisíveis, podendo a assimetria bilateral estar presente nas alterações de angulação e movimento eruptivo ${ }^{54,175}$. Após um período de observação de quatro anos, constatou-se que as alterações médias nas angulações dos terceiros molares, ao se comparar ambos os lados, foram semelhantes, não havendo diferenças estatisticamente significantes ${ }^{54}$. Mais recentemente, conferiu-se que havia assimetria do espaço retromolar entre os lados esquerdo e direito em relação à impacção e irrupção dos terceiros molares, entretanto, não foram encontradas diferenças significantes nas angulações destes dentes ${ }^{55}$. Apesar de ter sido constatada a possibilidade de assimetrias do espaço retromolar entre os lados esquerdo e direito quanto a impacção e irrupção dos terceiros molares, essas assimetrias não foram relacionadas às diferentes más oclusões.

Verificou-se, inicialmente que a Classe II, subdivisão resultava principalmente de uma assimetria de posição dos molares inferiores, embora não se tenha 
discriminado se a origem do problema seria dentária, esquelética ou uma combinação de ambas as características ${ }^{3}$. Mais tarde, confirmou-se que a Classe II, subdivisão era geralmente causada pela posição mais posterior do molar inferior, no lado da Classe II, do que no lado da Classe $\mathrm{I}^{145}$. Posteriormente, concluiu-se que os componentes mais freqüentes que contribuem para a relação ântero-posterior assimétrica na Classe II, subdivisão eram dentoalveolares, sendo que a principal diferença entre a má oclusão de Classe II, subdivisão e a oclusão normal consiste numa posição mais para distal do primeiro molar inferior do lado da Classe II, em uma base óssea com assimetria normal ${ }^{65,145}$. Uma diferença secundária consistia na posição mais para mesial do primeiro molar superior, no lado da Classe ${ }^{1{ }^{65,66}}$. Como conseqüência destas diferenças de posicionamentos ântero-posteriores entre os primeiros molares, especulou-se que haveria um reflexo no espaço disponível para os terceiros molares. Desta forma, realizou-se esta pesquisa, objetivando avaliar se os espaços destinados à irrupção dos terceiros molares superiores e inferiores e suas angulações sofrem influência das assimetrias ântero-posteriores dos dentes posteriores homólogos, na Classe II, subdivisão. 


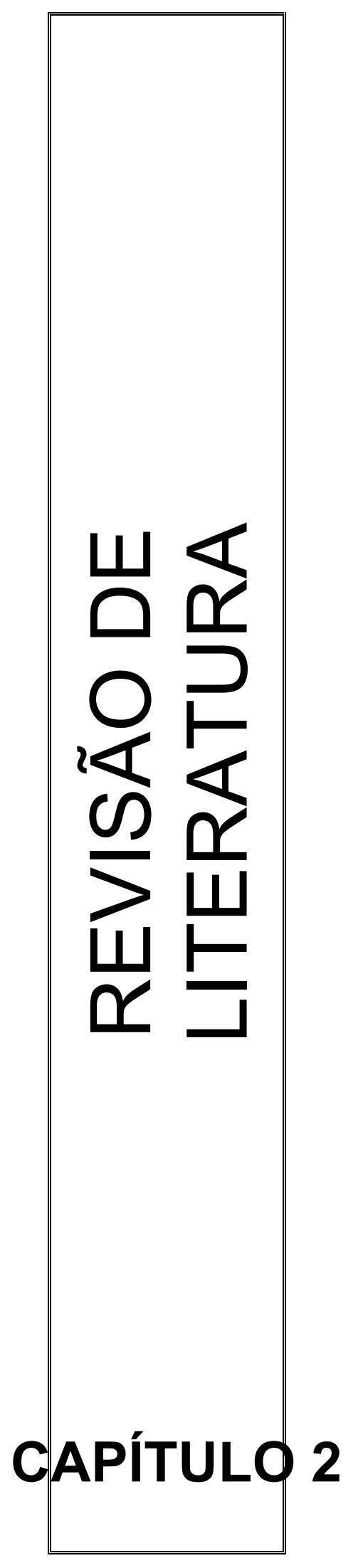




\section{REVISÃO DE LITERATURA}

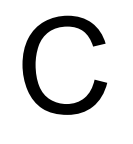

om a finalidade de facilitar a compreensão e a interpretação dos resultados desta pesquisa e de suas implicações clínicas, dividiuse este capítulo de acordo com a seqüência descrita abaixo:

2.1 - Desenvolvimento dos terceiros molares.

2.2 - Influência dos terceiros molares no apinhamento do arco inferior.

2.3 - O crescimento mandibular e os terceiros molares não irrompidos.

2.4 - Posição e freqüência dos terceiros molares não irrompidos.

2.5 - As extrações dentárias e a irrupção dos terceiros molares.

2.6 - A Classe II, subdivisão.

2.7 - Relação entre a Classe II, subdivisão e a assimetria.

2.8 - Técnicas radiográficas para a avaliação da posição do terceiro molar.

2.8.1 - Considerações sobre as radiografias submentonianas.

2.8.2 - Considerações sobre as radiografias oblíquas corrigidas.

2.8.2 - Considerações sobre as radiografias panorâmicas. 


\subsection{Desenvolvimento dos terceiros molares}

O desenvolvimento do terceiro molar inferior ocorre no ramo mandibular. Sua superfície oclusal está direcionada para cima e para frente e à medida que o espaço se torna disponível, decorrente do crescimento mandibular, este dente irrompe para uma posição mais verticalizada ${ }^{132}$. Entretanto, ainda em relação aos terceiros molares inferiores, se houver espaço insuficiente e uma rotação pré-eruptiva, o molar inicia sua irrupção em direção a uma inclinação anormal do seu longo eixo, sua coroa move-se direcionada à coroa ou raiz do segundo molar inferior, acompanhando este movimento. O desenvolvimento do terceiro molar ocorre entre as idades dos sete aos 14 anos com o pico de formação aos oito ${ }^{41}$ ou nove anos ${ }^{51}$.

Nos estágios iniciais do desenvolvimento do terceiro molar inferior, sua cripta deposita-se na superfície óssea, ficando submersa, enquanto se calcifica ${ }^{60}$. A idade de irrupção é bem variável, sempre após os 16 anos, com média de idade de 20,5 $\operatorname{anos}^{62}$. Além disso, suspeitou-se que o terceiro molar inferior geralmente torna-se impactado devido à falta de crescimento mandibular para permitir sua irrupção.

Sobre o ponto de vista ortodôntico, FORD ${ }^{37}$ (1940) comentou que os terceiros molares geralmente são responsáveis pelos distúrbios da oclusão. A impacção dos terceiros molares numa dentição normal pode ocasionar más oclusões nos casos em que não foram submetidos ao tratamento ortodôntico. Exames radiográficos periódicos após os 16 anos auxiliam na determinação do crescimento normal do paciente. A posição inclinada dos terceiros molares no estágio de desenvolvimento precoce não indica impacção. As extrações dos terceiros molares não devem ser indicadas até o crescimento do indivíduo ter cessado, não devendo se adotar as extrações em dentes com rizogênese incompleta, por razões cirúrgicas e de desenvolvimento. Um caso ortodôntico não deve ser considerado finalizado até os terceiros molares terem irrompido em posição normal ou terem sido extraídos.

Num estudo longitudinal de 140 jovens leucodermas americanos, GARN; LEWIS; BONNÉ ${ }^{40}$ (1962) investigaram a calcificação e o movimento dos terceiros molares inferiores por meio de radiografias oblíquas e telerradiografias. Verificaram 
que, em sua formação, o terceiro molar inferior não evidenciou diferença significante quanto ao gênero com relação à época de irrupção. A inter-relação entre o crescimento somático e a maturação sexual foi baixa e insignificante e enfatizou que o terceiro molar apresenta autonomia no desenvolvimento dentário.

Em sua revisão de literatura, SALZMANN ${ }^{149}$ (1966) descreveu que o início do desenvolvimento do terceiro molar inferior ocorre dos sete aos 15 anos de idade. $\mathrm{O}$ terceiro molar inferior é formado dentro do ramo da mandíbula; as superfícies oclusais estão inclinadas suavemente para frente e ligeiramente para lingual. Assim que a mandíbula vai se desenvolvendo em comprimento, suas raízes deslizam para frente, permitindo sua irrupção normal que ocorre entre os 15 aos 21 anos ou até mais tarde. Quando da ausência de razões específicas, afirmou que a decisão de extração dos terceiros molares não irrompidos só deve ser indicada quando houver $2 / 3$ de raiz formada e coroa completa.

Os terceiros molares inferiores se localizam numa área de considerável interesse para os ortodontistas. SILLING ${ }^{169}$, em 1973, avaliou em telerradiografias o comportamento e a irrupção dos terceiros molares inferiores em 100 casos pré e pós-tratamento ortodôntico sem extrações. Considerou que a idade dos oito anos e quatro meses foi a mais precoce, e 12 anos e nove meses, a idade mais tardia para poderem ser visualizados. Concluiu que o desenvolvimento normal dos terceiros molares só se inicia quando ocorre a mesialização de suas coroas até entrar em contato com os segundos molares inferiores em desenvolvimento. A falta de espaço na área retromolar é incrementada, ocasionando a impacção dos terceiros molares inferiores, quando se utilizam dispositivos ortodônticos que visam a distalização dos primeiros e segundos molares inferiores. A terapia não extracionista induz a impacção dos terceiros molares. Quando se realizam extrações no segmento posterior do arco inferior há uma diminuição da incidência de impacção em virtude do encorajamento do desenvolvimento normal da irrupção dos germes dos terceiros molares. 
De acordo com TAIT $^{176}$, em 1978, a idade em que as criptas dos terceiros molares podem ser visualizadas nas radiografias varia amplamente entre os indivíduos. Ocasionalmente, podem ser vistas aos cinco anos ou mais tarde aos 16 anos. Entretanto, freqüentemente podem ser detectadas aos 10 anos de idade. Comentou que, para a maioria dos indivíduos, a extração de dentes do segmento posterior, como os segundos molares, após os 10 anos de idade, não promove efeitos positivos na inclinação inicial dos germes dos terceiros molares inferiores. Afirmou que para se evitar a impacção dos terceiros molares por meio da extração de outros dentes devem ser consideradas duas situações distintas: 1- promover espaço para que os terceiros molares irrompam sem impedimentos, caso não se mostrem severamente inclinados ou mal posicionados; 2- melhorar a angulação dos terceiros molares ao início de seu desenvolvimento pelas extrações precoces que encorajam o deslizamento mesial das criptas dos terceiros molares, antes do desenvolvimento.

RICHARDSON $^{132}$, neste mesmo ano, ressaltou importantes alterações da inclinação dos terceiros molares inferiores entre as idades de 16 e 18 anos, e constatou que a correta movimentação do terceiro molar não resulta necessariamente em seu irrompimento, pois o contato com o segundo molar pode impedi-lo, podendo causar uma impacção mesioangulada. As impacções mesioanguladas e horizontais dos terceiros molares inferiores freqüentemente possuem uma raiz distal mais longa curvada para mesial.

Em 1983, ENGSTRÖM; ENGSTRÖM; SAGNE ${ }^{34}$ salientaram que o desenvolvimento dos terceiros molares relaciona-se mais com a maturidade esquelética, verificada pela mineralização das epífises das falanges da mão, do que com a idade cronológica. Para tanto, utilizaram 211 pacientes, sendo 123 do gênero feminino e 88 do gênero masculino selecionados aleatoriamente na clínica do Departamento de Ortodontia da Faculdade de Odontologia da Universidade de Göteborg, na Suécia. Os estágios de irrupção dos terceiros molares inferiores foram determinados por meio de radiografias panorâmicas, sendo divididos em categorias: A - germe dentário visível como uma imagem radiolúcida esférica; B - mineralização 
da cúspide completa; C - mineralização da coroa completa; D - raiz parcialmente formada; E - raiz completamente formada com rizogênese incompleta. Em 37 pacientes, radiografias da mão e punho foram realizadas, utilizando-se como parâmetro os seguintes centros de ossificação para a avaliação do desenvolvimento esquelético: PP2 - falange proximal do indicador, a epífise está tão ampla quanto à diáfise; MP3cap. - falange média do terceiro dedo, a epífise encapsula a diáfise; DP3u - falange distal do terceiro dedo, com a união completa da epífise; Ru epífise distal do rádio, com união epifiseal completa. Avaliaram por meio de correlação e análise de regressão linear, sendo que as diferenças entre os gêneros testadas pelos testes $t$ de Student. Concluíram que não houve dimorfismo sexual, embora o desenvolvimento pareceu ocorrer suavemente mais cedo nos meninos do que nas meninas. De um modo geral, houve uma forte correlação entre a idade cronológica e maturidade esquelética e entre o desenvolvimento dos terceiros molares inferiores e a maturidade esquelética. No estágio PP2, os terceiros molares inferiores mostraram sinais de mineralização completa da coroa na maioria dos casos. No estágio MP3cap. apresentaram suas coroas completamente formadas na maioria dos casos e o desenvolvimento radicular iniciou-se em alguns pacientes. No estágio DP3u, as coroas dos terceiros molares inferiores estavam ainda incompletas em alguns jovens, mas em outros já apresentavam rizogênese completa. No estágio $\mathrm{Ru}$, somente as coroas estavam completas em $1 / 3$ dos pacientes. Metade das raízes se desenvolveu parcialmente, enquanto a outra metade desenvolveu todo o seu comprimento. A ausência de um ou ambos os terceiros molares inferiores foi observada em $11 \%$ dos casos. Estes resultados indicaram que o desenvolvimento dos terceiros molares inferiores parece estar relacionado com a maturidade esquelética.

RICHARDSON; MALHOTRA; SEMENYA ${ }^{130}$, em 1984, realizaram um estudo longitudinal, utilizando três tipos de radiografias, em 20 americanos melanodermas para investigar a irrupção do terceiro molar. Cada paciente apresentava dois terceiros molares presentes. Quarenta terceiros molares foram estudados por meio de cefalogramas laterais, radiografias póstero-anterior e oblíquas a $45^{\circ}$, além de modelos de estudo. Os critérios analisados em relação aos terceiros molares foram: 
a) a idade em que eles podem ser identificados; b) a angulação da superfície oclusal; c) a direção de irrupção, incluindo a posição vertical, ântero-posterior e vestibulolingual e, d) a idade limítrofe entre estar irrompido ou impactado, incluindo a associação destes fatores. O teste estatístico de precisão de Fischer foi aplicado para auxiliar a interpretação dos dados. Em alguns pacientes, a cripta do terceiro molar foi vista precocemente aos 7,5 anos e a superfície oclusal foi identificada aos oito anos, com uma média de 9,75 anos. Os terceiros molares geralmente se formam no ramo com a cúspide distal acima do plano oclusal; a superfície oclusal do molar tem uma grande chance de se inclinar anteriormente; o dente se posiciona abaixo do plano oclusal e somente parece se verticalizar aos 14 ou 16 anos de idade. A impacção dos terceiros molares inferiores consiste em um mecanismo multifatorial complexo. A ampla localização vestibular dos terceiros molares inferiores e o espaço ântero-posterior inadequado entre a superfície distal do segundo molar e a borda anterior do ramo são importantes fatores na impacção do terceiro molar.

\subsection{Influência dos terceiros molares no apinhamento do arco inferior}

O relacionamento entre os terceiros molares e o apinhamento ântero-inferior tem sido debatido por muitos anos, havendo grande controvérsia na Ortodontia ${ }^{137}$. O apinhamento pode ocorrer em qualquer região, porém freqüentemente pode ser visto no segmento ântero-inferior ${ }^{137}$. O apinhamento dos incisivos inferiores resulta da falta de espaço na região retromolar e os terceiros molares desempenham um importante papel no apinhamento ântero-inferior ${ }^{137,138}$.

BROADBENT ${ }^{22}$ (1943) baseando-se em evidências cefalométricas relatou que a impacção dos terceiros molares não ocasiona apinhamento inferior, mas relaciona-se ao crescimento mandibular tardio decorrente de um retardo do desenvolvimento do esqueleto facial. Correlacionou o desenvolvimento facial normal e o irrompimento dos terceiros molares. Desta forma, com o crescimento normal da face, haveria espaço suficiente para a irrupção de todos os dentes em posições adequadas nos arcos. Quando da época de irrupção dos dentes permanentes, se 
os ossos de suporte não estivessem harmoniosos com eles, haveria uma tendência de assumir a posição que ocupavam quando o osso estava em um estágio mais jovem. Assim, o retardamento no processo de desenvolvimento dos ossos estava diretamente relacionado ao grau de má oclusão e más posições dentárias. Acreditava que importantes alterações na inclinação axial dos terceiros molares inferiores ocorriam entre as idades dos 16 aos 18 anos quando as raízes destes dentes se verticalizam no alvéolo.

Objetivando determinar em que extensão os terceiros molares são responsáveis pelo apinhamento secundário, BERGSTRÖM; JENSEN ${ }^{17}$ (1961) examinaram transversalmente 60 estudantes de Odontologia que apresentavam agenesia unilateral do terceiro molar e verificaram que 27 apresentavam agenesia de um terceiro molar inferior. Pelos modelos de gesso, fizeram comparações entre os lados direito e esquerdo para se avaliar as condições de espaço nos dois lados de cada arco e assimetrias mesiodistais dos segmentos laterais do arco. Também mensuraram o deslocamento de linha média. Os resultados sugeriram que não havia mais apinhamento no quadrante em que o terceiro molar estava presente e constataram um deslocamento mesial dos segmentos dentários no lado em que o terceiro molar inferior estava presente, mas não no arco superior. Concluíram que a presença de um terceiro molar pareceu exercer alguma influência sobre o desenvolvimento do arco dentário, mas não na extensão que justificasse a remoção do germe dentário ou a extração dos terceiros molares a não ser em circunstâncias excepcionais.

Em um estudo longitudinal, VEGO ${ }^{182}$ (1962) comparou 40 pacientes com os terceiros molares presentes e 25 casos com agenesia dos terceiros molares inferiores. Nenhum dos pacientes selecionados havia recebido tratamento ortodôntico. Cada arco foi medido quanto à quantidade de apinhamento em dois intervalos de tempo: após a irrupção dos segundos molares aos 13 anos de idade e, posteriormente, em média, aos 19 anos de idade. O apinhamento foi definido como a perda do perímetro do arco manifestado pelo fechamento do espaço ou ausência de contatos, resultando em rotação ou movimentação dentária adversa. Verificou 
que em todos os 65 casos, o perímetro do arco apresentava uma redução do primeiro para o segundo modelo. Isto foi expresso como um aumento na severidade dos dentes girados ou mal alinhados. A redução no perímetro do arco foi menos perceptível nos indivíduos sem os terceiros molares inferiores. Concluiu que os terceiros molares inferiores em irrupção podem exercer uma força sobre os dentes adjacentes.

SHENEMAN $^{165}$ (1968) avaliou 49 pacientes, cinco anos e meio após o tratamento ortodôntico, 11 com os terceiros molares irrompidos, 31 não irrompidos e sete casos com agenesias bilaterais. Observou que os casos com agenesias mostraram-se mais estáveis no segmento ântero-inferior, comparando-se aos outros dois grupos.

Neste mesmo ano, BROWN ${ }^{23}$, comentando sobre a impredictibilidade do comportamento eruptivo dos terceiros molares, ressaltou que o problema do moderado apinhamento ântero-inferior tem sido resolvido em casos ortodônticos pela extração dos dentes posteriores do arco. Entretanto, assegurou que esta terapia não resolve o apinhamento ântero-inferior, mas pode prevenir a sua piora na adolescência. Quando os terceiros molares estão ausentes, há uma esperança que qualquer apinhamento que surja com a idade seja mais ameno. Desta forma, descreveu o tratamento de um jovem com 11,5 anos de idade, com suave Classe II, divisão 1, apresentando terceiros molares presentes. Avaliou, em intervalos de tempo regulares até os 16,5 anos, por meio de radiografias oblíquas, a angulação destes dentes durante o seu processo de irrupção. Concluiu que nem sempre uma boa angulação inicial dos terceiros molares implica em uma posição final satisfatória. Além disso, afirmou que se a angulação inicial apresentada por um germe de terceiro molar for maior do que $45^{\circ}$, então há a possibilidade de que uma impacção mésio-angular seja convertida em uma impacção horizontal.

TURLEY ${ }^{180}$ (1974) constatou que a probabilidade de irrupção está diretamente relacionada com a disponibilidade de espaço retromolar, medida da face distal do segundo molar inferior ao ponto $\mathrm{Xi}$, no arco inferior e da face distal do 
primeiro molar superior à linha PTV, no arco superior. Estabeleceu um gráfico de probabilidade de irrupção, verificando que a partir de $30 \mathrm{~mm}$, a probabilidade de irrupção em uma boa oclusão para o arco inferior ultrapassa 80\% (erro padrão = 0,24mm). Utilizando esta curva, pode-se considerar a influência da extração dos pré-molares na condição de irrupção do terceiro molar. Por exemplo, considerandose a extração de um pré-molar com $7 \mathrm{~mm}$ e presumindo uma utilização de $3 \mathrm{~mm}$ com a retração do canino, restam $4 \mathrm{~mm}$ para a mesialização do primeiro e segundo molares, proporcionando maior espaço para o terceiro molar, aumentando a probabilidade de irrupção em aproximadamente $40 \%$. As possibilidades diferem para cada planejamento. Para a realização de previsões em idades precoces, estima-se o crescimento mandibular, associando o planejado (VTO - RICKETTS ${ }^{143}$, 1983) para finalmente se aplicar o gráfico. Neste caso, há erro padrão de $2,8 \mathrm{~mm}$, tornando o método menos preciso. Porém, se a estimativa demonstrar mais de $50 \%$ de possibilidades de impacção e menos de $10 \%$ de irrupção em boa oclusão, a impacção deve ocorrer e a extração pode ser indicada. No arco superior, os terceiros molares necessitam de pelo menos $18 \mathrm{~mm}$ entre a face distal do primeiro molar permanente e a linha PTV para uma adequada irrupção. Mesmo tendo optado pela extração dos terceiros molares, o paciente não fica livre do apinhamento já que a impacção dos terceiros molares relaciona-se com uma discrepância negativa implícita em todo o arco inferior ${ }^{137,139}$. Talvez os desgastes interproximais nos incisivos inferiores possam contribuir para a correção do apinhamento suave. Além disso, a contenção do alinhamento dos incisivos, mediante a utilização de barras linguais coladas deve ser mais prolongada. Finalmente, quando os terceiros molares apresentam condições favoráveis para irromper em boa oclusão, o apinhamento não deve ser justificativa para a extração. Como estes dentes constituem mais um sinal da discrepância dentoalveolar do que causadores ativos do apinhamento, a simples extração geralmente não soluciona o problema. Além disto, sugere-se que o desenvolvimento dos terceiros molares e não simplesmente sua irrupção é que provoca a migração mesial, embora pequena do segmento posterior $^{139}$. 
Investigando casos tratados ortodonticamente quanto ao espaço destinado à irrupção dos terceiros molares, KAPLAN ${ }^{75}$ (1975) avaliou 50 pacientes caucasianos, utilizando-se de radiografias cefalométricas pré, pós-tratamento e pós-contenção. Desta amostra, um grupo consistia de 30 casos que apresentavam os terceiros molares irrompidos com bom alinhamento, tamanho e forma e um grupo de 20 casos com terceiros molares não irrompidos. Concluiu que quando os pré-molares eram extraídos como parte da terapia ortodôntica havia: a) um aumento da mesialização do molar e maior probabilidade de irrupção do terceiro molar; b) quando a impacção dos terceiros molares persistia era devido à reabsorção insuficiente da borda anterior do ramo; c) casos com terceiros molares não irrompidos não exibiam comprimento mandibular mais encurtado do que os casos com terceiros molares irrompidos.

RALLEY; CHAPNICK; BAKER ${ }^{127}$, em 1977, afirmararam que a impacção mesioangular ou horizontal dos terceiros molares pode exercer uma força anterior que é transmitida ao arco dentário com resultante anterior, provocando apinhamento ântero-inferior. Em alguns casos, a recidiva da má oclusão pode ocorrer, mesmo quando previamente corrigida ortodonticamente. A remoção dos terceiros molares não irrompidos mesmo antes da ortodontia ou mesmo depois pode ser uma boa medida preventiva para se obter o sucesso ortodôntico.

Examinando 51 jovens pertencentes ao estudo longitudinal de desenvolvimento dos terceiros molares, RICHARDSON ${ }^{137}$ (1982) examinou as alterações na região do arco dentário de canino a canino após cinco anos de controle por meio de modelos de gesso e radiografias oblíquas a $60^{\circ}$ para ambos os lados. Como conclusões, relatou que os indivíduos que apresentam os terceiros molares não irrompidos manifestaram apinhamento no início da dentadura permanente, localizado na região anterior e nos molares do que os indivíduos que apresentam os terceiros molares irrompidos completamente. Em média, os indivíduos que apresentam os terceiros molares não irrompidos têm o diâmetro mesiodistal aumentado destes dentes. Observou que há uma tendência do arco bem alinhado na dentadura permanente desenvolver apinhamento na fase adulta. Concluiu que o pressionamento na região posterior e a presença dos terceiros 
molares causam o apinhamento ântero-inferior, entretanto não descartou o envolvimento de outros fatores.

Alguns cuidados devem ser tomados quando os terceiros molares estão não irrompidos, buscando minimizar as alterações na região ântero-inferior. MARTINS; RAMOS $^{92}$, em 1997, afirmaram que a avaliação periodontal (pericoronarites e integridade da crista alveolar por distal dos segundos molares) e da oclusão (interferências oclusais) podem indicar a remoção destes dentes. Concluíram que na pequena parcela da população que apresenta os terceiros molares em condição periodontal, oclusal e ortodôntica favorável de irrupção, o fator "influência no apinhamento ântero-inferior" merece outras soluções que não a simples extração dos terceiros molares.

BISHARA $^{18}$, em 1999, propôs-se a revisar alguns estudos pertinentes ao terceiro molar no contexto ortodôntico. Relatou que o clínico deve se basear em extrair ou não os terceiros molares numa informação científica mais precisa e numa proposta de tratamento mais favorável para cada paciente. Concluiu que a influência dos terceiros molares no alinhamento dos dentes anteriores pode ser controversa, não existindo evidência que estes dentes sejam o único ou o maior fator etiológico das alterações pós-tratamento quanto ao alinhamento dos incisivos.

PROFFIT ${ }^{123}$ (2002) afirmou que o crescimento mandibular tardio talvez seja o principal fator responsável pelo apinhamento ântero-inferior, notadamente nas más oclusões de Classe I e suave Classe III dentária em que os incisivos inferiores mantêm contato próximo aos superiores ou recebem influência direta do lábio inferior.

\subsection{O crescimento mandibular e os terceiros molares não irrompidos}

Os terceiros molares consistem em dentes extremamente importantes para o ortodontista uma vez que todo diagnóstico e plano de tratamento ortodôntico devem ser determinados de acordo com a avaliação de sua presença e posição. Sugeriu- 
se que todo caso ortodôntico só deve ser considerado finalizado até que estes dentes tenham irrompido ou tenham sido removidos ${ }^{135}$. Devendo-se lembrar que o crescimento mandibular e o aumento do espaço retromolar continua a ocorrer até a fase adulta ${ }^{14,55}$. Em contraposição ao que anteriormente se pensava que o crescimento da mandíbula e da maxila se completava aos 16 ou 17 anos de idade $^{127}$.

Em 1930, GOBLIRSCH ${ }^{46}$ comentando sobre os terceiros molares, considerou que se o crescimento dos maxilares for deficiente, não haveria espaço suficiente para o desenvolvimento e irrupção normal destes dentes.

Os tipos primitivos possuíam amplo espaço para o alinhamento dos terceiros molares superiores e inferiores com os outros dentes, havendo, freqüentemente, espaços distais aos mesmos. Nos tipos com menos desenvolvimento dos ossos, as tuberosidades eram menores. Não havia grandes irregularidades nos dentes anteriores, mas existiam restrições de espaço na região posterior. Verificou-se que o tamanho dos dentes pode ser determinado no indivíduo bem antes de cessar o crescimento dos $\operatorname{arcos}^{60}$. A irrupção incompleta dos terceiros molares inferiores consiste em um dos maiores problemas na Odontologia pela sua freqüente ocorrência e suas implicações clínicas. A falha na irrupção completa dos terceiros molares inferiores geralmente associa-se à falta de espaço no arco, entre os segundos molares e o ramo ascendente. O espaço insuficiente foi confirmado por meio dos estudos biométricos de HENRY; MORANT ${ }^{60}$ (1936) que denominaram a distância entre a distal do segundo molar e o limite anterior do ramo, em relação à borda alveolar, como espaço M3. Mediram este espaço em telerradiografias laterais e a linha oclusal foi definida como uma linha que passa pela borda incisal dos incisivos centrais inferiores e a superfície oclusal do segundo molar. A irrupção completa do terceiro molar inferior geralmente define-se por três planos de espaço divergentes. A impacção horizontal e angular está definida pela posição inclinada do terceiro molar contra a face distal do segundo molar, em que a irrupção está impedida (nos sentidos mésio-oblíquo, horizontal e invertido) ou contra o ramo ascendente (posição disto-oblíqua). Estes quatro tipos de disposições podem ser 
considerados como ilustrações representativas da impacção do terceiro molar. $\mathrm{Na}$ grande maioria dos casos, ocorre o posicionamento mésio-oblíquo e como as impacções verticais em jovens são difíceis de serem diferenciadas do retardo de irrupção dentária, estas não foram incluídas neste estudo. Posteriormente, LEDYARD $^{82}$ (1953) e, mais tarde, BJÖRK; JENSEN; PALLING ${ }^{20}$ (1956) também denominaram o espaço da distal do segundo molar à borda anterior do ramo de M3.

Em relação à irrupção dos terceiros molares inferiores, HELLMAN ${ }^{59}$, em 1938, afirmou que a posição ou inclinação dos terceiros molares se altera com a idade, tornando-se mais vertical ou horizontal, sendo que ambas situações se relacionam com a irrupção ou a impacção, respectivamente. Atestou que estas unidades dentárias assumem um aspecto rudimentar e variam imensamente em tamanho e forma. Além disso, devido às tendências evolutivas de diminuição das bases ósseas, mais especificamente envolvendo a redução do espaço da área retromolar para acomodar toda a dentadura permanente, há, portanto, uma freqüente impacção dos terceiros molares. Justificou que uma explicação para isso seria o fato do crescimento dos arcos dentários se completar antes da irrupção dos terceiros molares.

O futuro desaparecimento dos terceiros molares foi protagonizado por ROTHEMBERG ${ }^{148}$ (1945). Atestou que a redução do tamanho dos dentes se produz em função da diminuição do trabalho mastigatório. Essa menor necessidade de trabalho devido aos alimentos mais macios não induzirem aos desgastes interproximais, explicaria a freqüência de retenção dos terceiros molares, principalmente dos dentes de final de série.

Estudando 375 cefalogramas laterais de pacientes com problemas ortodônticos, LEDYARD JR. ${ }^{82}$ (1953) afirmou que o espaço disponível na distal dos segundos molares inferiores até a borda anterior da mandíbula assume grande importância, devendo ser maior do que o diâmetro mesiodistal do terceiro molar a ser irrompido para que este se alinhe no arco normalmente. Entretanto, isto não significa que quando o espaço suficiente está presente, uma normal irrupção dos 
terceiros molares deve ser esperada. Citou que há outros fatores envolvidos com a irrupção destes dentes como: 1- desenvolvimentos radicular e dentário do paciente; 2- posição do molar em relação ao arco inferior e ao segundo molar; 3- direção de movimentação da coroa; 4- reação dos tecidos circundantes a este desenvolvimento. Entretanto, geralmente, uma falta de espaço certamente resulta em sua impacção. Desenvolveu um método para estimativa da probabilidade de impacção ou irrupção do terceiro molar tão logo sua coroa se calcifica.

Para que o ortodontista perceba que realizou o melhor tratamento ortodôntico para um determinado paciente, este deve estar consciente do relacionamento dos terceiros molares com os dentes remanescentes no arco dentário ${ }^{33}$. Os terceiros molares inferiores constituem-se nos dentes mais freqüentemente não irrompidos depois dos terceiros molares superiores ${ }^{4,56}$. A incidência de impacção dos terceiros molares inferiores varia consideravelmente entre as diferentes populações, compreendendo uma porcentagem de $9,5 \%$ a $39 \%{ }^{131}$ Os terceiros molares não irrompidos são provavelmente decorrentes da falta de espaço na área retromolar, crescimento esquelético limitado, irrupção distal da dentição, direção vertical do crescimento condilar, tamanho excessivo da coroa do dente impactado e maturação tardia ${ }^{6}$.

O período de irrupção dos terceiros molares inferiores mostrou consideráveis variações em diferentes populações, compreendendo dos 14 aos 24 anos de idade ${ }^{6,166}$. Apesar da variação racial, outros fatores que influenciam o tempo de irrupção dos terceiros molares podem estar relacionados com o tipo da dieta, grau de utilização do sistema mastigatório, extensão generalizada da atrição dentária e herança genética ${ }^{4,108}$. A predição de posição e irrupção das alterações de posição dos terceiros molares consiste numa questão clínica importante, pois a impacção pode ser benéfica para a ancoragem ortodôntica, próteses fixas ou transplantes. Além disso, extrações dos terceiros molares após a irrupção completa reduz os riscos do procedimento cirúrgico ${ }^{56}$. 
Estabelecendo uma associação entre a falta de espaço para o terceiro molar e sua impacção, BJÖRK; JENSEN; PALLING ${ }^{20}$, em 1956, examinaram 243 casos e se propuseram a determinar os fatores essenciais no crescimento mandibular que se relacionam ao espaço do terceiro molar. Desta forma, indicaram, em casos de impacção, que o espaço distal aos segundos molares do arco alveolar inferior é consideravelmente reduzido em $90 \%$ dos casos. O espaço M3 foi mensurado em cefalogramas laterais pela distância entre a superfície distal do segundo molar e o limite anterior do ramo mandibular, ao nível da linha oclusal no arco dentário inferior. A linha oclusal foi definida a partir do limite anterior da borda incisal dos incisivos centrais inferiores e o centro da superfície oclusal dos segundos molares. Este método objetivou eliminar a influência de qualquer posição mésio ou disto-angular do segundo molar. Nos casos de projeção dupla, o ponto médio foi utilizado. Estimaram o crescimento mandibular em cefalogramas laterais e os três fatores de variação referentes ao desenvolvimento do tamanho e forma mandibular foram relacionados ao espaço do terceiro molar: 1- direção vertical do crescimento condilar como indicado pelo ângulo da base da mandíbula; 2- crescimento insuficiente da mandíbula, em proporção com a quantidade de substância dentária, considerado como uma das causas para a impacção do terceiro molar. O comprimento mandibular reduzido foi referido como a distância do ponto do mento até a cabeça do côndilo; 3- irrupção mais distal dos dentes inferiores determinada pelo grau de inclinação alveolar na mandíbula. A combinação dos três fatores esqueléticos do desenvolvimento mandibular com retardo no desenvolvimento dos terceiros molares contribuiu para $80 \%$ dos casos de impacção bilateral dos terceiros molares. A maturação deficiente da dentição parece ser um quarto fator a ser considerado no prognóstico.

Investigando por meio de um estudo transversal, SHANLEY ${ }^{163}$, em 1962, avaliou três grupos de pacientes para determinar a influência dos terceiros molares inferiores nos dentes ântero-inferiores. Um grupo apresentava terceiros molares irrompidos normalmente; o segundo grupo apresentava terceiros molares não irrompidos e o terceiro grupo apresentava terceiros molares congenitamente ausentes. Concluiu que não houve diferenças significantes nas discrepâncias do 
comprimento do arco dentário ou nos ângulos dos incisivos inferiores em relação ao plano mandibular nos três grupos investigados.

Os terceiros molares são importantes para o ortodontista e o diagnóstico e plano de tratamento não podem ser obtidos sem a determinação de sua presença e posição. Os exames radiográficos dos terceiros molares inferiores em desenvolvimento revelam que existe uma variação considerável no grau de angulação destes dentes de um indivíduo para outro e mesmo entre os lados direito e esquerdo do mesmo paciente ${ }^{135}$. RICHARDSON ${ }^{135}$, em 1970, selecionou 162 crianças do arquivo do estudo longitudinal do desenvolvimento do terceiro molar. Os casos escolhidos foram aqueles em que era possível mensurar a condição do espaço nos modelos, e porque existia calcificação suficiente em pelo menos um terceiro molar para permitir a mensuração de sua angulação. A média de idade dos pacientes da amostra era de 11,1 anos. Modelos de gesso, bem como cefalogramas a $60^{\circ}$ dos lados direito e esquerdo foram obtidos de cada indivíduo. Estas radiografias foram obtidas para fornecer uma visão clara do terceiro molar de cada lado da mandíbula, sem superposição. A metodologia adotada necessitou da obtenção das seguintes mensurações realizadas nas radiografias: 1- o ângulo formado pela superfície oclusal do terceiro molar inferior e o plano mandibular $\left(\mathrm{Y}_{1}\right)$; 2- o ângulo formado pela superfície oclusal do terceiro molar inferior e o plano oclusal $\left(\mathrm{Y}_{2}\right)$; 3- o comprimento da mandíbula medido do gônio ao pogônio $\left(\mathrm{X}_{2}\right)$; 4- o ângulo goníaco medido entre as tangentes da parte inferior da borda distal do ramo e a porção distal da borda inferior do corpo da mandíbula $\left(X_{3}\right)$; 4- o espaço entre o segundo e o terceiro molar mensurado pela menor distância entre a superfície distal do segundo molar e a superfície adjacente do terceiro molar $\left(\mathrm{X}_{4}\right)$; 5 - O tamanho do terceiro molar inferior na sua dimensão mesiodistal mais larga $\left(X_{5}\right)$. Nos modelos, a condição do espaço foi obtida pela subtração entre o comprimento do arco e o tamanho total dos dentes $\left(\mathrm{X}_{1}\right)$. Concluiu-se que: a) em estágios iniciais de calcificação, o terceiro molar inferior em desenvolvimento encontrava-se inclinado mesialmente, formando um ângulo com o plano mandibular de $38^{\circ}$, em média, em uma escala de $11^{\circ}$ a $83^{\circ}$; b) em $82 \%$ dos casos, o terceiro molar inferior distanciavase do segundo molar, em média de $1,2 \mathrm{~mm}$, em uma escala de 0 a $7 \mathrm{~mm}$; c) não 
houve uma relação definida entre o desenvolvimento precoce do terceiro molar inferior em relação ao segundo molar adjacente e também em relação às dimensões dentárias e suas bases apicais.

RICHARDSON $^{133}$, em 1974, objetivando esclarecer alguns problemas associados à irrupção dos terceiros molares, realizou uma análise para avaliar quais eram os fatores influenciadores. Selecionou três grupos da amostra longitudinal de desenvolvimento do terceiro molar: grupo A - composto de 33 jovens que tiveram um ou dois terceiros molares irrompidos mais precocemente; grupo B - composto de 23 pacientes em que os terceiros molares não haviam irrompido sete anos após o início do estudo e que tiveram um ou dois dentes extraídos do arco inferior; grupo C composto de 20 indivíduos em que os terceiros molares inferiores não haviam irrompido após sete anos de observação e que não tiveram extrações no arco inferior. Algumas variáveis foram analisadas para cada um destes grupos: 1- idade ao início do estudo; 2- idade no período da extração, para os grupos A e B; 3angulação do terceiro molar inferior em relação ao plano mandibular, ao início do estudo; 4- quantidade de mudanças na angulação do terceiro molar no início do estudo, nos períodos da irrupção do terceiro molar inferior e do exame; 5quantidade de crescimento da mandíbula no início do estudo e a irrupção dos terceiros molares. As últimas três variáveis foram mensuradas em radiografias obtidas em intervalos anuais. Para as variáveis de número 3 e 4 , realizaram o cefalograma a $60^{\circ}$ e para a quinta variável, utilizaram o cefalograma convencional a $90^{\circ}$. Como conclusões, verificaram alguns fatores associados à irrupção precoce dos terceiros molares: 1) um pequeno grau de angulação inicial no desenvolvimento do terceiro molar com o plano mandibular; 2) uma grande quantidade de mudança nesta angulação; 3) um incremento no crescimento mandibular; e 4) extração dentária do segmento vestibular correspondente, particularmente o molar.

O desenvolvimento do espaço destinado aos terceiros molares é governado por muitos fatores, incluindo a reabsorção óssea da borda anterior do ramo, crescimento posterior da borda anterior do ramo em relação à borda alveolar, deslizamento para anterior da dentição, crescimento em comprimento da mandíbula, 
direção sagital de crescimento mandibular e de irrupção da dentição ${ }^{139}$. Estudos longitudinais mostraram que os terceiros molares geralmente irromperam na idade de 24 anos de idade ${ }^{54}$ ou mais tardiamente ${ }^{184}$. BEHERENTS ${ }^{14}$ (1984) demonstrou que o crescimento facial continua durante a vida adulta até a senilidade. Embora a magnitude das alterações de crescimento avaliada em milímetros por ano seja baixa, o efeito cumulativo com o passar das décadas pode ser surprendentemente grande. FORSBERG; VINGREN; WESSLÉN ${ }^{38}$ (1989) objetivaram testar a validade desta afirmação em dois grupos de jovens adultos com média de idade de 25 anos. Os indivíduos do primeiro grupo apresentaram dentaduras completas incluindo os terceiros molares em boa oclusão. No segundo grupo, todos os terceiros molares foram extraídos devido à falha de irrupção. O comprimento mandibular, morfologia e dimensões do ramo foram também avaliados. Todas as medidas foram realizadas em cefalogramas laterais. A distância Xi-M2 (distância entre os pontos Xi e M2 (segundo molar inferior), paralela ao plano oclusal funcional), apresentou diferença estatisticamente significante nos participantes com dentadura completa quando se comparou com os pacientes que apresentaram os terceiros molares não irrompidos, apresentando valores maiores para esta distância nos homens do que para as mulheres. Entretanto, $50 \%$ dos indivíduos com dentadura completa apresentaram os terceiros molares irrompidos mesmo com a distância Xi-M2 menor que $25 \mathrm{~mm}$. O comprimento mandibular dos homens foi significantemente maior no grupo com dentição completa do que com impacção, e nas mulheres tal diferença não foi registrada. As medidas angulares utilizadas neste estudo não diferiram significantemente entre os grupos.

GOORIS; ÄRTUN; JOONDEPH ${ }^{47}$, em 1990, objetivaram avaliar o contato proximal pós-eruptivo e a inclinação dos terceiros molares inferiores após a extração dos segundos molares e se predições poderiam ser formuladas pelos relacionamentos dentários observados. Desta forma, foram obtidas 95 radiografias panorâmicas no período em que os segundos molares foram extraídos (T1) e na fase final da avaliação (T2). No período T1, a idade dos pacientes variou de nove a 19 anos, com média de idade de 13,3 anos e no período T2, a idade variou de 14 a 22 anos, com média de idade de 18,7 anos. Seis quadrantes foram eliminados 
devido à distorção das radiografias e 44 quadrantes foram excluídos, pois os terceiros molares não haviam chegado ao relacionamento oclusal final no momento do segundo exame radiográfico. Desta forma, 140 quadrantes foram avaliados em 95 ortopantomográficas, 72 quadrantes para o lado direito e 68, para o esquerdo. Um subgrupo de 25 quadrantes de radiografias de pacientes que receberam o mesmo tratamento durante um ano também foi quantificado. Como conclusão, verificaram que $46 \%$ das áreas examinadas tiveram relação de contato dentário satisfatório entre os primeiros e terceiros molares (T2). A impacção dos terceiros molares foi encontrada em $4 \%$ dos quadrantes da subamostra de 25 pacientes tratados. As mensurações da inclinação axial da coroa revelaram que o terceiro molar normalmente irrompe com uma inclinação para mesial. O primeiro molar mostrou somente uma pequena inclinação para distal entre os períodos T1 e T2. A inclinação do germe do terceiro molar no período da extração do segundo molar não foi considerada como um fator predictivo para a posição do terceiro molar.

Em 1991, VENTÄ et al. ${ }^{184}$ objetivaram determinar se as características radiográficas observadas nas panorâmicas obtidas aos 20 anos de idade poderiam predizer a irrupção dos terceiros molares inferiores, por meio de sinais predictíveis da impacção tardia ou irrupção completa destes dentes, aos 26 anos, quando avaliadas numa segunda exposição radiográfica. Como amostra utilizaram 84 terceiros molares inferiores inicialmente não irrompidos ou parcialmente irrompidos de 54 estudantes (16 do gênero masculino e 38 do gênero feminino). Desta forma, um período de observação foi adotado até que a decisão de remoção ou retenção dos terceiros molares inferiores fosse realizada. Os resultados mostraram que os terceiros molares inferiores que realmente irromperam após os 20 anos de idade apresentavam como características: rizogênese completa; envoltório de tecido mole; posição vertical; localização com nível similar ao segundo molar adjacente; presença de espaço suficiente entre o ramo e o segundo molar adjacente. Ao contrário, os dentes que permaneceram não irrompidos aos 26 anos de idade mostraram características iniciais como: formação radicular incompleta; envoltório de tecido ósseo; angulação mesial e localização ao nível cervical do segundo molar adjacente. Concluíram que a radiografia panorâmica obtida aos 20 anos de idade revela 
características às quais uma estimativa de irrupção futura dos terceiros molares inferiores pode ser baseada.

RICHARDSON; RICHARDSON ${ }^{141}$, em 1993, examinaram o curso de desenvolvimento e irrupção dos terceiros molares inferiores em 63 pacientes após a extração dos segundos molares adjacentes. As mudanças na angulação mesiodistal e vestibulolingual foram mensuradas em cefalogramas a $60^{\circ}$ obtidos antes, após três anos das extrações e no final do período de observação. A posição final dos terceiros molares foi avaliada nos modelos ao final do período de observação pela utilização do sistema de escores. Exames radiográficos anuais foram sendo realizados até os terceiros molares serem irrompidos e o período de observação variou de três a 10 anos. O procedimento para obtenção dos cefalogramas a $60^{\circ}$ para os lados esquerdo e direito consistiu na rotação do cefalostato de $90^{\circ}$ até $30^{\circ}$, para a posição lateral esquerda e $150^{\circ}$, para o lado direito. A faixa etária no período da extração variou dos 11 aos 17 anos, com uma média de idade de 14 anos. Todos os terceiros molares inferiores irromperam entre os três aos 10 anos após a extração. Como conclusões, verificaram que: 1- os terceiros molares de tamanho normal podem ser reposicionados no lugar dos segundos molares, na maioria dos casos; 2- a angulação mesiodistal dos terceiros molares antes da extração dos segundos molares não parece influenciar sua posição final; 3- os terceiros molares podem se verticalizar e irromper numa grande variedade de posições mesioangulares; 4- a tendência de alguns terceiros molares inferiores de se inclinar mesialmente e tornarem-se não irrompidos mesioangularmente, com a extração dos segundos molares adjacentes parece estar reduzida; 5 - os terceiros molares tendem a se verticalizar numa dimensão vestibulolingual após os segundos molares serem extraídos; 6- a inclinação lingual dos terceiros molares não parece ser uma contraindicação de extração dos segundos molares; 7- a presença de espaço entre o germe do terceiro molar e o segundo molar adjacente não parece contra-indicar a extração dos segundos molares; 8- os terceiros molares, nos estágios iniciais de desenvolvimento, no momento da extração demoram mais para irromper. A análise de modelos mostrou que $96 \%$ dos terceiros molares inferiores irromperam em posições boas ou aceitáveis. 
KAHL; GERLACH; HILGERS ${ }^{73}$ (1994) conduziram uma pesquisa radiológica retrospectiva em terceiros molares não irrompidos clinicamente assintomáticos. A amostra foi composta de 251 adultos tratados ortodonticamente, sendo que 113 terceiros molares não irrompidos assintomáticos presentes em 58 pacientes avaliados. A avaliação radiográfica revelou contato dos terceiros molares com os segundos molares, reabsorção dos segundos molares superiores e inferiores e redução da altura alveolar na face distal destes últimos dentes, bem como espaços pericoronários aumentados patologicamente nos terceiros molares de ambos os arcos dentários. A comparação da posição sagital do terceiro molar em 52 dentes não irrompidos revelou uma alteração sagital em todos os terceiros molares do póstratamento à fase controle. Os terceiros molares superiores e inferiores rotacionaram para uma posição mais vertical e mostraram um aumento na angulação mesial e distal ou uma alteração na inclinação axial. A falha na predição dos fatores tais como a idade, período de impacção, deficiência de espaço, estágio de desenvolvimento, nível de irrupção e condições ósseas sugerem que os pacientes ortodônticos sejam tratados em intervalos regulares para a avaliação das alterações na condição e posição dos terceiros molares irrompidos e impactados.

HATTAB; RAWASHDEH; FAHMY ${ }^{56}$ (1995) avaliaram a impacção dos terceiros molares em 232 jordanianos (108 do gênero masculino e 124 do gênero feminino) com média de idade de 20,4 anos. Investigaram, por meio de radiografias panorâmicas, o número de terceiros molares não irrompidos, a prevalência de impacção e posição angular, nível de irrupção e desenvolvimento radicular. Os resultados mostraram ausência de dimorfismo sexual quanto a agenesia dos terceiros molares. A impacção dos terceiros molares foi encontrada mais frequentemente na maxila do que na mandíbula. Quanto ao gênero, a proporção de impacção foi semelhante. A posição de impacção mesioangular dos terceiros molares foi verificada em $50 \%$ dos casos, a vertical (40\%), a distoangular (5\%) e a horizontal (5\%), respectivamente. Houve distribuição semelhante de impacção entre os lados direito e esquerdo. Concluíram ainda que não foi verificada assimetria angular entre os lados dos terceiros molares em virtude do alto coeficiente de correlação obtido. 
Num estudo longitudinal, HATTAB $^{54}$ (1997) objetivou determinar radiograficamente as alterações angulares e os níveis de irrupção dos terceiros molares inferiores não irrompidos em jordanianos e árabes durante um período de quatro anos de observação. A amostra consistiu de 36 universitários (19 do gênero masculino e 17 do gênero feminino, com média de idade entre os 18,6 a 20,8 anos), sendo um total de 67 molares avaliados. Como critério da amostra, os participantes deveriam apresentar os terceiros molares inferiores mesialmente não irrompidos, arco dentário inferior completo, com exceção dos terceiros molares, e não deveriam ter sido submetidos ao tratamento ortodôntico. Radiografias panorâmicas foram obtidas ao início do estudo e 4 anos após, sob condições padronizadas. As radiografias foram examinadas quanto ao grau de inclinação e nível de irrupção dos terceiros molares. A posição mesioangular do terceiro molar inferior foi determinada pelo relacionamento sagital com o segundo molar adjacente obtido pelo traçado na radiografia panorâmica. Uma linha foi desenhada através do ponto médio da superfície oclusal e bifurcação dos segundos e terceiros molares inferiores, representando assim os longos eixos destes dentes. O ângulo formado entre as intersecções dos longos eixos forneceu a graduação da inclinação do terceiro molar relativo ao segundo molar. O ângulo de inclinação foi mensurado em graus que variaram de $5^{\circ}$ a $65^{\circ}$, considerando-se os molares horizontalmente não irrompidos quando os valores eram acima de $65^{\circ}$. Para os propósitos deste estudo, o terceiro molar inferior foi considerado impactado quando o trajeto de irrupção era bloqueado pelo dente adjacente, podendo estar não irrompido ou parcialmente irrompido. Os níveis de irrupção dos terceiros molares foram agrupados de acordo com o grau de profundidade em relação à linha cervical do segundo molar adjacente: nível $A$ - a parte mais alta do terceiro molar inferior estava no mesmo nível ou mais alta do que o plano oclusal do segundo molar adjacente; nível B - a parte mais alta do terceiro molar inferior estava abaixo do plano oclusal, porém acima da junção amelocementária (linha cervical) do segundo molar e; nível C - a parte mais alta do terceiro molar esta abaixo da linha cervical do segundo molar inferior. Dentre os terceiros molares inicialmente examinados, $22 \%$ estavam no nível B de irrupção, parcialmente irrompidos; $78 \%$ estavam no nível C (não irrompidos). Durante os quatro anos do período de observação, $42 \%$ dos não irrompidos (nível A) e $62 \%$ dos 
parcialmente irrompidos atingiram o nível do plano oclusal. Concluiu que as discrepâncias bilaterais de posição e irrupção dos terceiros molares não irrompidos são fenômenos imprevisíveis. Além disso, os terceiros molares com menor grau de inclinação inicial assumiram posições mais verticais do que aqueles com maior inclinação, irrompendo por completo quando o paciente apresentou 24 anos de idade. Aproximadamente $1 / 3$ da amostra mostrou assimetria bilateral nas alterações de angulação e movimento eruptivo durante o período de acompanhamento.

HATTAB; ABU ALHAIJA ${ }^{55}$ (1999) investigaram as variáveis nos terceiros molares e dimensões dos arcos dentários de pacientes com terceiros molares inferiores não irrompidos e irrompidos. Radiografias panorâmicas foram obtidas de 134 pacientes com faixa etária média de 19,8 anos (60 do gênero masculino e 74 do gênero feminino) para a avaliação de 213 terceiros molares. Sessenta e nove pacientes apresentaram 101 terceiros molares com impacção para mesial e 65 pacientes com 112 terceiros molares totalmente irrompidos. Para o grupo impactado, somente aqueles com terceiros molares com inclinação mésio-angular foram avaliados. As características radiográficas estudadas foram: a angulação dos dentes; nível de irrupção; desenvolvimento radicular; largura mesiodistal da coroa; espaço retromolar e ângulo goníaco. Concluíram que a variável mais significante associada com a impacção dos terceiros molares consistiu no espaço retromolar insuficiente. Com os resultados encontraram que: (1) O espaço retromolar foi significantemente menor no grupo com impacção do que no grupo com os terceiros molares irrompidos; (2) Significantemente mais terceiros molares teriam irrompido se a relação do espaço retromolar e a largura da coroa apresentassem uma proporção $\geq 1$; (3) Mesmo quando o espaço retromolar era adequado, aproximadamente $17 \%$ dos terceiros molares não irromperam; (4) A maioria dos terceiros molares não irrompidos apresentou rizogênese completa; (5) Poucos pacientes apresentaram assimetria entre os lados direito e esquerdo quanto à impacção ou irrupção dos terceiros molares; e (6) não houve relação entre o tamanho do ângulo goníaco e a irrupção ou impacção dos terceiros molares. 
Investigando sobre a existência dos germes dos terceiros molares em pacientes ortodônticos xantodermas, KAJIl et al. ${ }^{74}$ (2001) avaliaram a relação entre a presença destes dentes e o relacionamento ântero-posterior dos arcos dentários. Para tanto, 306 pacientes (108 homens e 198 mulheres) foram selecionados da clínica de Ortodontia da Universidade de Hokkaido, no Japão. A faixa etária média da amostra era inferior a 15 anos de idade, quando foram inicialmente avaliados. Pacientes apresentando deformidades congênitas como fissura palatina foram excluídos do estudo. Radiografias panorâmicas e telerradiografias foram obtidas ao início da pesquisa para se determinar a presença dos germes dos terceiros molares e o ângulo ANB, respectivamente. Utilizaram esta medida cefalométrica, objetivando classificar as más oclusões baseadas no relacionamento ântero-posterior maxilomandibular dos arcos dentários: Classe I esquelética (ANB de $2^{\circ}$ a $6^{\circ}$ ); Classe II esquelética (ANB maior que $6^{\circ}$ ) e Classe III esquelética (ANB menor que $2^{\circ}$ ). As porcentagens dos pacientes que apresentavam todos os quatro terceiros molares ou apenas um dos quatro dentes foram calculadas. Concluíram que aproximadamente $77 \%$ dos pacientes ortodônticos xantodermas apresentam todos os quatro terceiros molares; a freqüência dos germes dos terceiros molares inferiores é maior que a dos superiores e, finalmente, a porcentagem dos pacientes com Classe II esquelética, apresentando todos os terceiros molares é maior do que nos pacientes com má oclusão de Classe III.

\subsection{Posição e freqüência dos terceiros molares não irrompidos}

Em um trabalho realizado com 3.599 radiografias panorâmicas em jovens norte-americanos, acima de 20 anos obtidas nas Faculdades de Odontologia de Indiana e Oregon, nos EUA, DACHI; HOWELL ${ }^{30}$, em 1961, encontraram uma incidência de $16,7 \%$ de dentes não irrompidos. Os dentes mais freqüentemente não irrompidos apresentaram a seguinte ordem: terceiros molares superiores, terceiros molares inferiores, caninos superiores e pré-molares inferiores. A incidência de impacção dos terceiros molares superiores foi de $21,9 \%$, enquanto que para os inferiores foi de $17,5 \%$. Trinta e sete porcento dos terceiros molares inferiores e $15 \%$ dos terceiros molares superiores apresentaram áreas de radiolucência ao redor 
de suas coroas. Não encontraram dimorfismo sexual na incidência de impacção dos terceiros molares neste trabalho.

Utilizando-se de radiografias panorâmicas de 3.745 pacientes que procuraram atendimento na Clínica de Cirurgia Bucal do Hospital de Harlem, em Nova York, KRAMER; WILLIAMS ${ }^{77}$, em 1970, não encontraram diferenças significantes em relação ao gênero quanto à incidência de impacções na população melanoderma $(18,2 \%)$. Os terceiros molares representaram $94,8 \%$ do total das impacções deste total. Concluíram que os terceiros molares não irrompidos são encontrados na mesma proporção tanto unilateral como bilateralmente, sendo os superiores mais freqüentemente não irrompidos do que os inferiores. Estes resultados surpreenderam muitos cirurgiões que pensavam que a freqüência era maior para os inferiores. Entretanto, os terceiros molares inferiores relacionam-se aos dentes mais difíceis de serem removidos, apresentando mais problemas no pré e pós-operatório, sendo sempre os mais indicados para exodontia pelos clínicos gerais.

MORRIS; JERMAN ${ }^{104}$, em 1971, avaliando radiografias panorâmicas de 5.000 recrutas com média de idade de 19,5 anos da Força Aérea Americana, encontraram uma incidência de pelo menos um terceiro molar não irrompido em $65,6 \%$ das radiografias panorâmicas e $22,3 \%$ de voluntários com os quatro terceiros molares não irrompidos. O estudo obteve ainda uma incidência de 4,36\% de cistos relacionados com os terceiros molares não irrompidos.

Avaliando 4.063 radiografias panorâmicas do Instituto de Odontologia da Universidade de Turku, na Finlândia, AITASALO; LEHTINEN; OKSALA ${ }^{1}$ (1972) obtiveram uma prevalência de $14,1 \%$ de dentes não irrompidos, sendo $76,1 \%$ eram terceiros molares, não havendo diferença significante entre a mandíbula e maxila na incidência de impacção destes dentes. Concluíram que a prevalência de impacção dos terceiros molares diminui conforme aumenta a idade dos pacientes, pois os dentes poderiam ter sido extraídos antes da realização da radiografia panorâmica. 
Examinando 7.886 canadenses, SHAH; BOYD; VAKIL ${ }^{161}$ (1978) concluíram que os terceiros molares são os dentes mais freqüentemente não irrompidos, havendo uma distribuição normal entre a maxila e a mandíbula. Entretanto, afirmaram que há uma maior incidência de impacção para os indivíduos do gênero feminino do que para os do gênero masculino, e ainda encontraram uma distribuição normal entre os lados direito e esquerdo dos arcos dentários.

Três pesquisadores da Universidade da Flórida, ALATTAR; BAUGHMAN; $\mathrm{COLLET}^{5}$, em 1980, examinaram 6.780 radiografias panorâmicas quanto à incidência de patologias e normalidades. Três tipos de aparelhos radiográficos foram utilizados neste trabalho: Panorex; Orthopantomograph e Panelipse. A visualização de quatro estruturas anatômicas de referência foi utilizada para a comparação estatística do valor de diagnóstico dos três filmes: a articulação temporomandibular; a linha oblíqua externa; o forame mentoniano e o canal mandibular. O aparelho Orthopantomograph foi considerado o mais confiável para a visualização das estruturas anatômicas. Primeiramente, a patologia mais comumente encontrada foi a impacção dentária, em segundo lugar, verificaram a presença de raízes residuais e em terceiro lugar, detectaram cistos periapicais ou granulomas. Consideraram a radiografia panorâmica como um recurso complementar aos exames radiográficos intrabucais.

Em 1987, SEWERIN ${ }^{160}$ ressaltou a importância da localização radiográfica da verdadeira posição dos dentes não irrompidos, na correta avaliação do risco de infecção no espaço pericoronário, dentre outras complicações trans-operatórias. Salientou que o exame radiográfico apresenta uma série de propósitos, como a verificação, análise da anatomia, inclinação, relação das estruturas adjacentes e avaliação das complicações. Concluiu que a correta e cuidadosa interpretação das radiografias nos seus vários ângulos auxilia no diagnóstico e prognóstico das intervenções cirúrgicas.

Em 1989, SCHERSTÉN; LYSELL; MADELEINE ${ }^{155}$ estudaram a prevalência de impacção dos terceiros molares em 257 estudantes suecos por meio de radiografias 
panorâmicas e periapicais, com faixa etária de 20 a 39 anos. Não encontraram diferença estatisticamente significante em relação ao gênero quanto à impacção. A freqüência de impacção dos terceiros molares foi maior na mandíbula (66\%) do que na maxila (34\%). Metade dos pacientes tinha os quatro terceiros molares não irrompidos e $10 \%$ dos indivíduos apresentam agenesia nos quatro quadrantes dos terceiros molares. Um ou mais terceiros molares não irrompidos foram encontrados em $33 \%$ dos pacientes.

PETERSON ${ }^{116}$, em 1992, afirmou que a saúde periodontal do segundo molar é mais favorável quando o terceiro molar está totalmente intra-ósseo e quando o paciente é jovem. Ressaltou a importância de se removerem os terceiros molares parcialmente irrompidos para se prevenir a formação de bolsas periodontais profundas e comprometimento do segundo molar por cárie. Em pacientes com mais de 35 anos de idade, recomendou que os dentes não irrompidos devem ser mantidos intactos, a não ser que uma condição patológica seja instalada.

Analisando criteriosamente alguns aspectos na radiografia panorâmica durante o planejamento da cirurgia de um terceiro molar inferior, MARZOLA ${ }^{94}$ (1995), destacou a posição do terceiro molar inferior, a posição do segundo molar adjacente, a relação do terceiro molar com a borda anterior do ramo da mandíbula, a profundidade relativa do terceiro molar inferior retido no osso mandibular, a avaliação da integridade da coroa do terceiro molar e a avaliação das raízes e septo interradicular do terceiro molar. Descreveu e propôs em detalhes uma técnica cirúrgica a ser utilizada na exodontia do terceiro molar inferior.

Um estudo longitudinal foi realizado na Nova Zelândia em relação à impacção dos terceiros molares por KRUGER; THOMSON; KONTHASINGHE ${ }^{79}$ (2001) objetivando descrever a presença e impacção dos terceiros molares aos 18 anos de idade, bem como as mudanças clínicas observadas dos 18 aos 26 anos de idade. Para tanto, obtiveram 81 panorâmicas dos participantes aos 18 anos, não encontrando diferença significante entre os gêneros na proporção dos dentes não irrompidos. Verificaram maior porcentagem de dentes não irrompidos na maxila em 
relação à mandíbula, e de todos os terceiros molares avaliados aos 18 anos, aproximadamente $54,9 \%$ dos dentes que não estavam impactados irromperam aos 26 anos. Desta forma, concluíram que uma impacção aparente na radiografia aos 18 anos não constitui um parâmetro para a remoção profilática dos terceiros molares, na ausência de outras indicações clínicas.

\subsection{As extrações dentárias e a irrupção dos terceiros molares}

Os terceiros molares continuam em seu processo de irrupção, podendo haver uma impacção decorrente do menor crescimento no ramo da mandíbula em função da diminuição dos arcos. LYONS ${ }^{89}$ (1916) assinalou que as más conseqüências gerais da impacção podem estar relacionadas com a paralisia facial, neuralgia, dores de cabeça, epilepsia, otite média, insônia, melancolia e paralisia do arco. Os distúrbios locais podem ser os cistos, reabsorção e deterioração do dente adjacente, infecções agudas e crônicas, celulite, odontalgia, má oclusão e reações inflamatórias nos tecidos moles e duros. Para a eliminação destes problemas, deve-se recorrer à extração do dente envolvido. Enquanto LEVINE $^{84}$, em 1917, afirmou que os terceiros molares não iriam desaparecer dos arcos dentários, mas iriam persistir provavelmente numa situação rudimentar.

Os terceiros molares são talvez os mais interessantes de todos os dentes do arco dentário dos seres humanos. Este fato relaciona-se à grande quantidade de artigos publicados em periódicos, referindo-se a estes dentes. Desta maneira, verifica-se que muitos profissionais ainda continuam se deparando com a questão de extraí-los ou preservá-los. Há uma grande variação da oclusão normal dos dentes em relação aos terceiros molares, sendo invariavelmente anormais na maioria dos casos. Podem estar mal posicionados, não irrompidos, deteriorados ou subdesenvolvidos uma vez que são os últimos dentes a assumirem suas posições nos arcos dentários. Caso haja uma deficiência de desenvolvimento dos arcos, com certeza não haveria espaço suficiente para os dentes irromperem normalmente ${ }^{46}$. 
A diminuição dos arcos constitui-se no resultado do processo de evolução. GOBLIRSCH $^{46}$, em 1930, afirmou que os terceiros molares superiores e inferiores são muito atrasados em irrupção, especialmente entre as "raças superiores" e são evidentemente dentes "decadentes" que eventualmente irão desaparecer por completo. Relatou que parece que os molares, ou melhor, os terceiros molares tendem a se tornar rudimentares nas mais civilizadas raças humanas. Nos caucasianos, estes dentes são muitas vezes menores que os outros molares, entretanto, nos melanodermas, são proporcionais aos outros molares, apresentando três cúspides. Esta diferenciação entre as raças reflete-se na menor porção posterior de espaço destinado à irrupção dos terceiros molares naqueles que são civilizados em virtude da ingestão mais freqüente de alimentos macios e da menor utilização dos arcos durante a mastigação. Atualmente, esta progressiva diminuição dos arcos dentários nos seres humanos não foi provada clinicamente.

Em 1956, BJÖRK ${ }^{20}$ mostrou que o espaço disponível pode ser mensurado na radiografia cefalométrica lateral como a distância entre a borda anterior do ramo e o segundo molar. Concluiu que a impaç̧ão diminui quanto maior a quantidade de espaço disponível.

As dificuldades de irrupção dos terceiros molares inferiores têm levado alguns profissionais a preconizar de modo sistemático a extração de pré-molares para gerar espaço na região posterior dos arcos. Em 1963, HUGGINS ${ }^{62}$ preconizou as extrações de pré-molares para evitar a retenção dos terceiros molares. Entretanto, FANNING $^{35}$ (1964) advertiu que $75 \%$ dos casos com extração dos quatro prémolares apresentaram os terceiros molares irrompidos, mas que $57 \%$ dos casos sem extração tiveram, também, os terceiros molares irrompidos corretamente.

Em 1964, PERLOW ${ }^{115}$ apresentou quatro casos clínicos para suportar sua observação de que com um tratamento apropriado, os terceiros molares iriam se mesializar e verticalizar naturalmente. Acreditou que se os segundos pré-molares ou, em segundo lugar, os primeiros pré-molares fossem extraídos haveria uma 
melhora de $95 \%$ de chance de irrupção na posição dos terceiros molares não irrompidos.

Em 1968, FAUBION ${ }^{36}$ comparou 20 casos de extração de quatro primeiros prémolares com 20 casos pertencentes a um grupo controle sem extrações, objetivando estudar as vantagens das terapia extracionista. Observou que $55 \%$ dos casos de extração de pré-molares têm os terceiros molares irrompidos, enquanto que nos casos sem extração, somente $15 \%$ apresentam os terceiros molares irrompidos. Em casos de discrepância de comprimento do arco, as extrações de pré-molares auxiliam na disponibilidade de espaço para a irrupção dos terceiros molares inferiores, em um número significante de pacientes. A extração do segundo prémolar inferior no lugar do primeiro pré-molar, melhora as probabilidades de irrupção dos terceiros molares ${ }^{142}$. Os casos de ancoragem máxima, que evitam os movimentos mesiais dos primeiros molares inferiores, mesmo se tratados com extrações, não fornecem espaço suplementar no arco para alojar os terceiros molares $^{142}$.

Em 1971, LASKIN ${ }^{81}$ enfatizou a remoção profilática dos terceiros molares inferiores não irrompidos e impactados tão logo seja evidente que estejam em uma posição desfavorável de irrupção, podendo ser determinados radiograficamente, na faixa etária dos 16 aos 17 anos. A remoção destes dentes em pacientes mais velhos poderia ser mais difícil. As complicações que podem surgir com o aparecimento dos terceiros molares inferiores são o desenvolvimento de pericoronarite, reabsorções patológicas, cáries, formação de lesão cística e neoplasmas, como os ameloblastomas e carcinomas, decorrentes dos cistos dentígeros. Discutiu também as indicações da retenção dos terceiros molares não irrompidos. Uma indicação consiste na possibilidade de perda do segundo molar devido a uma restauração extensa, doença periodontal ou cáries. Outra indicação de retenção é em pacientes ortodônticos em que os quatro pré-molares foram removidos e para aqueles em que as extrações dos terceiros molares poderiam reduzir a dentição para um número total de oito dentes. Além disso, ressaltou que o 
ortodontista pode desejar que os terceiros molares funcionem para ancoragem durante o tratamento.

RICKETTS ${ }^{142}$, em 1972, descreveu seu conceito de crescimento mandibular, permitindo a possibilidade do prognóstico precoce da impacção dos terceiros molares desde o estágio de formação de sua cripta. Nas fases iniciais do desenvolvimento, a cripta do terceiro molar inferior encontra-se na superfície do ramo. Discutiu uma técnica que permite a prevenção da impacção do terceiro molar pela simples enucleação do seu germe na idade por volta dos seis ou oito anos. Sugeriu-se que a distância do ponto Xi de RICKETTS ${ }^{142}$ e o aspecto distal dos segundos molares inferiores (M2) medidos em cefalogramas laterais deve ser de pelo menos de $25 \mathrm{~mm}$ na fase adulta para permitir a livre irrupção dos terceiros molares (M3) no arco inferior.

TURLEY $^{180}$ (1974) empreendeu um estudo de previsão da evolução dos terceiros molares e utilizaram a distância da face distal do segundo molar superior a PTV, para a previsão do terceiro molar superior, e a distância da face distal do segundo molar inferior a Xi, para a previsão do terceiro molar inferior. Estudando 74 casos, concluiu que a distância média da distal do segundo molar inferior até o ponto Xi deve estar ao redor de 30mm para permitir a irrupção do terceiro molar inferior em boa oclusão. Propôs uma curva de probabilidade de retenção dos terceiros molares, baseada numa previsão de crescimento arqueal da mandíbula, com uma comparação do crescimento efetivo. Com estas curvas de probabilidade, pode ser possível responder ao questionamento referente ao efeito que tem um espaço suplementar nas probabilidades de irrupção dos terceiros molares. Afirmou que a cada $1 \mathrm{~mm}$ de espaço adicional, há um aumento em $10 \%$ das possibilidades de irrupção do "siso" inferior. Entretanto, a correção do apinhamento ou o movimento lingual dos incisivos inferiores diminui as probabilidades eruptivas dos terceiros molares.

DIERKES ${ }^{33}$, em 1975, avaliou as mudanças que ocorrem com o desenvolvimento do terceiro molar inferior durante os tratamentos ortodônticos com 
e sem extração. Para tanto, utilizou três grupos contendo 20 pacientes cada, sendo um grupo com extração dos primeiros pré-molares; outro com extração de segundos pré-molares e um grupo sem extração. A amostra de 60 pacientes, pertencente ao seu arquivo, era composta de 32 pacientes do gênero masculino e 28 jovens do gênero feminino, com idades entre nove a 16 anos e média de idade de 12,1 anos, ao início do tratamento. Somente pacientes apresentando ambos os terceiros molares inferiores foram selecionados. Os traçados nas radiografias cefalométricas em norma lateral e periapicais foram realizados ao início do tratamento; ao final do período de tratamento ativo e após dois anos do período de tratamento ativo. As seguintes conclusões foram obtidas: 1- não houve correlação estatisticamente significante nas mudanças da inclinação do terceiro molar inferior em relação ao plano mandibular, desde o início do tratamento até dois anos pós-tratamento ativo, em relação ao aumento no comprimento mandibular mensurado do ponto articulare até o pogônio ou como resultado do movimento mesial dos primeiros molares, nos três grupos estudados; 2- Este estudo mostrou que a remoção dos primeiros ou segundos pré-molares auxilia na manutenção do espaço para a irrupção dos terceiros molares do que no grupo sem extração; 3- Houve um número significante de terceiros molares, nos grupos com extração de primeiros e segundos prémolares, que apresentavam espaço suficiente para irrupção do que no grupo sem extração, mas se encontravam suavemente impactados, não podendo irromper. Pesquisas adicionais deveriam ser realizadas, em relação ao reposicionamento cirúrgico dos terceiros molares inferiores, nos casos em que há espaço suficiente para irrupção e ligeira angulação durante a irrupção.

SCHULHOF $^{158}$ (1976) reforçou que existem muitos fatores que envolvem a irrupção dos terceiros molares, incluindo a direção de irrupção, e que a probabilidade de irrupção relaciona-se com o espaço disponível, não se podendo predizer com certeza se vai haver impacção. Além disso, ressaltou que não se pode contar com sua irrupção ao se extrair os primeiros pré-molares inferiores. Comentou que a enucleação dos terceiros molares deve ser implementada nos casos em que houver $50 \%$ de chance de impacção e $10 \%$ de chance de irrupção para uma oclusão normal. Quando os terceiros molares estão parcialmente irrompidos, apresentam 
33\% de chance de causar o apinhamento ântero-inferior e a recidiva ortodôntica, tendo uma grande chance de tê-los removidos casualmente em virtude de outros problemas dentários como a pericoronarite, distúrbios da ATM e cáries.

OLIVE; BASFORD ${ }^{110}$, em 1981, ressaltaram que algumas técnicas atuais para a predição da irrupção ou impacção dos terceiros molares inferiores estão baseadas em medidas do espaço entre o segundo molar e o ramo. Investigaram a confiabilidade e validade das técnicas radiográficas para avaliar este espaço, tais como: telerradiografias laterais, tomografias rotacionais, interproximais e cefalogramas a $60^{\circ}$ em "crânios secos". Foram selecionados 15 "crânios secos" pertencentes ao Departamento de Anatomia e Biologia Oral da Universidade da Austrália, todos apresentando a dentadura inferior completa, com o terceiro molar inferior irrompido. Medições diretas nas mandíbulas desarticuladas foram feitas com compassos precisos para se calcular a largura mesiodistal do terceiro molar inferior, complementando a avaliação dos exames radiográficos. Concluíram que as tomografias rotacionais, as interproximais e os cefalogramas a $60^{\circ}$ superam as telerradiografias laterais quanto à confiabilidade dos resultados intra-examinador e reprodutibilidade das técnicas radiográficas para estimar o espaço disponível entre o segundo molar inferior e o ramo. A reprodutibilidade ineficaz dos cefalogramas laterais é devido às dificuldades em se localizar as estruturas anatômicas. As tomografias rotacionais são as que melhor estimam a quantidade, em largura, de espaço (referente à distância mesiodistal do terceiro molar) mensurado diretamente nas mandíbulas isoladas dos crânios secos, seguindo-se as radiografias interproximais. A utilização da distância do ponto Xi (ponto geométrico do ramo mandibular) até o segundo molar para acessar o espaço para os terceiros molares inferiores não é considerada suficientemente confiável ${ }^{142}$.

Em 1982, TAIT ${ }^{175}$ comparou a angulação das criptas dos terceiros molares inferiores em 100 radiografias laterais oblíquas de jovens entre as idades de 10,1 a 13 anos. Para tanto, utilizou 50 radiografias com segundos molares inferiores presentes e as demais radiografias mostrando arcos em que os segundos molares inferiores decíduos foram extraídos com subseqüente migração mesial dos primeiros 
molares inferiores permanentes. A idade, o gênero, o lado do arco e o estágio de desenvolvimento do terceiro molar inferior foram determinados em cada radiografia. Concluiu que as criptas dos terceiros molares inferiores eram significantemente menos inclinadas quando os segundos molares decíduos foram extraídos precocemente quando comparadas aos casos em que os mesmos dentes decíduos permaneciam presentes. Além disso, afirmou que em nenhum dos pares de radiografias avaliadas houve semelhança de angulação dos terceiros molares, havendo sempre uma diferença angular. Considerou que a assimetria de posição do terceiro molar inferior pode ser normalmente encontrada ao se comparar os lados dos mesmos pacientes nos pares de radiografias oblíquas.

Dentre 2.721 ortopantomográficas avaliadas, TAIT $^{174}$ (1984) comparou a angulação dos terceiros molares inferiores em ambos os quadrantes da mandíbula de 50 panorâmicas de jovens que apresentaram migração mesial dos primeiros molares inferiores permanentes do lado em que houve a extração unilateral do segundo molar inferior decíduo. Estas radiografias obedeceram ao critério de seleção da amostra que cada filme deveria apresentar: A) a cripta de ambos os terceiros molares inferiores nos estágios de desenvolvimento 1,2 e 3 de GRAVELY ${ }^{51}$, 1965; B) em um quadrante, o segundo molar inferior decíduo em posição normal, segundo pré-molar presente mais não irrompido e ausência de apinhamento na região de pré-molares ou movimento mesial dos molares permanentes; C) do outro lado, ausência de segundo molar decíduo inferior, presumivelmente extraído, com perda de espaço destinado ao segundo pré-molar não irrompido. Em 36 ortopantomográficas, verificou-se que o terceiro molar inferior estava menos inclinado do lado da extração, apresentando significância estatística $(p<0,001)$. A distância da migração mesial foi estimada e os resultados mostraram que a migração mesial precoce dos dentes posteriores reduziu a angulação dos terceiros molares inferiores, tornando-os mais verticalizados devido à maior quantidade de espaço para irrupção.

STAGGERS $^{172}$, em 1990, objetivou examinar os resultados do tratamento de casos com segundos molares superiores e inferiores extraídos e comparar com os 
resultados de casos tratados com primeiros pré-molares superiores e inferiores extraídos. Foram avaliados 22 casos com extrações de segundos molares e 22 casos de primeiros pré-molares, superiores e inferiores extraídos em ambos os grupo. Para cada caso, cefalogramas laterais pré e pós-tratamento foram traçados e inúmeros parâmetros cefalométricos foram comparados. Nas radiografias panorâmicas pré e pós-tratamento, as angulações dos terceiros molares superiores e inferiores foram avaliadas. O tempo de tratamento médio, em meses, foi registrado em ambos os grupos. Os dados obtidos de cada grupo foram analisados para serem verificadas as diferenças estatisticamente significantes. Os resultados mostraram que os dois grupos não apresentaram diferenças significantes, ao contrário do que se esperava com as extrações dos segundos molares. A análise dos dados cefalométricos demonstrou somente poucas diferenças estatísticas entre os grupos. No grupo com pré-molares extraídos, os incisivos superiores e inferiores foram mais retraídos, enquanto os primeiros molares superiores e inferiores foram mais protraídos e os lábios inferiores foram mais retraídos do que no grupo dos segundos molares extraídos. Os resultados do perfil facial após a extração dos segundos molares não apresentaram diferenças dos resultados do outro grupo. A avaliação ortopantomográfica das mudanças de angulação dos terceiros molares não foi estatisticamente significante. Em ambos os grupos, os terceiros molares superiores mostraram uma melhora na angulação, enquanto os terceiros molares inferiores mostraram um indesejável aumento na angulação.

A comparação das alterações angulares dos terceiros molares em pacientes tratados ortodonticamente com e sem extrações foi, em 1992, objeto de estudo de STAGGERS; GERMANE; FORSTON ${ }^{173}$. Para tanto, utilizaram radiografias panorâmicas pré e pós-tratamento de 78 pacientes, sendo 45 tratados sem extrações e 33 com extrações dos quatro primeiros pré-molares. Posteriormente, traçaram o longo eixo do terceiro molar e o plano oclusal e realizaram as mensurações angulares. Os resultados demonstraram que não houve diferenças estatisticamente significantes nas angulações dos terceiros molares, antes e após o tratamento, quando comparados os dois grupos. Assim, concluíram que o tratamento ortodôntico com e sem extrações dos pré-molares pode melhorar a 
posição angular intra-óssea dos terceiros molares sem, contudo, garantir que o mesmo irromperá em bom posicionamento.

$\mathrm{Na}$ busca de uma alternativa para o tratamento ortodôntico, JAGER; KABARITY; SINGELMANN ${ }^{64}$, em 1997, estudaram os efeitos da extração precoce dos segundos molares decíduos. Avaliaram 52 pacientes, por meio de análise cefalométrica computadorizada e de radiografias panorâmicas, obtidas no início e no final do tratamento. Ao término do tratamento, os terceiros molares tinham irrompido em apenas três pacientes. Não obstante, em média, observou-se um movimento para mesial dos terceiros molares, ocorreu também uma melhora significante na inclinação axial destes dentes, especialmente no arco superior.

PUTRICK ${ }^{126}$, em 2003, objetivou comparar o número de terceiros molares superiores presentes, entre pacientes apresentando má oclusão de Classe II, tratados ortodonticamente, sem e com extrações de dois pré-molares superiores. Para tanto, foram selecionados 55 pacientes, divididos em dois grupos. O grupo 1, tratado sem extrações, foi constituído de 28 pacientes, com média de idade de 19,03 anos (idade mínima de 14,08 anos e máxima de 23,92 anos) e o grupo 2, tratado com extrações, foi composto de 27 pacientes com média de idade de 19,94 anos (idade mínima de 14,75 anos e máxima de 25,67 anos). Para a verificação do irrompimento em oclusão dos terceiros molares, utilizaram-se modelos de gesso superior e inferior do último controle dos grupos tratados ortodonticamente. Adicionalmente, realizaram-se avaliações das angulações axiais mesiodistais dos terceiros molares superiores, utilizando radiografias ortopantomográficas do último controle com a presença dos terceiros molares bilateralmente. As angulações axiais dos terceiros molares foram medidas em relação às órbitas e às tuberosidades, em ambos os grupos e foram comparadas. Para comparar o número de terceiros molares superiores irrompidos e em função em ambos os grupos foi utilizado o teste do qui-quadrado e, para comparar as angulações dos terceiros molares intergrupos foi utilizado o teste $t$ independente. Os resultados demonstraram que a quantidade de terceiros molares irrompidos e em função foi estatisticamente maior nos casos tratados com extrações dos pré-molares superiores em relação aos casos tratados 
sem extrações e as angulações mesiodistais foram estatisticamente menores e mais favoráveis à irrupção dos mesmos, respectivamente. Portanto, pode-se esperar que o resultado do posicionamento dos terceiros molares superiores na má oclusão de Classe II, quando conduzido com extrações de dois pré-molares, sejam melhores do que quando realizado sem extrações de dois pré-molares superiores.

$\mathrm{KIM}$ et al. ${ }^{76}$, em 2003, propuseram-se a confirmar se o tratamento com extrações de pré-molares associa-se ao movimento mesial dos molares e ao concomitante aumento do espaço para irrupção dos terceiros molares. Além disso, testaram a hipótese de que este tratamento reduz a freqüência de impacção dos terceiros molares. Para tanto, utilizaram telerradiografias laterais, radiografias panorâmicas e periapicais e modelos de estudo realizados antes (T1) e após o tratamento (T2) e no mínimo 10 anos pós-contenção (T3) de 157 pacientes selecionados do arquivo do Departamento de Ortodontia da Universidade de Washington (Seattle). O tratamento de 105 pacientes envolveu extrações de quatro pré-molares, sendo os demais 52 casos tratados sem extrações. Estes pacientes representaram os casos com e sem extração da amostra que tiveram pelo menos um terceiro molar nos períodos T1 ou T2 e que evidenciaram irrupção completa ou fechamento do ápice radicular nos períodos T2 ou T3. Testes t de Student mostraram valores mais altos para a impacção dos terceiros molares, menor movimento mesial dos molares do período T1 para o T2 e menor espaço retromolar no período T2 em ambos os arcos dos pacientes que não foram submetidos à extração do que nos pacientes com extração. Similarmente, o movimento do molar foi mais mesial de T1 a T2 na maxila e na mandíbula e o espaço retromolar foi maior em ambos os arcos dos pacientes com irrupção do que nos casos com impacção dos terceiros molares. Os resultados sugeriram que a terapia com extrações de prémolares reduz a freqüência de impacção dos terceiros molares devido ao aumento do espaço para sua irrupção e, concomitantente, movimento mesial dos molares durante o fechamento de espaço. 


\subsection{A Classe II, subdivisão}

A má oclusão de Classe II pode ocorrer devido a uma protrusão maxilar ou uma retrusão mandibular ou combinação de ambas estas características. Entretanto, algumas vezes, o complexo maxilomandibular pode estar bem relacionado e a Classe II resulta de uma má posição dos dentes em suas bases esqueléticas, estando os dentes superiores vestibularizados e os inferiores lingualizados em suas respectivas bases ósseas, ou uma combinação de ambos os $\operatorname{arcos}^{28,29,123,185}$. Enquanto que a Classe II, subdivisão pode ser conseqüente, primeiramente, da posição mais distal do molar inferior do lado da Classe $\|^{3,65,145}$, ou secundariamente, da posição mais mesial do molar superior deste mesmo lado ${ }^{65}$.

ANGLE ${ }^{8}$, em 1907, classificou a má oclusão de Classe II unilateral como sendo um caso de subdivisão. Além disso, assegurou, mais especificamente, que a Classe II unilateral, ou subdivisão, decorria da irrupção distal do primeiro molar inferior em relação ao primeiro molar superior do lado da Classe II.

Em 1961, LUNDSTRÖM ${ }^{88}$ afirmou que a subdvisão na má oclusão de Classe II de Angle pode ser ocasionada em parte por uma orientação assimétrica do arco dentário superior, onde a mandíbula não mostra assimetria correspondente. Realizou uma revisão de literatura completa dos fatores etiológicos das assimetrias e explicou que as diferenças genéticas são devido às variações dos gametas e que esta combinação rege o desenvolvimento do indivíduo. Examinando se os dois lados do corpo eram geneticamente programados para serem idênticos, verificou que as assimetrias apresentavam uma natureza secundária, pois se desenvolvem de uma simetria bilateral original alterada em resposta às demandas ambientais funcionais.

Baseando-se em três casos de má oclusão de Classe II, subdivisão com etiologia e tratamento distintos, WERTZ ${ }^{185}$, em 1975, relatou a dificuldade em se diagnosticar e tratar pacientes com Classe II unilateral devido à sua origem multifatorial. Salientou a importância em verificar se a origem da assimetria é dentária ou esquelética. Além disso, comentou que tanto para a Classe II como para 
a Classe III, subdivisão, a sínfise encontra-se desviada para o menor lado da mandíbula em relação à linha média facial, havendo também desvio mandibular. Nos casos de discrepância severa do crescimento mandibular, necessitava-se de uma correção cirúrgica que dependia da quantidade de distorção facial presente. Nas assimetrias dentárias, os segmentos dos arcos dentários destes pacientes devem ser identificados individualmente para o estabelecimento do correto plano de tratamento. Nestes casos, utiliza-se um dispositivo como um dos métodos de determinação da assimetria dentária em modelos de estudo. Para a sua aferição, tem-se como parâmetro a rafe palatina mediana como eixo de simetria, transferindose para o modelo inferior, em oclusão. Nos modelos superior e inferior, traçam-se duas perpendiculares a esta linha palatina mediana, ou seja, uma passando pela distal do molar localizado mais posteriormente no arco dentário e a outra, pelos prémolares. Desta forma, a posição ântero-posterior dos dentes em cada um dos quatro quadrantes, pode ser avaliada, assim como o segmento responsável pela relação ântero-posterior incorreta. Enfatizou a raridade em se encontrar qualquer magnitude de desarmonia esquelética, nestes casos, concluindo que devem ser diagnosticados e tratados, baseando-se no problema individual específico e evitando o emprego do mesmo método de tratamento para todos os casos.

Utilizando radiografias submentonianas e póstero-anteriores, WILLIAMSON; SIMMONS ${ }^{188}$, em 1979, estudaram a assimetria mandibular relacionada à dor e à disfunção. Foram radiografados 53 pacientes com má oclusão pré-tratamento ortodôntico, sendo 27 do gênero feminino e 26 do gênero masculino, com média de idade de 14,2 anos, com a mandíbula posicionada em relação cêntrica. As diferenças entre os lados direito e esquerdo da mandíbula foram mensuradas nas duas normas radiográficas. O relacionamento dentário foi observado nos modelos para conferir se a relação de má oclusão de Classe II era mais acentuada no lado mais curto da mandíbula. A quantidade de dor pré-tratamento durante a palpação muscular foi correlacionada com o grau de assimetria encontrada. Nenhuma correlação estatisticamente significante foi demonstrada entre a assimetria mandibular e a sensibilidade muscular. Os resultados demonstraram que a má oclusão de Classe II de molar e de canino pode ser mais difícil de ser corrigida de 
um lado do que do outro, caso não haja uma compensação da posição da fossa glenóide ou dos dentes superiores. Verificaram que a maioria dos casos da amostra apresentava assimetria, devendo o clínico estar ciente da sua presença em todos os três planos de espaço quando se planeja previamente o tratamento.

Em 1981, WILLIAMSON ${ }^{187}$ definiu a assimetria mandibular como sendo a diferença entre o tamanho e a forma dos dois lados da mandíbula, podendo ocorrer no plano frontal, no horizontal (basilar), ou em ambos, e ser refletida no plano sagital. Como a posição do côndilo em relação cêntrica influencia a avaliação da desarmonia esquelética, deve-se sempre diagnosticar e finalizar os casos nesta posição. Para se evidenciar alguma assimetria mandibular, deve-se recorrer às radiografias frontais e submentonianas, sempre as realizando em relação cêntrica. Considerou que a assimetria sempre vem acompanhada de uma má oclusão como a Classe II, subdivisão ou uma Classe II bilateral, apresentando menor desenvolvimento mandibular do lado mais severo. Concluiu que ao se adotar o conceito de relação cêntrica para estes casos, o arco superior deve ser sempre planejado com ancoragem máxima, no lado deficiente.

Mais especificamente, a assimetria mandibular, em observações clínicas e radiográficas, resulta em um crescimento acelerado do côndilo mandibular de um lado ou o decréscimo do crescimento do lado oposto. TALLENTS et al. ${ }^{177}$, em 1991, comentaram que a assimetria mandibular geralmente relaciona-se a uma hiperplasia condilar unilateral associada a um crescimento acelerado. Comentaram que as conseqüências das assimetrias mandibulares poderiam ser a mordida aberta, o desvio da linha média mandibular em direção contrária ao maior lado, a inclinação do plano oclusal e a mordida cruzada do lado mais curto. As alterações faciais mais comuns são o desvio do mento, em sentido contrário ao lado mais longo ou proeminência ou achatamento da região goníaca. Concluíram que o ângulo goníaco geralmente se encontra mais agudo no lado mais comprido.

Em 1995, JANSON; JUNQUEIRA; DAINESI ${ }^{70}$ discutiram as implicações da assimetria dentária no diagnóstico e plano de tratamento ortodôntico. Descreveram 
um caso clínico de má oclusão de Classe II, divisão 1 , subdivisão com suave apinhamento superior e inferior, desvio de linha média inferior para a direita e suave protrusão labial. A paciente foi tratada com extrações de dois pré-molares superiores e um pré-molar inferior, do lado da Classe I. Os resultados demonstraram que a correção de casos com extrações assimétricas permitem a obtenção de uma relação de Classe I, de caninos, com ótimo relacionamento dos dentes anteriores e coincidência das linhas médias dentárias. Uma guia anterior imediata e um excelente perfil facial foram também obtidos, comprovando a eficiência desta opção de tratamento, nestes casos.

Em 1998, JANSON ${ }^{65}$ avaliou tridimensionalmente as assimetrias dentoesqueléticas das más oclusões de Classe II, subdivisão por meio de radiografias submentonianas, póstero-anteriores e oblíquas corrigidas. Objetivou investigar a presença de assimetrias dentárias e/ou esqueléticas entre 30 pacientes com oclusão normal e 30 jovens com más oclusões de Classe II, subdivisão. A amostra constava de pacientes de ambos os gêneros, com média de idade de 15,76 anos, para o grupo de Classe II, subdivisão e 22,42 anos, para o grupo de oclusão normal, sendo que todos apresentavam os dentes permanentes até os primeiros molares. Na radiografia submentoniana, avaliou-se a assimetria, medindo-se a diferença relativa na posição espacial de pontos dentários e esqueléticos nas dimensões ântero-posterior e transversa, determinadas pelo sistema de coordenadas, representando a mandíbula, o assoalho craniano, o complexo zigomaticomaxilar e os dentes inferiores e superiores. As variáveis foram analisadas pelos testes t e pela análise de regressão logística de multivariáveis. Os resultados demonstraram que a principal diferença entre a má oclusão de Classe II, subdivisão e a oclusão normal consistia numa posição mais distal do primeiro molar inferior do lado da Classe II, em uma mandíbula com assimetria subclínica e sem assimetria de posição. Uma diferença secundária entre os dois grupos consistiu na posição mais mesial do primeiro molar superior, no lado da Classe II. De acordo com estes resultados, a linha média dentária inferior também apresentou um desvio mais freqüente para o lado da Classe II, do que a linha média dentária superior, no sentido oposto, conforme evidenciado na avaliação bidimensional da radiografia 
frontal. Cefalometricamente, os arcos dentários nos casos de má oclusão de Classe II, subdivisão, apresentaram uma maior assimetria do que os de oclusão normal.

Ainda neste ano, $\operatorname{LEGAN}^{83}$ afirmou que o diagnóstico das assimetrias dentofaciais, a história médica e os exames clínico, radiográfico e de modelos de estudo tornam-se necessários para se determinar a extensão do envolvimento do tecido mole, dos componentes esquelético e dentário, além do aspecto funcional. Comentou também que o exame clínico deve incluir uma análise intrabucal com a avaliação dos dentes e das linhas médias faciais, além da detecção de disfunção temporomandibular. Devendo-se identificar também a presença de alteração do plano oclusal como resultado do aumento ou diminuição unilateral do comprimento do côndilo ou ramo mandibular. O exame facial, pelas vistas frontal e lateral, deve ser conduzido para avaliar as assimetrias na morfologia facial e analisar a posição natural da cabeça. A palpação da maxila e do osso temporal, que suportam a fossa glenóide, podem estar em diferentes níveis em cada lado da cabeça. A avaliação do plano oclusal pode ser diretamente visualizada ao solicitar que o paciente morda uma espátula abaixadora de língua, posicionada horizontalmente, para se determinar seu relacionamento com o plano interpupilar. Ainda quanto ao aspecto frontal, considerou que a vista inferior da mandíbula ou a análise da radiografia submentoniana, auxilia na determinação da extensão da assimetria mandibular em relação ao resto da face. Concluiu que as assimetrias esqueléticas verticais associadas às mordidas abertas unilaterais progressivas podem ser resultantes da hiperplasia condilar ou neoplasia.

Uma confusão ainda persiste na comunidade ortodôntica a respeito do significado de subdivisão no sistema de classificação de ANGLE ${ }^{8}$. SIEGEL ${ }^{168}$ (2002) se propôs a questionar aos educadores da área de Ortodontia nos EUA a determinar seus pontos de vista quanto ao significado de subdivisão e certificar o critério em que se baseiam. Cinquenta e sete entrevistas foram enviadas aos chefes de Departamento nos EUA, perguntando-os a definição ensinada em seus programas de residência e somente 34 questionários retornaram. Vinte e duas respostas basearam-se no conceito que subdivisão referia-se ao lado de Classe II, oito 
respostas foram relacionadas ao lado de Classe I e três respostas não apresentaram alguma opinião e uma resposta indicou que os professores daquele departamento não entraram num consenso quanto ao significado. Embora a crença predomine que a subdivisão relaciona-se ao lado em que o molar apresenta a má oclusão, a comunidade ortodôntica não tem uma classificação consistente, sendo necessário estabelecer um padrão a ser seguido.

JANSON et al. ${ }^{71}$ (2003) objetivaram demonstrar e discutir as características da Classe II, subdivisão por meio do tratamento ortopédico e ortodôntico. Para tanto, apresentaram o diagnóstico e plano de tratamento de três casos distintos: o primeiro caso ( 15 anos e 5 meses) foi classificado como uma Classe II, subdivisão direita, com linha média dentária superior coincidente com a linha média facial e desvio da linha média dentária inferior para o lado da Classe II. Como o perfil do paciente permitia retração dos dentes anteriores, empregou-se o tratamento com extrações de dois pré-molares superiores e um pré-molar inferior do lado da Classe I. O segundo caso apresentava uma simetria frontal, $6 \mathrm{~mm}$ de sobressaliência, $6 \mathrm{~mm}$ de sobremordida, Classe II, subdivisão completa do lado direito e Classe I do lado esquerdo. Como o paciente estava numa idade precoce (9 anos e 4 meses) realizou-se o tratamento ortopédico com 0 aparelho guia de irrupção ${ }^{29}$ para se corrigir os trespasses horizontal e vertical e o suave apinhamento dentário com a terapêutica conservadora. $O$ terceiro caso (17 anos e 01 mês) apresentava uma Classe II, subdivisão esquerda devido a um desvio da linha média dentária superior em sentido contrário ao lado da Classe II e coincidência da linha média dentária inferior em relação ao plano sagital mediano. O tratamento ortodôntico com extração de um pré-molar superior do lado da Classe II foi realizado para se corrigir a discrepância sagital e o desvio de linha média. Nos casos com extração de prémolares, recorreu-se ao uso de ancoragem extrabucal até se chegar à relação de caninos em Classe I. Além disso, utilizaram-se elásticos intermaxilares para se finalizar o tratamento com coincidência das linhas médias dentárias superior e inferior. Em todos os casos apresentados, objetivou-se a harmonia do perfil facial e oclusão funcional satisfatória ao final do tratamento. 


\subsection{Relação entre a Classe II, subdivisão e a assimetria}

Numa observação cuidadosa, podem-se verificar alguns graus de assimetria em todas as faces. Embora algumas destas assimetrias sejam principalmente encontradas nos tecidos moles, contribuições esqueléticas podem estar presentes. O relacionamento oclusal assimétrico pode ser resultante de arcos intrinsecamente assimétricos ou de um relacionamento esquelético assimétrico maxilomandibular ${ }^{78}$. Deve-se determinar se a origem dos fatores, que causam a assimetria, consiste num problema dentoalveolar ou esquelético ou combinação de ambos ${ }^{128}$.

Com o propósito de investigar se existe uma diferença lateral sistemática entre os lados direito e esquerdo do arco superior, HUNTER ${ }^{63}$, em 1953, afirmou que a simetria maxilomandibular seria normal e sugeriu que a assimetria lateral associa-se à má formação de um dos arcos dentários. A amostra foi selecionada aleatoriamente seguindo alguns critérios: os arcos não deveriam apresentar mutilações, hipoplasia do esmalte, restaurações e irrupção insuficiente. Para tanto, traçou 93 modelos de jovens do gênero masculino com 13 anos de idade, utilizando projeções ortogonais paralelas ao plano oclusal dos arcos dentários. Para cada traçado, quatro medidas foram obtidas - as distâncias em milímetros da rafe mediana até o ponto da cúspide mesiolingual de cada primeiro molar e da rafe até a cúspide lingual dos primeiros pré-molares. Concluiu que nenhuma diferença sistemática pode ser demonstrada em ambos os lados.

De acordo com BURSTONE ${ }^{25}$, em 1979, a assimetria ocorre mais freqüentemente que a simetria, sendo seu diagnóstico de suma importância no planejamento. Afirmou que a maioria das discrepâncias de linha média é causada pela assimetria esquelética e muitas vezes este fator passa despercebido no plano de tratamento, provocando dificuldades na finalização dos casos. Tais assimetrias devem ser analisadas em quadrantes para que se planeje uma mecânica assimétrica detalhada, visando a correção da linha média. Além disso, considerou que, no início do tratamento, deve ser realizada a detecção de inclinações indesejáveis do plano oclusal, na vista frontal. Durante o tratamento, deve-se controlar a intrusão e a extrusão, para manter o plano oclusal nivelado corretamente. 
Deve-se evitar a utilização de elásticos de Classe II de um lado, de Classe III do outro e elástico cruzado anterior, pois provocam inclinações indesejáveis do plano oclusal esteticamente desfavoráveis. Nas assimetrias esqueléticas, as linhas médias da maxila e da mandíbula não coincidem, constituindo uma discrepância de linha média das bases apicais. As extrações assimétricas com movimentações de corpo de um lado e inclinações do outro se constituem recursos empregados na mecânica assimétrica com variação da perda de ancoragem em cada lado. Lembrou que se deve utilizar o mínimo possível elásticos unilaterais, uma vez que provocam efeitos colaterais no plano oclusal. Os oclusogramas podem ser utilizados no diagnóstico inicial dos casos, solucionando o problema de forma adequada e possibilitando um correto planejamento da mecânica.

Em 1981, WILLIAMSON ${ }^{187}$ definiu a assimetria mandibular como sendo a diferença entre o tamanho e a forma dos dois lados da mandíbula, podendo ocorrer no plano frontal, no horizontal (basilar), ou em ambos, e ser refletida no plano sagital. Como a posição do côndilo em relação cêntrica influencia a avaliação da desarmonia esquelética, deve-se sempre diagnosticar e finalizar os casos nesta posição. Para se evidenciar alguma assimetria mandibular, deve-se recorrer às radiografias frontais e submentonianas, sempre as realizando em relação cêntrica. Considerou que a assimetria sempre vem acompanhada de uma má oclusão como a Classe II, subdivisão ou uma Classe II bilateral, apresentando menor desenvolvimento mandibular do lado mais severo. Concluiu que ao se adotar o conceito de relação cêntrica para estes casos, o arco superior deve ser sempre planejado com ancoragem máxima, no lado deficiente.

Em 1987, MONGINI; SCHMID ${ }^{103}$ utilizaram uma amostra de 11 pacientes em crescimento com uma assimetria mandibular e um desvio do mento, mostrando em todos os casos uma má oclusão com deslocamento mandibular lateral em idade precoce. Radiografias póstero-anteriores, laterais oblíquas, telerradiografias e transcranianas da ATM foram obtidas em máxima intercuspidação habitual, objetivando investigar se algumas assimetrias mandibulares eram adaptações do deslocamento mandibular durante o crescimento. Nas radiografias póstero- 
anteriores, sete pontos foram selecionados para definir as áreas mandibular, craniana superior e craniomandibular, bilateralmente. A posição do mais alto ponto condilar dentro da fossa glenóide foi digitada e avaliada. Os dados radiográficos foram obtidos e analisados novamente após a instalação dos aparelhos funcionais e ao final de um período de observação de 37,6 meses. Radiografias controle foram obtidas com intervalos de seis a 12 meses, constatando-se, após o período de observação, uma melhora significante da assimetria mandibular em nove dos onze pacientes devido ao crescimento compensatório da mandíbula e do côndilo no lado afetado decorrente do deslocamento mandibular. Restabeleceram a normalização do padrão de crescimento por meio da terapia ortopédica. O avanço mandibular promoveu um tensionamento dos músculos temporal e pterigóideo lateral, ocorrendo, conseqüentemente, uma remodelação óssea na região condilar e da fossa glenóide. Verificaram que dos 11 casos tratados, nove apresentaram uma mandíbula mais simétrica devido ao crescimento compensatório mandibular e condilar no lado que foi afetado devido ao deslocamento mandibular. Concluíram, portanto, que tais assimetrias devem ser tratadas pelo restabelecimento do padrão de crescimento normal.

Objetivando investigar a presença de diferenças significantes em relação às assimetrias faciais e dos arcos dentários, ALAVI; BEGOLE; SCHNEIDER ${ }^{3}$, em 1988, desenvolveram um estudo entre pacientes apresentando más oclusões de Classe II, subdivisão e com oclusão normal. Cada grupo constava de 28 jovens, com média de idade de 17,1 anos, apresentando a dentição permanente até os primeiros molares. As medidas lineares foram obtidas nas telerradiografias, nas radiografias póstero-anteriores e nos modelos de estudo, enquanto as medidas específicas foram agrupadas para produzir vários índices de assimetria. Como método estatístico, utilizaram uma análise discriminante multivariada e verificaram que a assimetria ântero-posterior das más oclusões de Classe II, subdivisão devia-se principalmente à posição mais distal do molar inferior, do lado da Classe II. Não foi possível determinar se a posição do molar inferior era devido a uma assimetria esquelética ou dentoalveolar. Além disso, verificaram uma contribuição secundária da assimetria na região dentoalveolar da maxila. 
SLAVICEK ${ }^{171}$, em 1988, afirmou que há uma grande quantidade de casos assimétricos e que seu diagnóstico apresenta suma importância. Quando se inicia precocemente um caso assimétrico esquelético, tem-se a oportunidade de conduzílo simetricamente. Quando se inicia o tratamento tardiamente, deve-se estar consciente de que a terapêutica deve ser assimétrica. $O$ complexo temporomandibular direito e esquerdo dos pacientes eram diferentes, verificando-se que um grande número de casos parece ser assimétrico. Nos casos que apresentam assimetria clínica, deve-se olhar o espaço aéreo faríngeo e a abertura nasal para ver se o lado direito e esquerdo são diferentes, avaliando-se sempre as linhas médias para a detecção de possíveis desvios. Algumas assimetrias podem ser vistas pelo exame radiográfico, quando os condutos auditivos não estão alinhados, ou quando se vê a diferença de altura do ramo e um plano oclusal oblíquo. Em alguns casos as assimetrias são verificadas em relação às diferenças entre os lados direito e esquerdo, na radiografia frontal. Finalmente, concluiu que é necessário estar ciente da presença da assimetria, especialmente a do movimento articular para se fazer um diagnóstico funcional de todos os casos assimétricos, especialmente os mais severos.

Em 1991, PONYI; SZABÓ; NYILASI ${ }^{120}$ buscaram elucidar se havia diferenças entre os lados direito e esquerdo de 18 medidas mandibulares de crânios europeus, de ambos os gêneros, pertencentes aos séculos X e XII, que estavam soterrados no sudeste húngaro. Encontraram uma diferença estatisticamente significante apenas para a menor dimensão sagital do ramo mandibular, nos dois gêneros. Concluíram que a assimetria dos lados esquerdo e direito foi encontrada entre as dimensões mandibulares medidas individualmente em 41,4\% dos crânios masculinos e 40,4\% dos crânios femininos.

Uma amostra longitudinal de jovens com 6, 9, 12, 14 e 16 anos de idade, pertencente ao Centro de Crescimento de Burlington, Ontário, Canadá foi avaliada por MELNIK ${ }^{98}$, em 1992. Este autor analisou a assimetria mandibular e as medidas do ângulo goníaco de ambos os lados, de acordo com o gênero e a idade, por meio da comparação das diferenças obtidas entre os lados direito e esquerdo, nas 
radiografias oblíquas a $45^{\circ}$. Os resultados demonstraram que as assimetrias eram comuns em todas as idades. Um maior comprimento mandibular no lado direito, manifestando-se aos 12 anos no gênero feminino e somente aos 16 anos, no gênero masculino, idade em que cinco a $10 \%$ das jovens apresentavam assimetrias maiores do que $5 \mathrm{~mm}$. Embora o gênero masculino tenha demonstrado uma maior assimetria mandibular, apresentando maior comprimento em idades mais precoces, após os 14 anos não houve mais diferenças entre os gêneros. De modo contrário, diferenças significantes não existiram entre os ângulos goníacos dos lados direito e esquerdo, em relação ao gênero e à idade da amostra estudada.

Utilizando-se radiografias submentonianas, ROSE et al. ${ }^{145}$, em 1994, compararam a simetria mandibular de 58 pacientes. Um grupo experimental de 28 pacientes com más oclusões de Classe II, subdivisão, apresentando média de idade de 28,4 anos, foi comparado a um grupo controle de 30 pacientes com más oclusões de Classe I, com média de idade de 24,9 anos. Quarenta e quatro pacientes eram do gênero feminino e 14 do gênero masculino. A simetria foi avaliada medindo-se em radiografias submentonianas, a diferença espacial relativa de pontos mandibulares nas dimensões ântero-posterior e transversa, determinadas pelos sistemas de coordenadas que representavam a mandíbula, o assoalho craniano e os dentes inferiores. Este trabalho limitou-se somente ao estudo da mandíbula, uma vez que as radiografias submentonianas não são específicas para a análise dos pontos maxilares. Somente aquelas variáveis que representavam a diferença ântero-posterior entre as posições dos molares inferiores direito e esquerdo demonstraram diferença estatisticamente significante entre os grupos. O primeiro molar inferior, quando avaliado em relação à base craniana ou à própria mandíbula, estava localizado mais posteriormente no lado da Classe II, nas más oclusões com subdivisão, em uma mandíbula que não exibia nenhuma assimetria. Qualquer diferença encontrada na assimetria mandibular não excluiu a possibilidade da presença de assimetria dentoalveolar ou esquelética no arco superior contribuir para as más oclusões com subdivisão. Concluíram que a mandíbula na Classe II, subdivisão não exibe uma posição esquelética anormal nem mesmo assimetria esquelética, sendo esta má oclusão decorrente das assimetrias dentárias. 
Em 1994, MARTINS de ARAÚJO; SCHIRMER; ALMEIDA ${ }^{93}$ avaliaram as assimetrias esqueléticas e dentárias em 30 pacientes com média de idade de 11,6 anos, apresentando Classe II, divisão 1, subdivisão. Utilizaram radiografias pósteroanteriores para verificar a presença de assimetria entre os lados de Classe I e de Classe II, divisão 1 , subdivisão, além de modelos de estudo para se determinar a freqüência destas assimetrias. Nove triângulos bilaterais foram demarcados nos traçados cefalométricos para descrever o complexo craniodentofacial. Calculou-se a área de cada triângulo, nas radiografias e a freqüência das assimetrias ânteroposterior e transversa, nos modelos. Os resultados não demonstraram diferenças estatisticamente significantes entre os lados de Classe I e II, nas radiografias, entretanto, a freqüência de assimetrias nos modelos foi estatisticamente significante ao nível de $1 \%$, sendo que o arco inferior apresentou maior assimetria que o superior. Estas assimetrias foram mais evidentes no plano ântero-posterior do que no transverso e, nos arcos inferiores, do que nos superiores. Concluíram que as más oclusões de Classe II, divisão 1, subdivisão são caracterizadas por desvios dentários e não por displasias esqueléticas, no plano frontal.

Em 1995, O'BYRN et al. ${ }^{107}$ buscaram determinar se a simetria mandibular em adultos com mordida cruzada posterior unilateral era diferente daquela de adultos com más oclusões de Classe I, não tratadas. Trinta adultos, acima de 18 anos, com mordida cruzada posterior unilateral foram comparados com 30 adultos com más oclusões de Classe I. Radiografias submentonianas foram obtidas para se avaliar as simetrias esquelética e dentária, enquanto as tomografias horizontais corrigidas serviram para avaliar a posição condilar dentro da fossa glenóide. Em relação ao sistema de coordenadas mandibulares, o primeiro molar inferior, do lado da mordida cruzada, apresentava-se mais lateral e distalmente, em comparação com o do lado oposto. Esqueleticamente, a mandíbula não demonstrou assimetria. A mandíbula apresentou-se rotacionada em relação ao assoalho craniano, de forma que o côndilo do lado da mordida cruzada estava posicionado posteriormente em relação ao lado oposto. Concluiu-se que havia uma posição posterior relativa da fossa glenóide, uma vez que não se observou nenhuma assimetria mandibular esquelética ou deslocamento condilar dentro da fossa, como evidenciado nas tomografias corrigidas 
no grupo com mordida cruzada, quando comparadas com as do grupo de Classe I. Os autores questionaram se seria correto corrigir mordidas cruzadas posteriores unilaterais em adultos apenas ortodonticamente, com a movimentação dentária, considerando-se que a remodelação óssea da fossa glenóide já poderia ter ocorrido. Concluíram que as adaptações tanto na posição mandibular relativa ao sistema de coordenadas do assoalho craniano, como na dentadura, em relação ao sistema de coordenadas mandibulares, existem em adultos com mordida cruzada posterior não tratada. Com a correção do problema oclusal, há um aumento da possibilidade destas alterações ocorrerem dentro da fossa glenóide. As mudanças suaves da posição condilar relacionam-se com a capacidade adaptativa de alguns pacientes em tolerar o desconforto e a dor.

SEVERT; PROFFIT ${ }^{159}$, em 1997, avaliaram a prevalência de assimetria facial em uma população com deformidades dentofaciais na Universidade da Carolina do Norte. Avaliando 1.460 pacientes, detectaram que a assimetria facial clinicamente aparente estava presente em 495 pacientes, totalizando $34 \%$ da amostra. Quando presente, a assimetria facial afetava a porção superior da face em apenas 23 casos (5\%), o terço médio, primeiramente o nariz, em 178 casos (36\%) e o mento em 365 casos (74\%). O plano oclusal apresentava-se inclinado, indicando uma assimetria vertical, em 201 casos (41\%). Os pacientes com Classe II, devido ou não à deficiência mandibular, apresentaram $28 \%$ de prevalência de assimetria, enquanto os de más oclusões de Classe III e Classe I apresentaram $40 \%$ de prevalência, tornando-se significantemente mais elevado do que aqueles com más oclusões de Classe II. Quando o mento se apresentava desviado transversalmente, houve $80 \%$ de chance que este desvio fosse para o lado esquerdo. Somente nos pacientes com face longa, houve um deslocamento igual do mento tanto para a esquerda como para a direita. Nos outros grupos, a prevalência do desvio do mento para o lado esquerdo alcançou $90 \%$. Concluíram que estes resultados são significantes para os clínicos porque a assimetria pode ser identificada e planejada antes do início do tratamento. 
Em 1998, SHEATS et al. ${ }^{164}$ estimaram a magnitude de prevalência da assimetria dentária e facial em jovens americanos, sem história de tratamento ortodôntico prévio e compararam com os dados estatísticos de um grupo submetido ao tratamento ortodôntico. A amostra de pacientes sem tratamento foi selecionada numa escola pública da Flórida, sendo composta de dois grupos de jovens: o primeiro era constituído de 5.817 jovens, com média de idade entre 9,3 \pm 0,8 anos e o segundo, de 861 adolescentes entre 14,4 \pm 0,5 anos. A assimetria de posição sagital do molar foi encontrada em $30 \%$ dos jovens do primeiro grupo e em $23 \%$ dos jovens do segundo grupo. Uma avaliação adicional da assimetria no segundo grupo mostrou $12 \%$ de assimetria facial e $21 \%$ de não coincidência das linhas médias dentárias. No grupo de pacientes em tratamento, verificaram que a assimetria mais comum era o desvio da linha média inferior em relação à linha média facial, ocorrendo em 62\% dos pacientes. Outras assimetrias ocorreram em ordem decrescente: falta de coincidência das linhas médias dentárias (46\%); desvio da linha média maxilar em relação à linha média facial (39\%); má oclusão assimétrica (22\%); assimetria oclusal maxilar (20\%); assimetria oclusal mandibular (18\%); assimetria facial (6\%); desvio do mento (4\%) e desvio nasal (3\%). Concluíram que não há associações significantes entre a assimetria facial e a não coincidência das linhas médias. Entretanto, associações estatisticamente significantes foram encontradas em relação à assimetria do molar e a assimetria facial, a assimetria do molar e a não coincidência das linhas médias e a assimetria do molar e o tipo racial. Os resultados desta pesquisa não puderam ser considerados precisos devido à deficiente metodologia para a avaliação da assimetria. Os autores comentaram que os examinadores não foram adequadamente calibrados e ainda, os pacientes avaliados não foram analisados quanto à presença de desvios da relação cêntrica para a oclusão cêntrica e nem mesmo, com relação à coincidência das linhas médias.

Ainda em 1998, SHROFF; SIEGEL ${ }^{167}$ comentaram que a fratura condilar na infância associa-se a um crescimento limitado, contruibuindo, conseqüentemente, para o aparecimento da assimetria. À medida que o crescimento facial prossegue, a 
mandíbula progressivamente desvia-se para o lado afetado, ou, em alguns casos, pode ocorrer um crescimento compensatório excessivo no lado da fratura, hiperplasia condilar, produzindo uma assimetria com desvio mandibular para o lado oposto ao afetado. Quando a articulação temporomandibular sofre uma injúria, ocorre a formação de uma artrose intracapsular, apresentando grande potencial para produzir uma anquilose articular ${ }^{124}$. Além da presença da assimetria, uma restrição na abertura bucal se manifesta devido à falta do movimento de translação condilar no lado afetado. Uma assimetria maxilar compensatória, uma inclinação do plano oclusal e uma disfunção temporomandibular podem estar associadas a estas assimetrias. As doenças degenerativas articulares unilaterais predispõem ao aparecimento da assimetria. A reabsorção condilar progressiva, quando ocorre bilateralmente, associa-se a uma mordida aberta anterior e a uma retrognatia mandibular progressiva. Nos casos de reabsorção condilar unilateral, a assimetria agrava-se paulatinamente e o lado afetado vai se tornando cada vez mais Classe II.

A maioria dos casos de mordida cruzada posterior ocorre quando a discrepância oclusal resulta da insuficiência da largura do arco superior em relação ao inferior. Em jovens, a mordida cruzada posterior unilateral usualmente acompanha o desvio funcional lateral mandibular do contato inicial até a máxima intercuspidação, resultando em uma intercuspidação deficiente e interferências oclusais. Este desvio funcional ocorre transversalmente, com a linha média dentária inferior desviada em direção ao lado cruzado em relação à linha média superior, bem como no sentido ântero-posterior, resultando geralmente numa má oclusão de Classe II, subdivisão no lado da mordida cruzada. LAM; SADOWSKY; OMERZA ${ }^{80}$, em 1999, verificaram a diferença entre a posição condilar em jovens com mordida cruzada funcional e jovens com má oclusão de Classe I, sem mordida cruzada. Além disso, avaliaram se havia uma alteração na posição condilar, após a correção da mordida cruzada pela expansão palatina. Trinta e um jovens entre seis a 14 anos, com mordida cruzada posterior unilateral foram comparados com uma amostra controle de 31 jovens entre 9 a 14 anos, exibindo Classe I de Angle, sem mordida cruzada. Radiografias submentonianas foram obtidas, antes do tratamento, para se estudar a assimetria esquelética, dentária e posicional com referência aos sistemas 
de coordenadas mandibulares e do assoalho craniano. Adicionalmente, os espaços condilares anterior, superior e posterior foram medidos para se determinar as diferenças entre os grupos com o uso de tomografias horizontais corrigidas da ATM, pré e pós-tratamento, além dos modelos de gesso. Finalmente, a distância entre a cúspide mesiovestibular do primeiro molar permanente superior à fossa vestibular do primeiro molar inferior foram medidas em ambos os grupos, antes do tratamento. Pela análise estatística, verificou-se que a mandíbula do grupo com mordida cruzada posterior funcional unilateral exibia uma assimetria nas dimensões ântero-posterior e transversa quando comparadas com o grupo de Classe I, sem mordida cruzada. Estas assimetrias provavelmente resultaram de um desvio funcional mandibular presente em todos os pacientes do grupo com mordida cruzada. Este desvio foi manifestado pela Classe II, subdivisão no lado da mordida cruzada como indicado na análise dos modelos. Os resultados das tomografias horizontais corrigidas não evidenciaram qualquer diferença na relação côndilo-fossa intra e intergrupos, pré e pós-tratamento.

$\mathrm{CRUZ}^{28}$, em 2000, avaliou as alterações dentoesqueléticas decorrentes do tratamento ortodôntico com extrações assimétricas de pacientes com má oclusão de Classe II, subdivisão de Angle, em relação a um grupo controle de oclusão normal. A amostra consistiu de três grupos, com 30 pacientes cada, apresentando as seguintes características: grupo 1 - jovens com Classe II, subdivisão, não tratados; grupo 2 - jovens com Classe II, subdivisão, tratados com extrações assimétricas; grupo 3 - jovens com oclusão normal. Todos apresentavam os dentes permanentes superiores e inferiores, em ambos os arcos dentários, até os primeiros molares, no início do tratamento. A média de idade da amostra foi de 15,76, 18,57 e 22,42 anos nos grupos de Classe II, subdivisão não tratado, Classe II, subdivisão tratado e oclusão normal, respectivamente. Medidas de diferenças relativas da posição espacial de pontos dentários e esqueléticos bilaterais foram obtidas nas radiografias submentoniana e póstero-anterior. $\mathrm{O}$ teste $\mathrm{t}$ para amostras independentes foi utilizado para comparar os grupos 1 e 2 com o grupo 3, em tempos diferentes. Considerou-se que o grupo 2 apresentava uma melhora concreta se as variáveis do grupo 1, que manifestaram uma diferença estatisticamente significante em relação 
ao grupo 3, não fossem estatisticamente diferentes do grupo com oclusão normal. Os resultados nas radiografias submentonianas demonstraram que as extrações assimétricas nas más oclusões de Classe II, subdivisão acentuaram as diferenças nas posições ântero-posteriores direita e esquerda, dos primeiros molares superiores e inferiores, como esperado com estes protocolos de extrações. Não houve alterações esqueléticas significantes que pudessem ser atribuídas às formas de tratamento investigadas e nem efeitos colaterais transversais com as mecânicas assimétricas empregadas. Também foi demonstrado que o tratamento da Classe II subdivisão com extrações assimétricas normaliza o posicionamento das linhas médias superior e inferior sem causar inclinação do plano oclusal ou de qualquer outro plano horizontal pesquisado, na análise da radiografia póstero-anterior. Portanto, concluiu-se que o tratamento da Classe II, subdivisão com extrações assimétricas constitui uma modalidade terapêutica válida para a solução deste problema.

Em 2003, LIMA ${ }^{86}$ determinou a distribuição dos tipos principais de Classe II, subdivisão, por meio da avaliação frontal. Posteriormente, estes subgrupos foram comparados com um grupo de oclusão normal para investigar a ocorrência de assimetria dentoesquelética, utilizando-se radiografias submentonianas e pósteroanteriores. O grupo experimental consistiu de 44 indivíduos que apresentavam má oclusão de Classe II, subdivisão, com média de idade de 15,3 anos. O grupo controle consistiu de 30 indivíduos que apresentavam oclusão normal, com média de idade de 22,42 anos. Todos apresentavam os dentes permanentes superiores e inferiores, em ambos os arcos dentários, até os primeiros molares e que não haviam sido submetidos a tratamento ortodôntico. A Classe II, subdivisão do tipo 1 apresenta uma coincidência da linha média dentária superior com a linha média facial e desvio da linha média dentária inferior. O tipo 2 apresentou características opostas. Duas examinadoras ${ }^{11,86}$ realizaram uma avaliação subjetiva das fotografias frontais. Para a avaliação da simetria, medidas de diferenças relativas da posição espacial de pontos dentários e esqueléticos bilaterais foram obtidas nas radiografias submentonianas e póstero-anteriores. Utilizou-se o teste $\mathrm{t}$ independente para a comparação das assimetrias dentoesqueléticas entre os subgrupos de Classe II, 
subdivisão, tipos 1 e 2 com o grupo de oclusão normal. Os resultados demonstraram que $61,36 \%$ dos casos de Classe II, subdivisão, foram do tipo 1 ; $18,18 \%$ foram do tipo 2 e 20,45\% foram considerados duvidosos. Os dois subgrupos de Classe II, subdivisão apresentavam um grau de assimetria esquelética semelhante ao grupo de oclusão normal. Portanto, concluiu-se que os principais componentes que contribuem para a relação ântero-posterior assimétrica na Classe II, subdivisão, tipos 1 e 2 são dentoalveolares.

Neste mesmo ano, AZEVEDO ${ }^{11}$ objetivou, primeiramente, avaliar a correlação entre a assimetria clínica e a assimetria radiográfica nos pacientes com Classe II, subdivisão. Secundariamente, o grau de assimetria esquelética entre os pacientes com este tipo de má oclusão e que apresentavam assimetria facial aparente foram comparados com o grau de assimetria dos indivíduos com oclusão normal. A amostra consistiu de 42 indivíduos com má oclusão de Classe II, subdivisão completa e 30 indivíduos com oclusão normal. A média de idade dos indivíduos foi de 15,21 e 22,42 anos no grupo com Classe II, subdivisão, e no grupo com oclusão normal, respectivamente. A assimetria clínica foi avaliada medindo-se a diferença relativa da posição espacial dos pontos do tecido mole entre os lados direito e esquerdo em fotografias frontais. A assimetria radiográfica foi avaliada medindo-se a diferença relativa da posição espacial dos pontos dentários e esqueléticos entre os lados direito e esquerdo nas dimensões ântero-posterior e transversal nas radiografias submentonianas e póstero-anteriores. Posteriormente, o teste de correlação de Pearson foi realizado entre as assimetrias nas fotografias e as assimetrias nas radiografias. O teste $t$ independente foi utilizado para comparar as assimetrias radiográficas de 23 indivíduos com Classe II, subdivisão com assimetria facial aparente com indivíduos com oclusão normal. A correlação entre a assimetria clínica e a assimetria radiográfica foi muito suave. Apesar das assimetrias encontradas serem predominantemente dentoalveolares, as más oclusões de Classe II, subdivisão, com assimetria facial aparente demonstram uma ligeira assimetria mandibular radiográfica em relação aos casos de Classe II, subdivisão, de uma forma geral. 
JANSON et al. ${ }^{69}$ (2003) investigaram e compararam os resultados decorrentes do tratamento de pacientes com má oclusão de Classe II, subdivisão de Angle, tratados sob dois protocolos distintos, o primeiro com extrações simétricas de quatro pré-molares e o segundo com extrações assimétricas de três pré-molares, sendo dois superiores e um inferior do lado da relação molar normal. Desta maneira, formaram-se dois grupos: o grupo 1 (G1) composto por modelos iniciais e finais de 28 jovens tratados com quatro extrações simétricas e o grupo 2 (G2) composto por modelos iniciais e finais de 23 jovens tratados com três extrações assimétricas. Realizou-se a comparação dos resultados obtidos, observando-se os modelos iniciais e finais de casos tratados pelos alunos de pós-graduação da disciplina de Ortodontia da Faculdade de Odontologia de Bauru - USP, com a técnica de edgewise simplificada, seguindo-se os dois protocolos de tratamento preconizados. Para a comparação, utilizou-se o Índice de Prioridades de Tratamento (IPT), proposto por GRAINGER ${ }^{50}$, estabelecendo-se índices ao início e ao final de cada tratamento proposto. Avaliou-se também, a correção dos desvios das linhas médias dentárias entre si, da sobremordida e da sobressaliência em cada um dos grupos. Os resultados indicaram que não houve diferença estatisticamente significante entre os dois grupos em relação ao IPT, apesar do Grupo 2 ter apresentado uma tendência de um menor IPT final. O tratamento com extrações assimétricas possibilitou uma melhor correção dos desvios das linhas médias dentárias superior e inferior entre si, comparado ao tratamento com extrações simétricas, demonstrando com isso uma ligeira superioridade do protocolo com extrações assimétricas nesses casos. Também não houve diferença significante para a sobremordida ou sobressaliência entre os dois grupos avaliados.

\subsection{Técnicas radiográficas para a avaliação da posição do terceiro molar}

A quantidade reduzida de espaço entre o segundo molar e o ramo tem sido identificada como o maior fator na etiologia da impacção do terceiro molar. O espaço localizado posteriormente ao segundo molar geralmente encontra-se reduzido em $90 \%$ dos casos de impacções ${ }^{20}$. Muitas técnicas têm sido descritas para se avaliar este espaço. 
DIERKES ${ }^{33}$, em 1975, utilizou radiografiais periapicais na região do terceiro molar para avaliar casos tratados ortodonticamente com extrações e verificou que o terceiro molar poderia estar impactado apesar do espaço suficiente aparente. RICHARDSON ${ }^{136}$, em 1977 , padronizou o cefalograma lateral a $60^{\circ}$ para medir a largura mesiodistal e estudar a área disponível do terceiro molar. TAITI; WILLIAMS ${ }^{176}$, em 1978, afirmaram que a radiografia lateral oblíqua seria a mais confiável para a mensuração do ângulo de irrupção do terceiro molar em relação ao plano mandibular. Em 1979, MACGREGOR ${ }^{90}$ assegurou que a ortopantomográfica seria eficiente para a avaliação do terceiro molar inferior quando da indicação de extração. OLIVE; BASFORD ${ }^{110}$ (1981) comentaram que as tomografias rotacionais eram consideradas as mais confiáveis, podendo-se também utilizar as panorâmicas, as radiografias interproximais e os cefalogramas laterais convencionais. A seguir, serão apresentados alguns trabalhos compulsados na literatura que empregaram as radiografias submentonianas, oblíquas e panorâmicas em suas metodologias.

\subsubsection{Considerações sobre as radiografias submentonianas}

A radiografia submentoniana apresenta grande potencial para a avaliação das assimetrias quando comparada à póstero-anterior por permitir que pontos anatômicos na base do crânio, que se encontram distantes dos ossos da face, sejam utilizados para a determinação do eixo sagital mediano ${ }^{39}$.

Em 1905, SCHUELLER ${ }^{157}$ descreveu pela primeira vez a radiografia submentoniana e mais tarde, MERRILL ${ }^{99}$, em 1949, reapresentou-a.

Investigando sobre a precisão da radiografia submentoniana, GILBERT ${ }^{43}$, em 1960, utilizou um filme radiográfico paralelo ao plano horizontal de Frankfurt e perpendicular ao solo. Utilizou um aparelho de Rx que produzia 140Kvp, para a obtenção de uma imagem nítida, sendo que o feixe de raios $X$ incidia no vértice do crânio. Este método foi considerado bastante útil na avaliação das assimetrias esqueléticas e nas deformações associadas às fissuras labiopalatais, apesar de nenhuma análise cefalométrica ter sido proposta. Apresentou também grande 
precisão para as mensurações de largura, entretanto, erros significantes foram encontrados nas medidas de comprimento das estruturas ${ }^{39}$.

Quem primeiro sugeriu a utilização da radiografia submentoniana na cefalometria foi BERGER ${ }^{15}$, em 1961, objetivando avaliar a assimetria. Para a obtenção desta projeção, determinou que a cabeça do paciente deveria estar posicionada num cefalostato, com o plano de Frankfurt perpendicular ao solo. A distância entre o tubo e o filme deveria ser de 1,50m. Para a orientação da avaliação das estruturas anatômicas, demarcou e traçou diversos pontos, linhas e planos. O ponto buccale foi localizado na região anterior da superfície interna do arco zigomático e o ponto angulare, na ponta de uma densa área radiopaca de forma triangular, formada pela união das bordas superior e inferior da órbita com o arco zigomático. Comentou que a conexão dos pontos buccale determina o plano buccale que passa pelos primeiros molares superiores, enquanto que a conexão do pontos angulare determina o plano angulare que corta o arco dentário entre os caninos e pré-molares. O plano condilar passa pelos contornos mais distais de cada côndilo. Para a determinação de uma linha média sagital, BERGER ${ }^{15}$ utilizou como orientação os seguintes pontos: crista galli, crista frontalis, vômer, tubérculo do atlas, processo odontóide e crista occipital interna. Como a simetria absoluta do crânio consiste numa situação muito rara, não foi possível traçar uma linha reta unindo todos esses pontos, tornando-se necessária alguma interpolação. Para completar o sistema de coordenadas, foi utilizada uma linha, perpendicular à linha sagital mediana, cortando-a ao meio. Estas linhas e os planos de orientação permitiam uma melhor visualização das assimetrias dentoesqueléticas das más oclusões. Entretanto, o autor não testou a reprodutibilidade e validade dessa linha de referência.

Em 1964, BERGER ${ }^{16}$ demonstrou um método para determinar a linha média da radiografia submentoniana, desenhando uma linha passando pelo vômer, pela parte posterior do septo nasal e pela crista galli. Afirmou que a radiografia submentoniana poderia ser utilizada simultaneamente com as projeções lateral e 
frontal para a análise das deformidades dentofaciais. Sugeriu que a linha média basilar uma vez construída poderia ser utilizada no estudo da assimetria facial.

O trabalho de MOSS; SALENTIJN ${ }^{105}$, em 1971, concluiu que a passagem e a localização dos feixes neuromusculares não podem ser violados durante 0 crescimento. Para tanto, basearam-se nos estudos da estabilidade e homogeneidade da localização do forame mentoniano que serviram de referência para o forame oval como pontos de construção para o eixo de referência sagital mediano. Advogaram que a radiografia submentoniana deve ser obtida com a cabeça posicionada de tal forma que o plano de Frankfurt esteja paralelo ao plano do filme e o plano sagital mediano pode ser derivado dos forames na base craniana. Em avaliações radiográficas de uma série relativamente grande de crânios em idades dentárias variadas, com implantes colocados nos forames oval, mandibular e mentoniano, revelaram que suas posições foram estáveis durante o crescimento.

Em 1979, MARMARY; ZILBERMAN; MIRSKY ${ }^{91}$ avaliaram a confiabilidade na construção de uma linha de referência média, usando os forames espinhosos como pontos de referência, pela vista basilar, para o estudo da assimetria. Radiografias submentonianas de 86 crânios secos foram realizadas, obtendo-se uma linha média em cada traçado, da seguinte forma: os centros dos forames espinhosos foram unidos e uma linha perpendicular foi traçada para servir como linha média, mensurando-se várias estruturas pareadas e não pareadas até essa linha média. Os desvios médios de cada ponto estavam dentro dos limites do erro de medição. A reprodutibilidade dessa técnica foi conferida por meio de um segundo traçado de oito radiografias selecionadas aleatoriamente. Concluíram que esta linha média vertical, construída perpendicularmente à linha horizontal formada pelos forames espinhosos, realmente assemelha-se ao plano sagital mediano, apresentando grande confiabilidade na avaliação do grau de assimetria presente em radiografias submentonianas. Afirmaram que estes forames permaneceriam constantes durante o período de crescimento e desenvolvimento craniofacial. 
Poucos trabalhos têm relatado o desenvolvimento da radiografia basilar como método de diagnóstico na avaliação e tratamento dos pacientes com anomalias craniofaciais. Em 1985, GRAYSON et al. ${ }^{52}$ aplicaram o método de traçado cefalométrico multiplanos ${ }^{53}$, utilizando a radiografia submentoniana e discutindo sua participação no diagnóstico e plano do tratamento ortodôntico. Nesta análise, o cefalograma foi traçado três vezes, definindo-se os pontos e as estruturas de três planos basilares e apresentando as instruções para o seu traçado. Afirmaram que este método auxilia no reestabelecimento do relacionamento tridimensional que existe nos filmes radiográficos com duas dimensões. Descreveram também um método para orientar a construção da linha média ântero-posterior de estruturas da base craniana. Esta linha média construída foi transportada para cada plano, sendo crítica para relacionar a localização e extensão da deformidade craniana na análise tridimensional. Neste trabalho, a análise cefalométrica basilar foi aplicada para o estudo de um indivíduo normal e de três pacientes com anormalidades craniofaciais, tais como o hipertelorismo orbital, a sinostose craniofacial e a microssomia hemicraniofacial. Para cada caso, a análise cefalométrica foi aplicada e os resultados radiográficos discutidos. Concluíram que os traçados pré-cirúrgicos nas radiografias basilares podem ser manipulados para simular as alterações esqueléticas previstas na cirurgia, como nas telerradiografias.

ARNOLD; ANDERSON; LILYEMARK ${ }^{9}$, em 1994, utilizaram a radiografia submentoniana para avaliar 44 adultos, com a análise de assimetria desenvolvida por RITUCCI; BURSTONE ${ }^{144}$, em 1981, e publicada por FORSBERG; BURSTONE; HANLEY ${ }^{39}$, em 1984. Comentaram que esta análise de assimetria consiste na utilização de pontos anatômicos bilaterais, criando sistemas de coordenadas de referência que podem ser utilizados para avaliar outros pontos. Três componentes foram analisados: a base do crânio, o complexo zigomaticomaxilar e a mandíbula e cada componente apresentava estruturas que eram analisadas quanto à assimetria, em relação ao sistema de referência do forame espinhoso, assim como em relação ao sistema de referência na linha média, originário daquele componente. Os côndilos também foram analisados em relação ao eixo intercondilar (um eixo médio de referência derivado da própria mandíbula) para determinar sua posição simétrica 
em relação à mandíbula. Esse sistema de análise permite estabelecer se a mandíbula está assimetricamente posicionada em relação à base craniana, ou se a estrutura mandibular apresenta uma forma assimétrica. Portanto, a base craniana apresentou medidas de assimetria realizadas em relação ao sistema de coordenadas de referência mediosagital, derivado dos forames espinhosos bilaterais. O complexo zigomaticomaxilar utilizou a linha transpterigomaxilar e sua bissetriz perpendicular como linha de referência mediosagital para medir a assimetria na região facial média ${ }^{9,39}$. Finalmente, a mandíbula apresentava um sistema de referência de coordenadas baseado na linha transcondilar e sua bissetriz perpendicular, para medir a assimetria dentro da mandíbula ${ }^{9,39}$. Diversas estruturas pareadas e não pareadas foram então avaliadas por comparação com esse sistema de coordenadas. Mensuraram a distância até as linhas médias, para as estruturas bilaterais, enquanto as diferenças foram calculadas e, para as estruturas não pareadas, mediram a distância até o plano sagital médio.

PINTO et al. ${ }^{118}$, em 2001, estudaram a assimetria morfológica e posicional da mandíbula em 15 jovens com mordida cruzada posterior unilateral funcional. Utilizaram uma amostra com nove jovens do gênero feminino e seis do gênero masculino, com média de idade de 8,8 anos, avaliados no início do tratamento e aproximadamente seis meses após a fase de contenção. Todos os pacientes apresentavam mordida cruzada posterior unilateral completa, envolvendo três ou mais dentes posteriores, um deslocamento funcional da relação cêntrica para a máxima intercuspidação habitual, e sem sinais ou sintomas de desordem temporomandibular. Realizaram um aumento transversal da maxila por meio da expansão rápida maxilar, durante um mês e por mais seis meses, como contenção. Utilizaram-se cortes tomográficos para avaliar o espaço articular, e radiografias submentonianas para avaliar a assimetria morfológica e posicional. Os resultados demonstraram que a mandíbula apresentava-se significantemente maior no lado não cruzado do que no lado cruzado. A assimetria foi mais evidente no ramo mandibular e envolveu os processos coronóide e condilar. O espaço articular póstero-superior apresentou-se mais amplo no lado não cruzado do que no lado cruzado. Após o tratamento e a contenção, a mandíbula não demonstrou assimetria morfológica 
significante. Houve maior crescimento mandibular no lado cruzado, comparando-se com o lado oposto, além de um reposicionamento mandibular. Verificou-se uma rotação anterior do lado cruzado em direção ao lado não cruzado. Concluiu-se que a mordida cruzada posterior unilateral causa assimetrias morfológicas e posicionais da mandíbula em jovens e que estas assimetrias podem ser amplamente corrigidas com a expansão precoce.

\subsubsection{Considerações sobre as radiografias oblíquas}

As radiografias oblíquas foram introduzidas na literatura por CARTWRIGHT; HARVOLD $^{26}$ (1954), e posteriormente utilizadas por POSEN ${ }^{121}$ (1957), objetivando mensurar a altura do corpo da mandíbula. Sua técnica de obtenção consiste em rotacionar o cefalostato de maneira que o plano sagital mediano do paciente se encontre a $45^{\circ}$ do chassi, estando ambos localizados perpendicularmente à fonte central de raios $X^{12}$. A cabeça do paciente deve ser orientada de maneira que o plano de Frankfurt fique paralelo ao solo. Este método radiográfico permite a mensuração da diferença entre os comprimentos mandibulares bilaterais ${ }^{26}$, a determinação do tamanho absoluto, a distorção de tamanho, em ambos os lados, com propósito de comparação, podendo-se realizar superposições das imagens ${ }^{121} \mathrm{e}$ cálculo da altura dentoalveolar dos dentes de ambos os lados da mandíbula ${ }^{121,122}$. Além disso, avalia a assimetria da morfologia condilar e dos ramos direito e esquerdo, assim como, a pneumatização do processo mastóide, a forma da fossa glenóide, o ângulo goníaco (forma e posição de ambos os lados e forma da borda inferior da mandíbula) e a altura vertical do plano oclusal em relação ao desenvolvimento vertical dos processos alveolares. A medição do comprimento alveolar na radiografia oblíqua requer a identificação de dois pontos: a sínfise e o côndilo. O ponto sínfise consiste no ponto médio da borda inferior da mandíbula, na região da sínfise, considerado um ponto confiável uma vez que esta região da mandíbula parece ser estável ${ }^{192}$. A radiografia póstero-anterior pode facilitar a localização deste ponto, pelo exame do contorno da sínfise, relacionando-a à radiografia oblíqua. Ainda mais, a identificação das raízes dos incisivos e caninos, permite demarcar este ponto no meio das raízes dos incisivos centrais. Na porção 
externa mais distal e posterior da cabeça condilar está o ponto condílio e a determinação do comprimento mandibular consiste em se medir a maior distância do ponto sínfise ao condílio, com uma precisão de $0,5 \mathrm{~mm}$.

Um dos grandes problemas dos trabalhos cefalométricos é a ampliação e a distorção nas projeções radiográficas ${ }^{179}$. Utilizando radiografias oblíquas e laterais, HATTON; GRAINGER ${ }^{57}$, em 1958, avaliaram 15 jovens de três anos de idade. Realizaram os traçados das radiografias duas vezes, investigando um ponto de mensuração na telerradiografia e dois, na radiografia oblíqua direita, sendo uma medida vertical (altura do molar) e uma horizontal, medida mesiodistal mandibular, que conectava a distal do molar à mesial do canino. Testes estatísticos foram utilizados para avaliar as variações nos traçados e nas técnicas radiográficas e concluíram que os erros podem ser considerados desprezíveis em comparação às diferenças entre os pacientes.

Objetivando mensurar os fatores de distorção e ampliação das radiografias oblíquas, BARBER; PRUZANSKY; KINDELSPERGER ${ }^{12}$ (1961) avaliaram a confiabilidade das medidas obtidas na radiografia oblíqua a $45^{\circ}$ em 10 crânios. Utilizaram marcadores de prata em 11 locais de cada metade da mandíbula e em oito locais de cada metade da maxila, permitindo a identificação destas áreas para posterior mensuração nos traçados. Realizaram-se 14 medidas mandibulares e 12 maxilares nas radiografias oblíquas direita e esquerda e diretamente no crânio. As medidas nas radiografias, considerando o fator de magnificação, foram utilizadas para se calcular a predição das medidas realizadas diretamente no crânio. Concluíram que as medidas calculadas correlacionavam-se com as medidas reais em centésimos de milímetros na maioria delas e variaram não mais que $0,3 \mathrm{~mm}$ em qualquer medida. Mencionaram que esse pequeno grau de variação entre as medidas indicou boa confiabilidade das medições realizadas na projeção oblíqua.

Averiguando se existia alguma relação entre o grau de inclinação mesioangular dos terceiros molares impactados e a quantidade de espaço disponível para estes dentes no arco dentário, $\mathrm{TAIT}^{176}$, em 1978, analisou 50 
radiografias laterais oblíquas de jovens entre as idades de 10,6 e 11,7 anos. Comprovou que o eixo mesiodistal da cripta dos terceiros molares inferiores no estágio de desenvolvimento precoce se mostra aproximadamente paralelo à superfície óssea na qual a cripta se desenvolve. Comentou que os primeiros sinais das criptas dos terceiros molares visíveis nestas radiografias consistem em pequenas depressões com formato de sino na superfície póstero-superior aos segundos molares inferiores. Esta região consiste na intersecção do ramo ascendente com a linha horizontal onde o osso se curva. A angulação da cripta do terceiro molar em relação aos outros dentes depende principalmente da posição desta curva onde a cripta inicia sua formação. Quanto mais posterior a curva se situa, mais inclinada se desenvolve a cripta e vice-versa. Provavelmente, a orientação dos terceiros molares superiores se assemelha ao formato da porção posterior da maxila. Como resultado, encontrou uma correlação significante entre a inclinação dos terceiros molares inferiores não irrompidos e a deficiência de espaço no arco dentário. Concluiu que a radiografia oblíqua oferece uma indicação mais precisa da angulação dos terceiros molares inferiores do que as telerradiografias.

Anos mais tarde, WOODSIDE ${ }^{190}$, em 1990, comentou que a medida dos comprimentos mandibulares nos cefalogramas oblíquos seria imprecisa. Afirmou que ao avaliar pacientes cirúrgicos, apresentando assimetria mandibular por meio de radiografias oblíquas a $45^{\circ}$, podem-se verificar grandes diferenças nas mensurações dos comprimentos mandibulares direito e esquerdo. Entretanto, quando se utiliza a radiografia submentoniana para a avaliação da posição mandibular, verificou-se que para estes casos, a angulação correta da projeção oblíqua raramente é de $45^{\circ}$. Explicou que o mento encontra-se geralmente desviado para o lado em que o comprimento mandibular está mais curto, resultando em diferença significante entre a relação dos planos mandibulares direito e esquerdo e o plano do filme, podendo assim alongar e aumentar a imagem subseqüente. Afirmou que a posição do plano mandibular em relação ao plano do filme deve ser ajustada para a obtenção de uma medida mais precisa, utilizando-se de radiografias submentonianas. 
Objetivando eliminar as imprecisões das radiografias oblíquas a $45^{\circ}$, em casos com assimetrias acentuadas, METAXAS ${ }^{100}$, em 1993, desenvolveu e testou o método da radiografia oblíqua corrigida, visando aumentar a precisão da medição do tamanho da mandíbula em ambos os lados. Para tanto, salientou que é necessário realizar inicialmente a radiografia submentoniana para a determinação do ângulo entre o corpo mandibular e o eixo transporiônico, dos lados direito e esquerdo. Após a aferição destes ângulos, obtêm-se as radiografias oblíquas corrigidas, de cada lado individualmente, ao invés de se utilizar o ângulo médio de $45^{\circ}$. Verificou que este procedimento proporciona uma maior precisão da medição do comprimento mandibular. Desta forma, para assegurar a precisão do método radiográfico, avaliou o crânio seco com vários graus de assimetria criados na mandíbula, objetivando avaliar e comparar os comprimentos mandibulares medidos nas radiografias oblíquas corrigidas, com os valores reais medidos diretamente no crânio seco. Colocou parafusos no corpo e ramo do lado esquerdo da mandíbula de maneira a simular 15 assimetrias. Radiografias oblíquas corrigidas direita e esquerda foram obtidas para cada grau de assimetria mandibular, objetivando mensurar o comprimento mandibular em cada filme. Utilizou implantes no côndilo, no crânio seco e na sínfise, assim com em outros pontos, implantes que criam marcadores radiopacos nos filmes, para eliminar a variabilidade nas medidas do comprimento mandibular, devido à identificação dos pontos. Um estudo do erro do método foi incorporado à pesquisa por meio da repetição das medidas do comprimento mandibular por três vezes levando à conclusão de que todas as medidas estavam dentro do padrão de precisão razoável. Os valores calculados e reais dos comprimentos mandibulares esquerdo e direito, nas 15 assimetrias, também foram comparados. Verificou-se que, para todas as assimetrias, a diferença entre os valores calculados e reais era menor que $1 \mathrm{~mm}$. A análise entre os valores calculados e reais demonstrou uma alta correlação para essa pequena amostra.

Utilizando como método de avaliação da precisão da radiografia oblíqua corrigida o centro geométrico dos lados mandibulares, GIAMBATISTINI ${ }^{42}$, em 1997, encontrou uma precisão menor do que a verificada por METAXAS ${ }^{100}$. Isto decorreu devido à sua metodologia não ter utilizado a linha que passa pelos pontos médios 
condilares até o centro da sínfise mentoniana. Desta forma, resultados diferentes foram encontrados em sua pesquisa.

\subsubsection{Considerações sobre as radiografias panorâmicas}

Reintroduzindo a radiografia panorâmica no cenário odontológico em 1949, o finlandês PAATERO ${ }^{111}$ apresentou a primeira publicação científica da aplicação da pantomografia, processo que registra na película radiográfica uma imagem nítida de uma superfície curva. Este termo significava para o autor a contração das palavras panorâmica e tomografia. Dois anos mais tarde, desenvolveu o protótipo do primeiro aparelho, obtendo a primeira radiografia de um paciente. Esta técnica tem ocupado uma crescente importância na maioria das especialidades da Odontologia ${ }^{112}$ e todos os aparelhos panorâmicos tomográficos existentes no mercado, praticamente, derivam dos estudos de PAATERO ${ }^{111}$.

As principais vantagens desta técnica consistem na baixa dose de radiação ao se comparar com a técnica radiográfica periapical completa da boca, ampla imagem da região anatômica, conveniência, simplicidade de operação, facilidade e rapidez do procedimento ${ }^{5,45}$. Uma das muitas utilidades das ortopantomográficas consiste na avaliação da angulação mesiodistal dos dentes irrompidos, não irrompidos, impactados e ectopicamente posicionados. Além de servirem para avaliação clínica, são também utilizadas antes, durante e após o tratamento ortodôntico para avaliar o paralelismo radicular e angulação dentária mesiodistal ${ }^{95}$.

Entretanto, as desvantagens das radiografias panorâmicas incluem a pobreza no detalhamento final, comparando-se com os filmes intrabucais e, a magnificação e distorção geométricas variáveis que são inerentes à imagem produzida ${ }^{45}$. Vários pesquisadores $^{87,96,117,150,151,153,181}$ estudaram as imagens nestes filmes, avaliando-se a projeção da angulação, magnificações horizontal e vertical, distorção angular, posição da cabeça dos pacientes e seus efeitos na precisão dimensional das radiografias panorâmicas. A distorção nos filmes panorâmicos no ângulo entre os dentes inclinados consiste no resultado das distorções combinadas nas dimensões 
vertical e horizontal ${ }^{96}$. Considerando a imprecisão dimensional inerente às imagens panorâmicas, parece razoável acreditar que a avaliação das angulações mesiodistais dos dentes não poderia ser confiável, quando realizada pelas radiografias panorâmicas.

O interesse despertado em vários pesquisadores pelo aprimoramento da técnica de PAATERO ${ }^{111}$ resultou em novos estudos e publicações científicas. Em 1952, NELSEN; KUMPULA ${ }^{106}$ constataram a importância da posição do paciente durante a exposição para que se mantivesse constante a relação filme, objeto e fonte de radiação. Contudo, sabe-se que isto não é possível, uma vez que as estruturas dentárias de cada paciente variam em função da forma e do tamanho do arco dentário. O diagnóstico e controle da cárie em populações numerosas foram considerados pelos autores a maior vantagem desta técnica.

Ainda em relação ao posicionamento do paciente no aparelho, PAATERO ${ }^{113}$, no ano de 1954, verificou que a imagem obtida apresentava-se melhor quando o plano de Frankfurt encontrava-se paralelo ao plano do solo, porém clinicamente a utilização do plano de Camper também era aceitável. O pantomógrafo consistia de uma cadeira motorizada, um porta-filme giratório e uma fonte de raios $X$ estacionária. Para a obtenção de uma pantomografia de uma estrutura curva, dobrava-se a película no formato do arco dentário e, esta e o paciente giravam com a mesma velocidade de deslocamento angular, porém em direções opostas.

O ápice das pesquisas de PAATERO ${ }^{112}$ ocorreu em 1961, com o desenvolvimento do ortopantomógrafo, que melhorou sobremaneira a produção da imagem, pois os aparelhos anteriores com apenas um ou dois eixos de rotação forneciam uma imagem com qualidade bem inferior a este, com três eixos de rotação independentes. Este mecanismo propiciou uma radiografia de toda a região maxilomandibular projetada de maneira ortorradial (perpendicular).

GILBERT $^{44}$, em 1962, ocupou-se com a viabilidade de se utilizar, em Ortodontia, radiografias panorâmicas obtidas com um aparelho da marca Panorex. 
No seu trabalho, evidenciou que na região dos molares ocorriam as maiores distorções lineares, porém o posicionamento adequado do paciente poderia reduzir este inconveniente. Destacou como vantagem da técnica o fato de permitir uma visualização das relações entre as coroas e as raízes dentárias com as estruturas ósseas, existindo uma acuidade angular e linear capaz de torná-la um instrumento confiável nas pesquisas clínicas.

SÄMFORS; WELANDER ${ }^{152}$ (1972) afirmaram que a radiografia panorâmica se compõe de uma série de fragmentos de imagens que vão sendo sucessivamente projetadas em um filme em movimento. Afirmaram que um movimento do paciente durante a obtenção da radiografia pode afetar a interrelação entre os fragmentos da formação da imagem da radiografia panorâmica, causando uma distorção geral da composição da imagem. A direção, extensão e duração do movimento durante a exposição radiográfica resultariam em diferentes efeitos sobre a radiografia resultante. Exemplificaram que quanto maior a amplitude do movimento, maior a distorção, e ainda, movimentos abruptos resultam em distorções que poderiam simular fraturas nos maxilares, ao passo que movimentos mais demorados resultam em uma distorção contínua da imagem radiográfica.

Dois anos mais tarde, SÄMFORS; WELANDER ${ }^{151}$ afirmaram que o fenômeno da distorção em radiografias rotacionais panorâmicas é fundamentalmente baseado no fato de que na dimensão vertical a imagem é formada devido a fonte de raios $X$ funcionar como foco, enquanto que a dimensão horizontal é dependente de uma projeção que tem como foco principal o centro de rotação. O fato é que, quando posicionado no plano central da camada de corte do aparelho, o objeto não sofrerá distorções, mas sim será uniformemente ampliado.

Em 1975, LUND; MASON-HING ${ }^{87}$ demonstraram as implicações clínicas da variação dos aparelhos panorâmicos. Mostraram que, quando há movimento da cabeça do paciente durante a obtenção da radiografia ou mau posicionamento do mesmo, a formação da imagem do arco é afetada, pois algumas regiões podem sair do plano de corte do aparelho, comprometendo o diagnóstico. Complementaram 
ainda que a rotação do eixo do mento tende a mover os dentes posteriores para fora do plano de corte do aparelho.

Em vista da grande popularidade da radiografia panorâmica e de seu emprego pelos ortodontistas na avaliação do paralelismo radicular, PHILLIP; HURST $^{117}$, em 1978, pesquisaram as distorções existentes na imagem produzida por um aparelho Panorex em função das diferentes inclinações do plano oclusal. Projetou-se um dispositivo simulando um arco dentário, com vários fios ortodônticos no sentido vertical, representando os dentes, soldados perpendicularmente a um fio de maior calibre, simulando o plano oclusal. Realizaram as obtenções das radiografias com diferentes inclinações do dispositivo, medindo os ângulos entre os fios verticais e o horizontal, observando que o menor grau de distorção correspondia à imagem obtida quando o plano oclusal do objeto era inclinado seis graus acima do plano horizontal. Dessa forma, os autores concluíram que a quantidade de distorção variava de acordo com a inclinação do plano oclusal, e que alterações de até cinco graus não apresentavam significado clínico na determinação do relacionamento aproximado dos longos eixos dos dentes.

MAYORAL ${ }^{95}$, em 1982, utilizou radiografias panorâmicas como meio de diagnóstico para avaliar o paralelismo radicular e o grau de reabsorção dos dentes adjacentes aos espaços das extrações ao final do tratamento ortodôntico. A amostra constou de ortopantomografias obtidas no início, no final do tratamento e um ano após a remoção da contenção de 53 casos tratados ortodonticamente com a extração dos primeiros pré-molares e a partir destas, foram traçados os longos eixos dos caninos e segundos pré-molares. O autor considerou uma variação entre -5 e +50: bom paralelismo; de +6 a $+10^{\circ}$ : aceitável; acima de $+11^{\circ}$ : deficiente; e abaixo de $-6^{\circ}$ : sobretratamento. Desta forma, encontrou $70 \%$ dos casos com paralelismo bom ou aceitável, sem que os espaços voltassem a abrir e os outros $30 \%$ da amostra apresentaram problemas de reabertura de espaço ou uma aproximação demasiada das raízes. Sendo assim, o autor sugeriu outras investigações utilizando estas radiografias com o intuito de verificar o relacionamento final dos caninos e prémolares. 
Em 1983, MLYNARSKA-ZDUANIAR ${ }^{101}$ avaliou as inclinações axiais dos longos eixos dos dentes permanentes irrompidos ou não em um aparelho da marca Panelipse. A amostra constituiu-se de radiografias panorâmicas pertencentes a 21 crianças, entre sete e oito anos de idade, com oclusão normal. Para efetuar as medições dos dentes superiores e inferiores, utilizou como referência um plano oclusal tocando as pontas das cúspides mais proeminentes dos primeiros molares permanentes superiores e inferiores respectivamente para cada arco dentário. Determinou os ângulos formados entre os longos eixos dos dentes anteriores aos segundos molares permanentes para este estágio de desenvolvimento oclusal, estabelecendo médias e desvios padrão.

A radiografia panorâmica constitui-se num método de diagnóstico e monitoramento do progresso do tratamento ortodôntico bastante difundido na classe odontológica. Em sendo um tipo de radiografia laminográfica, sua imagem sofre uma variedade de degraus de distorção linear, limitando sua utilização como ferramenta de diagnóstico. SAMAWI; BURKE ${ }^{150}$ (1984) investigando a precisão da projeção nas radiografias panorâmicas, utilizaram um dispositivo em tela metálica para representar a curvatura dos dentes nos arcos e pontos de chumbo, representando os longos eixos dos dentes e estruturas esqueléticas. Parâmetros angulares foram utilizados para identificar e avaliar tanto a magnitude como a distribuição da distorção angular nas imagens radiográficas. A região dos prémolares e caninos em ambos os arcos expressaram uma grande quantidade de distorção angular e variabilidade. De modo contrário, a região dos terceiros molares, juntamente com as marcações projetadas num nível inferior da radiografia foram menos variáveis. Concluíram que a utilização de medidas angulares obtidas nas ortopantomográficas é especialmente aplicável para a investigação do desenvolvimento dentário nas regiões posteriores, particularmente, os terceiros molares inferiores.

TAVANO et al. ${ }^{178}$, em 1989, mantendo o interesse em pesquisas sobre as avaliações angulares em radiografias ortopantomográficas, estabeleceram as linhas de referência para os arcos superior e inferior, no intuito de realizar avaliações 
angulares nestas radiografias. A princípio foram escolhidas cinco linhas, para posteriormente selecionar aquela que apresentasse maior facilidade de visualização radiográfica, menor alteração com o crescimento ou tratamento ortodôntico e proximidade com as estruturas dentoalveolares. Utilizaram três aparelhos diferentes para obtenção das radiografias e sobre elas foram traçados os reparos anatômicos e as linhas estudadas. Os autores selecionaram para medições das estruturas superiores, uma linha passando pelos pontos mais inferiores das órbitas e outra linha interceptando os pontos mais centrais dos forames mentonianos para as mensurações das estruturas inferiores da radiografia.

Objetivando estabelecer um padrão para as inclinações dentárias axiais mesiodistais, utilizando radiografias panorâmicas, URSI ${ }^{181}$, em 1990, empreendeu um interessante estudo. A amostra constituiu-se de 42 jovens brasileiros leucodermas de origem mediterrânea, com idades entre 12 e 17 anos, apresentando oclusão normal. Comparou os valores obtidos em quatro diferentes ortopantomógrafos e verificou que se pode utilizar o ortopantomógrafo, de fabricação nacional, da marca Funk como referência para uso clínico, apesar dos valores encontrados para os diversos aparelhos apresentarem diferenças estatisticamente significantes. Concluiu ainda que foi possível determinar um padrão médio normal para as inclinações axiais mesiodistais de todos os dentes irrompidos e que este padrão visa estabelecer bases quantitativas para a avaliação das inclinações axiais dentárias durante e após o tratamento ortodôntico, auxiliando na obtenção de resultados estáveis e com boa função oclusal.

Todo método radiográfico apresenta um certo grau de distorção que sofre variações decorrentes dos procedimentos técnicos. De acordo com PELTOLA; KONUNEM; NYSTROM ${ }^{114}$, em 1995, a radiografia panorâmica pode ser utilizada para detectar assimetrias da mandíbula, como as diferenças na forma e posição condilar entre os lados direito e esquerdo, as diferenças entre a altura e largura do ramo entre os dois lados, o grau de chanfradura antegoniana bilateral, a quantidade de desenvolvimento do corpo mandibular de ambos os lados, o desvio do ponto médio mandibular, a presença ou ausência de processo coronóide e a abertura do 
ângulo goníaco. Entretanto, a distorção e magnificação imprevisíveis da imagem limitam a precisão da informação.

Com o objetivo de analisar e comparar os índices de distorção da imagem radiográfica produzida em sete diferentes aparelhos panorâmicos, ÁVILA ${ }^{10}$ (1996), utilizou um crânio macerado de adulto ao qual foram fixados fios de chumbo em oito regiões anatômicas selecionadas. Outras estruturas foram submetidas a medições diretamente no crânio, constituindo ao todo doze regiões estudadas. A partir da comparação entre as medidas reais obtidas no crânio e aquelas obtidas nas imagens radiográficas dos aparelhos panorâmicos, verificou-se que o aparelho Rotograph 230 EUR apresentou o menor índice geral de distorção (19,95\%), sendo seguido pelo aparelho Panex EC (20,4\%), Super Veraview (22,17\%), Funk (23,29\%), Panoura 10C (23,45\%), GE 3000 (24,1\%) e Orthopantomograph OP-2 (28,55\%). As imagens radiográficas obtidas nos aparelhos panorâmicos testados apresentaram índices de distorção bastante variáveis (0-63,5\%), quando diferentes regiões foram consideradas nas radiografias. A região lateral que compreende de $3^{\circ}$ molar até o ramo ascendente mandibular, apresentou os menores índices de distorção (0-30\%), sendo que a região paramedial, de canino a $3^{\circ}$ molar, resultou nos maiores índices de distorção $(13,5-63,5 \%)$.

VENTÄ; MUTOMAA; YLIPAAVALNIEMI ${ }^{183}$, em 1997, avaliaram 40 terceiros molares de quarenta estudantes inicialmente aos 20 anos de idade do Instituto de Odontologia de Helsinki na Finlândia. O estudo foi designado para se prever por meio de um dispositivo predictivo os mesmos pacientes seis anos depois a fim de se avaliar as chances de irrupção e impacção dos terceiros molares, sobrepondo o dispositivo sobre radiografias panorâmicas. Concluíram que com o uso deste dispositivo elimina-se a necessidade de se elaborar medidas em cefalogramas, sendo fácil e simplificado para a aplicação rotineira em panorâmicas, radiografias mais convencionalmente solicitadas na clínica diária. Além disso, depois de testado o dispositivo, verificaram um índice de $95 \%$ de confiabilidade. 
AMIR et al. ${ }^{7}$, em 1998, objetivaram avaliar a precisão dimensional das medidas lineares e angulares na mandíbula em radiografias panorâmicas e ainda avaliar sua confiabilidade dimensional. Diferentes medidas realizadas por marcadores metálicos foram utilizadas em 25 mandíbulas dissecadas que foram radiografadas em um ortopantomógrafo. Realizaram medições linerares e angulares diretamente na peça dissecada e, posteriormente, nas imagens e comparam os valores obtidos. O estudo mostrou que medidas lineares obtidas da mandíbula no lado da panorâmica foram bem próximas das dimensões reais da mandíbula dissecada. Salientaram ainda que, embora tenham observado distorções nas medições lineares, a utilização da radiografia panorâmica para essas mensurações nos sentidos vertical, horizontal e oblíquo apresenta-se válida se estas forem realizadas apenas no mesmo lado da mandíbula. As medidas obtidas além da linha média da mandíbula foram distorcidas, portanto, não devendo se realizar comparações entre os lados.

Em 1999, BRUKS et al. $^{24}$ encetaram uma pesquisa para avaliar a necessidade e a importância dos exames radiográficos para o diagnóstico e plano de tratamento ortodôntico. Para tanto, de 70 jovens (33 do gênero masculino e 37 do gênero feminino), com média de idade de 13,3 anos foram obtidas radiografias panorâmicas, telerradiografias e periapicais, além de modelos de estudo. Os resultados enfatizaram a importância de uma seleção criteriosa e individual de radiografias para documentação ortodôntica uma vez que o ortodontista deve requisitar apenas as radiografias que julgar indispensável para o diagnóstico e planejamento de cada caso individualmente, prevenindo exposições desnecessárias às radiações ionizantes. A radiografia panorâmica, segundo esta investigação, foi o exame radiográfico mais freqüentemente requisitado, enquanto a telerradiogradia apresentou importância secundária para o planejamento dos casos.

Desta forma, MCKEE et al. ${ }^{97}$, em 2002, propuseram-se a comparar as verdadeiras angulações dentárias mesiodistais dos dentes de um typodont por meio de quatro diferentes aparelhos ortopantomógrafos, utilizando uma posição padrão da 
cabeça. Para tanto, utilizaram como material para estudo um typodont ${ }^{\odot}$ com dentes de segundo molar a segundo molar, em ambos os arcos dentários. Para cada dente acoplaram duas esferas de aço cromado medindo $1,58 \mathrm{~mm}$ de diâmetro, uma oclusal colocada na face vestibulolingual no ponto médio da face mesiodistal da coroa, e outra apical, na superfície radicular, dependendo do dente. Nos dentes anteriores, a esfera foi colocada no terço apical radicular e, para os dentes posteriores, no centro da bifurcação ou trifurcação. Estas esferas serviram como marcadores de referência para a determinação das angulações das imagens e uma linha imaginária unindo o centro das esferas oclusal, incisal e apical representada pelo longo eixo de cada dente no typodont. Os resultados forneceram, ao clínico, guias práticos para auxiliar na determinação da localização e extensão das imagens panorâmicas no diagnóstico e avaliação da posição radicular.

Em 2003, AKCAM; ALTIOK; OZDILER ${ }^{2}$ objetivaram investigar a possibilidade de melhorias da versatilidade clínica da radiografia panorâmica, ferramenta indispensável para o diagnóstico ortodôntico. Telerradiografias e panorâmicas foram obtidas de 30 pacientes. Um teste de correlação foi realizado entre as medidas paramétricas e o nível de predictibilidade das medidas cefalométricas das radiografias panorâmicas foi determinado utilizando equação regressiva. As equações mostraram que os parâmetros Go-Gn/SN, SNA-SNP/Go-Me (plano palatino/ plano mandibular) e Co-Go/Go-Me podem ser predizíveis nas radiografias panorâmicas dentro dos níveis de significância estatística e seus níveis de predictibilidade foram 20,6\%, 15,6\% e 11,2\%, respectivamente. Correlações estatisticamente significantes e níveis de predictibilidade também foram determinados nos cefalogramas e correspondentes parâmetros panorâmicos nos quais o plano horizontal de Frankfurt foi utilizado. Concluíram que mesmo que as panorâmicas promovam informações nas dimensões verticais das estruturas craniofaciais, deve-se atentar ao se recorrer a parâmetros cefalométricos esqueléticos nas radiografias panorâmicas, pois estas radiografias apresentam baixa porcentagem de predictibilidade.

\footnotetext{
(c) Ormco Corporation, Glendora, California.
} 


\section{Conclusões da Revisão de Literatura:}

1. A quantidade reduzida de espaço retromolar entre o segundo molar inferior e o ramo tem sido identificada como o maior fator na etiologia da impacção do terceiro molar inferior. O espaço localizado posteriormente ao segundo molar inferior geralmente encontra-se reduzido em $90 \%$ dos casos de impacções ${ }^{20}$.

2. A maioria dos casos tratados com extração de quatro pré-molares tiveram os terceiros molares irrompidos; enquanto que casos tratados sem extração apresentaram menor probabilidade de irrupção $33,36,75,76,126,134$.

3. Não foi encontrada prevalência de impacção dos terceiros molares de um dos $\operatorname{lados}^{30,58,161}$. A impacção dos terceiros molares parece ser mais freqüente para os molares superiores do que os inferiores ${ }^{30,77}$.

4. Os exames radiográficos dos terceiros molares inferiores em desenvolvimento revelaram que existe uma variação considerável no grau de angulação destes dentes de um indivíduo para outro e mesmo entre os lados direito e esquerdo do mesmo paciente ${ }^{135,175}$.

5. Verificou-se uma assimetria do espaço retromolar entre os lados esquerdo e direito em relação à impacção e irrupção dos terceiros molares. Entretanto, não foram encontradas diferenças significantes na angulação bilateral destes dentes ${ }^{55}$.

6. As técnicas radiográficas que possibilitam uma melhor avaliação das assimetrias craniofaciais são a submentoniana, oblíqua corrigida e pósteroanterior $^{11,12,28,39,42,52,65,86,100}$.

7. Quanto à precisão na aferição da angulação dos terceiros molares inferiores, verificou-se que as radiografias oblíquas a $45^{\circ}$ sobrepujam as telerradiografias ${ }^{176}$. Enquanto que as radiografias oblíquas corrigidas apresentam alto índice de correlação nas suas mensurações para ambos os lados, sendo precisas para a avaliação das assimetrias entre os lados esquerdo e direito de um paciente, apresentando grande confiabilidade ${ }^{100}$.

8. As radiografias panorâmicas ${ }^{111,112,113}$ tornaram-se fundamentais e imprescindíveis como meio auxiliar de diagnóstico amplamente empregado em todas as áreas da Odontologia. Fazem parte da documentação ortodôntica inicial, auxiliando no planejamento do tratamento, sendo úteis para a averiguação da presença dos 
quatro terceiros molares nos arcos dentários ${ }^{24,90,110}$. Entretanto, dentre alguns inconvenientes da técnica tem-se a imprecisão dimensional inerente às imagens panorâmicas decorrentes das ampliações combinadas nos sentidos vertical e horizontal $^{10,96,194}$.

9. Os componentes mais freqüentes que contribuem para a relação ântero-posterior assimétrica na Classe II, subdivisão são os dentoalveolares ${ }^{65}$. Além disso, a principal diferença entre a má oclusão de Classe II, subdivisão e a oclusão normal consiste numa posição mais distal do primeiro molar inferior do lado da Classe ${ }{ }^{65,145}$, em uma base óssea com assimetria normal. Uma diferença secundária consistiu na posição mais mesial do primeiro molar superior, no lado da Classe $1 I^{65}$.

10. O ortodontista necessita de razões para se planejar um caso indicando as extrações dos terceiros molares impactados e assintomáticos ${ }^{79}$. Entretanto, caso forem indicadas as extrações, devem ser removidos quando apresentarem no mínimo $2 / 3$ de raiz formada ${ }^{149}$, de preferência no jovem adulto e nunca muito precocemente ou tardiamente ${ }^{37,81,116}$. Na presença de impacção aos 18 anos, sem indicações para remoção, não se propõe a exodontia profilática do terceiro molar em virtude de muitos irromperem completamente com o tempo ${ }^{79}$. Análises detalhadas em exames radiográficos auxiliam o cirurgião na predição de possíveis dificuldades, reduzindo o índice de complicações pós-operatórias ${ }^{160}$.

A literatura compulsada ainda não relatou se existe alguma relação entre a assimetria de posição dos terceiros molares com a má oclusão de Classe II, subdivisão. Desta forma, este trabalho objetivou investigar se os espaços destinados aos terceiros molares superiores e inferiores e suas angulações sofrem influência da discrepância sagital assimétrica, na Classe II, subdivisão. 


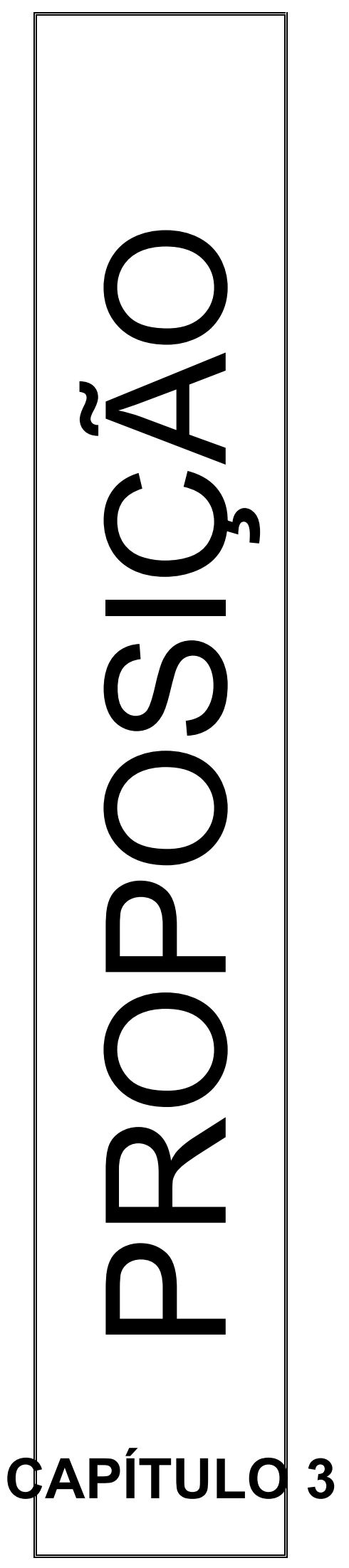




\section{PROPOSIÇÃO}

objetivo deste trabalho consistiu em:

Avaliar por meio das radiografias oblíquas corrigidas e ortopantomográficas, se o espaço destinado à irrupção dos terceiros molares superiores e inferiores, e sua angulação, sofrem influência das assimetrias ântero-posteriores dos dentes posteriores, na Classe II, subdivisão e nos seus subgrupos. Portanto a seguinte hipótese nula será testada: "Não há diferença entre o espaço disponível ou na angulação dos terceiros molares superiores e inferiores entre os lados de Classe I e de Classe II, na má oclusão de Classe II, subdivisão". Esta hipótese será rejeitada se estas variáveis forem diferentes entre os dois lados mencionados. 


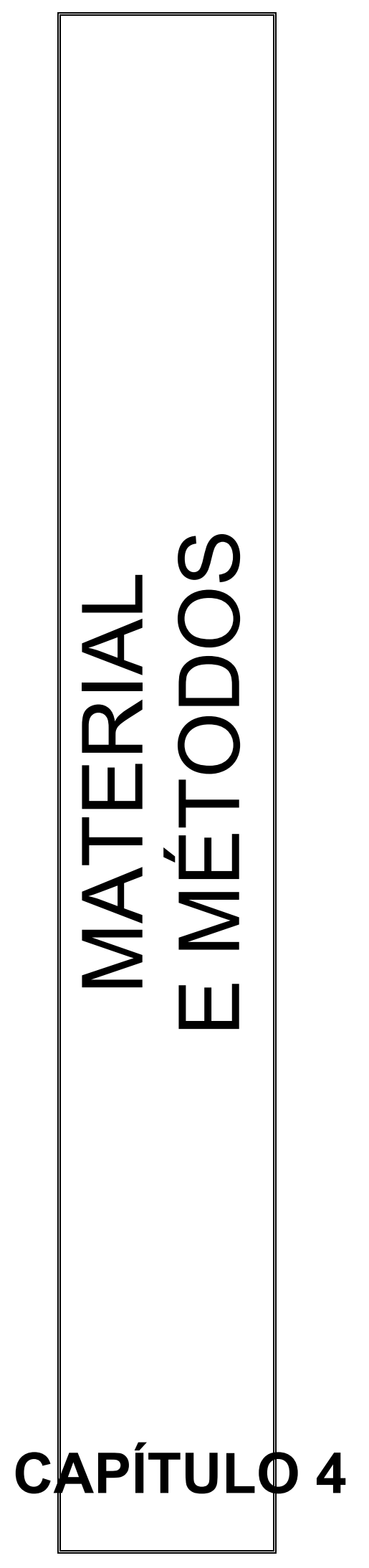




\section{4- MATERIAL E MÉTODOS}

\section{1- Material}

\section{A}

amostra consistiu de dois grupos: o grupo experimental (grupo 1) composto de 29 pacientes com má oclusão de Classe II, subdivisão, de Angle com relação molar de Classe II completa de um lado e de Classe I, do outro (Figuras 4.1a e 4.1b), sendo 17 do gênero masculino e 12 do feminino, com média de idade de 14,73 anos. Dois subgrupos foram classificados dentre o total de casos do grupo 1, de acordo com as duas etiologias da Classe II, subdivisão $3,28,65,145$ : subgrupo Tipo 1 (18 casos, sendo 10 do gênero masculino e 8 do feminino) caracterizado pela coincidência da linha média dentária superior em relação ao plano sagital mediano e desvio de linha média inferior em direção ao lado da Classe II. O subgrupo Tipo 2 (6 casos, sendo 4 do gênero masculino e 2 do feminino) apresentava coincidência da linha média dentária inferior em relação ao plano sagital mediano e desvio da linha média dentária superior em sentido contrário ao lado da Classe II. O grupo controle (grupo 2) constituído de 17 pacientes com oclusão normal (Figura 4.2) foi selecionado dentre estudantes e funcionários da Faculdade de Odontologia de Bauru-USP, sendo 11 do gênero feminino e 6 do masculino, com média de idade de 21,73 anos. O grupo de oclusão normal foi incluído neste trabalho para auxiliar na comparação estatística das assimetrias lineares e angulares dos terceiros molares em relação aos grupos experimentais.

De todos os pacientes da amostra, parte do grupo experimental (18 participantes) e todos os 17 pacientes do grupo controle já haviam sido previamente selecionados e documentados em pesquisa realizada anteriormente ${ }^{65}$. Os outros pacientes (11 indivíduos) do grupo de má oclusão foram triados dentre os 600 indivíduos que procuraram tratamento ortodôntico na Disciplina de Ortodontia da Faculdade de Odontologia de Bauru-USP, sendo todos documentados para o acervo do Departamento desta Instituição.

Dois critérios básicos foram adotados para a seleção da amostra: 1- Todos os pacientes deveriam apresentar os terceiros molares superiores e inferiores presentes em todos os quadrantes ${ }^{33,184} ; 2$ - Todos os dentes permanentes superiores 
e inferiores, em ambos os arcos dentários deveriam estar presentes $3,28,65,93,145,162$. Como critérios adicionais, convencionou-se que: 3- Não deveriam ter sido tratados ortodonticamente $28,65,93,145 ; 4$ - Não poderiam apresentar deslocamento mandibular lateral durante 0 fechamento bucal, detectado durante 0 exame clínico $^{3,28,65,93,145,156,162}$; 5- Não deveriam apresentar histórico de trauma facial, ou condições médicas que poderiam alterar 0 crescimento das bases apicais $^{28,65,76,93,124,145,170} ; 6$ - Tolerância de no máximo três milímetros de apinhamento simétrico nos arcos dentários superior e/ou inferior, desde que simétrico ${ }^{11,28,65,86}$. A presença desses critérios foi avaliada pela pesquisadora por meio de anamnese, exames clínico e radiográfico.

$\mathrm{Na}$ amostra dos 29 pacientes do grupo experimental, verificou-se que os tipos de Classe II, subdivisão se apresentavam de acordo com o principal fator etiológico da subdivisão. JANSON ${ }^{65,66}$ classificou as más oclusões de Classe II, subdivisão em dois tipos: Tipo 1 (nos casos em que a linha média dentária inferior estava desviada para o lado da relação molar de Classe II e a linha média dentária superior estava coincidente com o plano sagital mediano, estando o molar inferior posicionado mais para distal do lado da Classe II) e Tipo 2 (nos casos em que a linha média dentária superior estava desviada em sentido contrário ao lado da relação molar de Classe II e quando o molar superior estava posicionado mais para mesial, em relação de Classe II, estando a linha média dentária inferior coincidente em relação ao plano sagital mediano). Baseando-se nessa forma de avaliação, quantificou-se o número de casos que apresentavam os dois tipos principais de Classe II, subdivisão. Para tanto, foram avaliados por meio das fotografias frontais ${ }^{11,86}$ os desvios das linhas médias dentárias em relação a uma linha imaginária, perpendicular ao solo, passando pelo centro da glabela $^{72}$. Assim, subdividiu-se o grupo de Classe II, subdivisão em dois subrupos: a) subgrupo Tipo 1 (Classe II, subdivisão - Tipo 1) linha média dentária superior coincidente e inferior desviada - (18 casos) e b) subgrupo Tipo 2 (Classe II, subdivisão - Tipo 2) - linha média dentária inferior coincidente e superior desviada - (6 casos). Os demais indivíduos do grupo experimental (5 casos) que apresentavam uma combinação destas duas etiologias não foram incluídos na avaliação individual dos subgrupos. 

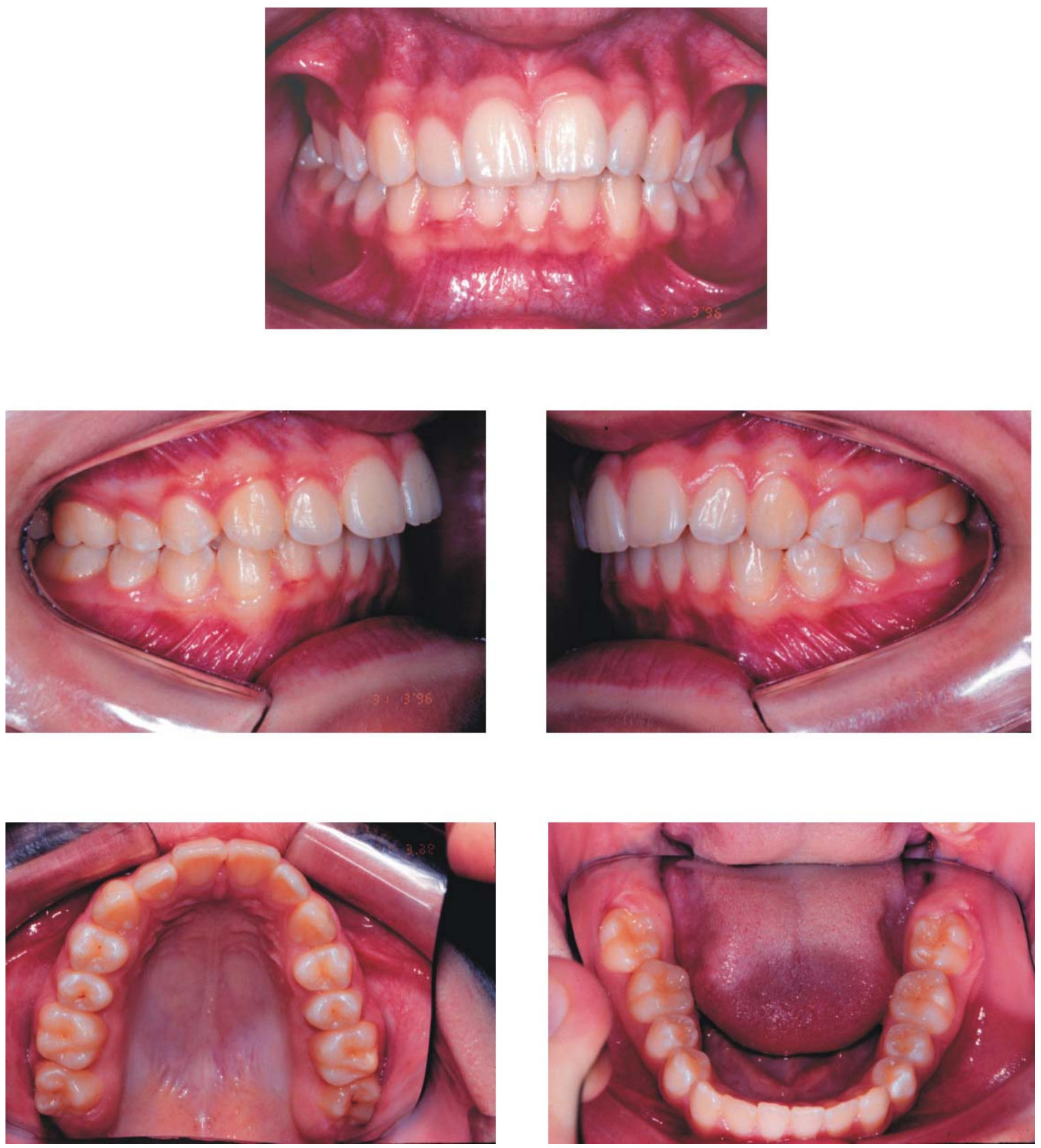

Figura 4.1a - Fotografias intrabucais de um paciente pertencente ao Grupo 1 (Classe II, subdivisão). 

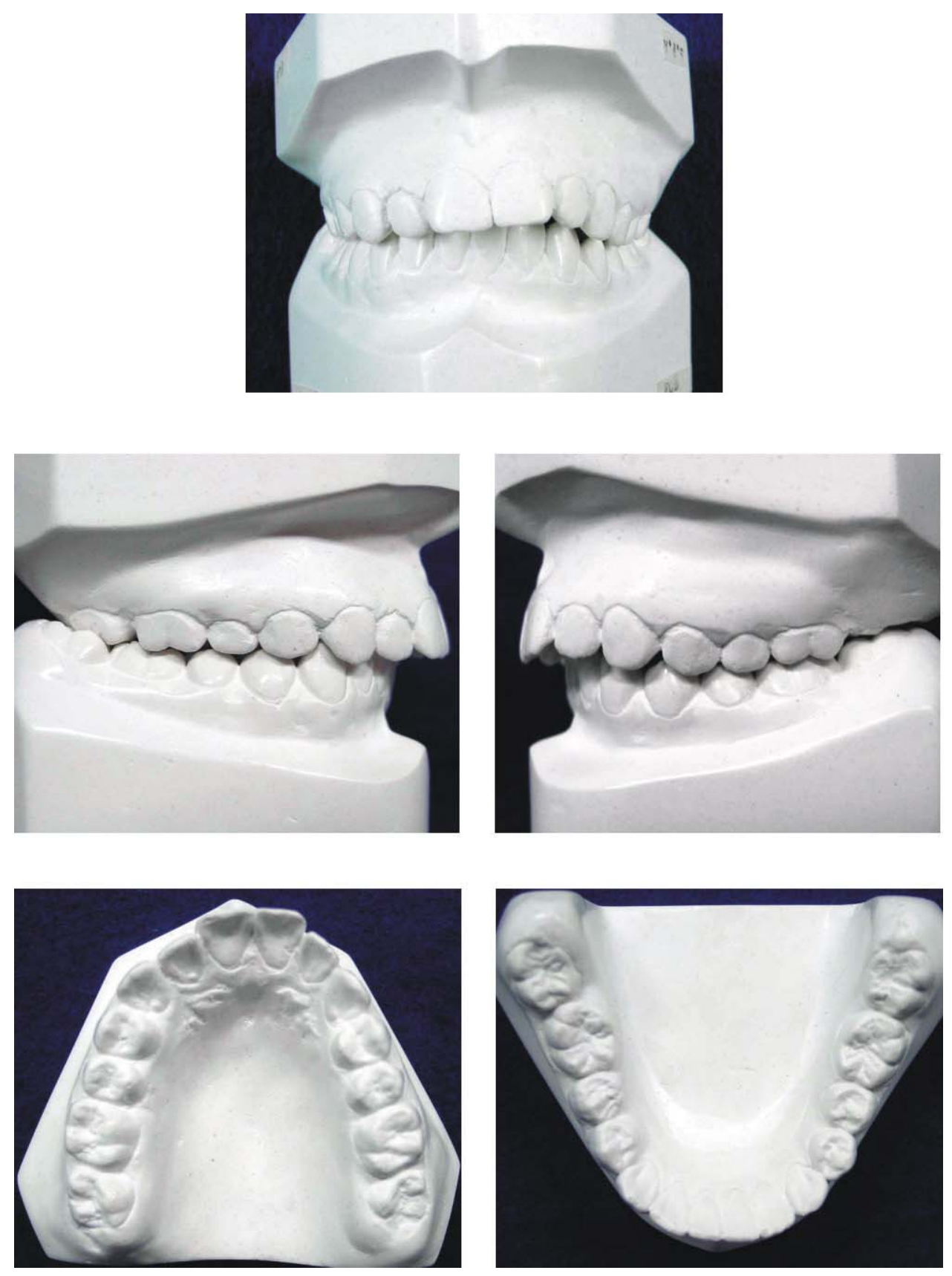

Figura 4.1b - Fotografias dos modelos do mesmo paciente ilustrado anteriormente pertencente ao Grupo 1 (Classe II, subdivisão). 

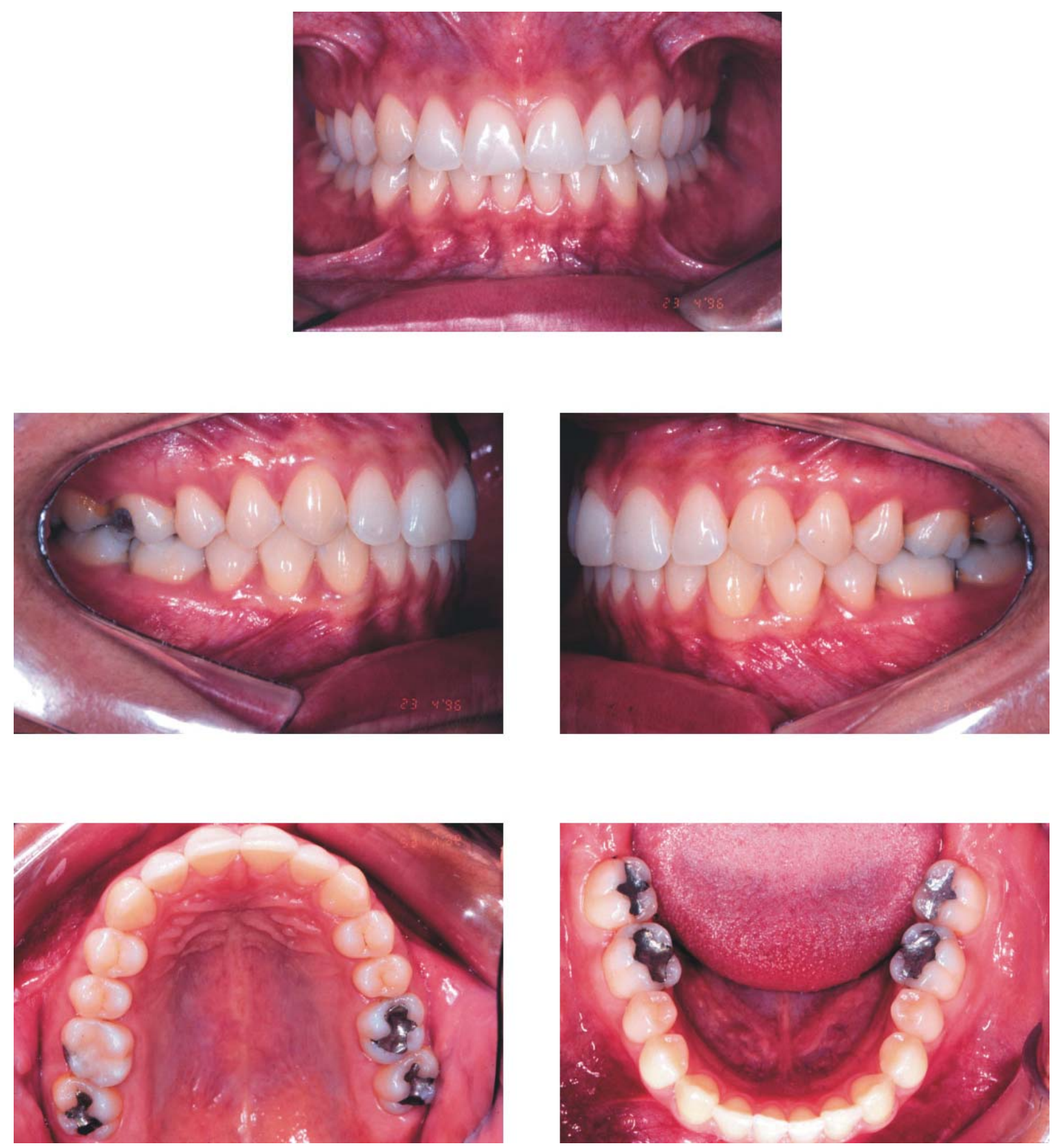

Figura 4.2 - Fotografias intrabucais de um paciente pertencente ao Grupo 2 (oclusão normal). 


\subsection{Métodos}

De cada indivíduo foram obtidas quatro radiografias: uma submentoniana, duas oblíquas corrigidas (lados direito e esquerdo) e uma ortopantomográfica. As radiografias obtidas foram processadas automaticamente, sendo os traçados anatômicos e a demarcação dos pontos realizados manualmente, em papel de acetato transparente "ultraphan" sobre um negatoscópio, em uma sala escurecida. Para melhor delimitação das estruturas anatômicas, adaptou-se uma máscara de cartolina preta ao redor da radiografia, de modo a eliminar ao máximo a luminosidade lateral proveniente do negatoscópio. Os traçados cefalométricos e os pontos foram realizados com uma lapiseira pentel provida com grafite $\mathrm{HB}$, de $0,3 \mathrm{~mm}$ de diâmetro. Os pontos foram digitalizados por meio de uma mesa digitalizadora Hipad $D T-11^{1}$, conectada a um microcomputador Pentium III - 800mhz, para a obtenção das grandezas cefalométricas. Para a realização das mensurações dos pontos digitalizados, utilizou-se o programa Dentofacial Planner 7.0².

\subsubsection{Radiografias submentonianas}

A técnica das radiografias submentonianas (Figura 4.3) baseou-se em metodologias já citadas na literatura ${ }^{11,28,39,52,65,80,85,86,107}$. Cada indivíduo foi posicionado sentado em um banco sem encosto de forma que sua cabeça fosse rotacionada para trás, até que o plano de Frankfurt se apresentasse paralelo ao chassi. Como esta posição era bastante desconfortável, causando um certo desequilíbrio, o paciente foi orientado a segurar com as duas mãos, em uma mesa de apoio fixa, posicionada à sua frente. O aparelho utilizado para a radiografia foi o TUR $D 800^{3}$, com filme Kodak X-Omat $K$ (não interfoliado) e com tempo de exposição de $0,125 \mathrm{~s}$, a $70 \mathrm{kv}$ e $32 \mathrm{~mA}$. A distância do ponto focal até as olivas metálicas foi padronizada em $152 \mathrm{~cm}$ e a distância das olivas metálicas até o filme, fixada em $16 \mathrm{~cm}$, o que forneceu um fator de magnificação de 9,55\%. Durante a obtenção da radiografia, os pacientes deveriam manter os dentes em máxima intercuspidação habitual, sob ligeira pressão.

\footnotetext{
${ }^{1}$ Houston Instruments, Houston, Texas.

${ }^{2}$ Dentofacial Planner Software Inc., 100 Simcoe Street, Suite 303, Toronto, Ontario, Canadá M5H3G2.

${ }^{3}$ Dresden, Alemanha (VEB Transformatoren - und Röntgenwerk < Hermann Matern $>$ ).
} 
Para o traçado das estruturas anatômicas de interesse, demarcação dos pontos e linhas e medição das grandezas cefalométricas, utilizou-se a análise de RITUCCI; BURSTONE ${ }^{39,144}$, com algumas modificações de interesse para esta pesquisa.

\subsubsection{1 - Estruturas anatômicas (Figura 4.4):}

1 Forame Magno.

2 Forames espinhosos.

3 Olivas metálicas.

4 Mandíbula (incluindo côndilos, ângulos goníacos e processos coronóides).

5 Abóbada craniana posterior.

6 Arcos zigomáticos.

7 Abóbada craniana anterior.

8 Fissuras pterigomaxilares.

9 Vômer.

10 Primeiros molares superiores.

11 Primeiros molares inferiores.

12 Incisivos centrais superiores.

13 Incisivos centrais inferiores.

\subsubsection{2 - Pontos de referência (Figura 4.5):}

1 O centro medial da oliva metálica direita.

2 O centro medial da oliva metálica esquerda.

3 Gônio direito (GOD) - Ponto médio mediolateralmente na borda posterior do ângulo goníaco direito.

4 Gônio esquerdo (GOE) - Ponto médio mediolateralmente na borda posterior do ângulo goníaco esquerdo.

5 Ponto condilar médio direito (PCMD) - Ponto médio de uma linha que conecta os pontos medial e lateral da cabeça condilar direita.

6 Ponto condilar médio esquerdo (PCME) - Ponto médio de uma linha que conecta os pontos medial e lateral da cabeça condilar esquerda. 
7 Ponto condilar medial direito (PCMD) - O ponto onde uma linha traçada paralelamente ao corpo mandibular toca a porção medial do côndilo direito.

8 Ponto condilar medial esquerdo (PCME) - O ponto onde uma linha traçada paralelamente ao corpo mandibular toca a porção medial do côndilo esquerdo.

9 Ponto condilar lateral direito (PCLD) - O ponto onde uma linha traçada paralelamente ao corpo mandibular toca a porção lateral do côndilo direito.

10 Ponto condilar lateral esquerdo (PCLE) - O ponto onde uma linha traçada paralelamente ao corpo mandibular toca a porção lateral do côndilo esquerdo.

11 Distal do primeiro molar inferior direito (DPMID) - O ponto mais distal alinhado com o sulco mesiodistal central do primeiro molar inferior direito.

12 Distal do primeiro molar inferior esquerdo (DPMIE) - O ponto mais distal alinhado com o sulco mesiodistal central do primeiro molar inferior esquerdo.

13 Processo coronóide direito (PCD) - O ponto mais anterior, em relação à linha condilar, no processo coronóide direito.

14 Processo coronóide esquerdo (PCE) - O ponto mais anterior, em relação à linha condilar, no processo coronóide esquerdo.

15 Linha média mandibular (LMM) - O ponto mais anterior do corpo da mandíbula, consistindo num ponto esquelético.

16 Linha média dentária inferior (LMDI) - O ponto de contato entre as superfícies mesiais das coroas dos incisivos centrais inferiores.

17 Forame espinhoso direito (FED) - O centro geométrico do forame espinhoso direito.

18 Forame espinhoso esquerdo (FEE) - O centro geométrico do forame espinhoso esquerdo.

19 Linha média dentária superior (LMDS) - O ponto de contato entre as superfícies mesiais das coroas dos incisivos centrais superiores.

20 Vômer anterior (VA) - Intersecção do vômer com uma linha que conecta os pontos angulares direito e esquerdo.

21 Vômer posterior (VP) - Intersecção do vômer com uma linha que conecta os pontos das fissuras pterigomaxilar (PTM) direita e esquerda. 
22 Angulare direito $(A D)^{15,16}$ - Ponto mais anterior, em relação à linha PTM, das opacidades triangulares presentes no ângulo orbital externo, onde as bordas superior e inferior da órbita se encontram e onde o arco zigomático se insere.

23 Angulare esquerdo $(\mathrm{AE})^{15,16}$ - Vide ponto 22.

24 Buccale direito (BD) ${ }^{15,16}$ - Ponto na superfície interna do arco zigomático direito, onde o mesmo se curva mesialmente e, em seguida, para trás.

25 Buccale esquerdo $(\mathrm{BE})^{15,16}$ - Ponto na superfície interna do arco zigomático esquerdo, onde o mesmo se curva para medial e, em seguida, para trás.

26 Fossa craniana média direita (FCMD) - Ponto mais anterior, em relação à linha interespinhosos, na asa menor do osso esfenóide.

27 Fossa craniana média esquerda (FCME) - Vide ponto 26.

28 Fissura pterigomaxilar direita (FPTMD) - Ponto mais medial e posterior da fissura pterigomaxilar direita. A linha PTM conecta os pontos PTMD e PTME.

29 Fissura pterigomaxilar esquerda (FPTME) - Ponto mais medial e posterior da fissura pterigomaxilar esquerda.

30 Zígio direito (ZD) - Ponto localizado na intersecção da borda lateral do arco zigomático direito, obtido pelo prolongamento da linha PTM e traçado pela secção de maior largura da distância bizigomática.

31 Zígio esquerdo (ZE) - Ponto localizado na intersecção da borda lateral do arco zigomático esquerdo, obtido pelo prolongamento da linha PTM e traçado pela secção de maior largura da distância bizigomática.

32 Abóbada craniana anterior direita (ACAD) - Ponto onde a borda lateral do crânio é interceptada por uma linha que conecta os pontos zígio direito e esquerdo.

33 Abóbada craniana anterior esquerda (ACAE) - Ponto onde a borda lateral do crânio é interceptada por uma linha que conecta os pontos zígio direito e esquerdo.

34 Básio $(\mathrm{Ba})$ - Ponto mais anterior, em relação à linha interespinhosos, na borda anterior do forame magno.

35 Opístio (Op) - Ponto mais posterior, em relação à linha interespinhosos, na borda posterior do forame magno. 
36 Abóbada craniana posterior direita (ACPD) - Ponto onde a borda lateral direita da abóbada craniana é interceptada por uma linha paralela à linha interespinhosos, traçada pela abóbada craniana, em sua secção de maior largura.

37 Abóbada craniana posterior esquerda (ACPE) - Ponto onde a borda lateral esquerda da abóbada craniana é interceptada por uma linha paralela à linha interespinhosos, traçada pela abóbada craniana, em sua secção de maior largura.

38 Contorno médio da mandíbula do lado direito (CMMD) - Ponto mais medial e posterior, no contorno médio do corpo da mandíbula, do lado direito.

39 Contorno médio da mandíbula do lado esquerdo (CMME) - Ponto mais medial e posterior, no contorno médio do corpo da mandíbula, do lado esquerdo.

40 Ponto médio do eixo transespinhosos (PMETE) - Ponto médio na linha que une o centro geométrico dos pontos dos forames espinhosos.

41 Ponto perpendicular ao eixo transespinhosos (PERPETE) - Ponto demarcado perpendicularmente ao eixo transforame espinhoso, à frente do mento, eqüidistante dos forames espinhosos (este $e$ os outros pontos perpendiculares aos eixos das abscissas foram utilizados apenas para possibilitar o traçado dos eixos das ordenadas).

42 Ponto perpendicular ao eixo transcondilar (PERPETC) - Ponto demarcado perpendicularmente ao eixo transcondilar, à frente do mento, eqüidistante dos pontos médios condilares.

43 Ponto médio do eixo transcondilar (PMETC) - Ponto médio entre os dois pontos condilares médios, no eixo transcondilar.

44 Ponto médio do eixo transpterigomaxilar (PMETPTM) - O ponto médio entre os dois pontos FPTM (fissura pterigomaxilar, direita e esquerda), no eixo transpterigomaxilar.

45 Ponto perpendicular ao eixo transpterigomaxilar (PERPETPTM) - Um ponto demarcado perpendicularmente ao eixo transpterigomaxilar, à frente do mento, eqüidistante dos pontos FPTM.

46 Ponto médio do eixo transmolar (PMETM) - Ponto médio entre os dois pontos DPMI (distal do primeiro molar inferior direito e esquerdo), no eixo transmolar. 
47 Ponto perpendicular ao eixo transmolar (PERPETM) - Um ponto demarcado perpendicularmente ao eixo transmolar, à frente do mento, eqüidistante dos pontos DPMID e DPMIE.

48 Centro da face vestibular do primeiro molar inferior direito (CVPMID).

49 Centro da face vestibular do primeiro molar inferior esquerdo (CVPMIE).

50 Borda mandibular direita (BMD) - Ponto onde a linha perpendicular à face vestibular do primeiro molar inferior direito intercepta a borda mandibular.

51 Borda mandibular esquerda (BME) - Ponto onde a linha perpendicular à face vestibular do primeiro molar inferior esquerdo intercepta a borda mandibular.

52 Ponto na distal do primeiro molar superior direito (PDMSD) - Ponto mais distal, alinhado com o sulco principal do primeiro molar superior direito.

53 Ponto na distal do primeiro molar superior esquerdo (PDMSE) - Ponto mais distal, alinhado com o sulco principal do primeiro molar superior esquerdo.

54 Centro da face vestibular do primeiro molar superior direito (CVPMSD).

55 Centro da face vestibular do primeiro molar superior esquerdo (CVPMSE).

56 Borda mandibular superior direita (BMSD) - Ponto onde a perpendicular à face vestibular do primeiro molar superior direito intercepta a borda mandibular.

57 Borda mandibular superior esquerda (BMSE) - Ponto onde a perpendicular à face vestibular do primeiro molar superior esquerdo intercepta a borda mandibular.

58 Ponto médio do eixo transmolar superior (PMETMS) - Ponto médio entre os dois pontos nas distais dos primeiros molares superiores direito e esquerdo no eixo transmolar superior.

59 Ponto perpendicular ao eixo transmolar superior (PERPETMS) - Ponto demarcado perpendicularmente ao eixo transmolar superior, à frente do mento, eqüidistante dos pontos DPMSD e DPMSE. 


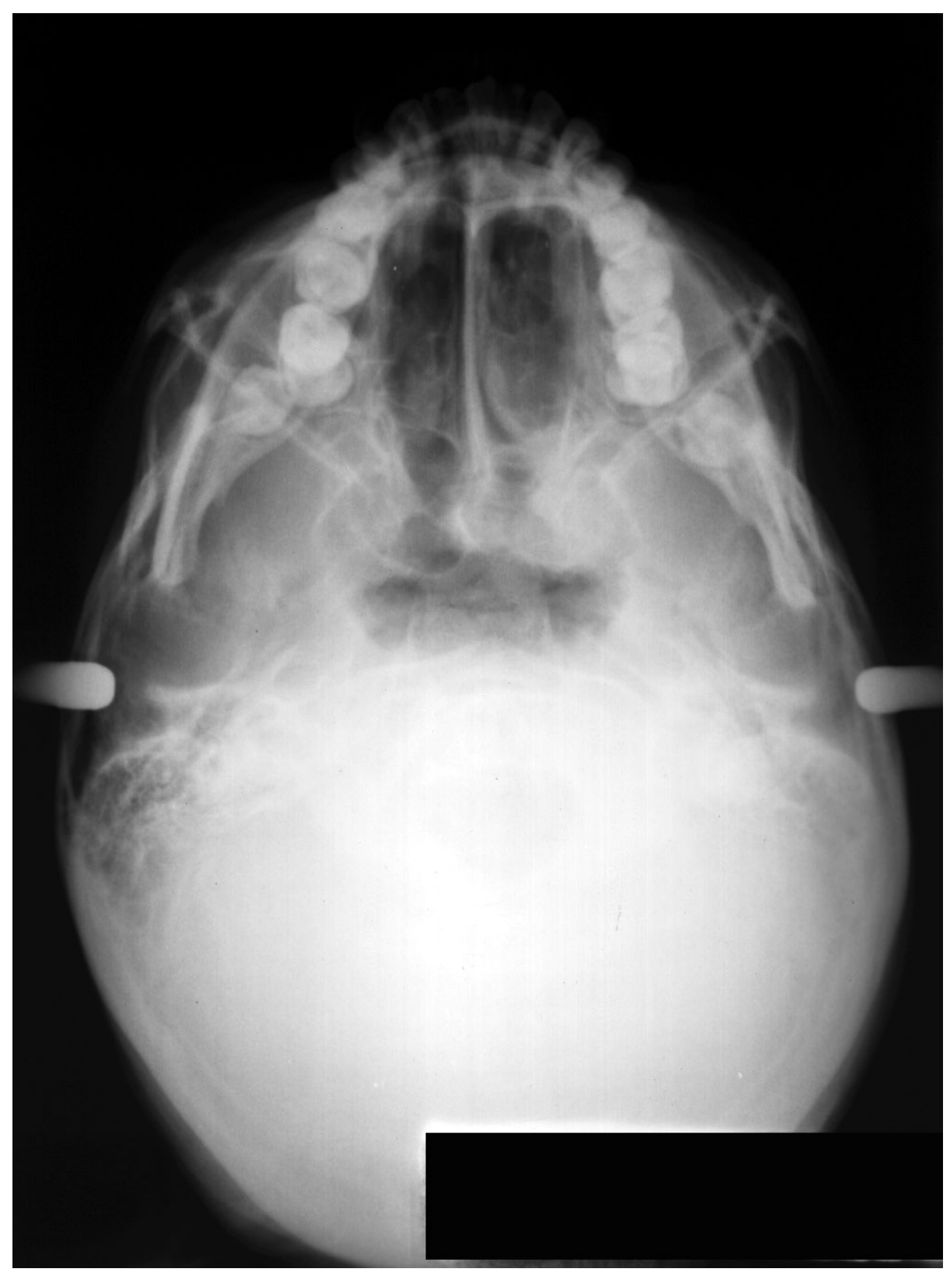

Figura 4.3 - Radiografia submentoniana. 


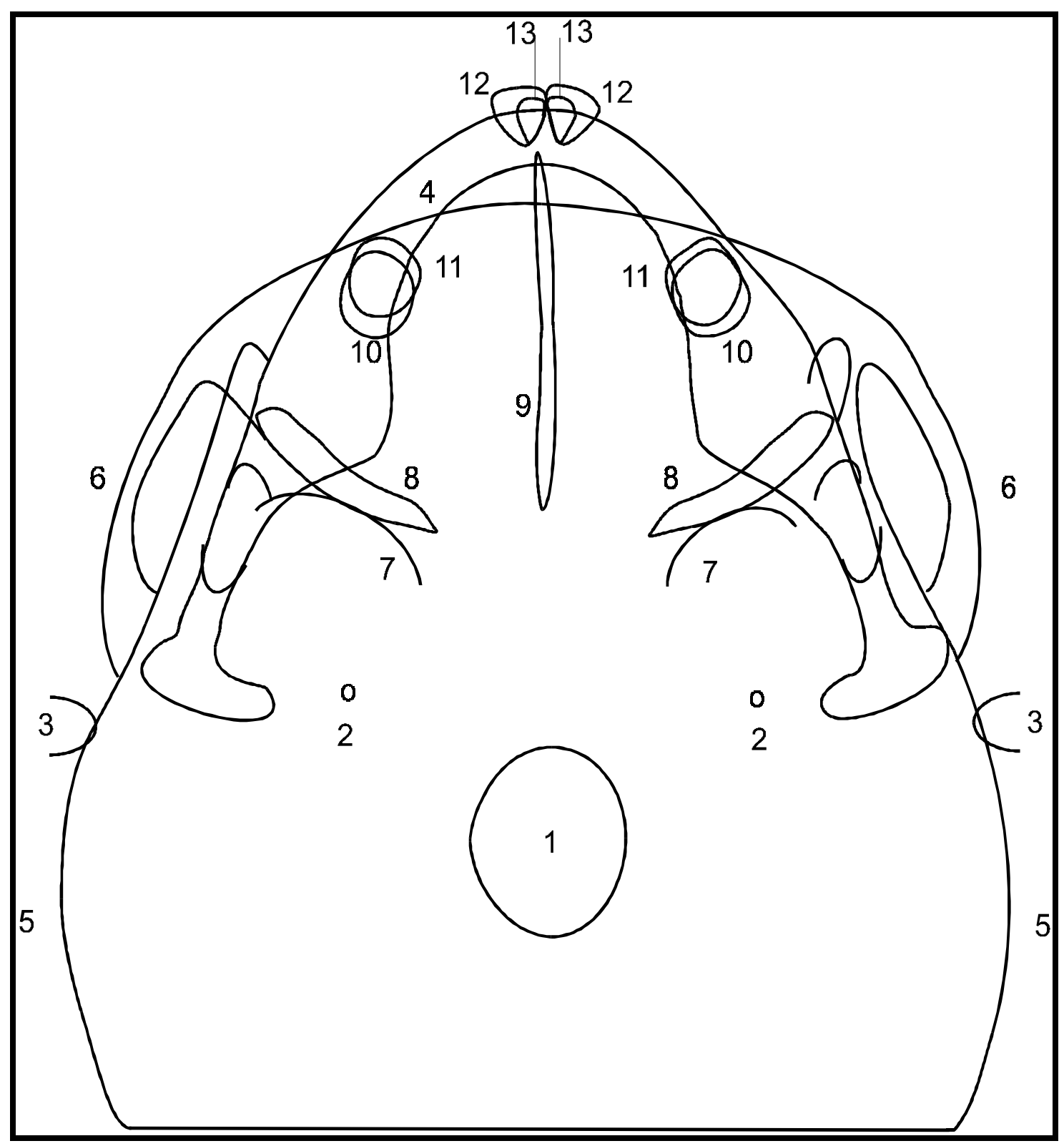

Figura 4.4 - Estruturas anatômicas da radiografia submentoniana*.

${ }^{*}$ Fonte: Figura reproduzida da pesquisa de JANSON ${ }^{65}$. 


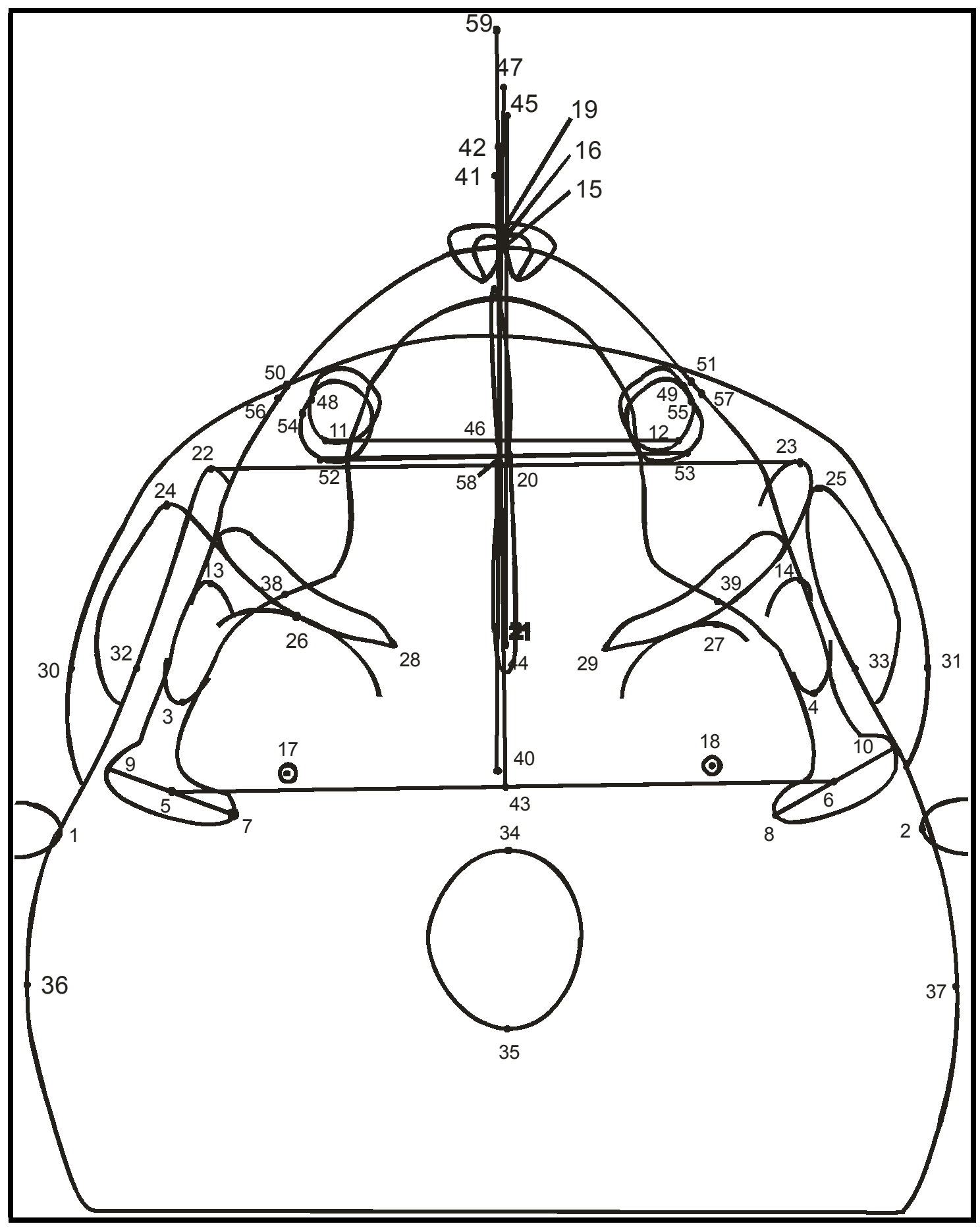

Figura 4.5 - Pontos de referência da radiografia submentoniana*.

${ }^{*}$ Fonte: Figura reproduzida da pesquisa de JANSON ${ }^{65}$. 


\subsubsection{Radiografias oblíquas corrigidas}

Para a obtenção das radiografias oblíquas corrigidas, recorreu-se às radiografias submentonianas ${ }^{11,28,39,52,65,66,80,86,144}$ para que houvesse a possibilidade de mensuração dos ângulos de incidência dos raios $X$, para a projeção paralela para cada lado da cabeça de cada indivíduo. Desta forma, calculou-se a rotação necessária no cefalostato para que cada lado das estruturas ficasse paralelo ao filme. Na radiografia submentoniana, traçou-se o eixo sagital (linha B) perpendicular ao eixo interporiônico (Linha A), passando pela maior sobreposição dos pontos médios dos forames oval e espinhoso, pelo básio e opístio, perpendiculares a uma linha, conectando o ponto médio das olivas metálicas, que é o eixo interporiônico (Linha A) (Figura 4.6). Uma outra linha $C$ foi traçada do ponto médio de cada côndilo até a sínfise. As linhas $X$ e $Z$ foram traçadas, uma de cada lado, perpendiculares à linha $\mathrm{C}$, até a intersecção do plano sagital médio com a linha interporiônica. Os ângulos 1 e 2, formados pelas linhas A e x, e A e z determinaram respectivamente, a rotação necessária no cefalostato, para que o correspondente corpo mandibular ficasse paralelo ao filme, na obtenção das radiografias oblíquas corrigidas (Figura 4.7).

Utilizou-se a seguinte técnica para a obtenção das radiografias oblíquas corrigidas (Figuras 4.8a e 4.8b): cada indivíduo foi posicionado no cefalostato, com o plano de Frankfurt paralelo ao solo ${ }^{12,57}$ e o cefalostato foi rotacionado de acordo com o ângulo obtido na radiografia submentoniana, para projetar os lados esquerdo e direito das estruturas, paralelamente ao filme ${ }^{100}$. O aparelho utilizado foi o ROENTAX $10090^{4}$, com filme Kodak X - OMAT K (não interfoliado) e com tempo de exposição de 1 segundo, 90kvp e 25mA. A distância do ponto focal até às olivas metálicas foi padronizada em $152 \mathrm{~cm}$ e a distância das olivas metálicas até o filme foi fixada em $16 \mathrm{~cm}$, fornecendo um fator de magnificação de 8,91\%. Durante as exposições radiográficas, os indivíduos foram orientados a manter os dentes em máxima intercuspidação habitual. 


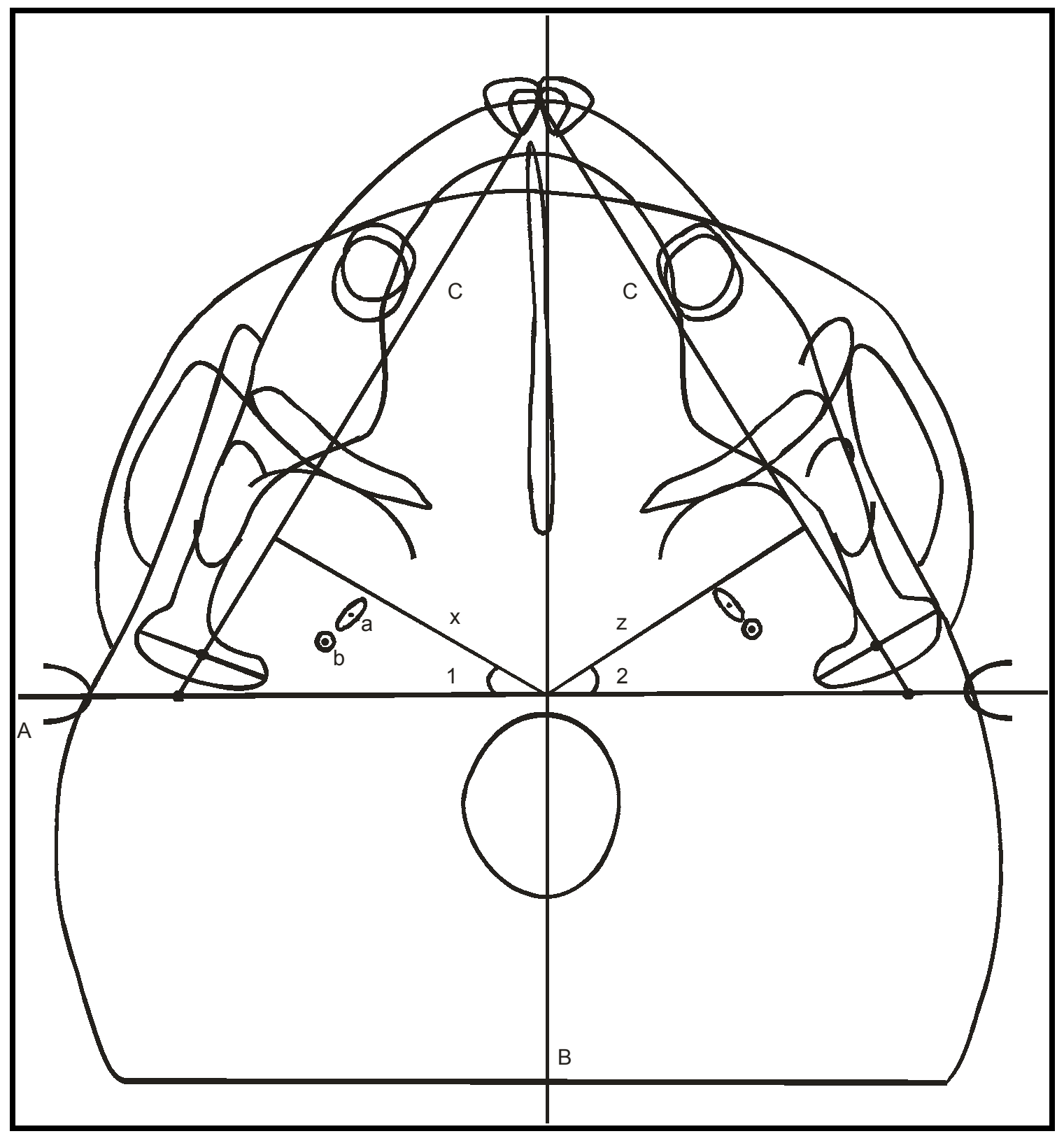

Figura 4.6 - Estruturas anatômicas, pontos de referência, linhas e grandezas cefalométricas utilizadas na radiografia submentoniana para a obtenção das radiografias oblíquas corrigidas. a) forame oval; b) forame espinhoso; 1 . ângulo que determina a rotação do cefalostato para a radiografia oblíqua do lado direito do paciente; 2 . ângulo que determina a rotação do cefalostato para a radiografia oblíqua do lado esquerdo do paciente.

${ }^{*}$ Fonte: Figura reproduzida e modificada da pesquisa de JANSON ${ }^{65}$. 


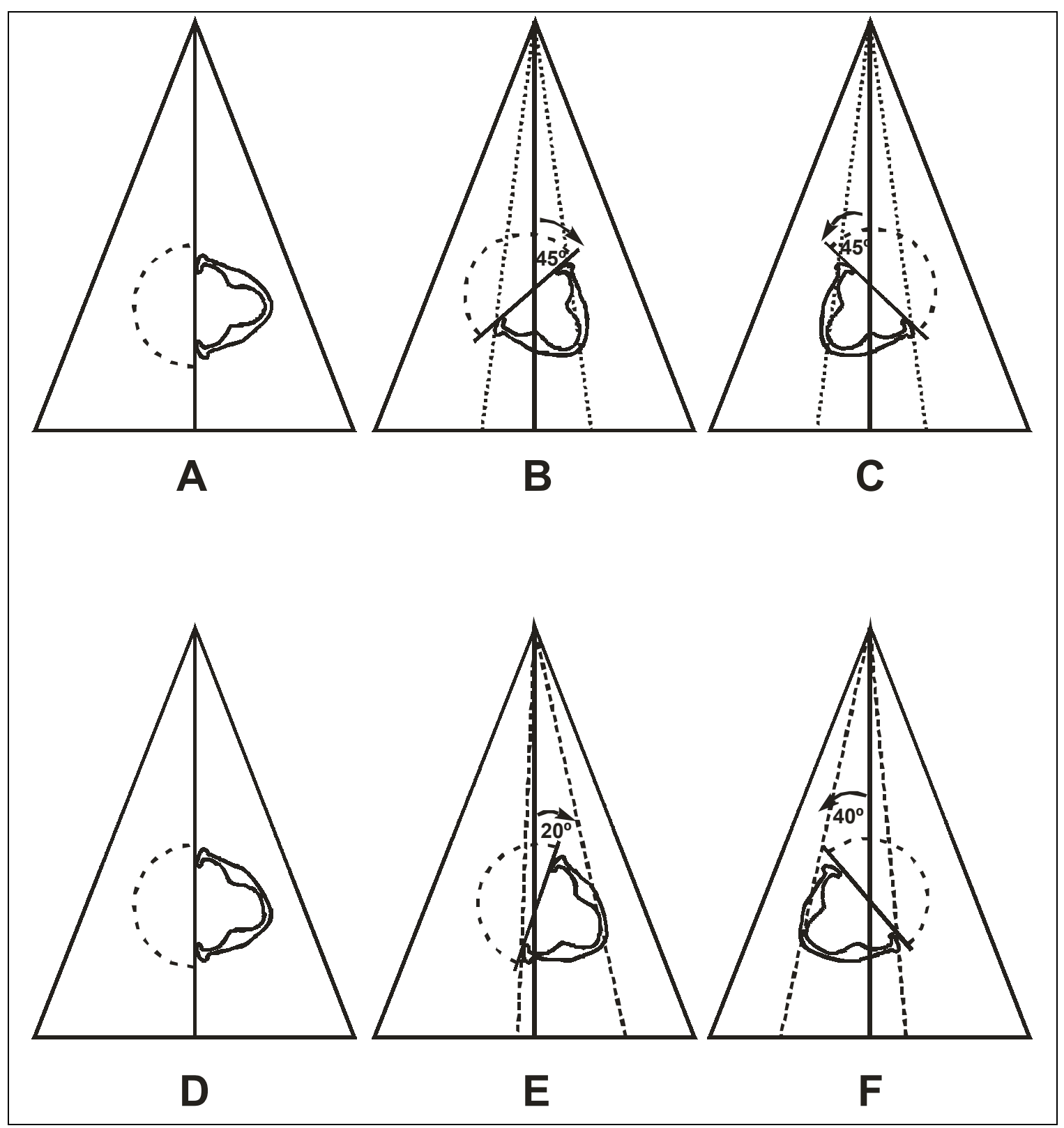

Figura 4.7 - Em A, B e C estão representadas as rotações no cefalostato para a obtenção das radiografias oblíquas a $45^{\circ}$. Em D, E e $F$ estão representadas as rotações no cefalostato para a obtenção das radiografias oblíquas corrigidas.

${ }^{*}$ Fonte: Figura reproduzida e modificada da pesquisa de JANSON ${ }^{65}$. 


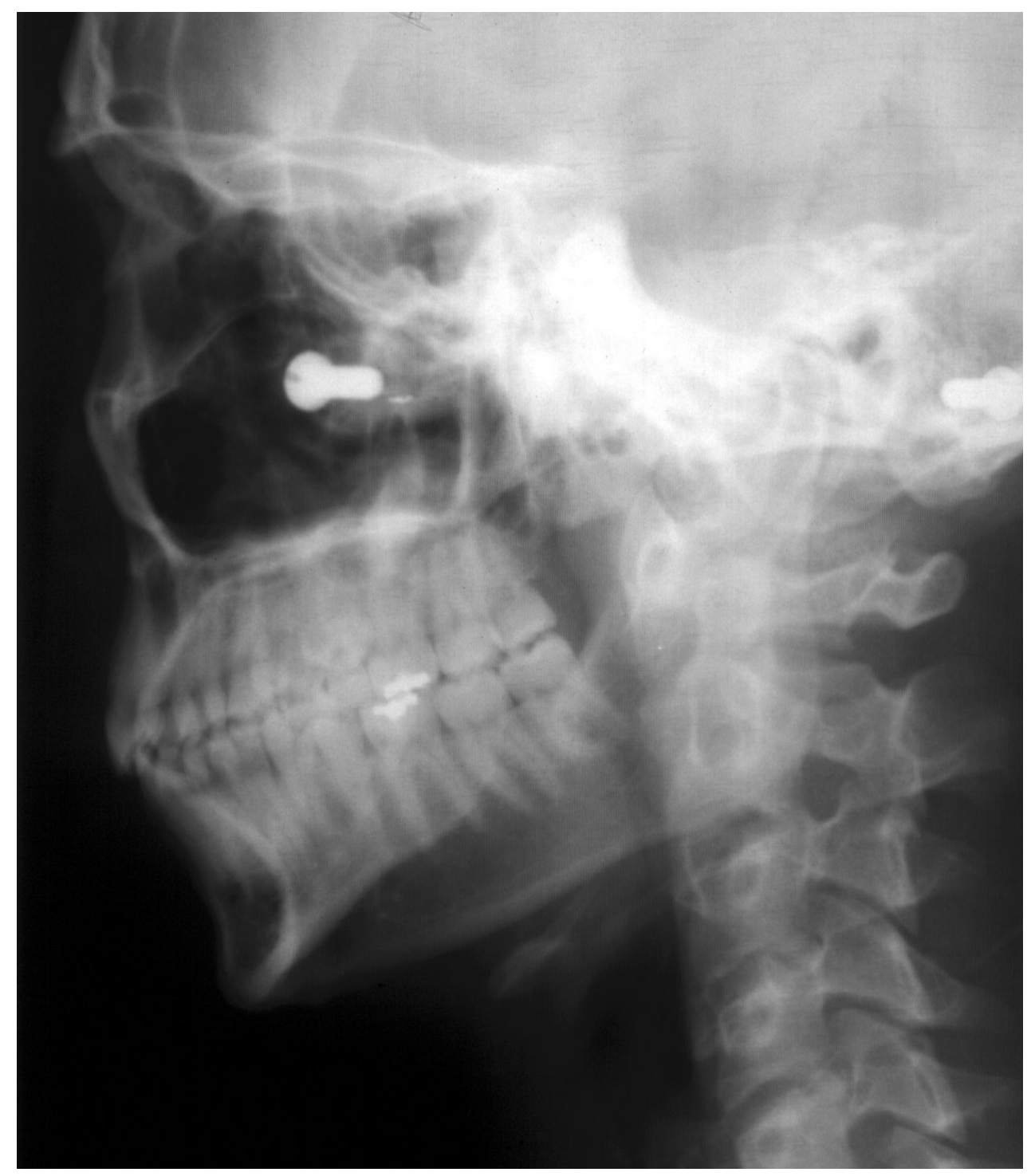

Figura 4.8a - Radiografia oblíqua corrigida (lado direito). 


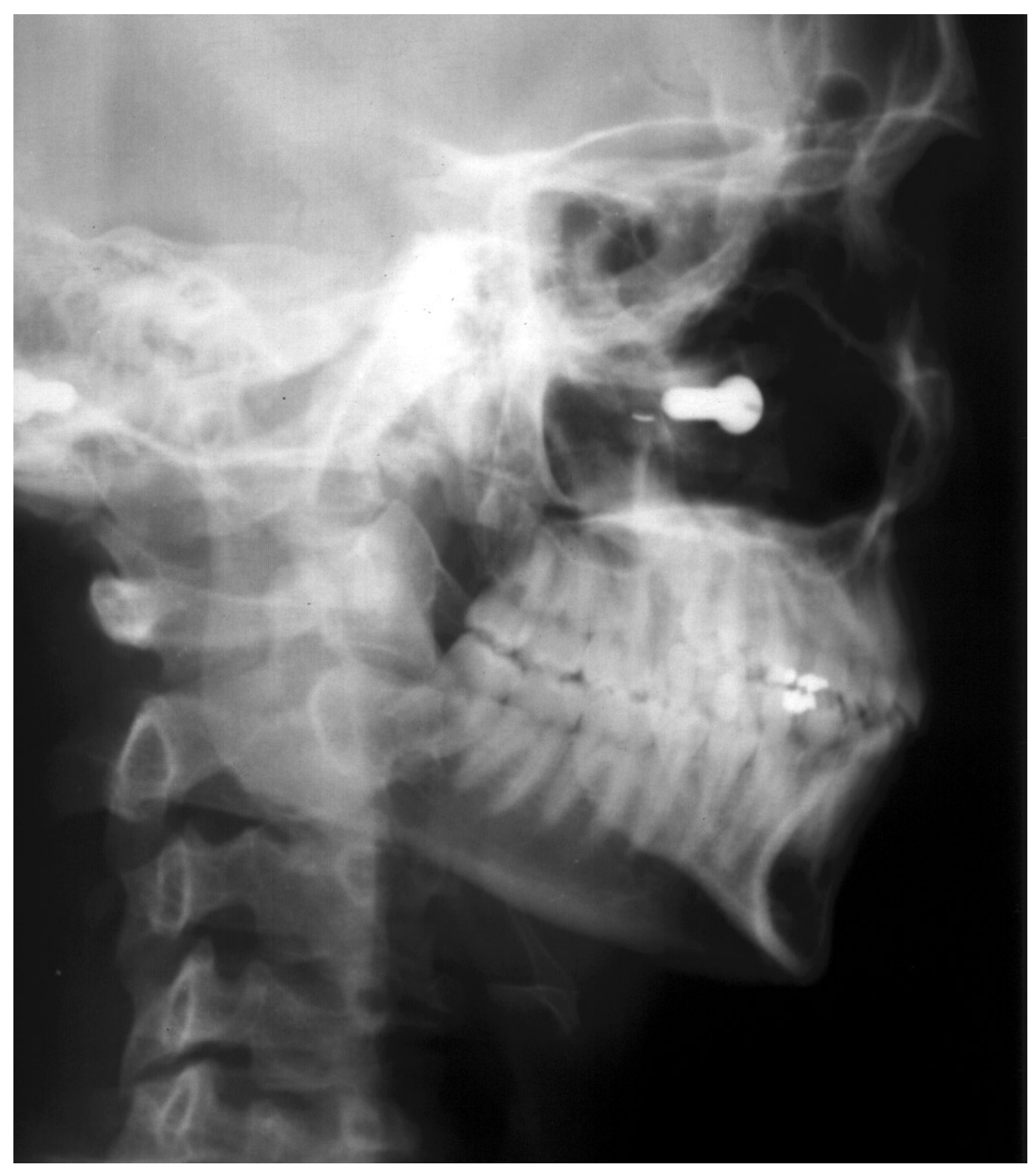

Figura 4.8b - Radiografia oblíqua corrigida (lado esquerdo). 
A delimitação das estruturas anatômicas, a demarcação dos pontos e linhas e a obtenção das grandezas cefalométricas foram realizadas nas radiografias oblíquas corrigidas, dos lados direito e esquerdo, de acordo com BARBER; PRUZANSKY; KINDELSPERGER ${ }^{12}$ (1961); JANSON ${ }^{65}$ (1998); MELNIK ${ }^{98}$ (1992); WOODSIDE ${ }^{191}$ (1968); WOODSIDE; HARVOLD ${ }^{193}$ (1988), com algumas modificações de interesse para o estudo. As figuras 4.9, 4.10 e 4.11 ilustram as estruturas anatômicas, pontos e linhas de referência e grandezas cefalométricas para o lado esquerdo. Para o outro lado, a descrição segue a mesma metodologia, com uma numeração subseqüente, respectivamente, conforme descrito nos pontos de referência citados a seguir.

Em consonância com as metodologias adotadas em trabalhos anteriores $^{11,28,65,86}$, as radiografias submentonianas, oblíquas corrigidas e panorâmicas do grupo de oclusão normal foram sempre posicionadas, com o lado direito do paciente coincidente com o lado esquerdo do observador. Enquanto que as radiografias dos grupos experimentais foram posicionadas de forma que o lado de Classe I estivesse sempre do lado esquerdo do observador, considerando que o profissional se encontrava posicionado à frente do paciente. Realizou-se este procedimento para que o programa de cefalometria calculasse as diferenças entre as medidas bilaterais, subtraindo-se sempre os valores do lado esquerdo, do caso em questão, dos valores do lado direito, nos casos de oclusão normal (grupo 2) e os valores do lado com relação molar de Classe II com os do lado de Classe I, nos grupos experimentais.

Foram utilizados valores absolutos para as diferenças entre as medidas dos lados direito e esquerdo como para as distâncias horizontais aos planos de referência médios. Desta forma, eliminou-se a possibilidade de valores de diferença positivos e negativos se cancelassem no cálculo das médias para cada grupo ${ }^{9}$. Entretanto, os valores reais para cada variável foram calculados para elucidar a direção das assimetrias lineares e angulares, quando estavam presentes. 
A disposição das radiografias, da forma anteriormente mencionada, foi realizada para que as leituras dos valores reais, não fossem influenciadas, entretanto para o cálculo dos valores absolutos, este protocolo poderia ter sido dispensado.

\subsubsection{1- Estruturas anatômicas (Figura 4.9):}

1- Contorno anterior da sínfise.

2- Borda inferior do corpo mandibular.

3- Ramo da mandíbula.

4- Côndilo.

5- Processo coronóide.

6- Altura do osso alveolar.

7- Segundo molar superior.

8- Segundo molar inferior.

9- Terceiro molar superior.

10-Terceiro molar inferior.

11-Primeiro pré-molar inferior.

12-Segundo pré-molar inferior.

13-Incisivo central superior.

14-Incisivo central inferior. 


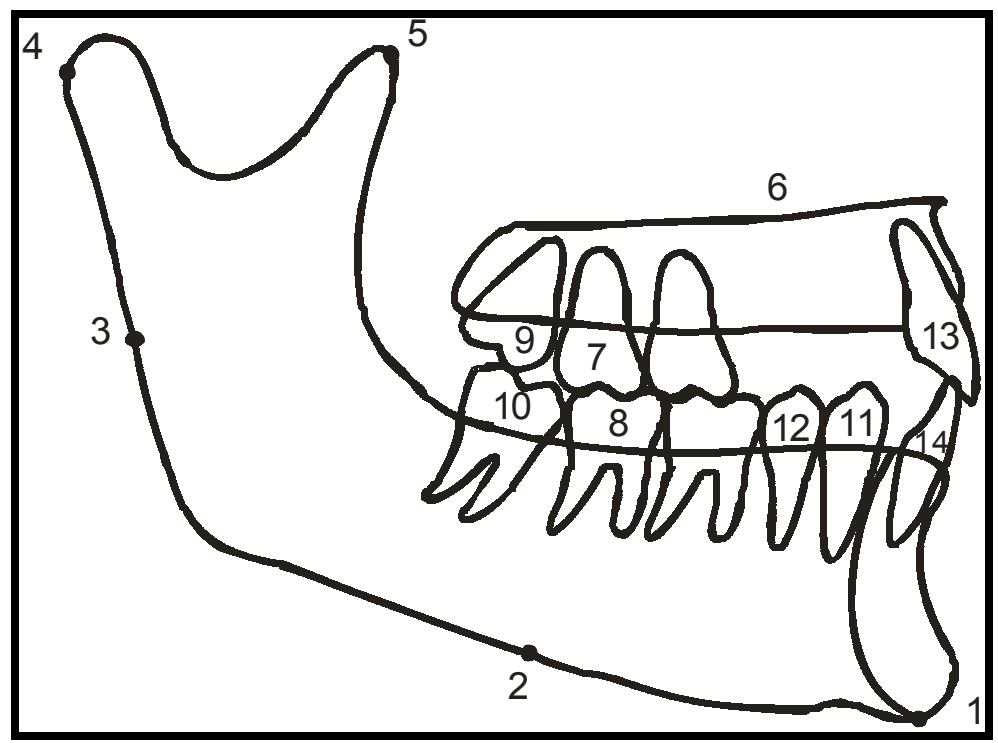

Figura 4.9 - Estruturas anatômicas da radiografia oblíqua corrigida, lado esquerdo.

\subsubsection{2- Pontos de referência (Figura 4.10):}

1 Sínfise (sínfise real): $\operatorname{SIN}^{193}$ - ponto demarcado exatamente na porção mais inferior da sínfise mandibular, no lado esquerdo.

2 Gônio (ponto gônio) - ponto situado na porção mais posterior do corpo da mandíbula, próximo ao gônio esquerdo.

3 POSRAM - intersecção entre plano oclusal, que passa pela ponta de cúspide do segundo pré-molar inferior esquerdo e a cúspide distal do segundo molar inferior esquerdo, e a borda posterior do ramo esquerdo.

4 2PMInf. - ponto situado na ponta de cúspide do segundo pré-molar inferior esquerdo.

52 MInf. - ponto situado na face oclusal na ponta de cúspide distal do segundo molar inferior esquerdo.

6 Dist2MInf. - ponto situado na porção mais saliente da convexidade da face distal do segundo molar inferior esquerdo.

7 Dist2MSup. - ponto situado na porção mais saliente da convexidade da face distal do segundo molar superior esquerdo. 
8 Mesi3Mlnf. - ponto situado na face mesial do terceiro molar inferior esquerdo, na sua porção mais saliente.

9 Dist3MInf. - ponto situado na face distal do terceiro molar inferior esquerdo, na sua porção mais saliente.

10 Mesi3MSup. - ponto situado na face mesial do terceiro molar superior esquerdo, na sua porção mais saliente.

11 Dist3MSup. - ponto situado na face distal do terceiro molar superior esquerdo, na sua porção mais saliente.

12 Sínfise* (Sínfise real) - SIN ${ }^{193}$ - ponto demarcado exatamente na porção mais inferior da sínfise mandibular, no lado direito.

13 Gônio* (Ponto gônio) - ponto situado na porção mais posterior do corpo da mandíbula, próximo ao gônio direito.

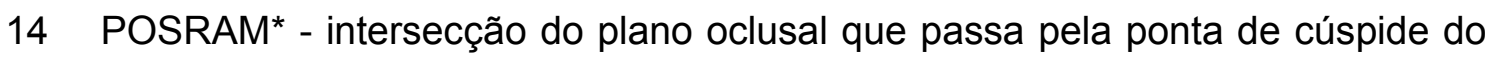
segundo pré-molar inferior direito e a cúspide distal do segundo molar inferior direito, e a borda posterior do ramo, no lado direito.

15 2PMInf. * - ponto situado na ponta de cúspide do segundo pré-molar inferior direito.

16 2Mlnf. * - ponto situado na face oclusal na ponta de cúspide distal do segundo molar inferior direito.

17 Dist2MInf. * - ponto situado na porção mais saliente da convexidade da face distal do segundo molar inferior direito.

18 Dist2MSup. * - ponto situado na porção mais saliente da convexidade da face distal do segundo molar superior direito.

19 Mesi3MInf. * - ponto situado na face mesial do terceiro molar inferior direito, na sua porção mais saliente.

20 Dist3Mlnf. * - ponto situado na face distal do terceiro molar inferior direito, na sua porção mais saliente.

21 Mesi3MSup.* - ponto situado na face mesial do terceiro molar superior direito, na sua porção mais saliente.

22 Dist3MSup. * - ponto situado na face distal do terceiro molar superior direito, na sua porção mais saliente. 
Figura 4.2.2.3- Linhas de referência (Figura 4.10):

- A: plano mandibular esquerdo que passa pelos pontos sínfise e gônio, representando a borda inferior do corpo da mandíbula, no lado esquerdo.

- B: plano oclusal esquerdo que passa pela ponta de cúspide do segundo prémolar inferior esquerdo e a cúspide distal do segundo molar inferior esquerdo, até atingir o limite da borda posterior do ramo da mandíbula, lado esquerdo.

- C: linha do longo eixo do terceiro molar superior esquerdo que passa perpendicularmente ao ponto médio do maior diâmetro mesiodistal do terceiro molar superior esquerdo, passando pelo meio da furca, quando presente.

- D: linha do longo eixo do terceiro molar inferior esquerdo que passa perpendicularmente ao ponto médio do maior diâmetro mesiodistal do terceiro molar inferior esquerdo, passando pelo meio da furca, quando presente.

- $A^{*}$ : plano mandibular direito que passa pelos pontos sínfise e gônio, representando a borda inferior do corpo da mandíbula, lado direito.

- $B^{*}$ : plano oclusal direito que passa pela ponta de cúspide do segundo pré-molar inferior direito e a cúspide distal do segundo molar inferior direito, até atingir o limite da borda posterior do ramo da mandíbula, lado direito.

- $\mathrm{C}^{*}$ : linha do longo eixo do terceiro molar superior direito que passa perpendicularmente ao ponto médio do maior diâmetro mesiodistal do terceiro molar superior direito, passando pelo meio da furca, quando presente.

- $D^{*}$ : linha do longo eixo do terceiro molar inferior direito que passa perpendicularmente ao ponto médio do maior diâmetro mesiodistal do terceiro molar inferior direito, passando pelo meio da furca, quando presente. 


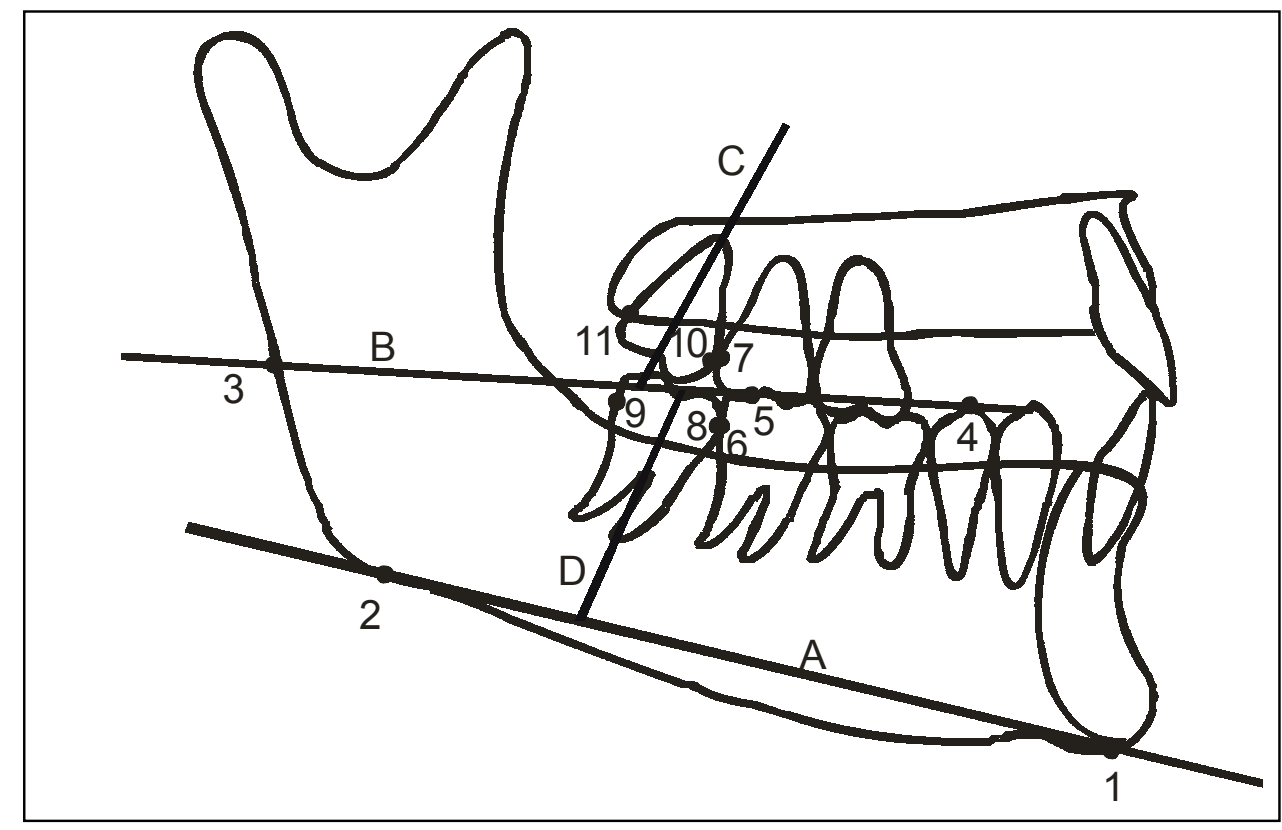

Figura 4.10 - Pontos e linhas de referência da radiografia oblíqua corrigida, lado esquerdo.

\subsubsection{4- Grandezas cefalométricas (Figura 4.11):}

1. Dist2MSE-POSRAM- medida linear referente à distância da face distal do segundo molar superior esquerdo até o ponto POSRAM, do lado esquerdo.

2. Dist2MIE-POSRAM- medida linear referente à distância da face distal do segundo molar inferior esquerdo até o ponto POSRAM, do lado esquerdo.

3. Ang3MSE- medida angular referente ao ângulo do terceiro molar superior esquerdo, obtida a partir da linha formada pelo longo eixo do terceiro molar superior esquerdo com o plano oclusal esquerdo.

4. Ang3MIE- medida angular referente ao ângulo do terceiro molar inferior esquerdo, obtida a partir da linha formada pelo longo eixo do terceiro molar inferior esquerdo com o plano mandibular esquerdo.

5. Dist2MSD-POSRAM- medida linear referente à distância da face distal do segundo molar superior direito até o ponto POSRAM, do lado direito.

6. Dist2MID-POSRAM- medida linear referente à distância da face distal do segundo molar inferior direito até o ponto POSRAM, do lado direito. 
7. Ang3MSD- medida angular referente ao ângulo do terceiro molar superior direito, obtida a partir da linha formada pelo longo eixo do terceiro molar superior direito com o plano oclusal direito.

8. Ang3MID- medida angular referente ao ângulo do terceiro molar inferior direito, obtida a partir da linha formada pelo longo eixo do terceiro molar inferior direito com o plano mandibular direito.

\subsubsection{5- Diferenças entre as medidas bilaterais:}

- Dif2MS-POSRAM- diferença linear do segundo molar superior entre os lados esquerdo e direito até o ponto POSRAM.

- Dif2MI-POSRAM- diferença linear do segundo molar inferior entre os lados esquerdo e direito até o ponto POSRAM.

- DifAng3MS- diferença angular do terceiro molar superior entre os lados esquerdo e direito.

- DifAng3Ml- diferença angular do terceiro molar inferior entre os lados esquerdo e direito.

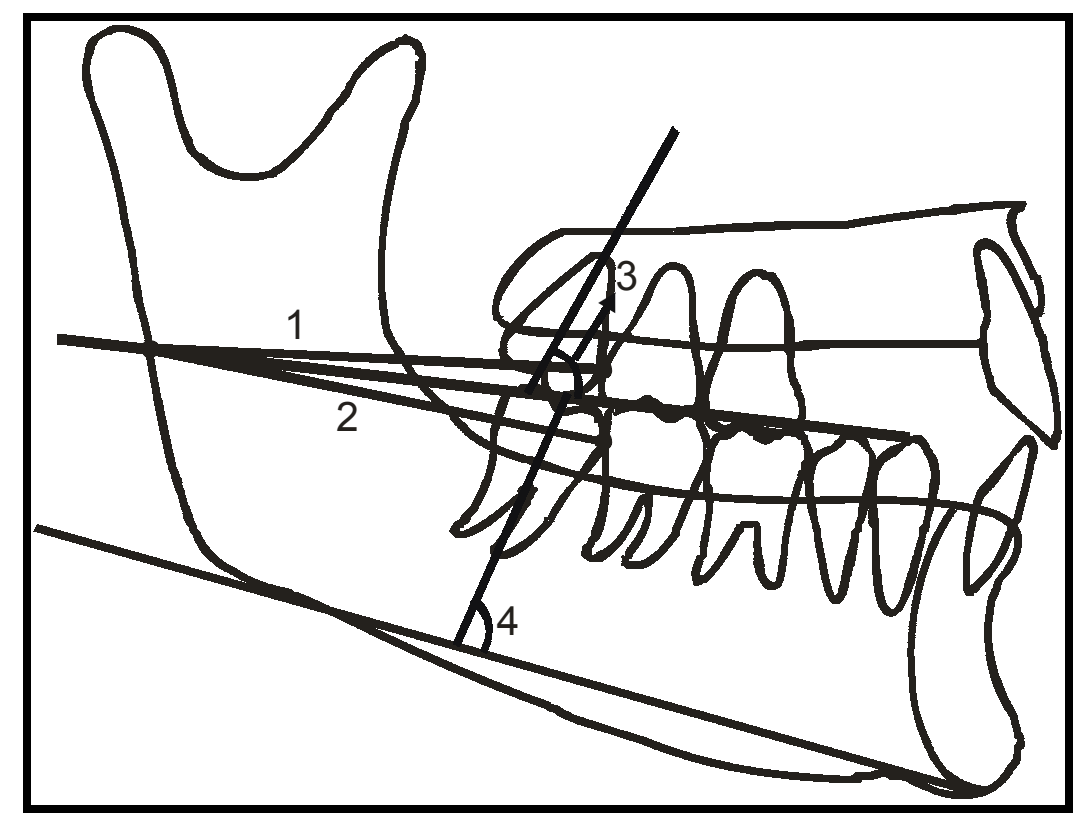

Figura 4.11 - Grandezas cefalométricas da radiografia oblíqua corrigida, lado esquerdo. 


\subsubsection{Radiografias panorâmicas}

Todas as radiografias panorâmicas (Figura 4.12) foram obtidas em um mesmo aparelho, PANEX, modelo $\mathrm{EC}^{5}$, com fator médio de exposição de 90kvp e 15ma. Utilizou-se um chassi plástico flexível com ecran lanex (terras raras), contendo filme radiográfico Kodak - X OMAT, de tamanho $15 \mathrm{~cm} \times 30 \mathrm{~cm}$. A revelação das radiografias foi realizada por meio de processamento automático ${ }^{6}$. Os pacientes foram posicionados corretamente com os planos horizontais de Frankfurt paralelo e plano sagital mediano perpendicular, ambos em relação ao solo ${ }^{2}$, estando os dentes desocluídos com o auxílio de um pedaço de espátula abaixadora de língua, interposto na região anterior.

Para a realização do traçado cefalométrico, adaptou-se em cada película radiográfica uma folha de papel de acetato transparente "ultraphan" de tamanho $14,5 \mathrm{~cm}$, de largura por $21 \mathrm{~cm}$ de comprimento e espessura de $0,07 \mathrm{~mm}$. Os traçados foram realizados sobre o negatoscópio em uma sala escurecida, emoldurados com cartolina preta, expondo-se as áreas correspondentes às estruturas anatômicas de interesse desta pesquisa. Os pontos foram digitalizados para a obtenção das grandezas cefalométricas e, posteriormente, realização das mensurações com o programa Dentofacial Planner $7.0^{7}$. Os traçados das estruturas anatômicas e obtenção dos ângulos de interesse nesta radiografia foram baseados nas metodologias adotadas nos trabalhos de BJERKELIN; KUROL ${ }^{19}$ (1983), PHILIPP; HURST $^{117}$ (1978), TAVANO et al. ${ }^{178}$ (1989) com algumas modificações específicas para este trabalho.

\footnotetext{
${ }^{5} \mathrm{~J}$ Morita Corporation

${ }^{6}$ Processadora Automática da marca Macrotec MX2.

${ }^{7}$ Dentofacial Planner Software Inc., 100 Simcoe Street, Suite 303, Toronto, Ontario, Canadá M5H3G2.
} 


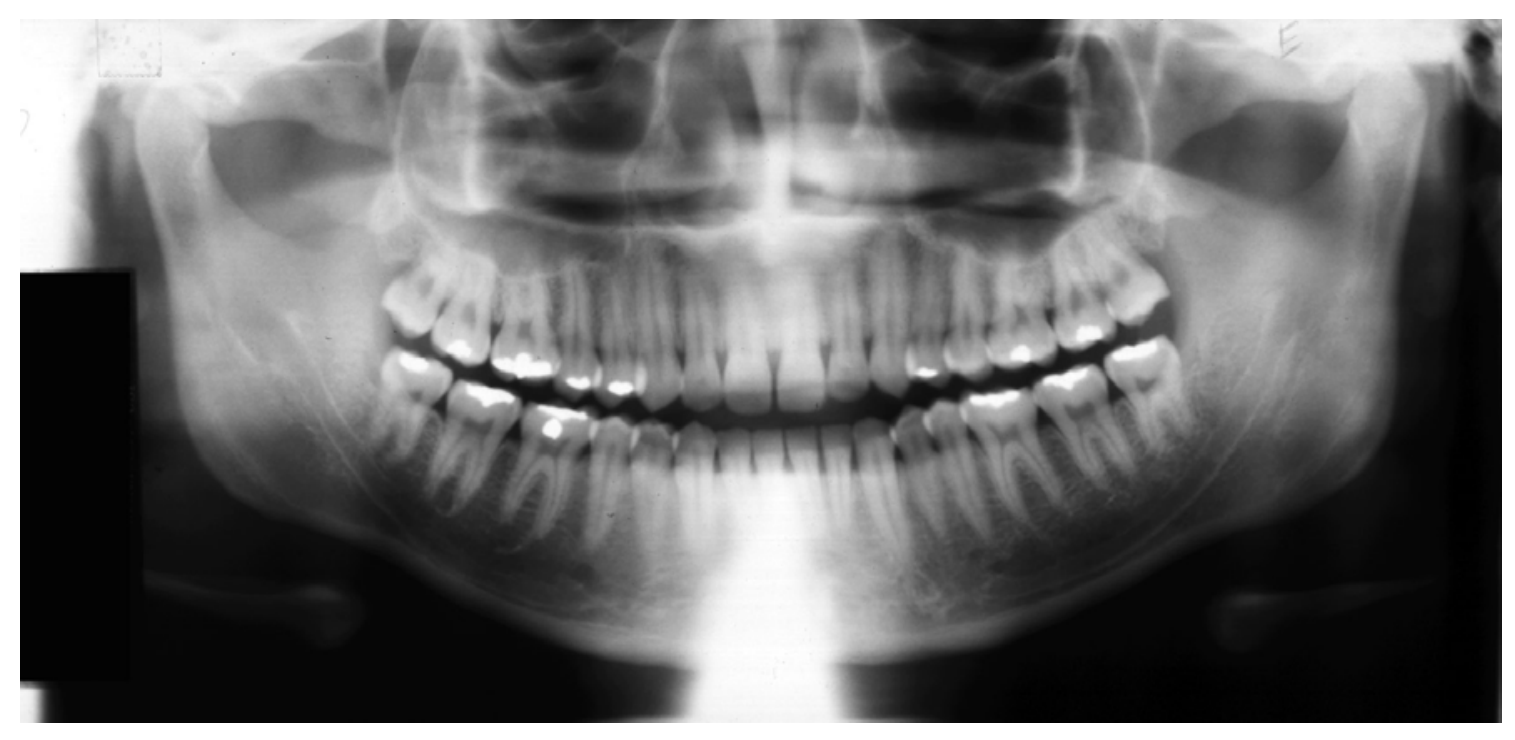

Figura 4.12 - Radiografia panorâmica.

\subsubsection{1- Desenho anatômico das estruturas dentoesqueléticas (Figura 4.13):}

- Limites inferiores das cavidades orbitárias.

- Contorno externo da imagem da mandíbula.

- Forames mentonianos.

- Segundos molares superiores e inferiores.

- Terceiros molares superiores.

- Terceiros molares inferiores.

\subsubsection{2- Pontos de referência (Figura 4.13):}

1. $\mathrm{O}_{\mathrm{rE}}$ (orbital esquerdo) - ponto mais inferior da cavidade orbitária esquerda.

2. $\mathrm{O}_{\mathrm{rD}}$ (orbital direito) - ponto mais inferior da cavidade orbitária direita.

3. FMeE (forame mentoniano esquerdo) - ponto mais central do forame mentoniano esquerdo.

4. FMeD (forame mentoniano direito) - ponto mais central do forame mentoniano direito.

5. 3MSradE - ponto médio situado na porção radicular do terceiro molar superior esquerdo, passando próximo à furca ou ao ápice da raiz, quando presente.

6. $3 \mathrm{MScoroE}$ - ponto médio situado no maior diâmetro mesiodistal da coroa do terceiro molar superior esquerdo. 
7. $3 \mathrm{MSradD}$ - ponto médio situado na porção radicular do terceiro molar superior direito, passando próximo à furca ou ao ápice da raiz, quando presente.

8. $3 \mathrm{MScoroD}$ - ponto médio situado no maior diâmetro mesiodistal da coroa do terceiro molar superior direito.

9. 3MlcoroE - ponto médio situado no maior diâmetro mesiodistal da coroa do terceiro molar inferior esquerdo.

10.3MIradE - ponto médio situado na porção radicular do terceiro molar inferior esquerdo, passando próximo à furca ou ao ápice da raiz, quando presente.

11.3MlcoroD - ponto médio situado no maior diâmetro mesiodistal da coroa do terceiro molar inferior direito.

12.3MlradD - ponto médio situado na porção radicular do terceiro molar inferior direito, passando próximo à furca ou ao ápice da raiz, quando presente.

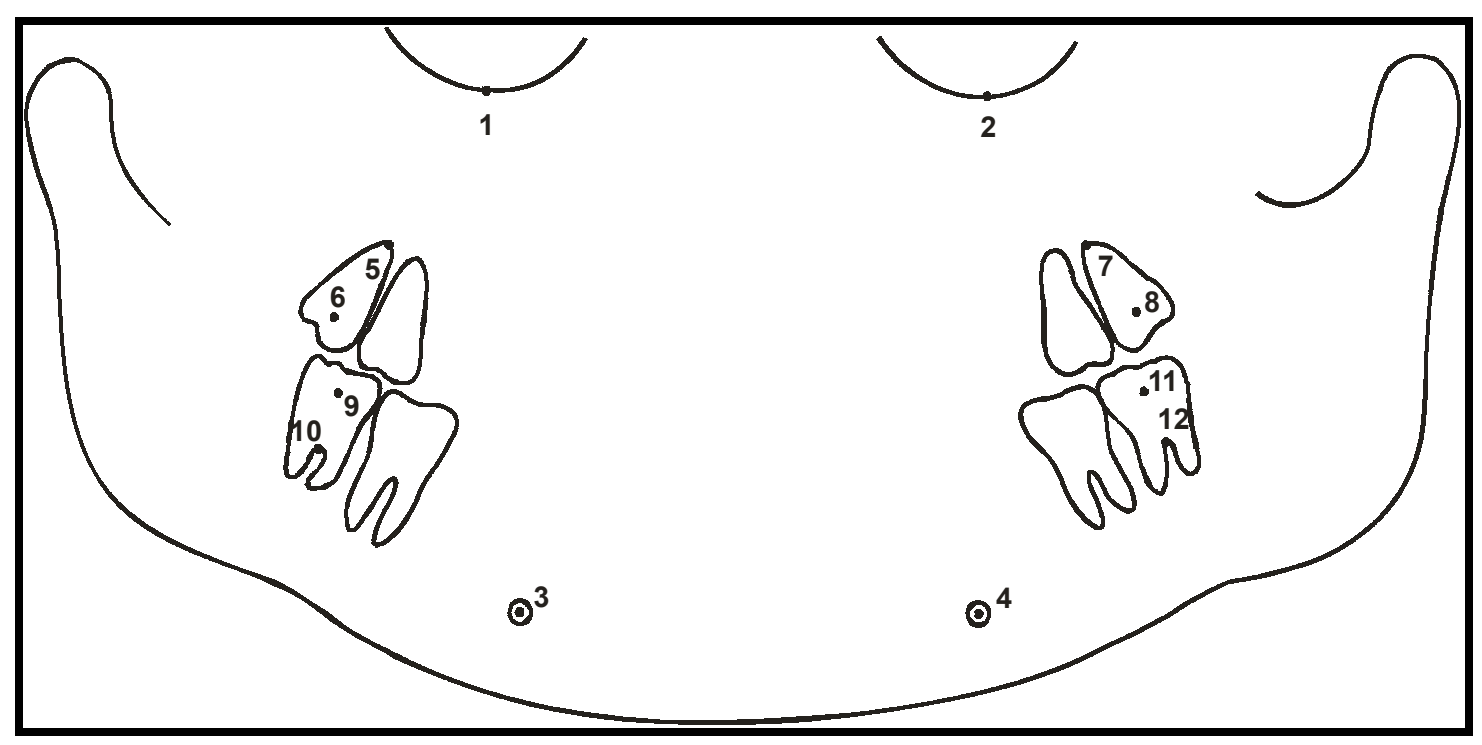

Figura 4.13 - Desenho anatômico das estruturas dentoesqueléticas e pontos de referência da radiografia panorâmica. 


\subsubsection{3- Linhas de referência (Figura 4.14):}

A. Linha Interorbitária $\left(\mathrm{L}_{\mathrm{iOr}}\right)$ - linha horizontal delimitada pelos limites mais inferiores das órbitas, passando pelos pontos 1 e 2 .

B. Linha Intermentoniano $\left(\mathrm{L}_{\mathrm{i} M \mathrm{e}}\right)$ - linha horizontal delimitada pelos centros mediais dos forames mentonianos, passando pelos pontos 3 e 4 .

C. LE3MSE - linha do longo eixo do terceiro molar superior esquerdo que passa pelos pontos 5 e 6

D. LE3MSD - linha do longo eixo do terceiro molar superior direito que passa pelos pontos 7 e 8 .

E. LE3MIE - linha do longo eixo do terceiro molar inferior esquerdo que passa pelos pontos 9 e 10 .

F. LE3MID - linha do longo eixo do terceiro molar inferior direito que passa pelos pontos 11 e 12 .

\subsubsection{4- Grandezas cefalométricas nas radiografias panorâmicas (Figura 4.14):}

1. Ang3MSE - Ângulo formado pelo longo eixo do terceiro molar superior esquerdo com a linha interorbitária.

2. Ang3MSD - Ângulo formado pelo longo eixo do terceiro molar superior direito com a linha interorbitária.

3. Ang3MIE - Ângulo formado pelo longo eixo do terceiro molar inferior esquerdo com a linha intermentoniano.

4. Ang3MID - Ângulo formado pelo longo eixo do terceiro molar inferior direito com a linha intermentoniano.

\subsubsection{5- Diferenças entre as medidas bilaterais:}

- DifSubONSup - Diferença angular do terceiro molar superior entre os lados esquerdo e direito.

- DifSubONInf - Diferença angular do terceiro molar inferior entre os lados do esquerdo e direito. 


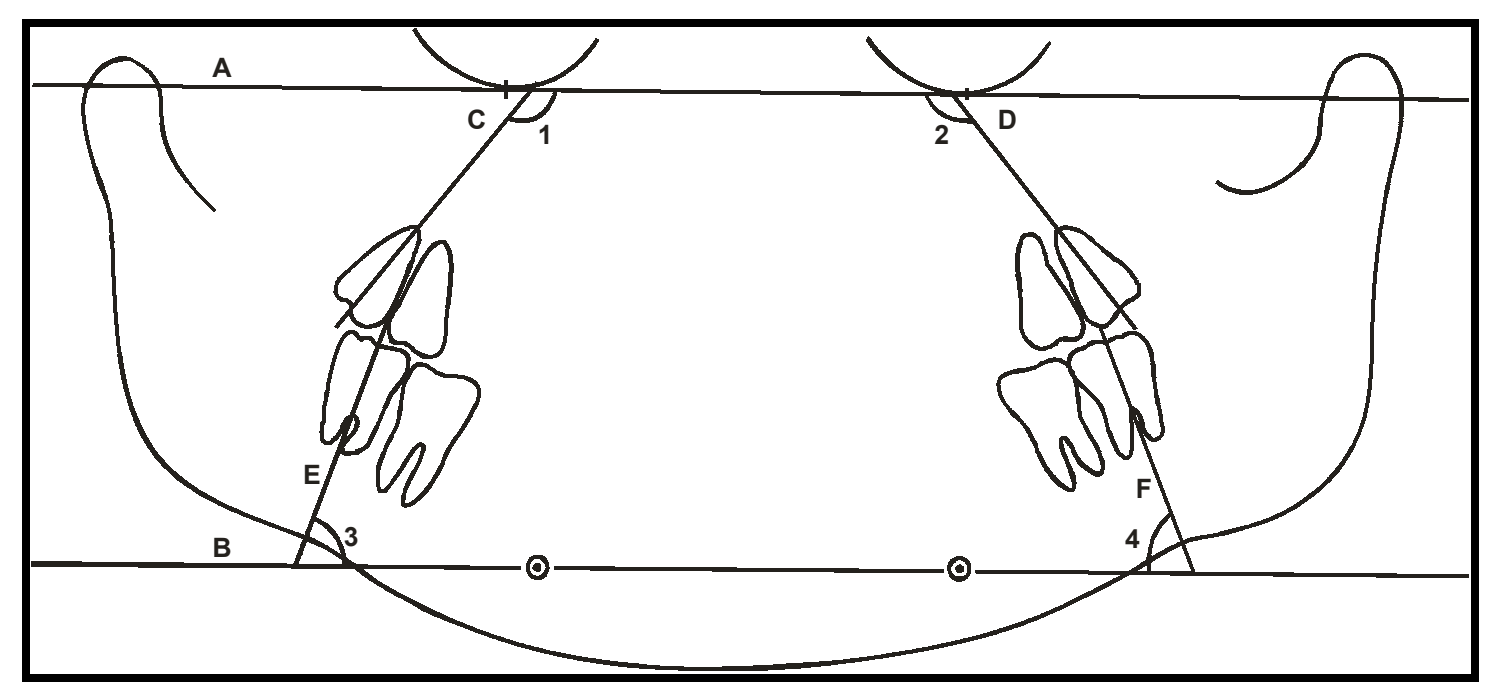

Figura 4.14 - Linhas de referência e grandezas cefalométricas da radiografia panorâmica. 


\subsection{ANÁLISE ESTATÍSTICA}

\subsection{1- Erro do Método}

Para se efetuar o erro do método, foram retraçadas, redigitalizadas e medidas novamente as radiografias oblíquas corrigidas e panorâmicas de 15 pacientes, selecionados aleatoriamente, após um mês do término dos primeiros traçados, num total de 45 radiografias. A mesma examinadora procedeu às mensurações destas repetições tanto para o erro casual como para o sistemático. O erro casual foi estimado pelo cálculo da variância (Se) em cada uma das variáveis pesquisadas entre as mensurações iniciais e repetidas dos 15 pacientes selecionados ao acaso. Para tanto, empregou-se a fórmula proposta por DAHLBERG ${ }^{31}(1940)\left(S_{e}{ }^{2}=\sum d^{2} /\right.$ $2 n$ ), sendo "d" representado pela diferença entre os valores medidos na primeira e na segunda mensuração de cada uma das radiografias selecionadas ao acaso, e " $n$ " refere-se ao número de casos em que as medidas forem repetidas. A obtenção dos erros sistemáticos procedeu-se pela aplicação do teste t pareado $(p<0,05)$ de acordo com BAUMRIND; FRANTZ ${ }^{13}$ (1971), RICHARDSON ${ }^{129}$ (1981), HOUSTON ${ }^{61}$ (1983) e $Z^{2} R^{195}$ (1996). Os valores das mensurações repetidas de cada variável encontramse nos apêndices e os resultados da estatística nas tabelas 1 e 2.

\subsection{2- Testes Estatísticos Utilizados ${ }^{186}$}

Os testes t pareados foram utilizados para as comparações entre os lados dos grupos experimentais e do grupo controle individualmente, nas duas radiografias analisadas. Com o objetivo de comparar as assimetrias lineares e angulares dos terceiros molares dos grupos experimentais com o grupo controle foram realizados os testes $t$ independentes, tanto para as radiografias oblíquas corrigidas como para as panorâmicas. Para a utilização dos testes t, tornou-se necessária a realização prévia da análise da distribuição normal das variáveis que foi avaliada pelo teste de Kolmogorov-Smirnov, para cada uma das variáveis. Em todos os testes realizados, os resultados foram considerados estatisticamente significantes para $p<0,05$. Todas estas análises foram realizadas com o programa Statistica $5.0^{8}$, em um computador Pentium III 800mhz.

\footnotetext{
${ }^{8}$ Statistica for Windows - Release 4.3B. - Copywright Statsoft, Inc. 1993.
} 


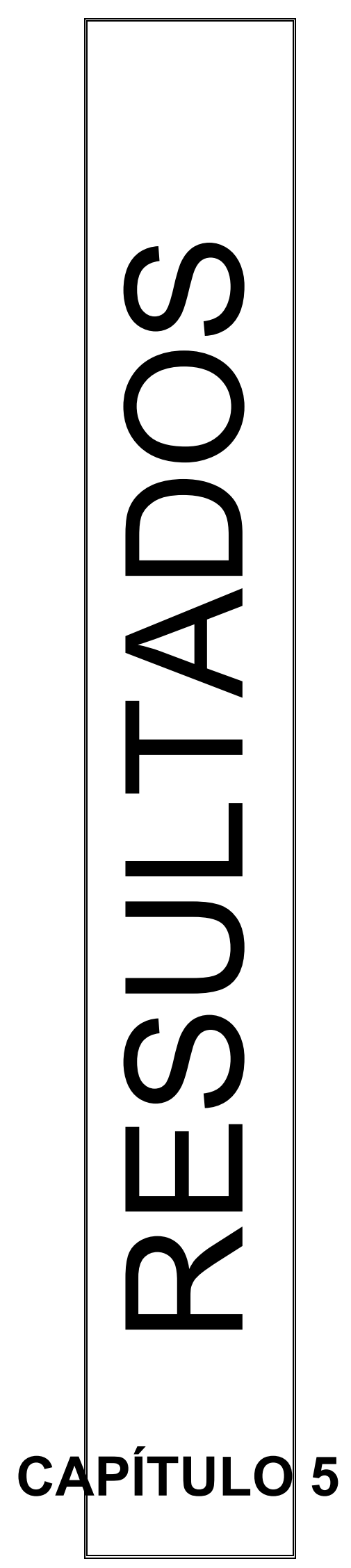




\section{RESULTADOS}

\section{1 apresentação dos resultados encontra-se organizada em tabelas} ordenadas a seguir. As tabelas de 1 a 2 referem-se aos resultados do erro do método nas radiografias oblíquas corrigidas e panorâmicas respectivamente. As tabelas 3 a 8 referem-se aos testes de Kolmogorov-Smirnov de distribuição de normalidade da amostra. A tabela 9 apresenta os resultados dos testes t pareados, para as radiografias oblíquas corrigidas, entre os lados de Classe I e Classe II do Grupo 1 (Classe II, subdivisão). A tabela 10 apresenta os resultados dos testes t pareados entre os lados esquerdo e direito do Grupo 2 (oclusão normal). A tabela 11 apresenta os resultados do teste $t$ independente para as comparações das assimetrias lineares e angulares entre os Grupos 1 e 2. Os resultados das radiografias panorâmicas estão representados da seguinte forma: tabela 12 representa os resultados dos testes t pareados entre os lados de Classe I e Classe II do Grupo 1 (Classe II, subdivisão); tabela 13 representa os resultados dos testes $\mathrm{t}$ pareados entre os lados esquerdo e direito do Grupo 2 (oclusão normal); a tabela 14 representa os resultados do teste $t$ independente para a comparação entre as assimetrias lineares e angulares entre os Grupos 1 e 2.

A tabela 15 apresenta os resultados dos testes $t$ pareados para as comparação entre os lados do subgrupo Tipo 1 e a tabela 16 representa os resultados do teste $\mathrm{t}$ independente para as comparações das diferenças entre os lados do subgrupo Tipo $1 \mathrm{com}$ as diferenças entre os lados do Grupo 2, nas radiografias oblíquas corrigidas. Nas radiografias panorâmicas, a tabela 17 representa os resultados dos testes t pareados das comparações entre os lados do subgrupo Tipo 1 e a tabela 18 representa os resultados do teste $t$ independente das comparações das diferenças entre os lados do subgrupo Tipo $1 \mathrm{com}$ as diferenças entre os lados do Grupo 2 - oclusão normal.

A tabela 19 apresenta os resultados dos testes $t$ pareados da comparação entre os lados do subgrupo Tipo 2 e a tabela 20 representa os resultados do teste $t$ 
independente das comparações das diferenças entre os lados do subgrupo Tipo 2 com as diferenças entre os lados do Grupo 2 - oclusão normal, nas radiografias oblíquas corrigidas. A tabela 21 representa os resultados dos testes t pareados das comparações entre os lados de Classe I e Classe II do subgrupo Tipo 2 e a tabela 22 representa os resultados do teste $t$ independente das comparações das assimetrias angulares entre os lados do subgrupo Tipo $2 \mathrm{com}$ as diferenças entre os lados do Grupo 2, nas radiografias panorâmicas.

Em todas as tabelas apresentadas neste capítulo, os resultados assinalados em vermelho demonstram diferença estatisticamente significante para $p<0,05$. 
Análise intra-examinadora da precisão da metodologia empregada: apresentação dos erros casuais (índice de Dahlberg); média e desvios padrão (D.P.) das diferenças e nível de significância estatística (p) dos valores obtidos das duas séries de traçados realizados para as radiografias oblíquas corrigidas e panorâmicas dos 15 pacientes selecionados aleatoriamente.

Tabela 1 - Resultados do erro do método para as radiografias oblíquas corrigidas.

\begin{tabular}{|c|c|c|c|c|}
\hline VARIÁVEIS & DAHLBERG & $\begin{array}{c}\text { MÉDIA } \\
\text { DIFERENÇA }\end{array}$ & $\begin{array}{c}\text { D.P. } \\
\text { DIFERENÇA }\end{array}$ & $\mathbf{p}$ \\
\hline \multicolumn{5}{|c|}{ Medidas Lineares } \\
\hline $\begin{array}{l}\text { Dist2MSE- } \\
\text { POSRAM }\end{array}$ & 0,76 & $-0,43$ & 1,03 & 0,126 \\
\hline $\begin{array}{l}\text { Dist2MSD- } \\
\text { POSRAM }\end{array}$ & 0,65 & 0,06 & 0,96 & 0,792 \\
\hline $\begin{array}{l}\text { Dist2MIE- } \\
\text { POSRAM }\end{array}$ & 0,74 & $-0,20$ & 1,06 & 0,479 \\
\hline $\begin{array}{l}\text { Dist2MID- } \\
\text { POSRAM }\end{array}$ & 0,64 & 0,20 & 0,91 & 0,395 \\
\hline \multicolumn{5}{|c|}{ Medidas Angulares } \\
\hline Ang3MSE & 1,17 & 0,23 & 1,69 & 0,603 \\
\hline Ang3MSD & 1,19 & 0,73 & 1,56 & 0,091 \\
\hline Ang3MIE & 1,00 & 0,36 & 1,42 & 0,334 \\
\hline Ang3MID & 1,04 & $-0,20$ & 1,52 & 0,618 \\
\hline
\end{tabular}

Tabela 2 - Resultados do erro do método para as radiografias panorâmicas.

\begin{tabular}{|c|c|c|c|c|}
\hline VARIÁVEIS & DAHLBERG & $\begin{array}{c}\text { MÉDIA } \\
\text { DIFERENÇA }\end{array}$ & $\begin{array}{c}\text { D.P. } \\
\text { DIFERENÇA }\end{array}$ & $\mathbf{p}$ \\
\hline \multicolumn{5}{|c|}{ Medidas Angulares } \\
\hline Ang3MSE & 1,06 & $-0,11$ & 1,56 & 0,782 \\
\hline Ang3MSD & 1,60 & $-0,08$ & 2,34 & 0,888 \\
\hline Ang3MIE & 1,69 & $-0,09$ & 2,48 & 0,886 \\
\hline Ang3MID & 1,37 & 0,08 & 2,00 & 0,869 \\
\hline
\end{tabular}


Teste de normalidade da amostra (Kolmogorov-Smirnov)

\section{RADIOGRAFIAS OBLÍQUAS CORRIGIDAS}

Tabela 3 - Resultados do teste de normalidade para o Grupo 1 (Classe II, subdivisão).

\begin{tabular}{l|c|c|c|c}
\hline \multirow{2}{*}{ VARIÁVEIS } & \multicolumn{4}{|c}{ Grupo 1 (Classe II, subdivisão) } \\
\cline { 2 - 5 } & \multicolumn{2}{|c}{ Lado de Classe I } & \multicolumn{2}{c}{ Lado de Classe II } \\
\cline { 2 - 5 } & K-S (d) & $\mathbf{p}$ & K-S (d) & $\mathbf{p}$ \\
\hline Dist2MS- & 0,135 & $>0,20$ & 0,136 & $>0,20$ \\
POSRAM & 0,107 & $>0,20$ & 0,179 & $>0,20$ \\
\hline Dist2MI- & 0,121 & $>0,20$ & 0,093 & $>0,20$ \\
POSRAM & Ang3MSup. & $<0,15$ & 0,136 & $>0,20$ \\
\hline Ang3MInf. & 0,218 & $<$
\end{tabular}

Tabela 4 - Resultados do teste de normalidade para o Grupo 2 (oclusão normal).

\begin{tabular}{l|c|c|c|c}
\hline \multirow{2}{*}{ VARIÁVEIS } & \multicolumn{4}{|c}{ Grupo 2 (oclusão normal) } \\
\cline { 2 - 5 } & \multicolumn{2}{|c}{ Lado Esquerdo } & \multicolumn{2}{c}{ Lado Direito } \\
\cline { 2 - 5 } & K-S (d) & $\mathbf{p}$ & $\mathbf{K}-\mathbf{S}$ (d) & $\mathbf{p}$ \\
\hline Dist2MS- & 0,215 & $>0,20$ & 0,217 & $>0,20$ \\
POSRAM & & $>0,20$ & 0,192 & $>0,20$ \\
\hline Dist2MI- & 0,211 & $>0,20$ & 0,200 & $>0,20$ \\
POSRAM & 0,112 & $>0,20$ & 0,219 & $>0,20$ \\
\hline Ang3MSup. & 0,111 & \multicolumn{3}{c}{} \\
\hline Ang3MInf. & \multicolumn{4}{c}{}
\end{tabular}

Tabela 5 - Resultados do teste de normalidade das assimetrias lineares e angulares entre os lados de Classe I e Classe II do Grupo 1 (Classe II, subdivisão) e entre os lados esquerdo e direito do Grupo 2 (oclusão normal).

\begin{tabular}{l|c|c|c|c}
\hline \multirow{2}{*}{ VARIÁVEIS } & \multicolumn{2}{|c|}{$\begin{array}{c}\text { Classe II, subdivisão } \\
\text { Grupo 1 }\end{array}$} & \multicolumn{2}{c}{$\begin{array}{c}\text { Oclusão Normal } \\
\text { Grupo 2 }\end{array}$} \\
\cline { 2 - 5 } & K-S (d) & $\mathbf{p}$ & K-S (d) & p \\
\hline Dif2MS-POSRAM & 0,222 & $<0,10$ & 0,264 & $<0,20$ \\
\hline Dif2MI-POSRAM & 0,129 & $>0,20$ & 0,195 & $>0,20$ \\
\hline DifAngMSUup. & 0,245 & $<0,05$ & 0,181 & $>0,20$ \\
\hline DifAng3MInf. & 0,178 & $>0,20$ & 0,187 & $>0,20$ \\
\hline
\end{tabular}




\section{RADIOGRAFIAS PANORÂMICAS}

Tabela 6 - Resultados do teste de normalidade para o Grupo 1 (Classe II, subdivisão).

\begin{tabular}{l|c|c|c|c}
\hline \multirow{2}{*}{ VARIÁVEIS } & \multicolumn{4}{|c}{ Grupo 1 (Classe II, subdivisão) } \\
\cline { 2 - 5 } & \multicolumn{2}{|c}{ Lado de Classe I } & \multicolumn{2}{c}{ Lado de Classe II } \\
\cline { 2 - 5 } & $\mathbf{K - S}$ (d) & $\mathbf{p}$ & K-S (d) & $\mathbf{p}$ \\
\hline Ang3MSup. & 0,105 & $>0,20$ & 0,143 & $>0,20$ \\
\hline Ang3MInf. & 0,167 & $>0,20$ & 0,132 & $>0,20$ \\
\hline
\end{tabular}

Tabela 7 - Resultados do teste de normalidade para o Grupo 2 (oclusão normal).

\begin{tabular}{l|c|c|c|c}
\hline \multirow{2}{*}{ VARIÁVEIS } & \multicolumn{4}{|c}{ Grupo 2 (Oclusão Normal) } \\
\cline { 2 - 5 } & K-S (d) & $\mathbf{p}$ & K-S (d) & $\mathbf{p}$ \\
\hline Ang3MSup. & 0,095 & $>0,20$ & 0,158 & $>0,20$ \\
\hline Ang3MInf. & 0,137 & $>0,20$ & 0,145 & $>0,20$ \\
\hline
\end{tabular}

Tabela 8 - Resultados do teste de normalidade das assimetrias angulares entre os lados de Classe I e Classe II do Grupo 1 (Classe II, subdivisão) e entre os lados esquerdo e direito do Grupo 2 (oclusão normal).

\begin{tabular}{l|c|c|c|c}
\hline \multirow{2}{*}{ VARIÁVEIS } & \multicolumn{2}{|c|}{$\begin{array}{c}\text { Classe II, subdivisão } \\
\text { Grupo 1 }\end{array}$} & \multicolumn{2}{c}{$\begin{array}{c}\text { Oclusão Normal } \\
\text { Grupo 2 }\end{array}$} \\
\cline { 2 - 5 } & K-S (d) & $\mathbf{p}$ & K-S (d) & $\mathbf{p}$ \\
\hline DifAng3MSup. & 0,185 & $>0,20$ & 0,261 & $<0,20$ \\
\hline DifAng3MInf. & 0,229 & $<0,10$ & 0,113 & $>0,20$ \\
\hline
\end{tabular}




\section{RESULTADOS DO GRUPO DE CLASSE II, SUBDIVISÃO}

RADIOGRAFIAS OBLÍQUAS CORRIGIDAS

Tabela 9 - Resultados dos testes $t$ pareados da comparação entre os lados de Classe I e Classe II do Grupo 1 (Classe II, subdivisão).

\begin{tabular}{|c|c|c|c|c|c|c|c|c|c|}
\hline \multirow{3}{*}{ VARIÁVEIS } & \multicolumn{4}{|c|}{ Classe II, subdivisão - (Grupo 1) } & \multirow{3}{*}{$\begin{array}{c}\text { Valor } \\
\mathrm{t}\end{array}$} & \multirow{3}{*}{ G.L. } & \multirow{3}{*}{ Dif. } & \multirow{3}{*}{$\begin{array}{l}\text { D.P. } \\
\text { Dif. }\end{array}$} & \multirow{3}{*}{$\mathrm{p}$} \\
\hline & \multicolumn{2}{|c|}{ Lado de Classe I } & \multicolumn{2}{|c|}{ Lado de Classe II } & & & & & \\
\hline & Média & D.P. & Média & D.P. & & & & & \\
\hline \multicolumn{10}{|c|}{ Medidas Lineares } \\
\hline $\begin{array}{l}\text { Dist2MS- } \\
\text { POSRAM }\end{array}$ & 43,77 & 3,52 & 45,72 & 3,27 & $-4,96$ & 28 & $-1,94$ & 2,11 & 0,000 \\
\hline $\begin{array}{l}\text { Dist2MI- } \\
\text { POSRAM }\end{array}$ & 43,91 & 4,20 & 42,77 & 3,65 & 2,60 & 28 & 1,13 & 2,35 & 0,014 \\
\hline \multicolumn{10}{|c|}{ Medidas Angulares } \\
\hline Ang3MSup. & 75,01 & 11,52 & 77,22 & 15,49 & $-1,10$ & 28 & $-2,20$ & 10,76 & 0,279 \\
\hline Ang3MInf. & 59,58 & 16,15 & 54,68 & 13,32 & 2,10 & 28 & 4,89 & 12,49 & 0,043 \\
\hline
\end{tabular}

Tabela 10 - Resultados dos testes t pareados da comparação entre os lados esquerdo e direito do Grupo 2 (oclusão normal).

\begin{tabular}{|c|c|c|c|c|c|c|c|c|c|}
\hline \multirow{3}{*}{ VARIÁVEIS } & \multicolumn{4}{|c|}{ Oclusão Normal - (Grupo 2) } & \multirow{3}{*}{$\begin{array}{c}\text { Valor } \\
\mathrm{t}\end{array}$} & \multirow{3}{*}{ G.L. } & \multirow{3}{*}{ Dif. } & \multirow{3}{*}{$\begin{array}{l}\text { D.P. } \\
\text { Dif. }\end{array}$} & \multirow{3}{*}{$\mathrm{p}$} \\
\hline & \multicolumn{2}{|c|}{ Lado Esquerdo } & \multicolumn{2}{|c|}{ Lado Direito } & & & & & \\
\hline & Média & D.P. & Média & D.P. & & & & & \\
\hline \multicolumn{10}{|c|}{ Medidas Lineares } \\
\hline $\begin{array}{l}\text { Dist2MS- } \\
\text { POSRAM }\end{array}$ & 45,28 & 3,53 & 45,34 & 4,23 & $-0,16$ & 16 & $-0,05$ & 1,49 & 0,873 \\
\hline $\begin{array}{l}\text { Dist2Ml- } \\
\text { POSRAM }\end{array}$ & 46,72 & 3,68 & 46,70 & 4,51 & 0,05 & 16 & 0,01 & 1,34 & 0,957 \\
\hline \multicolumn{10}{|c|}{ Medidas Angulares } \\
\hline Ang3MSup. & 71,44 & 10,32 & 68,82 & 8,81 & 0,95 & 16 & 2,61 & 11,32 & 0,354 \\
\hline Ang3MInf. & 71,02 & 20,72 & 73,05 & 18,26 & $-0,91$ & 16 & $-2,02$ & 9,12 & 0,372 \\
\hline
\end{tabular}

Tabela 11- Resultados do teste $t$ independente da comparação das assimetrias lineares e angulares dos terceiros molares do Grupo 1 (Classe II, subdivisão) com as do Grupo 2 (oclusão normal).

\begin{tabular}{|c|c|c|c|c|c|c|c|}
\hline \multirow{2}{*}{ VARIÁVEIS } & \multicolumn{2}{|c|}{$\begin{array}{c}\text { Classe II, subdivisãc } \\
\text { (Grupo 1) }\end{array}$} & \multicolumn{2}{|c|}{$\begin{array}{c}\text { Oclusão Normal } \\
\text { (Grupo 2) }\end{array}$} & \multirow[t]{2}{*}{ Valor $\mathrm{t}$} & \multirow[t]{2}{*}{ G.L. } & \multirow{2}{*}{$\mathrm{p}$} \\
\hline & Média & D.P. & Média & D.P. & & & \\
\hline \multicolumn{8}{|c|}{ Medidas Lineares } \\
\hline $\begin{array}{l}\text { Dif2MS- } \\
\text { POSRAM }\end{array}$ & 2,29 & 1,71 & 1,00 & 1,08 & 2,78 & 44 & 0,007 \\
\hline $\begin{array}{l}\text { Dif2MI- } \\
\text { POSRAM }\end{array}$ & 2,20 & 1,35 & 0,98 & 0,89 & 3,31 & 44 & 0,001 \\
\hline \multicolumn{8}{|c|}{ Medidas Angulares } \\
\hline DifAng3MSup. & 8,48 & 6,81 & 8,91 & 7,15 & $-0,20$ & 44 & 0,840 \\
\hline DifAng3MInf. & 9,10 & 9,75 & 6,61 & 6,33 & 0,93 & 44 & 0,353 \\
\hline
\end{tabular}


RADIOGRAFIAS PANORÂMICAS

Tabela 12 - Resultados dos testes t pareados da comparação entre os lados de Classe I e Classe II do Grupo 1 (Classe II, subdivisão).

\begin{tabular}{|c|c|c|c|c|c|c|c|c|c|}
\hline \multirow{3}{*}{ VARIÁVEIS } & \multicolumn{4}{|c|}{ Classe II, subdivisão - (Grupo 1) } & \multirow{3}{*}{$\begin{array}{c}\text { Valor } \\
\mathrm{t}\end{array}$} & \multirow{3}{*}{ G.L. } & \multirow{3}{*}{ Dif. } & \multirow{3}{*}{$\begin{array}{l}\text { D.P. } \\
\text { Dif. }\end{array}$} & \multirow{3}{*}{$p$} \\
\hline & \multicolumn{2}{|c|}{ Lado de Classe I } & \multicolumn{2}{|c|}{ Lado de Classe II } & & & & & \\
\hline & Média & D.P. & Média & D.P. & & & & & \\
\hline \multicolumn{10}{|c|}{ Medidas Angulares } \\
\hline Ang3MSup. & 116,82 & 16,46 & 115,54 & 14,37 & 0,53 & 28 & 1,27 & 12,86 & 0,596 \\
\hline Ang3MInf. & 43,46 & 15,51 & 38,01 & 12,04 & 2,50 & 28 & 5,44 & 11,71 & 0,018 \\
\hline
\end{tabular}

Tabela 13 - Resultados dos testes t pareados da comparação entre os lados esquerdo e direito do Grupo 2 (oclusão normal).

\begin{tabular}{|c|c|c|c|c|c|c|c|c|c|}
\hline \multirow{3}{*}{ VARIÁVEIS } & \multicolumn{4}{|c|}{ Oclusão Normal - (Grupo 2) } & \multirow{3}{*}{$\begin{array}{c}\text { Valor } \\
t\end{array}$} & \multirow{3}{*}{ G.L. } & \multirow{3}{*}{ Dif. } & \multirow{3}{*}{$\begin{array}{l}\text { D.P. } \\
\text { Dif. }\end{array}$} & \multirow{3}{*}{$\mathrm{p}$} \\
\hline & \multicolumn{2}{|c|}{ Lado Esquerdo } & \multicolumn{2}{|c|}{ Lado Direito } & & & & & \\
\hline & Média & D.P. & Média & D.P. & & & & & \\
\hline \multicolumn{10}{|c|}{ Medidas Angulares } \\
\hline Ang3MSup. & 116,25 & 10,57 & 117,40 & 10,99 & $-0,45$ & 16 & $-1,14$ & 10,27 & 0,653 \\
\hline Ang3MInf. & 49,19 & 19,00 & 54,55 & 18,09 & $-2,98$ & 16 & $-5,36$ & 7,40 & 0,008 \\
\hline
\end{tabular}

Tabela 14 - Resultados do teste t independente da comparação das assimetrias angulares dos terceiros molares do Grupo 1 (Classe II, subdivisão) com as do Grupo 2 (oclusão normal).

\begin{tabular}{l|c|c|c|c|c|c|c|}
\hline \multirow{2}{*}{ VARIÁVEIS } & \multicolumn{2}{|c|}{$\begin{array}{c}\text { Classe II, subdivisão } \\
\text { (Grupo 1) }\end{array}$} & \multicolumn{2}{|c|}{$\begin{array}{c}\text { Oclusão Normal } \\
\text { (Grupo 2) }\end{array}$} & \multirow{2}{*}{ Valor t } & G.L. & $\mathrm{p}$ \\
\cline { 2 - 5 } & Média & D.P. & Média & D.P. & & \\
\hline \multicolumn{8}{|c|}{ Medidas Angulares } \\
\hline DifSubONSup. & 9,45 & 8,64 & 6,76 & 7,64 & 1,06 & 44 & 0,294 \\
\hline DifSubONInf. & 7,79 & 10,25 & 7,22 & 5,47 & 0,21 & 44 & 0,833 \\
\hline
\end{tabular}




\section{RESULTADOS DOS SUBGRUPOS DE CLASSE II SUBDIVISÃO: TIPOS 1 e 2.}

\section{TIPO 1:}

\section{RADIOGRAFIAS OBLÍQUAS CORRIGIDAS}

Tabela 15 - Resultados dos testes t pareados da comparação entre os lados de Classe I e Classe II do subgrupo Tipo 1 (Classe II, subdivisão - Tipo 1).

\begin{tabular}{|c|c|c|c|c|c|c|c|c|c|}
\hline \multirow[t]{3}{*}{ VARIÁVEIS } & \multicolumn{4}{|c|}{$\begin{array}{c}\text { Classe II, subdivisão } \\
\text { (Subgrupo Tipo 1) }\end{array}$} & \multirow{3}{*}{$\begin{array}{c}\text { Valor } \\
t\end{array}$} & \multirow{3}{*}{ G.L. } & \multirow{3}{*}{ Dif. } & \multirow{3}{*}{$\begin{array}{l}\text { D.P. } \\
\text { Dif. }\end{array}$} & \multirow{3}{*}{$\mathrm{p}$} \\
\hline & \multicolumn{2}{|c|}{ Lado de Classe I } & \multicolumn{2}{|c|}{ Lado de Classe II } & & & & & \\
\hline & Média & D.P. & Média & D.P. & & & & & \\
\hline \multicolumn{10}{|c|}{ Medidas Lineares } \\
\hline $\begin{array}{l}\text { Dist2MS- } \\
\text { POSRAM }\end{array}$ & 43,33 & 3,81 & 45,05 & 3,55 & $-3,90$ & 17 & $-1,72$ & 1,87 & 0,001 \\
\hline $\begin{array}{l}\text { Dist2MI- } \\
\text { POSRAM }\end{array}$ & 43,44 & 4,48 & 41,83 & 3,97 & 3,42 & 17 & 1,61 & 1,99 & 0,003 \\
\hline \multicolumn{10}{|c|}{ Medidas Angulares } \\
\hline Ang3MSup. & 73,63 & 9,52 & 75,19 & 13,49 & $-0,90$ & 17 & $-1,55$ & 7,27 & 0,376 \\
\hline Ang3MInf. & 56,11 & 11,88 & 51,55 & 12,98 & 2,11 & 17 & 4,55 & 9,12 & 0,049 \\
\hline
\end{tabular}

Tabela 16 - Resultados do teste $t$ independente da comparação das assimetrias lineares e angulares dos terceiros molares do subgrupo Tipo 1 (Classe II, subdivisão, Tipo 1) com as do Grupo 2 (oclusão normal).

\begin{tabular}{|c|c|c|c|c|c|c|c|}
\hline \multirow[t]{2}{*}{ VARIÁVEIS } & \multicolumn{2}{|c|}{$\begin{array}{c}\text { Classe II, subdivisão } \\
\text { (Subgrupo Tipo 1) }\end{array}$} & \multicolumn{2}{|c|}{$\begin{array}{c}\text { Oclusão Normal } \\
\text { (Grupo 2) }\end{array}$} & \multirow{2}{*}{ Valor $\mathrm{t}$} & \multirow{2}{*}{ G.L. } & \multirow[t]{2}{*}{$\mathrm{p}$} \\
\hline & Média & D.P. & Média & D.P. & & & \\
\hline \multicolumn{8}{|c|}{ Medidas Lineares } \\
\hline $\begin{array}{l}\text { Dif2MS- } \\
\text { POSRAM }\end{array}$ & 1,94 & 1,62 & 1,00 & 1,08 & 2,00 & 33 & 0,052 \\
\hline $\begin{array}{l}\text { Dif2Ml- } \\
\text { POSRAM }\end{array}$ & 2,27 & 1,11 & 0,98 & 0,89 & 3,78 & 33 & 0,000 \\
\hline \multicolumn{8}{|c|}{ Medidas Angulares } \\
\hline DifAng3MSup. & 5,72 & 4,55 & 8,91 & 7,15 & $-1,58$ & 33 & 0,123 \\
\hline DifAng3MInf. & 7,11 & 7,19 & 6,61 & 6,33 & 0,21 & 33 & 0,831 \\
\hline
\end{tabular}


RADIOGRAFIAS PANORÂMICAS

Tabela 17 - Resultados dos testes t pareados da comparação entre os lados de Classe I e Classe II do subgrupo Tipo 1.

\begin{tabular}{|c|c|c|c|c|c|c|c|c|c|}
\hline \multirow{3}{*}{ VARIÁVEIS } & \multicolumn{4}{|c|}{$\begin{array}{c}\text { Classe II, subdivisão } \\
\text { (Subgrupo Tipo 1) }\end{array}$} & \multirow{3}{*}{$\begin{array}{c}\text { Valor } \\
\mathrm{t}\end{array}$} & \multirow{3}{*}{ G.L. } & \multirow{3}{*}{ Dif. } & \multirow{3}{*}{$\begin{array}{l}\text { D.P. } \\
\text { Dif. }\end{array}$} & \multirow{3}{*}{$p$} \\
\hline & \multicolumn{2}{|c|}{ Lado de Classe I } & \multicolumn{2}{|c|}{ Lado de Classe II } & & & & & \\
\hline & Média & D.P. & Média & D.P. & & & & & \\
\hline \multicolumn{10}{|c|}{ Medidas Angulares } \\
\hline Ang3MSup. & 121,30 & 13,82 & 119,88 & 8,95 & 0,66 & 17 & 1,41 & 9,06 & 0,516 \\
\hline Ang3MInf. & 37,98 & 10,97 & 35,72 & 10,95 & 1,28 & 17 & 2,26 & 7,43 & 0,214 \\
\hline
\end{tabular}

Tabela 18 - Resultados do teste $t$ independente da comparação das assimetrias angulares dos terceiros molares do subgrupo Tipo 1, com as do Grupo 2.

\begin{tabular}{l|c|c|c|c|c|c|c|c}
\hline \multirow{2}{*}{ VARIÁVEIS } & \multicolumn{2}{|c|}{$\begin{array}{c}\text { Classe II, subdivisão } \\
\text { (Subgrupo Tipo 1) }\end{array}$} & \multicolumn{2}{|c|}{$\begin{array}{c}\text { Oclusão Normal } \\
\text { (Grupo 2) }\end{array}$} & \multirow{2}{*}{ Valor t } & \multirow{2}{*}{ G.L. } & p \\
\cline { 2 - 5 } & Média & D.P. & Média & D.P. & & \\
\hline \multicolumn{8}{|c|}{ Medidas Angulares } \\
\hline DifSubONSup. & 6,75 & 6,01 & 6,76 & 7,64 & $-0,00$ & 33 & 0,994 \\
\hline DifSubONInf. & 5,62 & 5,21 & 7,22 & 5,47 & $-0,88$ & 33 & 0,383 \\
\hline
\end{tabular}




\section{TIPO 2:}

\section{RADIOGRAFIAS OBLÍQUAS CORRIGIDAS}

Tabela 19 - Resultados dos testes t pareados da comparação entre os lados de Classe I e Classe II do subgrupo Tipo 2.

\begin{tabular}{|c|c|c|c|c|c|c|c|c|c|}
\hline \multirow{3}{*}{ VARIÁVEIS } & \multicolumn{4}{|c|}{$\begin{array}{c}\text { Classe II, subdivisão } \\
\text { (Subgrupo Tipo 2) }\end{array}$} & \multirow{3}{*}{$\begin{array}{c}\text { Valor } \\
\mathrm{t}\end{array}$} & \multirow{3}{*}{ G.L. } & \multirow{3}{*}{ Dif. } & \multirow{3}{*}{$\begin{array}{l}\text { D.P. } \\
\text { Dif. }\end{array}$} & \multirow{3}{*}{$p$} \\
\hline & \multicolumn{2}{|c|}{ Lado de Classe I } & \multicolumn{2}{|c|}{ Lado de Classe II } & & & & & \\
\hline & Média & D.P. & Média & D.P. & & & & & \\
\hline \multicolumn{10}{|c|}{ Medidas Lineares } \\
\hline $\begin{array}{l}\text { Dist2MS- } \\
\text { POSRAM }\end{array}$ & 45,58 & 3,32 & 47,83 & 2,92 & $-2,33$ & 5 & $-2,25$ & 2,36 & 0,066 \\
\hline $\begin{array}{l}\text { Dist2MI- } \\
\text { POSRAM }\end{array}$ & 46,41 & 4,07 & 45,50 & 2,07 & 0,72 & 5 & 0,91 & 3,10 & 0,502 \\
\hline \multicolumn{10}{|c|}{ Medidas Angulares } \\
\hline Ang3MSup. & 76,83 & 10,34 & 87,50 & 20,20 & $-1,94$ & 5 & $-10,66$ & 13,42 & 0,109 \\
\hline Ang3MInf. & 70,83 & 20,67 & 59,83 & 11,77 & 1,28 & 5 & 11,00 & 20,94 & 0,254 \\
\hline
\end{tabular}

Tabela 20 - Resultados do teste $t$ independente da comparação das assimetrias lineares e angulares dos terceiros molares do subgrupo Tipo 2, com as do Grupo 2.

\begin{tabular}{|c|c|c|c|c|c|c|c|}
\hline \multirow[t]{2}{*}{ VARIÁVEIS } & \multicolumn{2}{|c|}{$\begin{array}{c}\text { Classe II, subdivisão } \\
\text { (Subgrupo Tipo 2) }\end{array}$} & \multicolumn{2}{|c|}{$\begin{array}{c}\text { Oclusão Normal } \\
\text { (Grupo 2) }\end{array}$} & \multirow[t]{2}{*}{ Valor $\mathrm{t}$} & \multirow[t]{2}{*}{ G.L. } & \multirow[t]{2}{*}{$\mathrm{p}$} \\
\hline & Média & D.P. & Média & D.P. & & & \\
\hline \multicolumn{8}{|c|}{ Medidas Lineares } \\
\hline $\begin{array}{l}\text { Dif2MS- } \\
\text { POSRAM }\end{array}$ & 2,58 & 1,90 & 1,00 & 1,08 & 2,50 & 21 & 0,020 \\
\hline $\begin{array}{l}\text { Dif2Ml- } \\
\text { POSRAM }\end{array}$ & 2,25 & 2,13 & 0,98 & 0,89 & 2,05 & 21 & 0,052 \\
\hline \multicolumn{8}{|c|}{ Medidas Angulares } \\
\hline DifAng3MSup. & 14,33 & 8,38 & 8,91 & 7,15 & 1,52 & 21 & 0,141 \\
\hline DifAng3MInf. & 15,66 & 17,01 & 6,61 & 6,33 & 1,91 & 21 & 0,069 \\
\hline
\end{tabular}




\section{RADIOGRAFIAS PANORÂMICAS}

Tabela 21 - Resultados dos testes t pareados da comparação entre os lados de Classe I e Classe II do subgrupo Tipo 2.

\begin{tabular}{|c|c|c|c|c|c|c|c|c|c|}
\hline \multirow{3}{*}{ VARIÁVEIS } & \multicolumn{4}{|c|}{$\begin{array}{l}\text { Classe II, subdivisão } \\
\text { (Subgrupo Tipo 2) }\end{array}$} & \multirow{3}{*}{$\begin{array}{c}\text { Valor } \\
\mathrm{t}\end{array}$} & \multirow{3}{*}{ G.L. } & \multirow{3}{*}{ Dif. } & \multirow{3}{*}{$\begin{array}{l}\text { D.P. } \\
\text { Dif. }\end{array}$} & \multirow{3}{*}{$p$} \\
\hline & \multicolumn{2}{|c|}{ Lado de Classe I } & \multicolumn{2}{|c|}{ Lado de Classe II } & & & & & \\
\hline & Média & D.P. & Média & D.P. & & & & & \\
\hline \multicolumn{10}{|c|}{ Medidas Angulares } \\
\hline Ang3MSup. & 109,93 & 17,85 & 102,50 & 24,18 & 1,03 & 5 & 7,43 & 17,67 & 0,350 \\
\hline Ang3MInf. & 54,13 & 17,10 & 41,15 & 8,11 & 1,52 & 5 & 12,98 & 20,82 & 0,187 \\
\hline
\end{tabular}

Tabela 22 - Resultados do teste $t$ independente da comparação das assimetrias angulares dos terceiros molares do subgrupo Tipo 2, com as do Grupo 2.

\begin{tabular}{l|c|c|c|c|c|c|c}
\hline \multirow{2}{*}{ VARIÁVEIS } & \multicolumn{2}{|c|}{$\begin{array}{c}\text { Classe II, subdivisão } \\
\text { (Subgrupo Tipo 2) }\end{array}$} & \multicolumn{2}{|c|}{$\begin{array}{c}\text { Oclusão Normal } \\
\text { (Grupo 2) }\end{array}$} & \multirow{2}{*}{ Valor t } & \multirow{2}{*}{ G.L. } & \multirow{2}{*}{$p$} \\
\cline { 2 - 5 } & Média & D.P. & Média & D.P. & & & \\
\hline \multicolumn{8}{|c|}{ Medidas Angulares } \\
\hline DifSubONSup. & 15,20 & 10,07 & 6,76 & 7,64 & 2,14 & 21 & 0,043 \\
\hline DifSubONInf. & 13,98 & 20,03 & 7,22 & 5,47 & 1,30 & 21 & 0,204 \\
\hline
\end{tabular}




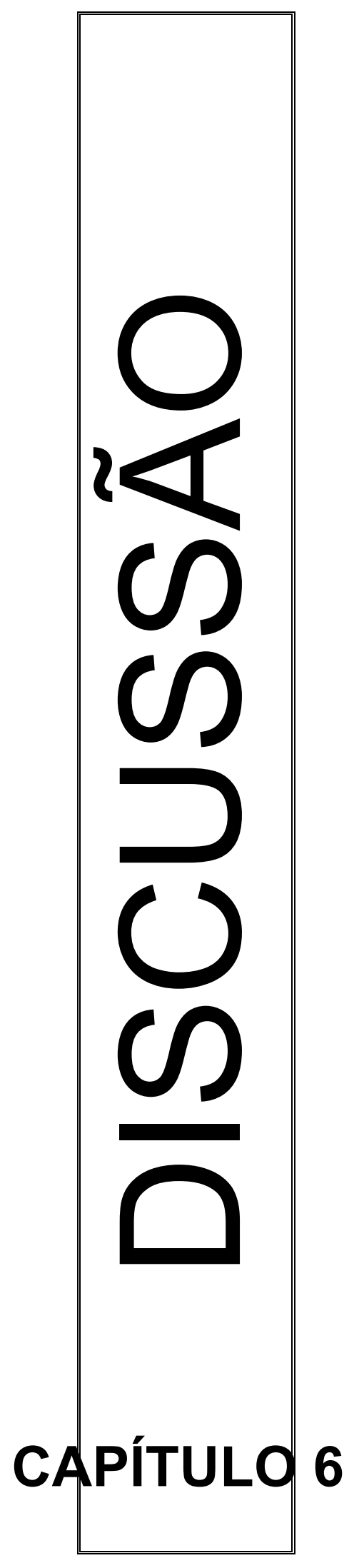




\section{6- DISCUSSÃO}

bjetivando proporcionar o melhor entendimento e interpretação dos resultados obtidos neste trabalho, serão abordados, seqüencialmente, os aspectos concernentes à amostra e metodologia empregadas, à mensuração das grandezas cefalométricas e à precisão da metodologia. Posteriormente, serão discutidos os resultados obtidos nas radiografias oblíquas corrigidas e panorâmicas nos grupos analisados, e finalmente, as implicações clínicas desses resultados.

\subsection{Seleção da Amostra}

Primeiramente, para a complementação da amostra de Classe II, subdivisão inicial já existente na Disciplina de Ortodontia, houve a necessidade de serem realizadas novas triagens. Em torno de 600 pacientes foram examinados e somente 14 obedeceram aos critérios estabelecidos para o grupo de má oclusão de Classe II, subdivisão completa descritos no capítulo de Material e Método. Verificou-se que a maioria das más oclusões de Classe II avaliadas eram bilaterais tornando-se difícil encontrar casos com Classe II unilateral e ainda serem enquadrados dentro dos critérios convencionados para esta pesquisa. Estes pacientes previamente selecionados foram somados aos pacientes já pertencentes ao arquivo do Departamento, perfazendo um total de 44 casos de Classe II, subdivisão. Após o exame das radiografias dos 44 casos selecionados, somente 29 pacientes puderam participar deste estudo uma vez que era necessária a presença dos terceiros molares nos quatro quadrantes.

Aprofundando o estudo, realizou-se a comparação das assimetrias de posição linear e angular dos terceiros molares em relação a um grupo de oclusão normal. Para tanto, avaliou-se o grupo controle de 30 casos de oclusão normal pertencentes ao Departamento de Ortodontia da Faculdade de Odontologia de Bauru-USP, percebendo-se que somente 17 pacientes apresentavam os terceiros molares presentes em todos os quadrantes, com toda a seqüência de radiografias já obtidas para a análise deste estudo. Desta forma, procedeu-se, nas radiografias oblíquas 
corrigidas e panorâmicas, à comparação das assimetrias de posição angular dos terceiros molares, dos lados direito e esquerdo, entre os grupos de Classe II, subdivisão, não tratado (29 casos) e de oclusão normal (17 casos).

Para a realização deste trabalho, ao todo, foram utilizadas 29 radiografias submentonianas, 58 radiografias oblíquas corrigidas e 29 panorâmicas pertencentes ao grupo experimental. Para o grupo controle, foram obtidas 17 submentonianas, 34 oblíquas corrigidas e 17 panorâmicas.

Os critérios para seleção da amostra foram realizados por meio de anamnese, exames clínico e radiográfico. Selecionaram-se dois grupos com características dentárias bem definidas da má oclusão em estudo e de oclusão normal. Em ambos os grupos, todos os pacientes deveriam apresentar todos os dentes permanentes superiores e inferiores, em ambos os arcos dentários $3,65,85,93,145,162$. Eliminou-se assim, a possibilidade de movimentações dentárias que ocasionariam desarranjos no relacionamento dos dentes e influenciariam o aparecimento de assimetrias dentárias ${ }^{65}$. Adotou-se este procedimento, pois já se demonstrou que mutilações nos arcos dentários e ausência de dentes, durante o desenvolvimento mandibular, podem provocar uma assimetria esquelética ${ }^{146}$ e uma remodelação condilar $^{102}$. Além disso, foram incluídos apenas os casos que apresentavam a relação molar de Classe I de um lado e de Classe II completa do outro, pois casos com molar em relação de $1 / 2$ Classe II poderiam atenuar as reais características da Classe II, subdivisão. Estes jovens não deveriam ter sido submetidos ao tratamento ortodôntico, pois assim poderiam mascarar o verdadeiro relacionamento dos dentes com as bases apicais ${ }^{65,93,145}$.

Outro pré-requisito consistiu na ausência de deslocamento mandibular lateral

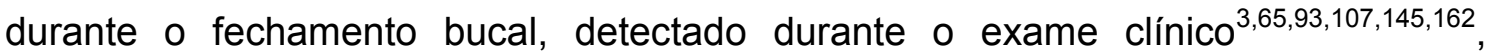
baseado nos trabalhos de WILLIAMSON ${ }^{187}$ e SLAVICEK $^{171}$ que asseguravam que a presença de um deslocamento mandibular lateral devido a algum contato prematuro causa uma alteração da relação ântero-posterior do lado contrário ao desvio, ocasionando um diagnóstico errôneo da oclusão daquele lado. Este critério 
concordou com os pensamentos de SHROFF; SIEGEL ${ }^{167}$ que preconizavam que "as assimetrias resultantes de desvios funcionais mandibulares geralmente decorrem de contatos prematuros em cêntrica, causando um desvio mandibular lateral na máxima intercuspidação habitual”.

Foram descartados também pacientes com histórico de trauma facial ou condições médicas que poderiam ter alterado o crescimento das bases apicais como pré-requisitos para a seleção da amostra ${ }^{65,93,124,145}$, porque já se demonstrou que as respostas compensatórias a uma injúria podem desencadear um desequilíbrio no crescimento compensatório do côndilo e do ramo como um todo ${ }^{123,177}$ e já se comprovou que há uma associação entre o trauma e o crescimento assimétrico mandibular $83,124,167,177$.

Houve a tolerância máxima de três milímetros de apinhamento nos arcos dentários superior e/ou inferior, nos casos de Classe II, subdivisão, desde que simétrico, pois assim não ocasionariam assimetrias dentoalveolares decorrentes de problemas de falta de espaço em um quadrante. Devido à dificuldade em se encontrar más oclusões sem nenhum apinhamento, permitiu-se a presença deste pequeno apinhamento ${ }^{3,65,93}$.

Quanto ao dimorfismo sexual, apesar da pequena falta de proporcionalidade entre os gêneros masculino e feminino nos dois grupos estudados, não se considerou um problema já que ARNOLD; ANDERSON; LILYEMARK ${ }^{9}$, ao estabelecerem padrões de normalidade nas radiografias submentonianas, não verificaram diferenças estatisticamente significantes entre os gêneros, quanto às assimetrias. MELNIK ${ }^{98}$, avaliando as assimetrias por meio de radiografias oblíquas a $45^{\circ}$, também afirmou que após os 14 anos de idade, não havia mais diferenças estatisticamente significantes entre os gêneros. PONYI; SZABÓ; NYILASI ${ }^{120}$, realizando medições diretas em mandíbulas de crânios europeus de séculos passados, também não detectaram diferenças significantes entre os gêneros. Analogamente, SHEATS et al. ${ }^{164}$ pesquisando sobre a prevalência das assimetrias dentária e facial em escolares americanos de ambos os gêneros, não verificaram 
uma associação entre o gênero e a assimetria. Não há diferença entre os gêneros quanto à impacção dos terceiros molares ${ }^{1,30,77,137,155}$. Investigando sobre a mineralização e o movimento de irrupção dos terceiros molares inferiores, GARN; LEWIS; BONNÉ ${ }^{40}$ verificaram que em sua formação, o terceiro molar não evidenciou diferença significante quanto ao gênero com relação à época de irrupção. Pesquisando sobre o desenvolvimento dos terceiros molares, ENGSTRÖM; ENGSTRÖM; SAGNE ${ }^{34}$ concluíram que não há dimorfismo sexual, apesar do desenvolvimento nos meninos ocorrer mais cedo do que nas meninas, não houve diferença estatisticamente significante.

Quanto à faixa etária dos grupos, verificou-se que o grupo de Classe II, subdivisão apresentava uma média de idade de 14,73 anos e o de oclusão normal de 21,73 anos. Considerou-se que esta diferença não interferiria nos resultados porque foram comparados os lados direito e esquerdo de cada paciente e também as diferenças entre os lados, entre os grupos. Portanto, a idade de um lado do paciente seria a mesma do outro lado. Além disso, a faixa etária do grupo experimental apresentou-se favorável para o estudo uma vez que a mineralização das coroas dos terceiros molares se completa por volta dos 14 ou 15 anos, podendo ser facilmente visualizadas ${ }^{56}$. Outros trabalhos ${ }^{54,55,56}$ suportaram a utilização de amostras apresentando terceiros molares com rizogênese incompleta.

\subsection{Metodologia}

Inicialmente, foram obtidas as radiografias submentonianas em máxima intercuspidação habitual de acordo com LAM; SADOWSKY; OMERZA ${ }^{80}$, MONGINI; SCHMID $^{103}$, O'BYRN et al., ${ }^{107}$ SCHMID; MONGINI; FELISIO ${ }^{156}, \mathrm{SHAH}^{\prime} \mathrm{JOSHI}^{162}$. Nas submentonianas, mediu-se o ângulo de incidência dos raios $X$, para a projeção paralela de cada lado do paciente, para posteriormente se obter as radiografias oblíquas corrigidas também realizadas em máxima intercuspidação habitual. Desta forma, calculou-se a rotação necessária do cefalostato, para que o lado de interesse das estruturas ficasse paralelo ao filme. 
De modo contrário, outros autores ${ }^{39,144,187,188,189}$ preconizam a obtenção destas radiografias em relação cêntrica quando se deseja detectar qualquer desvio mandibular funcional que possa interferir na avaliação da assimetria mandibular, em relação à maxila e à base do crânio. Isto se aplica, principalmente, aos casos de Classe II, pois estes geralmente apresentam um maior desvio, para anterior, que aqueles com Classe ${ }^{125}$. Entretanto, neste trabalho, um dos critérios adotados no momento da seleção da amostra consistiu na ausência de desvio funcional mandibular lateral em todos os pacientes ${ }^{3,65,67,93,107,145,162}$. Desta forma, objetivou-se uma maior precisão na correta avaliação da assimetria mandibular, em relação à maxila e à base do crânio. Adotou-se a manipulação bilateral da mandíbula em relação cêntrica para a avaliação de qualquer desvio funcional mandibular ${ }^{32,67,109}$. Desde que os pacientes não apresentassem nenhum sintoma de distúrbios temporomandibulares, considerou-se este tipo de manipulação suficiente para levar os côndilos em relação cêntrica ${ }^{67,147}$.

As técnicas radiográficas que possibilitam uma melhor avaliação das assimetrias craniofaciais são a submentoniana, oblíqua corrigida e pósteroanterior $^{11,12,28,39,42,52,65,86,100}$. TAIT $^{176}$ considerou que as radiografias oblíquas a $45^{\circ}$ oferecem uma maior precisão quanto à angulação dos terceiros molares do que as telerradiografias a $90^{\circ}$. Além disso, METAXAS ${ }^{100}$ pesquisou e comprovou que as radiografias oblíquas corrigidas apresentam alto índice de correlação nas suas mensurações para ambos os lados, sendo precisas para a avaliação das assimetrias entre os lados esquerdo e direito de um paciente, tornando este estudo de grande confiabilidade.

Obtiveram-se radiografias panorâmicas ${ }^{111,112,113}$ uma vez que estas radiografias tornaram-se fundamentais e imprescindíveis como meio auxiliar de diagnóstico em todas as áreas da Odontologia ${ }^{5}$. Neste trabalho, as ortopantomográficas fizeram parte da documentação ortodôntica inicial de todos os casos selecionados da amostra, pois serviram para o planejamento do tratamento do grupo experimental ${ }^{24}$. Foram também úteis para a averiguação da presença dos quatro terceiros molares nos arcos dentários ${ }^{90,110}$. Desta forma, além de servirem 
para avaliação clínica, são também utilizadas antes, durante e após o tratamento ortodôntico para se avaliar o paralelismo radicular e angulação dentária mesiodistal ${ }^{95}$. As radiografias panorâmicas obtidas para os casos de oclusão normal contribuíram para a composição do grupo controle necessário para esta pesquisa, obtendo-se assim parâmetros normais ${ }^{101,175}$ na realização da análise estatística.

Mesmo sendo o método de diagnóstico mais universalmente utilizado na classe odontológica, alguns inconvenientes da técnica já foram citados na literatura ${ }^{5,10,151,194}$ dentre as desvantagens, tem-se a imprecisão dimensional inerente às imagens panorâmicas. A distorção nos filmes panorâmicos resulta nas alterações angulares dos dentes inclinados decorrentes das ampliações combinadas nos sentidos vertical e horizontal ${ }^{10,96}$.

Após a obtenção de todas as radiografias, procedeu-se aos traçados radiográficos e posterior digitalização dos pontos de interesse para este trabalho. Utilizaram-se valores absolutos, como abordado no capítulo de Material e Métodos, eliminando a possibilidade de que os valores de diferença positivos ou negativos se cancelassem no cálculo das médias para cada grupo ${ }^{9}$. Outra razão para tal conduta foi devido ao fato de que pacientes que não apresentam assimetria facial ou dentária evidentes demonstram diferenças esqueléticas de tamanho entre os lados direito e esquerdo da maxila e da mandíbula ${ }^{162}$. Além disso, MELNIK ${ }^{98}$ demonstrou que a mandíbula se apresenta assimétrica em jovens em crescimento, em diferentes idades e LUNDSTRÖM ${ }^{88}$ demonstrou que existe um certo grau de assimetria presente no arco dentário, mesmo em pacientes com oclusão normal. Ainda mais, de acordo com algumas teorias de assimetria direcional, verificaram-se desvios dentários ou esqueléticos, predominantemente para um dos lados. Portanto, se os valores reais fossem utilizados, os grupos poderiam apresentar uma assimetria direcional que influiria nos resultados obtidos, levando a conclusões distorcidas ${ }^{65}$. 


\subsection{Mensuração das Grandezas em Computador}

Recorrendo-se à informática, utilizou-se o computador para a mensuração das grandezas cefalométricas, possibilitando-se trabalhar com um maior número de dados em um menor período de tempo. O programa Dentofacial Planner 7.0, disponível na Disciplina de Ortodontia da Faculdade de Odontologia de Bauru-USP, proporcionou a medição com precisão de $0,1 \mathrm{~mm}$ ou $0,1 \mathrm{grau}$, tendo sido já utilizado em diversos trabalhos, assegurando sua fidedignidade ${ }^{11,21,27,28,65,66,68,86,119}$. Permitiu também a exportação dos resultados obtidos para um programa de estatística, garantindo uma maior precisão na transferência de dados de um programa para outro. Assim, o método manual seria menos prático, não só por ser mais lenta a obtenção dos valores das variáveis, como também haveria uma maior possibilidade de erros durante a digitação dos valores obtidos. Portanto, além de diminuir a possibilidade de erros na fase de mensuração das medidas cefalométricas, a utilização do método computadorizado facilitou a manipulação de um grande número de dados ${ }^{129}$.

\subsubsection{Precisão da Metodologia}

Com a finalidade de avaliar a precisão e a reprodutibilidade da investigadora, os traçados anatômicos, a demarcação e digitação dos pontos foram realizados duas vezes para 15 pacientes, selecionados aleatoriamente da amostra total, como recomendado por HOUSTON ${ }^{61}$. Assim, nesta pesquisa, utilizaram-se 45 radiografias da amostra total, sendo 30 oblíquas corrigidas e 15 panorâmicas.

Os erros casuais, segundo HOUSTON ${ }^{61}$, advêm das dificuldades na identificação dos pontos cefalométricos e também devido à imprecisão nas definições de certos pontos. A situação ideal é aquela em que a média das diferenças iguala-se a zero, para uma determinada medida cefalométrica repetida numa série de cefalogramas duplicados, pois isto indica que os erros casuais ocorrem de modo equilibrado nos dois sentidos, isto é, tanto para mais como para menos. Por outro lado, caso a média das diferenças seja diferente de zero, talvez tenha havido uma tendência no direcionamento dos resultados, de modo consciente ou inconsciente, seja subestimando-os ou superestimando-os, reiteradamente ${ }^{154}$. 
Com relação aos erros casuais $^{61}$, observou-se na tabela 1 que, nas radiografias oblíquas corrigidas, os valores acima de $1 \mathrm{~mm}$ foram referentes às variáveis angulares. Todas estas variáveis relacionaram-se ora com a angulação do longo eixo dos terceiros molares inferiores esquerdo e direito (Ang3MIE e Ang3MID) com o plano mandibular ora com o longo eixo dos terceiros molares superiores esquerdo e direito (Ang3MSE e Ang3MSD) com o plano oclusal. Entretanto, estes erros não afetaram a precisão das medidas realizadas. Desde que haja um equilíbrio entre os valores subestimados e os superestimados, as médias serão pouco afetadas ${ }^{61}$. Nas radiografias panorâmicas (tabela 2), as variáveis angulares apresentaram valores acima de $1 \mathrm{~mm}$ devido à dificuldade de determinação dos longos eixos dos terceiros molares ${ }^{10,44,48}$ que se encontravam em formação. Isto se deve ao fato de que boa parte da amostra apresentava os terceiros molares parcialmente irrompidos. O ideal seria que no mínimo $2 / 3$ de raiz formada estivesse presente $^{149}$ para que houvesse uma maior precisão na aferição dos pontos de referência tanto no maior diâmetro mesiodistal da coroa como na porção radicular, próximo à furca ou ápice dos dentes, quando presentes.

Com relação aos erros sistemáticos ${ }^{13,61,129,195}$, tanto nas radiografias oblíquas corrigidas como nas radiografias panorâmicas não houve diferença estatisticamente significante conforme visualizado nos testes t pareados (tabelas 1 e 2).

\subsection{Distribuição da Normalidade da Amostra}

Os testes de distribuição de normalidade de Kolmogorov-Smirnov (K-S) funcionam como um recurso apropriado utilizado para validar qualquer tratamento estatístico a ser empregado subseqüentemente. Foram aplicados (tabelas 3 a 8) neste trabalho para avaliar se a distribuição dos grupos era normal ${ }^{195}$. Verificou-se que somente uma variável (DifAng3MSup., tabela 5) pertencente ao grupo experimental apresentou significância estatística $(p<0,05)$. Entretanto, diante do grande número de casos avaliados neste grupo $(n=29)$, pôde-se prosseguir com a aplicação dos testes $\mathrm{t}^{195}$. 


\subsection{Discussão dos Resultados}

\subsubsection{Espaço para irrupção e angulação dos terceiros molares na Classe II subdivisão}

\subsubsection{Avaliação linear}

Observou-se que a variável referente à distância linear dos segundos molares superiores ao ponto POSRAM (Dist2MS-POSRAM, Grupo 1, tabela 9) apresentou diferença estatisticamente significante entre os lados de Classe I e II, na má oclusão de Classe II, subdivisão. Verificou-se que a média apresentou valor aumentado, definindo-se que o espaço destinado à irrupção do terceiro molar superior apresentouse maior no lado da Classe II. Isto permite concluir que estes dentes apresentam maior probabilidade de irrupção em função do posicionamento mais mesial do segundo molar superior deste lado. Portanto, pode-se relacionar este fato com a segunda etiologia mais freqüente de aparecimento da Classe II, subdivisão que consiste no posicionamento mais mesial do molar superior do lado da Classe $\|^{3,65,145}$. Os resultados entre os lados do grupo de oclusão normal para as variáveis lineares dos molares superiores (Grupo 2, tabela 10) não apresentaram diferença significante. $\mathrm{Na}$ análise da assimetria linear entre os grupos (tabela 11), verificou-se que houve diferença estatisticamente significante para as variáveis dos molares superiores, corroborando com os resultados anteriormente obtidos na análise do grupo de Classe

II, subdivisão (Grupo 1, tabela 9, Gráfico 1). Novamente, poderia se questionar a influência da diferença de idades entre os grupos. Entretanto, verificou-se que apesar da média de idade $(14,73)$ do Grupo 1 ser menor do que a do Grupo $2(21,73)$, houve uma maior assimetria linear para o grupo de Classe II, subdivisão em relação ao grupo controle. Portanto, se essas diferenças se manifestaram mesmo quando o grupo experimental era mais jovem que o controle, elas seriam ainda mais evidentes se as idades fossem compatíveis. Para as variáveis angulares a diferença de idades não interferiria nos resultados.

Para a variável linear do molar inferior Dist2MI-POSRAM (Grupo 1, tabela 9) constatou-se valor menor da média do lado da Classe II em relação ao lado da Classe I. Considerou-se que no lado da Classe II, na mandíbula, ocorreu uma maior tendência de impacção do terceiro molar inferior do que no lado da Classe I em 
virtude de um menor espaço destinado à irrupção do terceiro molar inferior deste lado. Contrastante com esses resultados no grupo de má oclusão, os resultados das variáveis lineares para os molares inferiores, da comparação entre os lados esquerdo e direito do grupo controle (Grupo 2, tabela 10) não apresentaram diferença estatisticamente significante. Isto pode ser facilmente justificável uma vez que em pacientes com oclusão normal há, em ambos os lados, uma certa simetria dentária e esquelética levando às semelhanças das médias dos valores obtidos. Os resultados do teste $t$ independente das assimetrias lineares para os molares inferiores (tabela 11, Gráfico 1) entre o grupo de Classe II, subdivisão e o de oclusão normal foram estatisticamente significantes, corroborando com a comparação intragrupo entre os lados (Grupo 1, tabela 9).

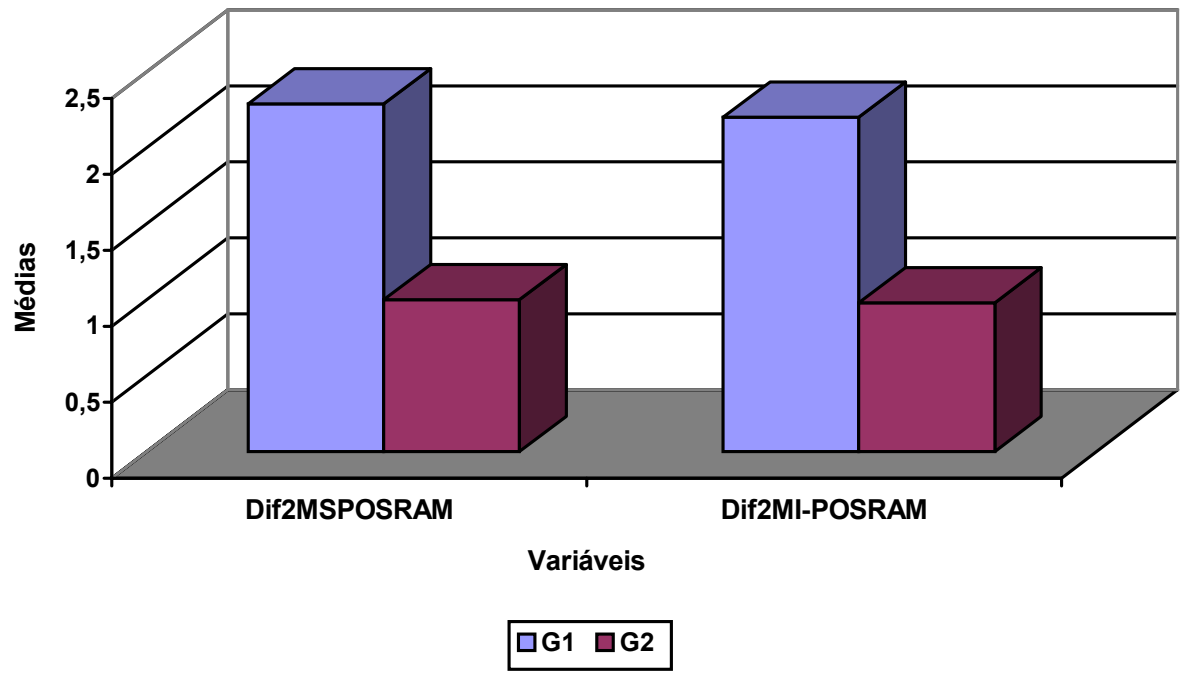

Gráfico 1 - Médias das assimetrias lineares obtidas pelo teste $t$ independente para a análise intergrupos, nas radiografias oblíquas corrigidas, entre os lados de Classe I e Classe II do grupo de Classe II, subdivisão (Grupo 1 = G1) com os lados esquerdo e direito do grupo de oclusão normal (Grupo 2 = G2).

\subsubsection{Avaliação angular}

$\mathrm{Na}$ análise das radiografias oblíquas corrigidas e panorâmicas, a variável angular dos terceiros molares superiores (Ang3MSup., tabelas 9 e 12) não apresentou diferenças estatisticamente significantes, entre os lados de Classe I e Classe II. 
Entretanto, houve uma tendência destas médias para as variáveis dos molares superiores, nas radiografias oblíquas corrigidas, serem maiores do lado da Classe II do que os valores das médias do lado da Classe I, embora não tenha havido significância estatística (tabela 9). Da mesma forma, nas panorâmicas, houve uma tendência de diminuição das médias para o lado da Classe II, apresentando valores angulares menores para os terceiros molares superiores deste lado (tabela 12). Portanto, para ambos os métodos radiográficos, confirmou-se que o posicionamento dos molares superiores apresentou uma maior tendência à irrupção do lado da Classe II, devido às suas angulações mais favoráveis. Isto pode ser explicado mais uma vez em virtude do posicionamento mais mesial do primeiro molar superior do lado da Classe $\|^{3,65,145}$ permitir uma melhor verticalização do terceiro molar superior deste lado.

Os resultados obtidos entre os lados do grupo de oclusão normal não apresentaram diferenças estatisticamente significantes para as variáveis angulares dos molares superiores tanto nas radiografias oblíquas corrigidas como nas panorâmicas (tabelas 10 e 13). Pela análise comparativa das assimetrias angulares entre os grupos, para os molares superiores (tabelas 11 e 14) verificou-se que não houve diferença estatisticamente significante tanto nas radiografias oblíquas corrigidas como nas ortopantomográficas. Observou-se que os valores das assimetrias destas variáveis superiores (DifAng3MSup, tabela 11) foram suavemente menores para as radiografias oblíquas ao se comparar com o grupo 2, de oclusão normal (tabela 11, Gráfico 2). Isto demonstra a grande variabilidade na angulação desses dentes, entre os lados, mesmo em casos de oclusão normal. Entretanto, os resultados nas radiografias panorâmicas, mostraram uma tendência das médias das assimetrias apresentarem valores maiores para o grupo 1 (Classe II, subdivisão) em virtude da menor angulação dos terceiros molares superiores do lado da Classe II permitir uma inclinação mais favorável para irrupção deste lado, mostrando assim maiores diferenças (DifSubONSup., tabela 14, Gráfico 2).

Ao ser avaliada a variável angular dos molares inferiores (Ang3Mlnf., tabelas 9 e 12), nas radiografias oblíquas corrigidas e panorâmicas, verificou-se que houve 
diferença estatisticamente significante entre os lados do grupo 1 (Classe II subdivisão - tabelas 9 e 12). Os longos eixos dos terceiros molares inferiores do lado da Classe II apresentaram uma maior inclinação para mesial em relação ao lado da Classe I. Deste modo, estes dados definiram que as angulações dos terceiros molares inferiores do lado da Classe II apresentaram-se diminuídas em virtude do menor espaço destinado às suas erupções. Isto suporta resultados prévios $3,11,28,65,66,69,86,145$ de que o principal fator etiológico do aparecimento da Classe II, subdivisão (posição mais para distal do molar inferior do lado da Classe II) constituiu-se como fator predisponente para que a maior impacção dos terceiros molares ocorresse no lado da Classe II (tabelas 9 e 12).

Na avaliação intragrupo de oclusão normal não houve diferença significante nas radiografias oblíquas corrigidas, confirmando resultados prévios ${ }^{56}$ (tabela 10). Entretanto, houve diferença estatisticamente significante para a medida angular dos terceiros molares inferiores nas radiografias panorâmicas (Ang3Mlnf. - tabela 13). Este resultado não era esperado uma vez que pacientes com oclusão normal geralmente apresentam angulações semelhantes dos terceiros molares superiores e inferiores dos dois $\operatorname{lados}^{56}$. Além disso, as radiografias panorâmicas apresentam distorções angulares, principalmente na análise dos dentes posteriores, já que estas unidades dentárias são mais sujeitas às variações do padrão da imagem, em função do próprio funcionamento do aparelho, sendo radiografias de menor acuidade para a realização das avaliações angulares ${ }^{10,44,48}$. Além da distorção, inerente à técnica, fatores externos podem afetar o resultado final da radiografia, tais como: assimetria dos arcos dentários, posicionamento incorreto do paciente no aparelho de raios $\mathrm{x}$ panorâmico e a falta de cooperação do paciente durante a execução da técnica ${ }^{151,194}$. Apesar das panorâmicas ocasionarem um considerável grau de distorção na posição dos terceiros molares, não se invalida o uso da radiografia panorâmica já que se constitui no principal meio de diagnóstico ${ }^{45,95}$ e planejamento cirúrgico dos terceiros molares inferiores não irrompidos.

Quando se realizou a comparação das assimetrias angulares das variáveis inferiores entre os grupos, verificou-se que não houve diferença estatisticamente 
significante tanto nas radiografias oblíquas corrigidas como nas ortopantomográficas (tabelas 11 e 14, Gráfico 2). Verificou-se que os valores destas assimetrias apresentaram uma tendência, ora acentuadamente maior, para radiografias oblíquas corrigidas ora suavemente maior, nas radiografias panorâmicas (tabelas 11 e 14). Isto pode ser justificado pela etiologia da Classe II, subdivisão decorrente do posicionamento mais distal do molar inferior do lado da Classe $\|^{3,11,28,65,69,86,145}$ induzir a estas assimetrias maiores para este lado.

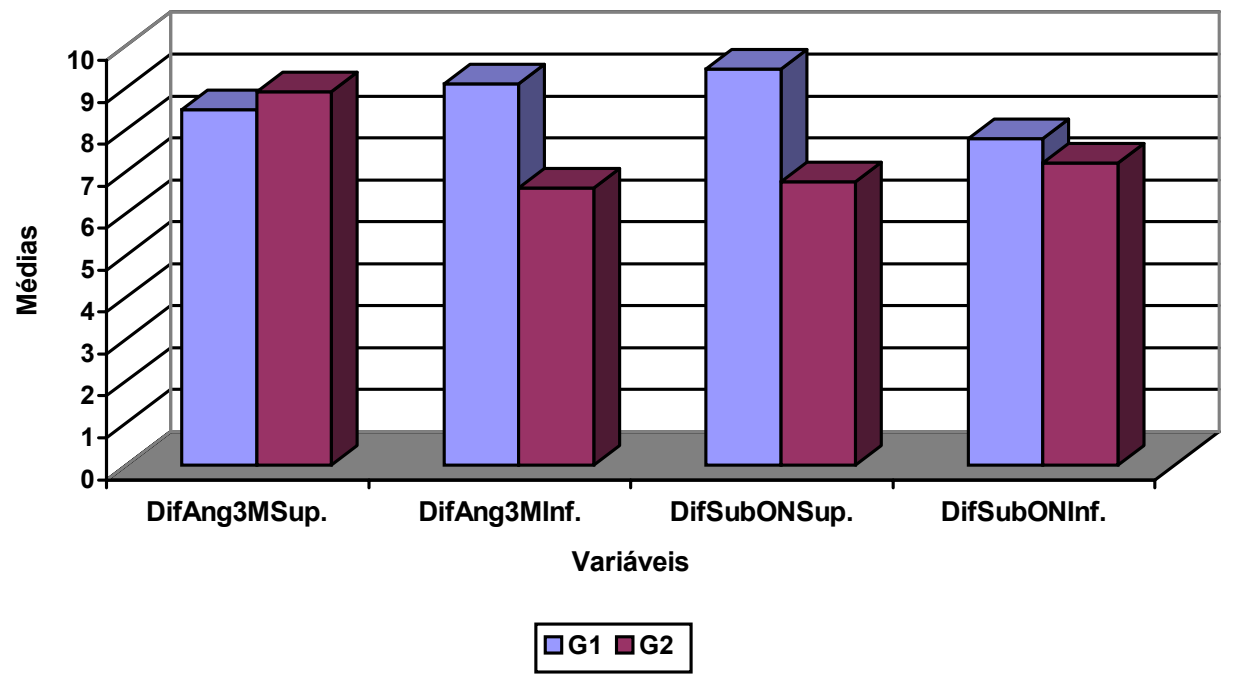

Gráfico 2 - Médias das assimetrias angulares nas radiografias oblíquas corrigidas e panorâmicas obtidas pelos testes independentes da análise intergrupos, entre os lados de Classe I e Classe II, do grupo de Classe II, subdivisão (Grupo 1 = G1) com os lados esquerdo e direito do grupo de oclusão normal (Grupo 2 = G2).

\subsubsection{Espaço para irrupção e angulação dos terceiros molares na Classe II subdivisão (Tipos 1 e 2)}

Considerando a distribuição dos tipos de Classe II, subdivisão, verificou-se que, de acordo com as pesquisas já realizadas ${ }^{3,65,66,70,71,93,145}$, a Classe II, subdivisão ocorre principalmente devido a um posicionamento mais distal do molar inferior, do lado da Classe II e, secundariamente, a um posicionamento mais para mesial do molar superior, deste mesmo lado. Desta forma, como na amostra estudada havia casos apresentando estas duas etiologias, foram selecionados os pacientes por meio da avaliação de fotografias extrabucais frontais ${ }^{11,86}$ ora quando apresentavam a 
Classe II, subdivisão devido ao posicionamento mais para distal do molar inferior (Classe II subdivisão, Tipo 1) ora pelo posicionamento mais mesial do molar superior (Classe II subdivisão, Tipo 2). Não foi objetivada a realização de nova aferição da classificação para se manter a padronização da seleção já obtida e para não se criar subjetividade entre os resultados avaliados, caso houvesse uma segunda classificação. Além disso, a classificação utilizada neste trabalho foi elaborada por duas examinadoras calibradas em pesquisas prévias ${ }^{11,86}$. Assim, foram classificados 18 casos pertencentes ao Tipo 1 e seis casos pertencentes ao Tipo 2. Os demais casos pertenceram ao grupo de pacientes que apresentavam uma combinação de características desses dois tipos, não sendo utilizados na avaliação individualizada dos subgrupos. Desta forma, em relação à quantidade de pacientes em cada subgrupo, houve uma falta de proporcionalidade da amostra. Inicialmente, o grupo de Classe II, subdivisão, apresentava 44 pacientes, entretanto eliminaram-se 15 pacientes, pois no exame detalhado da amostra somente 29 apresentavam os terceiros molares presentes em todos os quadrantes para a realização do estudo. Assim, considerando que o grupo com oclusão normal apresentava 17 jovens; o subgrupo com má oclusão de Classe II, subdivisão, Tipo 1, apresentava 18 pacientes e o subgrupo com má oclusão de Classe II, subdivisão, Tipo 2, apresentava apenas seis pacientes. O maior número de casos de Classe II, subdivisão Tipo 1 corroborou com os registros na literatura de que a Classe II, subdivisão se deve, principalmente, à posição mais para distal do molar inferior, no lado da Classe $\|^{3,65} \mathrm{e}$, secundariamente, devido à posição mais para mesial do molar superior, no lado da Classe $\|^{65}$. Seria ideal se os subgrupos de Classe II, subdivisão estivessem com proporções mais homogêneas. Certamente, haveria uma maior precisão e facilidade de interpretação dos resultados deste estudo se houvesse uma maior participação de casos de acordo com as diferentes etiologias. Entretanto, amostras com grupos experimentais compostos por um grande número de pacientes dificilmente podem ser encontradas $^{33,139}$. Os resultados obtidos com o Tipo 2 neste trabalho constituíram-se apenas de um estudo piloto que deverá ser melhor investigado posteriormente. 


\subsubsection{Espaço para irrupção e angulação dos terceiros molares na Classe II subdivisão (Subgrupo Tipo 1)}

\subsection{Avaliação linear}

Novamente, verificaram-se resultados similares aos encontrados inicialmente na tabela 9, quando todos os casos do grupo 1 (29 casos) tiveram os lados comparados entre si. Houve diferença estatisticamente significante para a variável linear dos molares superiores (Dist2MS-POSRAM, tabela 15). Desta maneira, o espaço destinado à irrupção dos terceiros molares superiores apresentou-se aumentado em relação ao lado da Classe I (Dist2MS-POSRAM), explicitando mais uma vez que mesmo nos casos cuja etiologia principal era o posicionamento mais distal do molar inferior, verificou-se que havia a presença de uma suave participação, embora secundária, do posicionamento mais mesial do molar superior, concordando com trabalhos anteriores $3,65,145$. Na análise das assimetrias lineares dos molares superiores intergrupos (tabela 16, Gráfico 3), verificou-se que não houve diferença estatisticamente significante. Entretanto, houve uma tendência dos molares superiores apresentarem assimetrias maiores para o subgrupo Tipo 1, corroborando com a etiologia secundária do aparecimento da Classe II, subdivisão $3,65,145$.

Houve significância estatística para a variável referente aos molares inferiores (Dist2MI-POSRAM, tabela 15), na análise intragrupo. Verificou-se que o espaço destinado à irrupção dos terceiros molares inferiores apresentou-se diminuído em relação ao lado da Classe I em virtude do principal fator etiológico que ocasiona o aparecimento da Classe II, subdivisão, 31,28,65,69,86,93,145. Na análise comparativa entre os grupos (tabela 16, Gráfico 3) pelos testes t, verificou-se que houve diferença estatisticamente significante para a variável linear dos molares inferiores para o subgrupo Tipo 1. Assim, estes testes detectaram assimetrias lineares significantes nestes 18 casos (Dif2MI-POSRAM, tabela 16, Gráfico 3), pois havia menor espaço destinado aos terceiros molares inferiores do lado da subdivisão já que o posicionamento dos molares inferiores estava mais para distal do lado da Classe $\|^{3,65,145}$. 


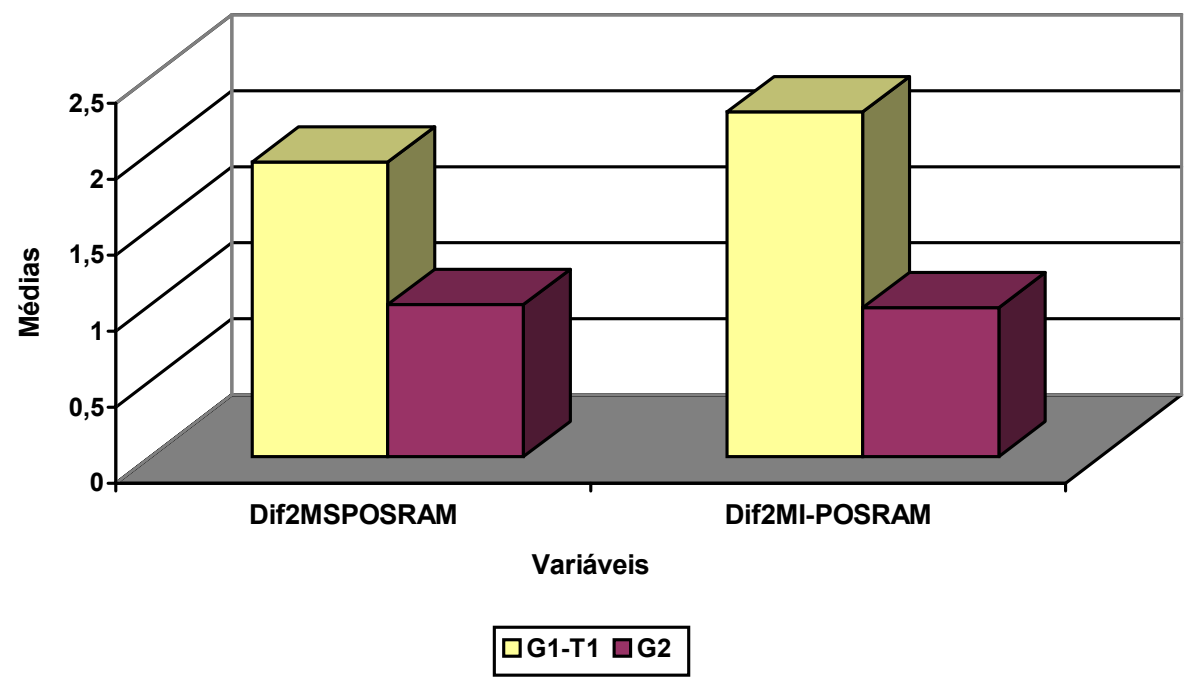

Gráfico 3 - Médias das assimetrias lineares, nas radiografias oblíquas corrigidas, obtidas pelo teste $t$ independente, entre os lados de Classe I e Classe II do subgrupo Tipo 1 (G1-T1) com os lados esquerdo e direito do grupo de oclusão normal (G2).

\subsubsection{Avaliação angular}

Quanto às variáveis angulares dos molares superiores no subgrupo Tipo 1 , nas radiografias oblíquas corrigidas (Ang3MSup., tabela 15), houve uma tendência dos valores das médias serem maiores do lado da Classe II em relação ao lado da Classe I, embora sem apresentar diferença significante. Isto reforça o papel secundário do posicionamento mais mesial do molar superior estar presente ${ }^{3,65,145}$, permitindo que os terceiros molares superiores tenham uma melhor angulação para irrupção (tabela 15). De maneira análoga, nas radiografias panorâmicas, verificou-se uma tendência dos ângulos (Ang3MSup.) dos terceiros molares superiores apresentaram uma diminuição dos seus valores o que reflete numa melhor inclinação dos terceiros molares para irrupção quando se verifica a relação dos seus longos eixos com a linha interorbitária (tabela 17). Os resultados entre os grupos (tabela 16, Gráfico 4) para as diferenças das assimetrias angulares dos terceiros molares superiores não foram estatisticamente significantes. Os resultados das assimetrias angulares dos molares superiores, nas radiografias panorâmicas (tabela 18, Gráfico 4), apresentaram-se diminuídos, embora não significantemente, em relação ao grupo de oclusão normal, 
em consonância com os resultados discutidos na tabela 16, para as assimetrias angulares dos molares superiores.

Nas radiografias oblíquas corrigidas, quando se analisou os resultados das comparações entre os lados do subgrupo Tipo 1 verificou-se significância estatística para a variável angular do terceiro molar inferior (Ang3MInf., tabela 15, Gráfico 4), em consonância com os resultados gerais do grupo 1 (tabela 9). Isto demonstrou que houve uma maior inclinação para mesial do molar inferior no lado da Classe II devido às suas médias serem menores que o lado da Classe I, o que demonstrou uma maior probabilidade de impacção dos terceiros molares inferiores deste lado. Similarmente, nas radiografias panorâmicas (tabela 17), verificou-se resultados que corroboram com os obtidos nas radiografias oblíquas corrigidas (tabela 15). Embora as variáveis angulares não tenham apresentado significância estatística, verificou-se que houve uma tendência das médias das angulações dos terceiros molares inferiores serem menores do lado da Classe II, concordando com o posicionamento mais distal do molar inferior ${ }^{3,65,145}$ se relacionar com a maior tendência de impacção dos terceiros molares deste mesmo lado.

Na comparação das assimetrias angulares intergrupos, verificou-se a ausência de diferenças significantes em ambos os métodos radiográficos avaliados (tabelas 16 e 18, Gráfico 4). Isso demonstra que a assimetria linear entre esses grupos é mais evidente que a assimetria angular, sendo esta última mais variável. 


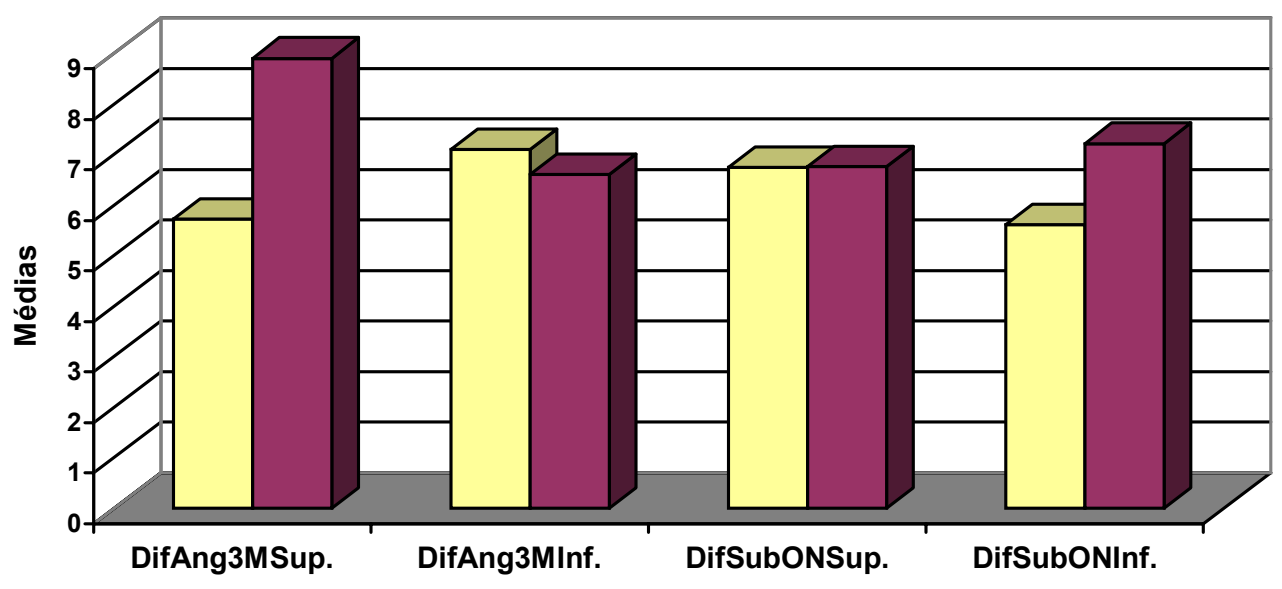

Variáveis

口G1-T1 $\square \mathrm{G} 2$

Gráfico 4 - Médias das assimetrias angulares obtidas pelos testes $t$ independentes, nas oblíquas corrigidas e panorâmicas, entre os lados de Classe I e Classe II, do subgrupo Tipo 1 (G1-T1) com os lados esquerdo e direito do grupo de oclusão normal (G2).

\subsubsection{Espaço para irrupção e angulação dos terceiros molares na Classe} II subdivisão, Tipo 2 (Subgrupo Tipo 2)

\subsubsection{Avaliação linear}

Ao serem analisados os resultados da comparação entre os lados de Classe I e Classe II do subgrupo Tipo 2 (tabela 19), nas radiografias oblíquas corrigidas, não foram constatadas diferenças estatisticamente significantes. Apesar disso, os espaços disponíveis para irrupção dos terceiros molares superiores do lado da Classe II se apresentaram maiores e, portanto, mais favoráveis à irrupção. Para o arco superior, esta tendência mais marcante pode ser atribuída ao posicionamento do molar superior mais mesial do lado da Classe II uma vez que este subgrupo era composto de seis casos selecionados a partir do segundo fator etiológico mais freqüente no aparecimento da Classe II, subdivisão ${ }^{3,65,145}$. Entretanto, os resultados das assimetrias lineares para os molares superiores quando comparados o subgrupo Tipo 2 com o grupo de oclusão normal (Dif2MS-POSRAM, tabela 20, Gráfico 5), nas radiografias oblíquas corrigidas, apresentaram diferença estatisticamente significante. 
Isto confirma a participação do fator etiológico secundário ao aparecimento da Classe II, subdivisão ${ }^{3,65,145}$ estar presente nestes seis casos de subdivisão decorrentes do posicionamento mais mesial do molar superior do lado da Classe II.

Para a análise intragrupo da variável do molar inferior (Dist2MI-POSRAM, tabela 19), não houve diferença estatisticamente significante. Houve uma tendência dos terceiros molares inferiores apresentarem do lado da Classe II um menor espaço retromolar, sendo, portanto, menos favoráveis à irrupção ${ }^{3,65,145}$. Na comparação intergrupos para as assimetrias lineares dos molares inferiores (Dif2MI-POSRAM, tabela 20, Gráfico 5) não se observou diferença estatisticamente significante. Houve uma tendência dos valores das assimetrias lineares dos molares inferiores serem maiores no subgrupo Tipo 2 em relação ao grupo de oclusão normal. Mais uma vez, isto pode ser justificado em virtude, obviamente do menor espaço destinado à irrupção dos terceiros molares inferiores do lado da Classe II, mesmo nesse subgrupo cuja etiologia principal se devia à posição mais mesializada do primeiro molar superior, no lado da Classe II.

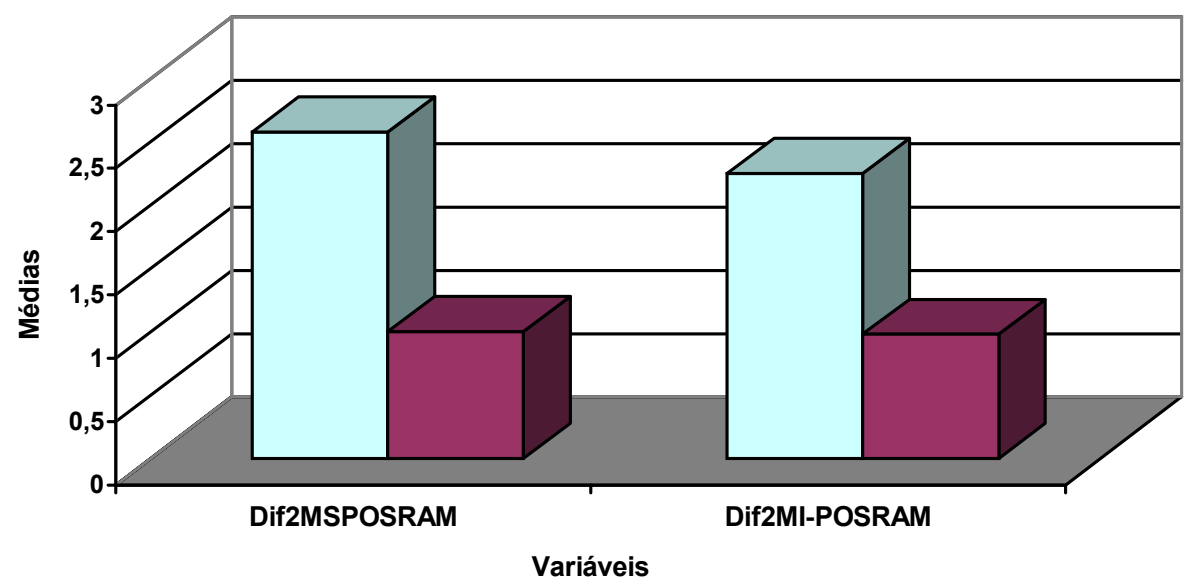

口G1-T2 $\square \mathrm{G} 2$

Gráfico 5 - Médias das assimetrias lineares nas radiografias oblíquas corrigidas, obtidas pelos testes $t$ independente, entre os lados de Classe I e Classe II do subgrupo Tipo 2 (G1-T2) com os lados esquerdo e direito do grupo de oclusão normal (G2). 


\subsubsection{Avaliação angular}

Não houve diferença estatisticamente significante para as variáveis angulares dos molares superiores na análise entre os lados do subgrupo Tipo 2 (tabela 19), nas radiografias oblíquas corrigidas, bem como na comparação intragrupo nas panorâmicas (tabela 21). Houve uma tendência das angulações dos terceiros molares superiores se apresentarem maiores para o lado da Classe II, permitindo uma inclinação mais favorável para irrupção dos terceiros molares superiores deste lado (Ang3MSup., tabela 19). Analogamente, verificou-se menor angulação dos molares superiores nas panorâmicas, representando assim inclinações destes dentes mais favoráveis para irrupção no lado da Classe II (Ang3MSup., tabela 21). Quanto à comparação das assimetrias angulares dos molares superiores entre os grupos, verificou-se que não houve diferenças estatisticamente significantes nas radiografias oblíquas corrigidas (tabela 20, Gráfico 6). Ocorreu uma tendência das assimetrias angulares dos molares superiores serem maiores para o lado da Classe II do subgrupo Tipo 2. Os resultados nas panorâmicas apresentaram diferença estatisticamente significante para a variável angular dos molares superiores (DifSubONSup, tabela 22 e Gráfico 6), demonstrando que quando o primeiro molar superior se encontra mais para mesial, a angulação do terceiro molar é mais favorável à sua irrupção. Apesar da pequena proporção de casos deste subgrupo (seis pacientes), houve a manifestação significante do posicionamento mais mesial do primeiro molar superior do lado da Classe $\|^{3,65,145}$.

Quanto às variáveis angulares dos molares inferiores, ao serem analisadas pela comparação entre os lados do subgrupo Tipo 2, nas radiografias oblíquas e panorâmicas não houve diferença estatisticamente significante (DifAng3MInf., tabelas 19 e 21). Entretanto, houve uma tendência dos ângulos serem menores do lado da Classe II em relação ao lado da Classe I em ambos os métodos. Isto contribui para a maior tendência de impacção dos terceiros molares do lado da Classe II. Na análise comparativa das assimetrias angulares dos molares inferiores, verificou-se que em ambas as radiografias (DifAng3MInf., tabelas 20 e 22, Gráfico 6), não houve diferenças significantes, apesar de haver maiores assimetrias angulares do lado da Classe II. Isto confirma que mesmo nestes seis casos serem decorrentes do 
posicionamento mais mesial do molar superior do lado da Classe II, há ainda a presença combinada do fator etiológico principal que se refere ao posicionamento dos molares inferiores mais para distal do lado da Classe $\|^{3,65,145}$.

Portanto, os resultados demonstraram que as distâncias lineares e as angulações dos terceiros molares superiores e inferiores sofrem influência dos fatores etiológicos determinantes do aparecimento da Classe II, subdivisão. Primeiramente, ora em função do posicionamento mais distal do molar inferior do lado da Classe $\|^{3,65,145}$, ora secundariamente pelo posicionamento mais mesial do molar superior também deste lado ${ }^{65}$.

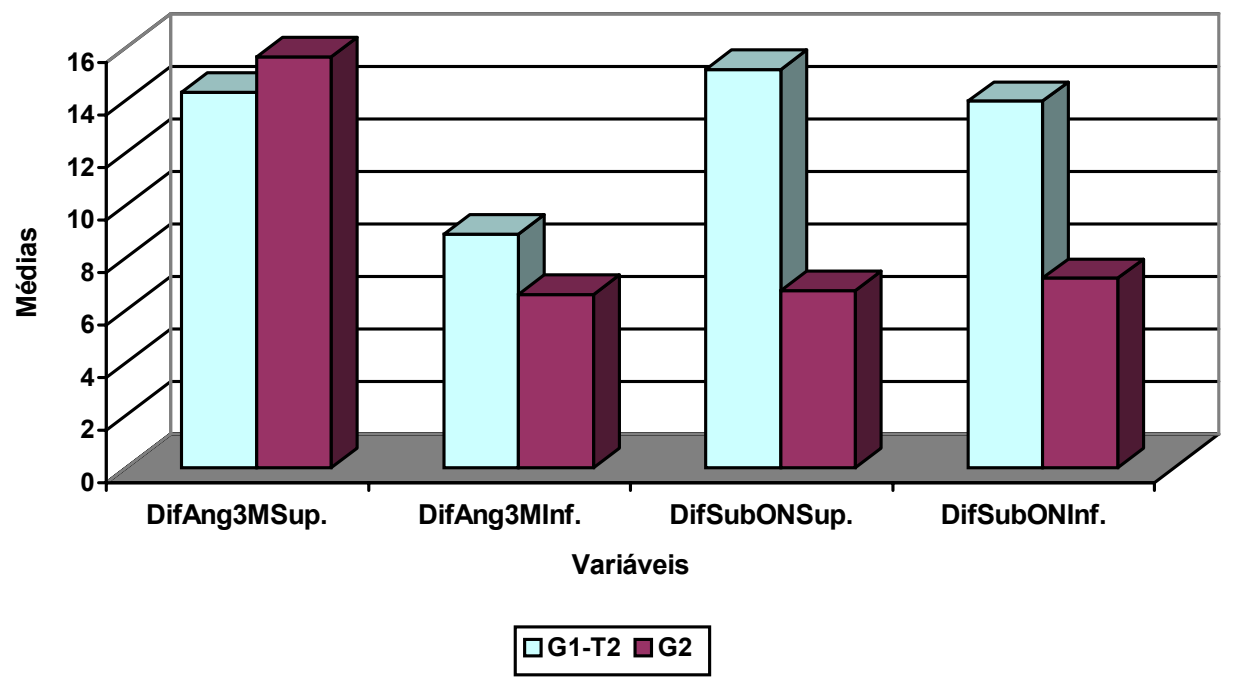

Gráfico 6 - Médias das assimetrias angulares obtidas pelos testes $t$ independentes, nas radiografias oblíquas corrigidas e panorâmicas, entre os lados de Classe I e Classe II, do subgrupo Tipo 2 (G1-T2) com os lados esquerdo e direito do grupo de oclusão normal (G2).

\subsection{Implicações Clínicas}

A presença ou ausência dos terceiros molares, a idade que se desenvolvem, o tempo de irrupção, posição e direção de irrupção são extremamente relevantes para qualquer especialidade da Odontologia ${ }^{56}$. A prevalência de impacção parece ser maior para os terceiros molares do que para qualquer outra unidade dentária ${ }^{30}$, contabilizando $98 \%$ de todos os dentes impactados ${ }^{4}$. HELLMAN ${ }^{58}$ examinando 433 estudantes encontrou uma incidência de 15,2\%, enquanto DACHI; HOWELL ${ }^{30}$ examinando 3.874 pacientes encontraram que $29,9 \%$ dos molares superiores e 
$17,5 \%$ dos molares inferiores apresentavam-se não irrompidos. KRAMER; WILLIAMS $^{77}$ encontraram que a população melanoderma apresentava uma incidência de impacção de 18,2\%, verificando também que os molares superiores são mais freqüentemente não irrompidos que os inferiores. Trabalhos realizados na Escandinávia revelaram que a proporção de impacção dos terceiros molares varia de 19 a 35\% ${ }^{1,20,155}$. Verificou-se que a impacção dos terceiros molares ocorre geralmente devido ao inadequado espaço retromolar ${ }^{4,20,169}$. Se a reabsorção por remodelação da borda anterior da mandíbula ${ }^{4,20,169}$ for limitada, a irrupção dos terceiros molares inferiores pode ficar restringida. Similarmente, a falta de aposição periosteal compensatória do limite posterior da tuberosidade da maxila pode impedir a irrupção dos terceiros molares superiores. O espaço para irrupção dos terceiros molares pode estar também afetado pela direção de irrupção destes dentes durante o desenvolvimento da dentição ${ }^{76}$.

Alguns pesquisadores encontraram que a terapia não extracionista se associa ao aumento significante na freqüência de impacção dos terceiros molares ${ }^{75,134,140,142}$ e à significante redução na freqüência de irrupção destes dentes ${ }^{33,36}$, enquanto que outros $^{49}$ encontraram somente pequenas diferenças entre as amostras tratadas com e sem extrações. Consiste num fato de rotina encontrar terceiros molares não irrompidos mesmo em pacientes tratados ortodonticamente com extrações de prémolares. Entretanto, a incidência de impacção de terceiros molares parece ser bem menor nos casos com pré-molares extraídos do que nos casos sem extração ${ }^{76,126,175}$.

Com certeza, independentemente do protocolo de extrações adotado, quer seja de quatro pré-molares ${ }^{35,36,65,69,70,72,76}$ ou extrações assimétricas $^{28,65,66,69,70,71,72,128,185}$, pode-se constatar que os terceiros molares movem-se para frente, verticalizam-se, assumindo melhor posição e angulação para irrupção nos casos tratados com extrações dentárias.

Em consonância com vários autores, verificou-se que os aspectos relacionados à correção da Classe II, subdivisão, de acordo com sua etiologia de aparecimento $^{3,11,65,66,69,70,71,86,145}$ já foram bem especulados na literatura, discutindo- 
se os efeitos colaterais e benéficos da sistemática de tratamento simétrica e assimétrica $^{25,28,72,83,128,167}$. Entretanto, a literatura compulsada não relatou estudos que relacionam a assimetria de posição dos terceiros molares com a má oclusão de Classe II, subdivisão. Embora a presença e angulação dos terceiros molares superiores, nas más oclusões de Classe I, sem e com extrações simétricas de quatro pré-molares ${ }^{76}$ e na Classe II bilateral, tratada sem e com extrações de prémolares superiores ${ }^{76,126}$ tenham sido explorados, havia ainda dúvidas quanto à possibilidade do espaço disponível para irrupção e angulação dos terceiros molares serem influenciados pela má oclusão assimétrica.

Avaliando-se terceiros molares em panorâmicas, não houve a prevalência da impacção destes dentes ser mais freqüente em um dos lados ${ }^{56,58,161}$. Em exames radiográficos de terceiros molares em desenvolvimento, verificou-se uma variação considerável no grau de angulação de um indivíduo para outro e mesmo entre os lados direito e esquerdo do mesmo paciente ${ }^{135}$. Foram observadas que as alterações médias nas angulações dos terceiros molares ora se assemelhavam ${ }^{54,137}$, ora apresentavam angulações distintas entre os lados direito e esquerdo ${ }^{175}$, não apresentando diferenças estatisticamente significantes. Desta forma, sugeriu-se que as discrepâncias de posição bilateral dos terceiros molares apresentam alterações posicionais e movimentos eruptivos impresumíveis ${ }^{54}$. Mais tarde, constatou-se uma assimetria entre os lados esquerdo e direito em relação à impacção e irrupção dos terceiros molares, quando se comparou o espaço retromolar entre os lados dos mesmos pacientes ${ }^{55}$. Contrariamente, não houve diferença significante para a angulação bilateral dos terceiros molares, apesar de existir uma diferença angular média de $20^{\circ}$ entre os lados destes dentes. Entretanto, estes trabalhos ${ }^{17,30,54,55,56,58,135,161}$ não se preocuparam em classificar ortodonticamente as más oclusões presentes como critério de seleção dos pacientes. Ainda mais, não mostraram associação de impacção destes molares entre os lados em arcos assimétricos, especificamente nas más oclusões de Classe II, subdivisão dentoalveolares. Além disso, alguns ${ }^{54,55,56}$ ficaram restritos a uma amostragem de estudantes que iriam ser submetidos a extrações de molares retidos assintomáticos, sendo trabalhos publicados em periódicos voltados à especialidade de Cirurgia e 
Patologia Bucal, visando orientar os clínicos na correta indicação da extração destes dentes.

Desta forma, esta pesquisa esclareceu as implicações da inter-relação entre os espaços destinados à irrupção dos terceiros molares superiores e inferiores e suas angulações nos casos com discrepância sagital assimétrica. Além disso, permitiu estabelecer um prognóstico quanto a impacção dos terceiros molares em relação ao lado da subdivisão uma vez que ainda não tinham sido originados trabalhos que esclarecessem a necessidade de indicar extrações de terceiros molares em arcos assimétricos. Praticamente, as extrações de terceiros molares sempre foram realizadas nos quatro quadrantes de forma simétrica durante e após a mecânica ortodôntica, sem que houvesse questionamentos sobre a real necessidade para que tal protocolo fosse realizado. Portanto, este trabalho contribuiu para indicar protocolos de extração de terceiros molares nos casos de Classe II, subdivisão na clínica ortodôntica, auxiliando ortodontistas, e também os cirurgiões, no diagnóstico frente ao tratamento dos terceiros molares não irrompidos assintomáticos.

\section{Sugestões para futuras pesquisas:}

- Comparar grupos de Classe II, subdivisão, Tipo 1 e Tipo 2, adotando-se os mesmos critérios da metodologia deste trabalho, utilizando-se de um maior número de pacientes.

- Avaliar as alterações no pós-tratamento do espaço destinado à irrupção e a angulação dos terceiros molares superiores e inferiores nos casos de Classe II, subdivisão tratados com extrações assimétricas de pré-molares. 


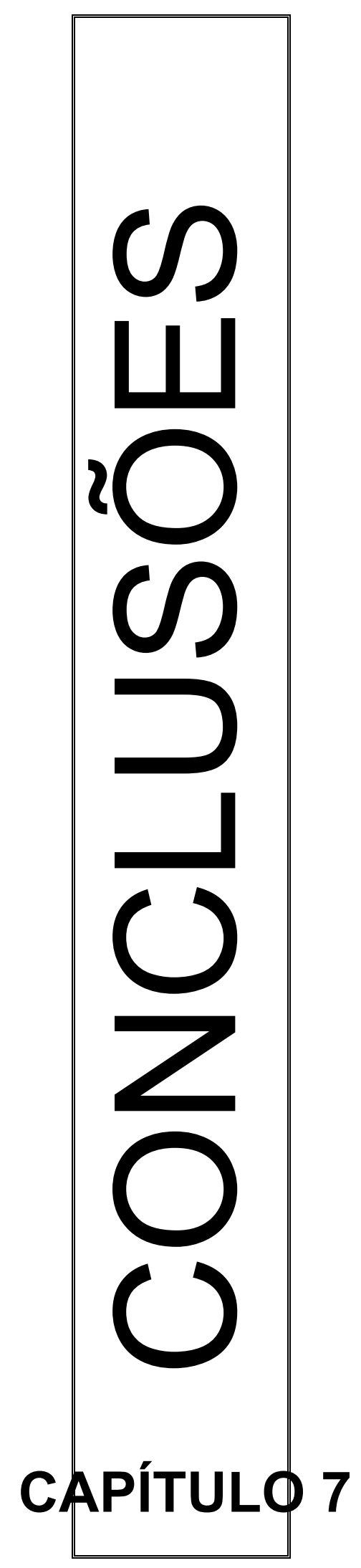




\section{7- CONCLUSÕES}

\section{B}

aseando-se nos resultados obtidos neste trabalho e de acordo com a metodologia utilizada, concluiu-se que:

1. A hipótese nula foi rejeitada uma vez que houve diferenças nos espaços disponíveis superior e inferior e nas angulações dos terceiros molares inferiores entre os lados de Classe I e de Classe II, na má oclusão de Classe II, subdivisão.

2. Na Classe II subdivisão Tipo 1, os espaços disponíveis para os terceiros molares superiores e inferiores $\mathrm{e}$ as angulações dos terceiros molares inferiores refletiram as características do posicionamento dentoalveolar em suas bases apicais nesse tipo de má oclusão.

3. Na Classe II subdivisão Tipo 2, os espaços disponíveis para os terceiros molares superiores e suas angulações tenderam a refletir as características do posicionamento dentoalveolar em suas bases apicais nesse tipo de má oclusão. 


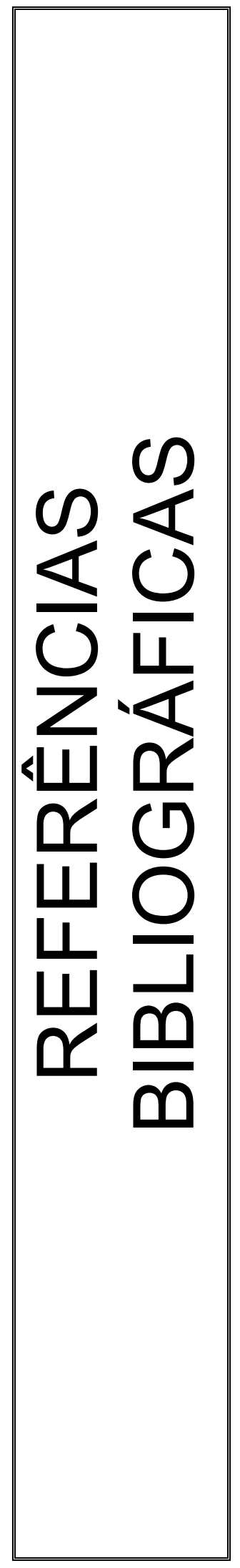




\section{REFERÊNCIAS BIBLIOGRÁFICAS*:}

1. AitASALO, K.; LEHTINEN, R.; OKSALA, E. An orthopantomographic study of prevalence of impacted teeth. Int. J. Oral. Surg., v.1, n.1, p.117-20, Jan. 1972.

2. AKCAM, M.O.; ALTIOK, T.; OZDILER, E. Panoramic radiographs: a tool for investigating skeletal pattern. Amer. J. Orthodont. Dentofac. Orthop. v.123, n.2, p.175-81, Feb. 2003.

3. ALAVI, D.G.; BEGOLE, E.A.; SCHNEIDER, B.J. Facial and dental arch asymmetries in Class II subdivision malocclusion. Amer. J. Orthodont. Dentofac. Orthop., v.93, n.1, p.38-46, Jan. 1988.

4. ALIING, C.C., HELFRICK, J.F.; ALLING, R.D. Impacted teeth. Philadelphia, W.B. Saunders, 1993, p.46-9.

5. ALLATAR, M.M.; BAUGHMAN, R.A.; COLLETT, W.K. A survey of panoramic radiographs for evaluation of normal and pathologic findings. Oral Surg. v.50, n.5, p.472-8, Nov. 1980.

6. ALTONEN, M.; HAAVIKKO, K.; MATTILA, K. Developmental position of lower third molar in relation to gonial angle and lower second molar. Angle Orthodont. v.47, p.249-55, 1977.

7. AMIR, C. et al. Evaluation of the precision of dimensional measurements of the mandible on panoramic radiographs. Oral Surg. v.86, n.2, p.242-8, Aug. 1998.

8. ANGLE, E. H. Malocclusion of the teeth. 7ed. Philadelphia, S.S. White, 1907.

* Normas recomendadas para uso no âmbito da Universidade de São Paulo, com base no documento "Referências Bibliográficas: exemplos", emanado do Conselho Supervisor do Sistema Integrado de Bibliotecas da USP, em reunião de 20 de setembro de 1990. 
9. ARNOLD, T.G.; ANDERSON, G.C.; LILYEMARK, W.F. Assessment of craniofacial asymmetry with S-V radiographs. Amer. J. Orthodont. Dentofac. Orthop. v.106, n.3, p.250-6, Sept. 1994.

10. ÁVILA, M.A.G. Análise das distorções da imagem radiográfica em diferentes aparelhos panorâmicos. Bauru, 1996. 124p. Dissertação (Mestrado) - Faculdade de Odontologia de Bauru, Universidade de São Paulo.

11. AZEVEDO, A.R.P. Correlação entre a assimetria clínica e a assimetria radiográfica na Classe II, subdivisão. Bauru, 2003. 159p. Dissertação (Mestrado) - Faculdade de Odontologia de Bauru, Universidade de São Paulo.

12. BARBER, T.K.; PRUZANSKY, S.; KINDELPERGER, R. An evaluation of the oblique cephalometric film. J. dent. Child. v.28, n.2, p.94-105, 1961.

13. BAUMRIND, S.; FRANTZ, R. The reliability of the head film measurements. Amer. J. Orthodont. v.60, n.2, p.111-27, Aug. 1971.

14. BEHERENTS, R.G. A treatise on the continuum of growth in the aging craniofacial skeleton. Ann Arbor, Michigan, 1984. PhD Thesis Craniofacial Growth Center, University of Michigan.

15. BERGER, H. Problems and promises of basilar view cephalograms. Angle Orthodont. v.31, n.4, p.237-45, Oct. 1961.

16. BERGER, H. Progress with basilar view cephalograms. Trans. Eur. Orthodont. Soc. v.40, p.159-64, 1964.

17. BERGSTRÖM, K.; JENSEN, R. Responsability of the third molar for secondary crowding. Dent. Abstr. v.6, n.9, p.544-5, Sept. 1961. 
18. BISHARA, S.E. Third molars: a dilemma! Or is it? Amer. J. Orthodont. Dentofac. Orthop. v.115, n.6, p.628-33, June 1999.

19. BJERKLIN, K.; KUROL, J. Ectopic eruption of the maxillary first permanent molars: etiologic factors. Amer J Orthodont Dentofac Orthop. v.84, n.2, p.147-55, Aug. 1983.

20. BJÖRK, A.; JENSEN, E.; PALLING, M. Mandibular growth and third molar impactions. Acta Odont. Scand. v.14, p.231-72, Nov. 1956.

21. BRAUN, S. Achieving improved visualization of the temporomandibular joint condyle and fossa in the saggital cephalogram and a pilot study of their relationships in habitual occlusion. Amer. J. Orthodont. Dentofac. Orthop. v.109, n.6, p.635-8, June 1996.

22. BROADBENT, B.H. The influence of the third molars on the alignment of the teeth. Amer. J. Orthodont. Oral Surg. v.29, n.6, p.312-30, June 1943.

23. BROWN, I.D. The unpredictable lower third molar: a case report. Brit. Dent. J. v.136, n.19, p.155-6, Feb. 1974.

24. BRUKS, A. et al. Radiographic examinations as an aid to orthodontic diagnosis and treatment planning. Swed. dent. J. v.23, n.2/3, p.77-85, 1999.

25. BURSTONE, C.J. JCO interviews: on the uses of the computer in orthodontic practice (Part 1). J. clin. Orthodont. v.13, n.7, p.442-53, July 1979.

26. CARTWRIGHT, L.J.; HARVOLD, E. Improved radiographic results in cephalometry through the use of high kilovoltage. J. Can. Dent. Ass., v.20, p.261-3, 1954. 
27. CASSIDY, D.W. et al. A comparison of surgery and orthodontics in "borderline" adults with Class II, division 1 malocclusions. Amer. J .Orthodont. Dentofac. Orthop. v.104, n.5, p.455-70, Nov 1993.

28. CRUZ, K.S. Avaliação das alterações dentoesqueléticas decorrentes do tratamento da má oclusão de Classe II, subdivisão por meio das radiografias submentonianas e póstero-anterior. Bauru, 2000. 236p. Dissertação (Mestrado) - Faculdade de Odontologia de Bauru, Universidade de São Paulo.

29. CRUZ, K.S.; HENRIQUES, J.F.C.; DAINESI, E.A.; JANSON, G. Efeitos dos aparelhos ortopédicos funcionais na correção da má oclusão de Classe II. Rev. Dental Press Ortod. Ortop Facial. v.5, n.4, p.43-52, jul./ago. 2000.

30. DACHI, S.F.; HOWELL, F.V. A survey of 3.874 routine full-mouth radiographs. Oral Surg. Oral Med. Oral Pathol. v.14, n.10, p.1165-90, Oct. 1961.

31. DAHLBERG, G. Statistical methods for medical and biological students. New York, Interscience, 1940.

32. DAWSON, P.E. Evaluation, diagnosis and treatment of occlusal problems. St. Louis, C.V. Mosby Co.,1974.

33. DIERKES, D.D. An investigation of the mandibular third molars in orthodontic cases. Angle Orthodont. v.45, n.3, p.207-12, July 1975.

34. ENGSTRÖM, C.; ENGSTRÖM, H.; SAGNE, S. Lower third molar development in relation to skeletal maturity and chronological age. Angle Orthodont. v.53, n.2, p.93-106, Apr. 1983.

35. FANNING, R.J. The role of extractions in orthodontic treatment. Int. J. Orthodont. v.2, p.17-26, 1964. 
36. FAUBION, B.H. Effect of extraction of premolars on eruption of mandibular third molars. J. Amer. Dent. Ass. v.76, p.316-20, 1968.

37. FORD, J.W. The unerupted third molar from an orthodontic point of view. J. Amer. Dent. Ass. v.27, n.12, p.1863-72, Dec.1940.

38. FORSBERG, C.M; VINGREN, B.; WESSLÉN, U. Mandibular third molar eruption in relation to available space as assessed on lateral cephalograms. Swed. dent. J. v.13, n.1-2, p.23-31, 1989.

39. FORSBERG, C.T; BURSTONE, C.J.; HANLEY, K.J. Diagnosis and treatment planning of skeletal asymmetry with the submental-vertex radiograph. Amer. J. Orthodont. v.85, n.3, p.224-37, Mar. 1984.

40. GARN, S.M.; LEWIS, A.B. The relationship between third molar agenesis and reduction in tooth number. Angle Orthodont. v.32, p.14-18, 1962.

41. GARN, S.M.; LEWIS, A.B.; BONNÉ, B. Third molar formation and its developmental course. Angle Orthodont. v.32, n.4, p.270-9, Oct. 1962.

42. GIAMBATTISTINI, C. Evaluation of accuracy of the $45^{\circ}$ oblique and corrected oblique in assessing mandibular asymmetry. Toronto, 1997. 130p. Master's Thesis - Faculty of Dentistry, University of Toronto.

43. GILBERT, D.H. Radiograph method of basilar cephalometrics. Amer. J. Orthodont. v.46, n.5, p.384-5, May 1960.

44. GILBERT, S.G. Orthodontics and the panorex X-ray. Bul. Philadelphia Co D Soc. v.28, p.11-5, 1962.

45. GOAZ, P.W.; WHITE, S.C. Oral radiology: principles and interpretations. St. Louis, C.V. Mosby, 2ed., p.314-38, 1987. 
46. GOBLIRSCH, A.W. A study of third molar teeth. J. Amer. Dent. Assoc. v.17, p.1849-54, Oct. 1930.

47. GOORIS, C.G.M.; ÄRTUN, J.; JOONDEPH, D.R. Mandibular second molar extraction. Amer. J. Orthodont. Dentofac. Orthop. v.98, p.161-7, 1990.

48. GRABER, T.M. Panoramic radiography in dentistry. J. Canad. dent. Ass. v.31, n.3, p.158-73, 1965.

49. GRABER, T.M.; KAINEG, T.F. The mandibular third molar: its predictive status and role in lower incisor crowding. Proc. Fin. dent. Soc. v.77, p.37-44, 1981.

50. GRAINGER, R.M. The orthodontic treatment priority index. Vital healthy and statistics. Washington, DC, National Center for Health Statistics, 1967.

51. GRAVELY, J.F. A radiographic survey of third molar development. Brit. Dent. J. v.119, p.397-401, 1965.

52. GRAYSON, B.H. et al. Basilar multiplane cephalometric analysis. Amer. J. Orthodont. Dentofac. Orthop. v.88, n.6, p.503-16, Dec. 1985.

53. GRAYSON, B.H.; MCCARTHY, J.G.; BOOKSTEIN, F. An analysis of craniofacial asymmetry by multiplane cephalometry. Amer. J. Orthodont. Dentofac. Orthop. v.84, n.3, p.217-24, Sept. 1983.

54. HATTAB, F.N. Positional changes and eruption of impacted mandibular third molars in young adults: a radiographic 4-year follow-up study. Oral Surg. Oral Med. Oral Pathol. v.84, n.6, p.604-8, Dec. 1997. 
55. HATTAB, F.N; ABU ALHAIJA, E.S.J. Radiographic evaluation of mandibular third molar eruption space. Oral Surg. Oral Med. Oral Pathol. v.88, n.3, p.28591, Sept. 1999.

56. HATTAB, F.N.; RAWASHDEH, M.A; FAHMY, M.S. Impaction status of third molars in jordanian students. Oral Surg. Oral Med. Oral Pathol. v.79, n.1, p.24-9, Jan 1995.

57. HATTON, M.E; GRAINGER, R.M. Reliability of measurements from cephalograms at the Burlington Orthodontic Research Centre. J. dent. Res. v.37, p.853-9, 1958.

58. HELLMAN, M. Our third molar teeth: their eruption, presence and absence. Dent. Cosmos. v.78, p.750-62, 1936.

59. HELLMAN, M. Some aspects of wisdom teeth and their impaction. Arch Clin. Oral Pathol. v.2, p.125, 1938.

60. HENRY, C.B.; MORANT, G.M. A preliminary study of the eruption of the mandibular third molar in man based on measurements obtained from radiographs, with special references to the problem of predicting cases of ultimate impaction of the tooth. Biometrika. v.28, p.378, 1936.

61. HOUSTON, W.J.B. The analysis of errors in orthodontic measurements. Amer. J. Orthodont. v.83, p.382-90, 1983.

62. HUGGINS, D.G. Eruption of lower third molars following orthodontic treatment. Dent. Pract. v.13, p.209-15, 1963.

63. HUNTER, W.S. Lateral asymmetries of 93 maxillary arches. Acta Odont. Scand. v.11, p.95-9, 1953. 
64. JAGER, A.; KABARITY, A.; SINGELMANN, C. Evaluation of orthodontic treatment with early extraction of four second molars. J. Orofac. Orthop. v.58, n.1, p.30-43, Feb. 1997.

65. JANSON, G. Estudo tridimensional das assimetrias dentárias e esqueléticas na má oclusão de Classe II, subdivisão. Bauru, 1998. 271p. Faculdade de Odontologia de Bauru. Tese (Livre-Docência) Faculdade de Odontologia de Bauru, Universidade de São Paulo.

66. JANSON, G. et al. Three-dimensional evaluation of skeletal and dental asymmetries in Class II subdivision malocclusions. Amer. J. Orthodont. Dentofac. Orthop. v.119, n.4, p.406-18, Apr. 2001.

67. JANSON, G.; MARASSI, C.; CRUZ, K.S. Racionalização dos procedimentos de diagnóstico ortodôntico em RC. Rev. Dental Press Ortodon. Ortop. Facial. v.8, n.5, p.139-55, set./out. 2003.

68. JANSON, G.; METAXAS, A.; WOODSIDE, D.G. Variation in maxillary and mandibular molar and incisor vertical dimension in 12-year-old subjects with excess, normal and short lower anterior face height. Amer. J. Orthodont. Dentofac. Orthop. v.106, n.4, p.409-18, Oct. 1994.

69. JANSON, G.; DAINESI; E.A.; HENRIQUES, J.F.C. Class II, subdivision treatment success rate with symmetric and asymmetric extraction protocols. Amer. J. Orthodont. Dentofac. Orthop. v.124, n.3, p.257-64, Sept. 2003.

70. JANSON, G.; JUNQUEIRA, A.C.; DAINESI, E.A. A assimetria dentária e suas implicações no tratamento ortodôntico: apresentação de um caso clínico. Ortodontia. v.26, n.3, p.68-73, set./dez. 1995.

71. JANSON, G. et al. Orthodontic treatment of subdivision cases. World J. Orthod. v.4, n.1, p.36-46, 2003. 
72. JERROLD, L.; LOWENSTEIN, L.J. The midline: diagnosis and treatment. Amer. J. Orthod. Dentofac. Orthop. v.97, n.6, p.453-62, June 1990.

73. KAHL, B.; GERLACH, R.; HILGERS, D. A long-term, follow-up, radiographic evaluation of asymptomatic impacted third molars in orthodontically treated patients. Int. J. Oral Maxillofac. Surg. v.23, n.5, p.279-85, Oct. 1994.

74. KAJII, T. et al. Presence of third molar germs in orthodontic patients in Japan. Amer. J. Orthodont. Dentofac. Orthop. v.119, n.3, p.245-50, Mar. 2001.

75. KAPLAN, R.G. Some factors related to mandibular third molar impaction. Angle Orthodont. v.45, n.3, p.153-8, July. 1975.

76. KIM, T. et al. Prevalence of third molar impaction in orthodontic patients treated nonextraction and with extraction of 4 premolars. Amer. J. Orthodont. Dentofac. Orthop. v.123, n.2, p.138-45, Feb. 2003.

77. KRAMER, R.M.; WILLIAMS, A.C. The incidence of impacted teeth: a survey at Harlem Hospital. Oral Surg. Oral Med. Oral Pathol. v.29, n.2, p.237-41, Feb. 1970.

78. KRONMILLER, J.E. Development of asymmetries. Semin. Orthodont. v.4, n.3, p.134-7, Sept. 1998.

79. KRUGER, E.; THOMSON, W.; KONTHASINGHE, P. Third molar outcomes from age 18 to 26: findings form a population-based New Zealand longitudinal study. Oral Surg. Oral Med. Oral Pathol. v.92, n.2, p.150-5, Aug. 2001.

80. LAM, P.H.; SADOWSKY, C.; OMERZA, F. Mandibular asymmetry and condilar position in children with unilateral posterior crossbites. Amer. J. Orthodont. Dentofac. Orthop. v.115, n.5, p.569-76, May 1999. 
81. LASKIN, D.M. Evaluation of the third molar problem. J. Amer. Dent. Assoc. v.82, p.824-8, Apr. 1971.

82. LEDYARD, B.C. A study of the mandibular third molar area. Amer. J. Orthodont. v.39, n.4, p.366-73, Apr. 1953.

83. LEGAN, H.L. Surgical correction of patients with asymmetries. Semin. Orthodont. v.4, n.3, p.189-98, Sept. 1998.

84. LEVINE, J.H. Third molar in the evolution of the jaw. Dent. Cosmos. v.59, p.1203-7, Dec. 1917.

85. LEW, K.K.K.; TAY, D.K.L. Submentovertex cephalometric norms in male chinese subjects. Amer. J. Orthodont. Dentofac. Orthop. v.103, n.3, p.247-52, Mar. 1993.

86. LIMA, K.J.R.S. Distribuição dos tipos de Classe II, subdivisão e avaliação de suas assimetrias. Bauru, 2003. 170p. Dissertação (Mestrado) Faculdade de Odontologia de Bauru, Universidade de São Paulo.

87. LUND, T.M.; MANSON-HING, L.R. Relations between tooth positions and focal troughts of panoramic machines. Oral Surg. Oral Med. Oral Pathol. v.40, n.2, p.285-93, Aug. 1975.

88. LUNDSTRÖM, A. Some asymmetries of the dental arches, jaws and skull and their etiological significance. Amer. J. Orthodont. Dentofac. Orthop. v.47, n.2, p.81-106, Feb 1961.

89. LYONS, C.J. Pathological significance of impacted and unerupted teeth. J. N Dent. Assoc. v.3, p.28-46, Jan. 1916. 
90. MACGRECOR, A.J. The radiological assessment of ectopic lower third molars. Ann Roy Coll Surg. v.61, p.105-9, 1979.

91. MARMARY, Y.; SILBERMAN, Y.; MIRSKY, Y. Use of foramina spinosa to determine skull midlines. Angle Orthodont. v.49, n.4, p.263-8, Oct. 1979.

92. MARTINS, D.R.; RAMOS, A.L. Agenesia, impacção e extração dos terceiros molares versus apinhamento ântero-inferior. Rev Dental Press Ortodont. Ortop. Facial. v.2, n.2, p.71-6, mar./abr. 1997.

93. MARTINS de ARAÚJO, T.; SCHIRMER, R.W.; ALMEIDA, M.A. Skeletal and dental arch asymmetries in Class II, division 1 , subdivision malocclusions. $\mathbf{J}$ clin. pediat. Dent. v.18, p.181-5, 1994.

94. MARZOLA, C. Retenção dental: terceiros molares inferiores retidos. 2ed., São Paulo, 1995, p.51-116.

95. MAYORAL, G. Treatment results with light wires studied by panoramic radiography. Amer. J. Orthodont. v.81, p.489-97, 1982.

96. MCDAVID, W.D. et al. Imaging characteristics of seven panoramic x-ray units. Dentomaxillofac Radiol. v.8, p.1-68, 1985.

97. MCKEE, I.W. et al. The acuracy of 4 panoramic units in the projection of mesiodistal tooth angulations. Amer. J. Orthodont. Dentofac. Orthop. v.121, n.2, p.166-75, 2002.

98. MELNIK, A.K. A cephalometric study of mandibular asymmetry in a longitudinally followed sample of growing children. Amer. J. Orthodont. Dentofac. Orthop. v.101, n.4, p.355-66, Apr. 1992. 
99. MERRILL, V. Atlas of roentgenographic positions. Saint Louis, C.V. Mosby, 1949.

100. METAXAS, A. A radiographic study for the assessment of mandibular asymmetry. Athens, 1993. PhD Thesis - University of Athens.

101. MLYNARSKA-ZDUANIAK, E. Angle of inclination of the axes of teeth and buds of permanent teeth in pantomograms in normal occlusion in the early period of tooth exchange. Czas Stomatol. v.36, n.7, p.541-6, 1983.

102. MONGINI, F. Remodelling of the temporomandibular condyle in the adult and its relationship to the conditions of the dental arches. Acta anat. v.82, n.292-300, 1972.

103. MONGINI, F.; SCHMID, W. Treatment of mandibular asymmetries during growth: a longitudinal study. Eur. J. Orthodont. v.9, n.1, p.51-67, Feb. 1987.

104. MORRIS, C.R; JERMAN, A.C. Panoramic radiographic survey: a study of embedded third molars. J. Oral Surg. v.29, n.2, p.122-5, Feb. 1971.

105. MOSS, M.I.; SALENTIJN, I. Differences between the functional matrices in the anterior open bite and in deep overbite. Amer. J. Orthodont. Dentofac. Orthop. v.60, n.6, p.264-80, Sept. 1971.

106. NELSON, R.J.; KUMPULA, J.W. Panographic radiography. J. dent. Res. v.31, n.2, p.158-65, 1952.

107. O'BYRN, B.L. et al. An evaluation of mandibular asymmetry in adults with unilateral posterior crossbite. Amer. J. Orthod. Dentofac. Orthop. v.107, n.4, p.394-400, Apr. 1995. 
108. ODUSANYA, S.A.; ABAYOM, I.O. Third molar eruption among rural nigerians. Oral Surg. Oral Med. Oral Pathol. v.71, p.151-4, 1991.

109. OKESON, J.P. Management of temporomandibular disorders and occlusion. 2ed. Saint Louis, C.V. Mosby, 1989.

110. OLIVE, R.; BASFORD, K. Reliability and validity of lower third molar spaceassessment techniques. Amer. J. Orthodont. Dentofac. Orthop. v.79, p.45-53, 1981.

111. PAATERO, Y.V. A new tomographical method for radiographing curved outer surfaces. Acta Radiol. v.32, p.177-84, 1948.

112. PAATERO, Y.V. Pantomography and orthopantomography. Oral Surg. v.14, n.8, p.941-53, Aug. 1961.

113. PAATERO, Y.V. Pantomography in theory and use. Acta Radiol. v.41, p.321-5, 1954.

114. PELTOLA, J.S.; KONUNEM, M.; NYSTROM, M. Radiographic characteristics in mandibular condyles of orthodontic patients before treatment. Eur. J Orthodont. v.17, n.68-77, 1995.

115. PERLOW, J.A. A full light-arch technique utilizing Bull's principles of extraction treatment with emphasis on twenty-eight teeth. Amer. J. Orthodont. v.50, n.2, p.81-98, Feb. 1964.

116. PETERSON, L.J. Rationale for removing impacted teeth: when to extract or not to extract. J. Amer. Dent. Assoc. v.123, p.198-204, 1992.

117. PHILIPP, R.G.; HURST, R.V. The cant of the occlusal plane and distortion in the panoramic radiograph. Angle Orthodont. v.48, n.4, p.317-23, 1978. 
118. PINTO, A.S. et al. Morphological and positional asymmetries of young children with functional unilateral posterior crossbite. Amer. J. Orthodont. Dentofac. Orthop. v.120, n.5, p.513-20, Nov. 2001.

119. POLLARD, L.E.; MAMANDRAS, A.H. Male postpubertal facial growth in Class II malocclusions. Amer. J. Orthodont. Dentofac. Orthop. v.108, n.1, p.628, July 1995.

120. PONYI, S.; SZABÓ, G.; NYILASI, J. Asymmetry of mandibular dimensions in european skulls. Proc. Fin. dent. Soc. v.87, n.3, p.321-7, July 1991.

121. POSEN, A.L. Vertical height of the body of the mandible and the occlusal level of the teeth in individuals with cleft and non-cleft palates. Chicago, 1957. University of Illinois, Department of Orthodontics, School of Dentistry.

122. POSEN, A.L. Vertical height of the body of the mandible and the occlusal level of the teeth in individuals with cleft and non-cleft palates. J. calif. dent. Assoc. p.211-8, 1958.

123. PROFFIT, W.R.; FIELDS, H.W. Ortodontia contemporânea. 3ed., Rio de Janeiro, Guanabara Koogan, 2002.

124. PROFFIT, W.R.; VIG, K.W.L.; TURVEY, T.A. Early fracture of the mandibular condyles: frequently and unsuspected cause of growth disturbances. Amer. J. Orthodont. Dentofac. Orthop. v.78, p.1-24, 1980.

125. PULLINGER, A.G. et al. Relationship of mandibular condylar position to dental occlusion factors in an asymptomatic population. Amer. J. Orthodont. Dentofac. Orthop. v.91, n.3, p.200-6, Mar. 1987. 
126. PUTRICK, L.M. Presença e angulação dos terceiros molares superiores na má oclusão de Classe II, tratada sem e com extrações de pré-molares superiores. Bauru, 2003. 63p. Dissertação (Mestrado) - Faculdade de Odontologia de Bauru, Universidade de São Paulo.

127. RALLEY, L.; CHAPNICK, P.; BAKER, G. The impacted third molar. J. Canad. dent. Ass. v.43, n.8, p.364-6, 1977.

128. REBELLATO, J. Asymmetric extractions used in the treatment of patiens with asymmetries. Semin. Orthodont. v.4, n.3, p.180-8, Sept. 1998.

129. RICHARDSON, A. A comparison of traditional and computadorized method of cephalometric analysis. Eur. J. Orthodont. v.3, p.15-20, 1981.

130. RICHARDSON, E.R.; MALHOTRA, S.K.; SEMENYA, K. Longitudinal study of three views of mandibular third molar eruption in males. Amer. J. Orthodont. Dentofac. Orthop. v.86, n.2, p.119-29, Aug. 1984.

131. RICHARDSON, M. Lower arch crowding in the young adult. Amer. J. Orthodont. Dentofac. Orthop. v.101, n.2, p.132-7, Feb. 1992.

132. RICHARDSON, M. Pre-eruptive movements of the mandibular third molar. Angle Orthodont. v.48, n.3, p.187-93, July 1978.

133. RICHARDSON, M.E. Aspects of lower third molar eruption. Angle Orthodont. v.44, p.141-5, 1974.

134. RICHARDSON, M.E. The development of third molar impaction. Br. J. Orthodont. v.2, p.231-4, 1975. 
135. RICHARDSON, M E. The early developmental position of the lower third molar relative to certain jaw dimensions. Angle Orthodont. v.40, n.3, p.226-30 July, 1970.

136. RICHARDSON, M.E. The etiology and prediction of mandibular third molar impaction. Angle Orthodont. v.47, p.165-72, 1977.

137. RICHARDSON, M.E. Late lower arch crowding in relation to primary crowding. Angle Orthodont. v.52, n.4, p.300-12, Oct. 1982.

138. RICHARDSON, M.E. Lower molar crowding in the early permanent dentition. Angle Orthodont. v.55, p.51-7, 1985.

139. RICHARDSON, M.E. Lower third molar space. Angle Orthodont. v.57, p.15561, 1987.

140. RICHARDSON, M.E. The relative effects of the extraction of various teeth on the development of mandibular third molars. Trans. Eur. Orthodont. Soc. p.79-85, 1976.

141. RICHARDSON, M.E.; RICHARDSON, A. Lower third molar development subsequent to second molar extraction. Amer. J. Orthodont. Dentofac. Orthop. v.104, p.566-74, 1993.

142. RICKETTS, R.M. A principle of facial growth of the mandible. Angle Orthodont. v.42, p.368-84, 1972.

143. RICKETTS, R.M. Técnica Bioprogressiva de Ricketts. Buenos Aires, Argentina, Ed. Médica Panamericana, 1983, p.366-72. 
144. RITUCCI, R.; BURSTONE, C.J. Use of submental vertical radiograph in the assessment of asymmetry. Farmington, 1981. Certificate in Orthodontics Department of Orthodontics, University of Connecticut.

145. ROSE, J.M. et al. Mandibular skeletal and dental asymmetry in Class II subdivision malocclusions. Amer. J. Orthodont. Dentofac. Orthop. v.105, n.5, p.489-95, May 1994.

146. ROSEN, M.D.; BUTCHER, E.O.; SILVERMAN, S.I. Muscle and skull developmental changes in dogs with induced unilateral anodontia. Oral Surg. v.20, n.5, p.672-5, Nov. 1965.

147. ROTH, R.H. Functional occlusion for the orthodontist. J. clin. Orthodont. v.15, n.1, p.32-51, Jan. 1981.

148. ROTHEMBERG, F. The lower third molar problem. Amer. J. Orthodont. v.31, n.2, p.104-15, Feb. 1945.

149. SALZMANN, J.A. Practice of orthodontics. Philadelphia, Lippincott Co.,1966.

150. SAMAWI, S.S.B.; BURKE, P.H. Angular distortion in the orthopantomogram. Br. J. Orthodont. v.11, n.2, p.100-7, Apr. 1984.

151. SAMFORS, K.A; WELANDER, U. Angle distortion in narrow beam rotation radiography. Acta Radiol. v.15, p.570-6, 1974.

152. SÄMFORS, K.A.; WELANDER, U. Distortion in the pantomogram due to object movement. Svensk Tandlak. v.65, n.4, p.211-15, Apr. 1972.

153. SCARFE, W.C. et al. Radiographic interproximal angulations: implications for rotational panoramic radiography. Oral Surg. Oral Med. Oral Pathol. v.76, p.664-72, 1993. 
154. SCAVONE JR., H. O perfil facial tegumentar dos 13 aos 18 anos de idade: estudo cefalométrico longitudinal em jovens brasileiros leucodermas, com oclusão normal. Bauru, 1996. 217p. Tese (Doutorado) - Faculdade de Odontologia de Bauru, Universidade de São Paulo.

155. SCHERSTÉN, E.; LYSELL, L.; ROHLIN, M. Prevalence of impacted third molars in dental students. Swed. dent. J. v.13, n.1-2, p.7-13, 1989.

156. SCHMID, W.; MONGINI, F.; FELISIO, A. A computer-based assessment of structural and displacement asymmetries of the mandible. Amer. J. Orthodont. Dentofac Orthop. v.100, p.19-34, 1991.

157. SCHUELLER, A. Die Schaedelbasis in Roentgenbild. Fortschr Geb Roentgenstr. v.11, 1905.

158. SCHULHOF, R.J. Third molars and orthodontic diagnosis. J. clin. Orthodont. v.10, n.4, p.272-81, Apr. 1976.

159. SEVERT, T.R; PROFFIT, W.R. The prevalence of facial asymmetry in the dentofacial deformities population at the University of North Carolina. Int. J. Adult Orthodont. Orthog. Surg. v.12, n.3, p.171-6, 1997.

160. SEWERIN, I.P. Radiology in the management of impacted teeth. Int. Dent. J. v.37, n.1, p.25-30, Mar. 1987.

161. SHAH, R.M.; BOYD, M.A.; VAKIL, T.F. Studies of permanent tooth anomalies in 7.886 canadian individuals: congenitally, missing, supernumerary and peg teeth. J. Canad. dent. Ass. v.44, n.6, p.265-8, Jan. 1978.

162. SHAH, S.M.; JOSHI, M.R. An assessment of asymmetry in the normal craniofacial complex. Angle Orthodont. v.48, p.141-7, 1978. 
163. SHANLEY, L.S. The influence of mandibular third molars on mandibular anterior teeth. Amer. J. Orthodont. v.48, n.10, p.786-7, Oct. 1962.

164. SHEATS, R.D. et al. Prevalence of orthodontic asymmetries. Semin. Orthodont. v.4, n.3, p.138-45, Sept. 1998.

165. SHENEMAN, J.R. Third molar teeth and their effect upon lower anterior teeth: a survey of forty-nine orthodontic case five years after band removal. St. Louis University, Master's Thesis, 1968.

166. SHILLER, W.R. Positional changes in mesio-angular impacted mandibular third molars during a year. J. Amer Dent. Assoc. v.99, n.3, p.460-4, Sept. 1979.

167. SHROFF, B.; SIEGEL, S.M. Treatment of patients with asymmetries using asymmetric mechanics. Semin. Orthodont. v.4, n.3, p.165-79, Sept. 1998.

168. SIEGEL, M.A. A matter of Class: interpreting subdivision in a malocclusion. Amer. J. Orthodont. Dentofac. Orthop. v.122, n.6, p.582-6, Dec. 2002.

169. SILLING, G. Development and eruption of the mandibular third molar and its response to orthodontic therapy. Angle Orthod. v.43, n.3, p.271-8, July 1973.

170. SJURSEN, R.C.; LEGAN, H.L.; WERTHER, J.R. Case report: assessment, documentation and treatment of a development facial asymmetry following early childhood injury. Angle Orthod. v.69, n.1, p.89-94, Feb. 1999.

171. SLAVICEK, R. JCO Interviews: on clinical and instrumental functional analysis for diagnosis and treatment planning (Part 1). J. clin. Orthodont. v.22, n.6, p.358-70, June 1988. 
172. STAGGERS, J.A. A comparison of results of second molar and first premolar extraction treatment. Amer. J. Orthodont. Dentofac Orthop. v.98, p.430-6, 1990.

173. STAGGERS, J.A.; GERMANE, N.; FORTSON, W.M. A comparison of the effects of first premolar extractions on third molar angulation. Angle Orthodont. v.62, n.2, p.135-8, Summer 1992.

174. TAIT, R.V. Further observations on lower third molar tilt. Brit. J. Orthodont. v.11, n.4, p.200-4, Oct. 1984.

175. TAIT, R.V. Mesial migration and lower third molar tilt. Brit. J. Orthodont. v.9, n.1, p.41-7, Jan, 1982.

176. TAIT, R.V.; WILLIAMS, M. Factors influencing the primary inclination of lower third molar crypts. Brit. J. Orthodont. v.5, n.1, p.41-5, Jan. 1978.

177. TALLENTS, R.H. et al. Angular and linear comparisions with unilateral mandibular asymmetry. J. craniomandibular dis. fac. oral pain. v.5, n.2, p.135-41, May 1991.

178. TAVANO, O. et al. Determinação de linhas de referência para medições angulares em radiografias ortopantomográficas. Odont Mod. v.16, n.4, p.361-70, 1989.

179. THUROW, R.C. Cephalometric methods in research and private practice. Angle Orthod. v.21, p.104-16, 1951.

180. TURLEY, P.K. A computerized method of forecasting third molar space in the mandibular arch. NIDR Meeting, 1974. 
181. URSI, W. et al. Assessment of mesiodistal axial inclination through panoramic radiography. J. Clin. Orthodont. v.24, p.166-73, 1990.

182. VEGO, L. A longitudinal study of mandibular arch perimeter. Angle Orthodont. v.32, n.3, p.187-92, July 1962.

183. VENTÄ, I.; MURTOMAA, H.; YLIPAAVALNIEMI, P. A device to predict lower third molar eruption. Oral Surg. Oral Med. Oral Pathol. v.84, n.6, p.598608, Dec. 1997.

184. VENTÄ, I. et al. Assessing the eruption of lower third molars on the basis of radiographic features. Brit. J. Oral Maxillofac. Surg. v.29, n.4, p.259-62, Ago 1991.

185. WERTZ, R.A. Diagnosis and treatment planning of unilateral Class II malocclusion. Angle Orthodont. v.45, n.2, p.85-94, Apr. 1975.

186. WILKINSON, L. et al. Systat for Windows: statistics. 5ed. Evanston II, 1992, p.750.

187. WILLIAMSON, E.H. JCO interviews: on occlusion and TMJ dysfunction (Part 1). J. clin. Orthodont. v.15, n.5, p.333-50, May 1981.

188. WILLIAMSON, E.H.; SIMMONS, M.D. Mandibular asymmetry and its relation to pain disfunction. Amer. J. Orthodont. Dentofac. Orthop. v.76, n.6, p.61217, Dec. 1979.

189. WILLIAMSON, E.H; WILSON, C.W. Use of submental-vertex analysis for producing quality temporomandibular joint laminagraphs. Amer. J. Orthodont. Dentofac Orthop. v.70, n.2, p.200-7, Aug. 1976. 
190. WOODSIDE, D.G. The diagnosis and treatment of mandibular asymmetry. University of Toronto, Department of Orthodontics - Continuous Education, 1990.

191. WOODSIDE, D.G. Distance, velocity and relative growth rate standards for mandibular growth for canadian males and females aged three to twenty years. Toronto, 1968. PhD Thesis - Faculty of Dentistry, University of Toronto.

192. WOODSIDE, D.G. A serial study of mandibular growth - accelerations in a large population of canadian males and females aged to three to twenty years. In: HOSL, E.; BALDAUF, A. eds. Mechanical and biological basis in orthodontic therapy. - Heidelberg, Huthig, 1991.

193. WOODSIDE, D.G.; HARVOLD, E.P. The radiographic assessment of facial asymmetry. Toronto, Faculty of Dentistry, University of Toronto, Department of Orthodontics, 1988.

194. XIE, Q. et al. Effect of head positioning in panoramic radiography on vertical measurements: an in vitro study. Dentomaxillofac Radiol. v.25, p.61-6, 1996.

195. ZAR, J.H. Biostatistical analysis. New Jersey, Prentice Hall, 1996. 


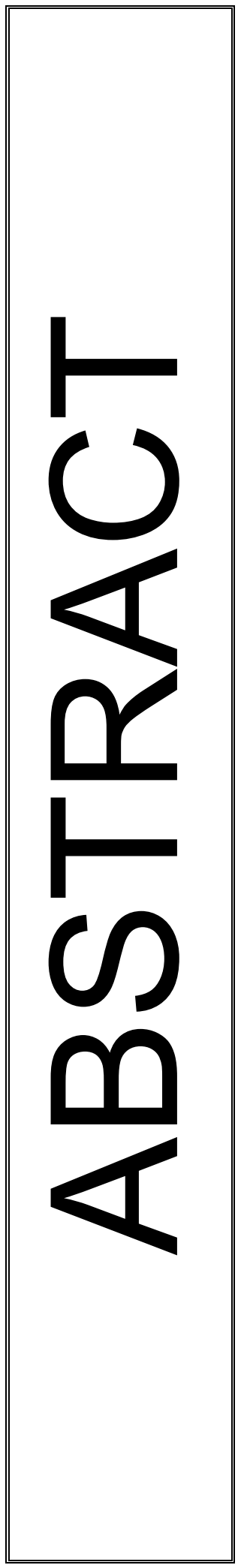




\section{ABSTRACT}

THIRD MOLAR POSITION IN CLASS II, SUBDIVISION MALOCCLUSION

$\mathrm{T}$ he purpose of this research was to compare the available space and inclination of the mandibular and maxillary third molars between the Class I and Class II sides in subjects presenting Class II, subdivision malocclusions. An experimental group of 29 Class II, subdivision patients (17 males and 12 females) with a mean age of 14.73 years and a normal occlusion control group of 17 patients ( 11 females and 6 males) with a mean age of 21.73 years were used in this study. Two subgroups were selected among the total subdivision group according to the two different etiologies: Type 1 subgroup (18 cases) presented a coincidence of the maxillary dental midline with the facial midline and a deviation of the mandibular dental midline. Type 2 subgroup (6 cases) presented deviation of maxillary midline and coincidence of mandibular midline with the facial midline. One submentovertex, two obliques and one panoramic radiograph were taken from each of the 46 subjects of the groups. Dependent $t$ tests were used to compare the available space and the third molar angular measurements of both sides among each group and subgroups individually. Independent t tests were used to compare the linear and angular asymmetries of the available space and angulation of the third molars between the experimental and the control groups. Results demonstrated that there were differences between the Class I and the Class II sides in the available space for the maxillary and mandibular third molars and in the angulation of the mandibular third molars in Class II subdivision malocclusions. In Type 1 Class II subdivision malocclusions the available maxillary and mandibular spaces and the mandibular third molar angulation reflected their characteristic dentoalveolar positioning in their apical bases in this type of malocclusion. In Type 2 Class II subdivision malocclusions the available maxillary and mandibular spaces and the mandibular third molar angulation tended to reflect their characteristic dentoalveolar positioning in their apical bases in this type of malocclusion. 


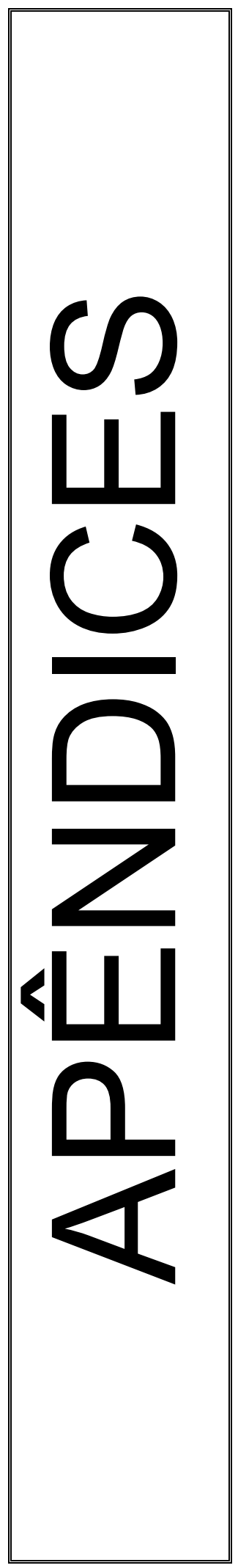




\section{A P Ê N D CES}

TABELA A1 - Características dos pacientes do grupo 1 (Classe II, subdivisão).

\begin{tabular}{|c|c|c|c|c|c|c|c|}
\hline Pacientes & Gênero & $\begin{array}{c}\text { Tipo de } \\
\text { Classe II }\end{array}$ & D.N. & Data Rx & Idade & Direito & Esquerdo \\
\hline A.O.B. & $\mathrm{M}$ & 1 & 14.08 .83 & 13.04 .96 & 12,67 & Cl. I & Cl. II \\
\hline A.L.G.S. & $\mathrm{F}$ & 2 & 29.04 .84 & 12.06 .96 & 12,12 & Cl. II & Cl. I \\
\hline A.W.D.G. & $M$ & Dúvida & 19.05.76 & 10.08 .96 & 20,24 & Cl. II & Cl. I \\
\hline A.C.M.J. & $M$ & 1 & 05.11 .83 & 06.04 .96 & 12,42 & Cl. I & Cl. I \\
\hline 5 B.L.M.E & $\mathrm{F}$ & 1 & 03.09 .86 & 10.06 .02 & 15,75 & Cl. II & Cl. I \\
\hline C.Q. & $\mathrm{F}$ & 1 & 10.10 .83 & 02.04 .96 & 12,48 & Cl. I & Cl. II \\
\hline 7 C.B.S. & $M$ & 1 & 25.07 .80 & 30.03 .96 & 15,69 & Cl. I & Cl. II \\
\hline C.A.A. & $M$ & 1 & 09.06 .76 & 07.10 .95 & 19,33 & Cl. II & Cl. I \\
\hline 9 D.F.R.S. & $M$ & 2 & 05.05 .79 & 14.02 .96 & 16,79 & Cl. I & Cl. II \\
\hline 10 E.P. & $\mathrm{F}$ & 1 & 03.03 .81 & 04.04 .96 & 15,09 & Cl. II & Cl. I \\
\hline 11 F.S.S. & $M$ & Dúvida & 11.05 .83 & 06.04 .96 & 12,91 & Cl. I & Cl. II \\
\hline 12 G.N.T. & $M$ & 1 & 20.06 .88 & 11.03 .02 & 13,75 & Cl. I & Cl. II \\
\hline 13 G.F.M.C. & $\mathrm{F}$ & 1 & 08.07 .88 & 01.02 .02 & 13,58 & Cl. I & Cl. II \\
\hline 14 I.R.C. & $\mathrm{F}$ & 2 & 19.05 .87 & 05.02 .02 & 14,75 & Cl. I & Cl. II \\
\hline 15 I.A. & $M$ & 1 & 22.09 .81 & 19.06 .95 & 13,74 & Cl. II & Cl. I \\
\hline 16 J.W.M.O & $\mathrm{M}$ & 1 & 22.10 .89 & 04.02 .02 & 12,33 & Cl. I & Cl. II \\
\hline 17 L.A.S. & $\mathrm{F}$ & 1 & 02.09 .89 & 01.02 .02 & 12,41 & Cl. II & Cl. I \\
\hline 18 L.C.C.S. & $\mathrm{M}$ & 1 & 20.10 .83 & 09.02 .96 & 12,31 & Cl. II & Cl. I \\
\hline 19 L.C.M.F. & $M$ & 1 & 06.04 .88 & 29.04 .02 & 14 & Cl. I & Cl. II \\
\hline 20 M.A.O.F. & $M$ & 2 & 26.09 .81 & 08.02 .96 & 14,37 & Cl. II & Cl. I \\
\hline 21 M.A.O. & $\mathrm{F}$ & 1 & 11.11 .86 & 05.02 .02 & 15,25 & Cl. I & Cl. II \\
\hline 22 P.S.D. & $\mathrm{F}$ & 1 & 02.02 .81 & 30.03 .96 & 15,16 & Cl. II & Cl. I \\
\hline 23 R.M.G. & $\mathrm{M}$ & Dúvida & 04.05 .83 & 06.04 .96 & 12,93 & Cl. II & Cl. I \\
\hline 24 R.Z. & $M$ & 2 & 27.12 .81 & 22.04 .02 & 20,33 & Cl. I & Cl. II \\
\hline 25 R.S. & $\mathrm{M}$ & 1 & 17.12 .86 & 01.02 .02 & 15,16 & Cl. II & Cl. I \\
\hline 26 R.C.M. & $\mathrm{M}$ & 2 & 07.01 .79 & 08.02 .96 & 17,09 & Cl. I & Cl. II \\
\hline 27 S.F.A. & $\mathrm{F}$ & Dúvida & 07.05 .84 & 30.03 .96 & 11,90 & Cl. II & Cl. I \\
\hline 28 S.A.P. & $\mathrm{F}$ & Dúvida & 30.01 .76 & 08.06 .96 & 20,36 & Cl. I & Cl. II \\
\hline 29 W.M.S. & $\mathrm{F}$ & 1 & 21.10 .89 & 05.02 .02 & 12,33 & Cl. II & Cl. I \\
\hline Média & & & & & 14,73 & & \\
\hline
\end{tabular}


TABELA A2 - Características dos pacientes do grupo 2 (oclusão normal).

\begin{tabular}{ll|c|c|c|c|c|c}
\hline \multicolumn{1}{c|}{ Pacientes } & Gênero & DN & Data Rx & Idade & Direito & Esquerdo \\
\hline 1 & A.T.N. & $\mathrm{F}$ & 27.10 .80 & 31.08 .96 & 15,85 & Relação normal & Relação normal \\
\hline 2 & C.A.C. & $\mathrm{F}$ & 25.05 .77 & 28.06 .96 & 19,10 & Relação normal & Relação normal \\
\hline 3 & C.J.C. & $\mathrm{F}$ & 20.08 .80 & 26.10 .95 & 15,19 & Relação normal & Relação normal \\
\hline 4 & D.S.M. & $\mathrm{M}$ & 01.12 .79 & 13.07 .96 & 16,62 & Relação normal & Relação normal \\
\hline 5 & D.A.A. & $\mathrm{F}$ & 08.04 .73 & 24.08 .96 & 23,39 & Relação normal & Relação normal \\
\hline 6 & F.Y. & $\mathrm{M}$ & 25.08 .75 & 24.08 .96 & 21,01 & Relação normal & Relação normal \\
\hline 7 & H.F.S. & $\mathrm{F}$ & 19.02 .80 & 21.11 .95 & 15,76 & Relação normal & Relação normal \\
\hline 8 & J.R.P. & $\mathrm{M}$ & 27.07 .78 & 21.03 .96 & 17,66 & Relação normal & Relação normal \\
\hline 9 & J.K. & $\mathrm{M}$ & 24.06 .75 & 13.04 .96 & 20,81 & Relação normal & Relação normal \\
\hline 10 J.L.D. & $\mathrm{F}$ & 30.06 .76 & 20.04 .96 & 19,81 & Relação normal & Relação normal \\
\hline 11 & L.M.C. & $\mathrm{F}$ & 15.04 .72 & 04.06 .96 & 24,15 & Relação normal & Relação normal \\
\hline 12 & M.H.D. & $\mathrm{F}$ & 16.03 .55 & 28.03 .96 & 41,06 & Relação normal & Relação normal \\
\hline 13 M.F. & $\mathrm{F}$ & 12.08 .72 & 19.04 .96 & 23,70 & Relação normal & Relação normal \\
\hline 14 N.Z.V. & $\mathrm{M}$ & 13.12 .63 & 20.10 .95 & 31,87 & Relação normal & Relação normal \\
\hline 15 & R.T. & $\mathrm{M}$ & 03.10 .71 & 20.10 .95 & 24,06 & Relação normal & Relação normal \\
\hline 16 & S.B. & $\mathrm{F}$ & 02.05 .77 & 28.06 .96 & 19,16 & Relação normal & Relação normal \\
\hline 17 V.A.R.F. & $\mathrm{F}$ & 28.01 .76 & 25.04 .96 & 20,25 & Relação normal & Relação normal \\
\hline Média & & & & 21,73 & & \\
\hline
\end{tabular}


TABELA A3 - Valores reais das variáveis lineares e angulares dos lados de Classe I e de Classe II do grupo 1 (Classe II, subdivisão), nas radiografias oblíquas corrigidas .

\begin{tabular}{l|c|c|c|c|c|c|c|c}
\hline \multicolumn{1}{c}{ PACIENTES } & $\begin{array}{c}\text { DIST2MI- } \\
\text { POSRAM } \\
\text { Classe I }\end{array}$ & $\begin{array}{c}\text { Dist2MS- } \\
\text { POSRAM } \\
\text { Classe I }\end{array}$ & $\begin{array}{c}\text { Ang. } \\
\text { 3MInf. } \\
\text { Classe I }\end{array}$ & $\begin{array}{c}\text { Ang. } \\
\text { 3MSup. } \\
\text { Classe I }\end{array}$ & $\begin{array}{c}\text { DIST2MI- } \\
\text { POSRAM } \\
\text { Classe II }\end{array}$ & $\begin{array}{c}\text { Dist2MS- } \\
\text { POSRAM } \\
\text { Classe II }\end{array}$ & $\begin{array}{c}\text { Ang. } \\
\text { 3Mnf. }\end{array}$ & $\begin{array}{c}\text { Ang. } \\
\text { Classe II } \\
\text { Classe II }\end{array}$ \\
\hline 01-A.O.B. & 40 & 42 & 43 & 65 & 37 & 42 & 39 & 66 \\
\hline 02-A.L.G.S. & 43 & 44 & 92 & 66 & 43 & 43 & 75 & 89 \\
\hline 03-A.W.D.G. & 46 & 47 & 95 & 75 & 43 & 45 & 86 & 70,5 \\
\hline 04-A.C.M.Jr. & 44 & 43 & 52 & 63 & 42 & 44 & 45 & 61 \\
\hline 05-B.L.M.E. & 47 & 46 & 61 & 88,5 & 44 & 46 & 53 & 92 \\
\hline 06-C.Q. & 43 & 42 & 53 & 71 & 39 & 41 & 63 & 59,5 \\
\hline 07-C.B.S. & 42 & 42 & 84 & 72 & 44 & 47 & 84 & 76 \\
\hline 08-C.A.A. & 49 & 48 & 50 & 78 & 46 & 49 & 47 & 82 \\
\hline 09-D.F.R.S. & 51 & 49 & 82 & 67 & 46 & 50 & 71 & 56 \\
\hline 10-E.P. & 43 & 42 & 51 & 64 & 41 & 43 & 63 & 60 \\
\hline 11-F.S.S. & 43 & 42 & 43 & 67 & 45,5 & 48 & 50 & 81,5 \\
\hline 12-G.N.T. & 45 & 44 & 63 & 72 & 43 & 47 & 53 & 70 \\
\hline 13-G.F.M.C. & 37 & 36 & 52 & 83 & 38 & 41 & 53 & 72 \\
\hline 14-I.R.C. & 41 & 40 & 53 & 71 & 43 & 46 & 59 & 79 \\
\hline 15-I.A. & 50 & 49 & 46 & 90 & 46 & 48 & 45,5 & 97 \\
\hline 16-J.W.M.O & 40 & 40 & 33 & 63 & 37 & 41 & 31 & 59 \\
\hline 17-L.A.S. & 45 & 45 & 67 & 73 & 46 & 48 & 67 & 79 \\
\hline 18-L.C.C.S. & 47 & 45 & 56 & 72 & 43 & 47 & 52 & 85 \\
\hline 19-L.C.M.F. & 41 & 42 & 70 & 74 & 43 & 46 & 41,5 & 74 \\
\hline 20-M.A.O.F. & 45 & 45 & 52 & 87 & 47 & 48 & 49 & 100 \\
\hline 21-M.A.O. & 49 & 50 & 55 & 83 & 46,5 & 51 & 38 & 99 \\
\hline 22-P.S.D. & 45 & 46 & 46 & 88 & 44 & 47 & 42 & 90 \\
\hline 23-R.M.G. & 42 & 43 & 45 & 85 & 41 & 45 & 55 & 74 \\
\hline 24-R.Z. & 50,5 & 47,5 & 94 & 90 & 46 & 49 & 45 & 116 \\
\hline 25-R.S. & 43 & 42 & 57 & 66 & 42 & 46 & 45 & 75 \\
\hline 26-R.C.M. & 48 & 48 & 52 & 80 & 48 & 51 & 60 & 85 \\
\hline 27-S.F.A. & 40 & 41 & 53 & 55 & 40 & 45 & 60 & 50 \\
\hline 28-S.A.P. & 42 & 43 & 57 & 107 & 45 & 45 & 48 & 85 \\
\hline 29-W.M.S. & 32 & 36 & 71 & 60 & 31,5 & 37 & 66 & 57 \\
\hline
\end{tabular}


TABELA A4 - Valores reais das variáveis lineares e angulares dos lados esquerdo e direito do grupo 2 (oclusão normal), nas radiografias oblíquas corrigidas.

\begin{tabular}{l|c|c|c|c|c|c|c|c}
\hline \multicolumn{1}{c|}{ PACIENTES } & $\begin{array}{c}\text { Dist2MI- } \\
\text { POSRAM } \\
\text { L.Esquerdo }\end{array}$ & $\begin{array}{c}\text { DIST2MS- } \\
\text { POSRAM } \\
\text { L.Esquerdo }\end{array}$ & $\begin{array}{c}\text { Ang. } \\
\text { 3MInf. } \\
\text { L.Esquerdo }\end{array}$ & $\begin{array}{c}\text { Ang. } \\
\text { 3MSup. } \\
\text { L.Esquerdo }\end{array}$ & $\begin{array}{c}\text { Dist2MI- } \\
\text { POSRAM } \\
\text { L.Direito }\end{array}$ & $\begin{array}{c}\text { DIST2MS- } \\
\text { POSRAM } \\
\text { L.Direito }\end{array}$ & $\begin{array}{c}\text { Ang. } \\
\text { 3MInf. } \\
\text { L.Direito }\end{array}$ & $\begin{array}{c}\text { Ang. } \\
\text { 3MSup. } \\
\text { L.Direito }\end{array}$ \\
\hline 1. A.T.N. & 49,1 & 47 & 69 & 69 & 52,5 & 51,3 & 79 & 71 \\
\hline 2. C.A.C. & 49,1 & 47,8 & 18 & 72 & 50,3 & 49,5 & 18 & 53 \\
\hline 3. C.J.C. & 45 & 44 & 66 & 61,5 & 45 & 44 & 71 & 65 \\
\hline 4. D.S.M. & 50 & 49 & 67 & 88 & 50,5 & 49 & 74 & 82 \\
\hline 5. D.A.A. & 41 & 39,5 & 98 & 77 & 40,5 & 39 & 79 & 73 \\
\hline 6. F.Y. & 50 & 49 & 75 & 74 & 51,5 & 50 & 79 & 73 \\
\hline 7. H.F.S. & 42 & 42 & 62 & 77 & 40 & 39,5 & 58 & 65 \\
\hline 8. J.R.P. & 49,1 & 47,6 & 72 & 86 & 48,6 & 47,1 & 71 & 61 \\
\hline 9. J.K. & 51 & 49 & 101 & 69 & 50 & 49 & 90 & 72 \\
\hline 10. J.L.D. & 44 & 42,5 & 52 & 82 & 44 & 42 & 51 & 67 \\
\hline 11. L.M.C. & 43,5 & 42,5 & 100,5 & 51 & 41,5 & 42 & 97 & 46,5 \\
\hline 12. M.H.D. & 48 & 47 & 73 & 69 & 49 & 47 & 79 & 77 \\
\hline 13. M.F. & 42,5 & 42,5 & 59 & 82 & 42,5 & 41,5 & 80 & 70,5 \\
\hline 14. N.Z.V. & 51 & 50,5 & 83 & 75 & 51,6 & 49 & 85 & 76 \\
\hline 15. R.T. & 51,5 & 48 & 87 & 65 & 51 & 49 & 86 & 70 \\
\hline 16. S.B. & 42 & 41 & 49 & 57 & 40,5 & 40 & 62 & 75 \\
\hline 17. V.A.R.F. & 45,5 & 41 & 76 & 60 & 45 & 42 & 83 & 73 \\
\hline
\end{tabular}


TABELA A5 - Valores absolutos das diferenças entre os lados de Classe I e Classe II do grupo 1 (Classe II, subdivisão), nas radiografias oblíquas corrigidas.

\begin{tabular}{l|c|c|c|c}
\hline \multicolumn{1}{c}{ PACIENTES } & $\begin{array}{c}\text { Dif2MI- } \\
\text { POSRAM }\end{array}$ & $\begin{array}{c}\text { Dif2MS- } \\
\text { POSRAM }\end{array}$ & $\begin{array}{c}\text { DifAng } \\
\text { 3MINF }\end{array}$ & $\begin{array}{c}\text { DifAng } \\
\text { 3MSUP. }\end{array}$ \\
\hline 01-A.O.B. & 3 & 0 & 4 & 1 \\
\hline 02-A.L.G.S. & 0 & 1 & 17 & 23 \\
\hline 03-A.W.D.G. & 3 & 2 & 9 & 4,5 \\
\hline 04-A.C.M.Jr. & 2 & 1 & 7 & 2 \\
\hline 05-B.L.M.E. & 3 & 0 & 8 & 3,5 \\
\hline 06-C.Q. & 4 & 1 & 10 & 11,5 \\
\hline 07-C.B.S. & 2 & 5 & 0 & 4 \\
\hline 08-C.A.A. & 3 & 1 & 3 & 4 \\
\hline 09-D.F.R.S. & 5 & 1 & 11 & 11 \\
\hline 10-E.P. & 2 & 1 & 12 & 4 \\
\hline 11-F.S.S. & 2,5 & 6 & 7 & 14,5 \\
\hline 12-G.N.T. & 2 & 3 & 10 & 2 \\
\hline 13-G.F.M.C. & 1 & 5 & 1 & 11 \\
\hline 14-I.R.C. & 2 & 6 & 6 & 8 \\
\hline 15-I.A. & 4 & 1 & 0,5 & 7 \\
\hline 16-J.W.M.O & 3 & 1 & 2 & 4 \\
\hline 17-L.A.S. & 1 & 3 & 0 & 6 \\
\hline 18-L.C.C.S. & 4 & 1 & 14,5 & 2 \\
\hline 19-L.C.M.F. & 2 & 5 & 18 & 11 \\
\hline 20-M.A.O.F. & 2 & 3 & 3 & 13 \\
\hline 21-M.A.O. & 2,5 & 1 & 17 & 16 \\
\hline 22-P.S.D. & 1 & 1 & 4 & 2 \\
\hline 23-R.M.G. & 1 & 2 & 10 & 11 \\
\hline 24-R.Z. & 4,5 & 1,5 & 49 & 26 \\
\hline 25-R.S. & 1 & 4 & 12 & 9 \\
\hline 26-R.C.M. & 0 & 3 & 8 & 5 \\
\hline 27-S.F.A. & 0 & 4 & 7 & 5 \\
\hline 28-S.A.P. & 3 & 2 & 9 & 22 \\
\hline 29-W.M.S. & 0,5 & 1 & 5 & 3 \\
\hline & & & & \\
\hline
\end{tabular}


TABELA A6 - Valores absolutos das diferenças entre os lados esquerdo e direito do grupo 2 (oclusão normal), nas radiografias oblíquas corrigidas.

\begin{tabular}{ll|c|c|c|c}
\hline \multicolumn{2}{c|}{ Pacientes } & $\begin{array}{c}\text { Dif2MI- } \\
\text { POSRAM }\end{array}$ & $\begin{array}{c}\text { Dif2MS- } \\
\text { POSRAM }\end{array}$ & $\begin{array}{c}\text { DifAng } \\
\text { 3Minf. }\end{array}$ & $\begin{array}{c}\text { DifAng } \\
\text { 3MSup. }\end{array}$ \\
\hline 1. & A.T.N. & 3,4 & 4,3 & 10 & 2 \\
\hline 2. & C.A.C. & 1,2 & 1,7 & 0 & 19 \\
\hline 3. & C.J.C. & 0 & 0 & 5 & 3,5 \\
\hline 4. & D.S.M. & 0,5 & 0 & 7 & 6 \\
\hline 5. & D.A.A. & 0,5 & 0,5 & 19 & 4 \\
\hline 6. & F.Y. & 1,5 & 1 & 1 & 1 \\
\hline 7. & H.F.S. & 2 & 2,5 & 4 & 12 \\
\hline 8. & J.R.P. & 0,5 & 0,5 & 1 & 25 \\
\hline 9. & J.K. & 1 & 0 & 11 & 3 \\
\hline 10. & J.L.D. & 0 & 0,5 & 1 & 15 \\
\hline 11. & L.M.C. & 2 & 0,5 & 3,5 & 4,5 \\
\hline 12. & M.H.D. & 1 & 0 & 6 & 8 \\
\hline 13. & M.F. & 0 & 1 & 21 & 11,5 \\
\hline 14. & N.Z.V. & 0,6 & 1,5 & 2 & 1 \\
\hline 15. & R.T. & 0,5 & 1 & 1 & 5 \\
\hline 16. & S.B. & 1,5 & 1 & 13 & 18 \\
\hline 17. & V.A.R.F. & 0,5 & 1 & 7 & 13 \\
\hline
\end{tabular}


TABELA A7 - Valores reais das variáveis angulares entre os lados de Classe I e Classe II do grupo 1 (Classe II, subdivisão), nas radiografias panorâmicas.

\begin{tabular}{l|c|c|c|c}
\hline \multicolumn{1}{c|}{ PACIENTES } & $\begin{array}{c}\text { Ang3MS } \\
\text { Classe I }\end{array}$ & $\begin{array}{c}\text { Ang3MI } \\
\text { Classe I }\end{array}$ & $\begin{array}{c}\text { Ang3MS } \\
\text { Classe II }\end{array}$ & $\begin{array}{c}\text { Ang3MI } \\
\text { Classe II }\end{array}$ \\
\hline 01-A.O.B. & 133,9 & 23,6 & 131,3 & 26,4 \\
\hline 02-A.L.G.S. & 129,9 & 66,5 & 104,1 & 49,2 \\
\hline 03-A.W.D.G. & 113 & 80,2 & 111,8 & 74,3 \\
\hline 04-A.C.M.Jr. & 123,1 & 40,5 & 124,1 & 29,5 \\
\hline 05-B.L.M.E. & 107,9 & 44,6 & 101,1 & 40,2 \\
\hline 06-C.Q. & 123,8 & 42,5 & 119,9 & 41,1 \\
\hline 07-C.B.S. & 119,9 & 67,8 & 122,3 & 64,2 \\
\hline 08-C.A.A. & 121,7 & 29,8 & 116 & 30,2 \\
\hline 09-D.F.R.S. & 107,8 & 57,2 & 128,2 & 48,9 \\
\hline 10-E.P. & 112,4 & 32,3 & 126,8 & 39,1 \\
\hline 11-F.S.S. & 117,6 & 41 & 114,4 & 36,3 \\
\hline 12-G.N.T. & 126,5 & 46 & 126,4 & 49,3 \\
\hline 13-G.F.M.C. & 106,7 & 37,6 & 118,8 & 37,8 \\
\hline 14-I.R.C. & 128,7 & 43 & 115,2 & 40,6 \\
\hline 15-I.A. & 123,9 & 35,5 & 112,6 & 32,7 \\
\hline 16-J.W.M.O & 137,7 & 18 & 123,2 & 21,6 \\
\hline 17-L.A.S. & 118,4 & 49,3 & 117,7 & 46,5 \\
\hline 18-L.C.C.S. & 119,7 & 37,8 & 114 & 39,6 \\
\hline 19-L.C.M.F. & 129,9 & 32,4 & 129 & 24 \\
\hline 20-M.A.O.F. & 105 & 42,6 & 107,9 & 43 \\
\hline 21-M.A.O. & 90,5 & 39,7 & 107,2 & 20 \\
\hline 22-P.S.D. & 106,9 & 39,5 & 108,3 & 26,1 \\
\hline 23-R.M.G. & 100,2 & 23,4 & 115,6 & 24,1 \\
\hline 24-R.Z. & 81,6 & 80,3 & 57 & 27,4 \\
\hline 25-R.S. & 127,1 & 40,8 & 123,3 & 37,3 \\
\hline 26-R.C.M. & 106,6 & 35,2 & 102,6 & 37,8 \\
\hline 27-S.F.A. & 135,4 & 57,9 & 125,6 & 42,5 \\
\hline 28-S.A.P. & 78,6 & 49,4 & 110,4 & 35,3 \\
\hline 29-W.M.S. & 153,4 & 26,1 & 135,9 & 37,5 \\
\hline & & & & \\
\hline
\end{tabular}


TABELA A8 - Valores reais das variáveis angulares entre os lados esquerdo e direito do grupo 2 (oclusão normal), nas radiografias panorâmicas.

\begin{tabular}{l|c|c|c|c}
\hline \multicolumn{1}{c|}{ PACIENTES } & $\begin{array}{c}\text { Ang3MS } \\
\text { L.Esquerdo }\end{array}$ & $\begin{array}{c}\text { Ang3MI } \\
\text { L.Esquerdo }\end{array}$ & $\begin{array}{c}\text { Ang3MS } \\
\text { L.Direito }\end{array}$ & $\begin{array}{c}\text { Ang3MI } \\
\text { L.Direito }\end{array}$ \\
\hline 01-A.T.N. & 124,4 & 40 & 111,8 & 55,5 \\
\hline 02-C.A.C. & 119,3 & $-0,9$ & 118,9 & 10,7 \\
\hline 03-C.J.C. & 133,3 & 44 & 120,9 & 44,1 \\
\hline 04-D.S.M. & 100,5 & 40,5 & 101,1 & 45,3 \\
\hline 05-D.A.A. & 104,8 & 54,7 & 106 & 75,1 \\
\hline 06-F.Y. & 111,6 & 61,6 & 109,7 & 68,2 \\
\hline 07-H.F.S. & 118,5 & 35,1 & 145 & 33,5 \\
\hline 08-J.R.P. & 105,8 & 58,6 & 126,4 & 52,8 \\
\hline 09-J.K. & 104 & 83,1 & 106,3 & 76 \\
\hline 10-J.L.D. & 107,3 & 40,3 & 111,5 & 39,4 \\
\hline 11-L.M.C. & 137,7 & 72,8 & 132,9 & 76,3 \\
\hline 12-M.H.D. & 114,7 & 60,3 & 112 & 59,9 \\
\hline 13-M.F. & 109,4 & 50,1 & 115,1 & 60,3 \\
\hline 14-N.Z.V. & 115,7 & 52,3 & 118 & 60,8 \\
\hline 15-R.T. & 126,1 & 62 & 127,3 & 69,7 \\
\hline 16-S.B. & 124,1 & 26,9 & 111,1 & 33,7 \\
\hline 17-V.A.R.F. & 119,2 & 54,9 & 121,8 & 66,2 \\
\hline
\end{tabular}


TABELA A9 - Valores absolutos das diferenças entre os lados de Classe I e Classe II do grupo 1 (Classe II, subdivisão), nas radiografias oblíquas corrigidas.

\begin{tabular}{l|c|c}
\hline PACIENTES & DifSubSup. & DifSubInf. \\
\hline 01-A.O.B. & 2,6 & 2,8 \\
\hline 02-A.L.G.S. & 25,8 & 17,3 \\
\hline 03-A.W.D.G. & 1,2 & 5,9 \\
\hline 04-A.C.M.Jr. & 1,0 & 11,0 \\
\hline 05-B.L.M.E. & 6,8 & 4,4 \\
\hline 06-C.Q. & 3,9 & 1,4 \\
\hline 07-C.B.S. & 2,4 & 3,6 \\
\hline 08-C.A.A. & 5,7 & 0,4 \\
\hline 09-D.F.R.S. & 20,4 & 8,3 \\
\hline 10-E.P. & 14,4 & 6,8 \\
\hline 11-F.S.S. & 3,2 & 4,7 \\
\hline 12-G.N.T. & 0,1 & 3,3 \\
\hline 13-G.F.M.C. & 12,1 & 0,2 \\
\hline 14-I.R.C. & 13,5 & 2,4 \\
\hline 15-I.A. & 11,3 & 2,8 \\
\hline 16-J.W.M.O & 14,5 & 3,6 \\
\hline 17-L.A.S. & 0,7 & 2,8 \\
\hline 18-L.C.C.S. & 5,7 & 1,8 \\
\hline 19-L.C.M.F. & 0,9 & 8,4 \\
\hline 20-M.A.O.F. & 2,9 & 0,4 \\
\hline 21-M.A.O. & 16,7 & 19,7 \\
\hline 22-P.S.D. & 1,4 & 13,4 \\
\hline 23-R.M.G. & 15,4 & 0,7 \\
\hline 24-R.Z. & 24,6 & 52,9 \\
\hline 25-R.S. & 3,8 & 3,5 \\
\hline 26-R.C.M. & 4,0 & 2,6 \\
\hline 27-S.F.A. & 9,8 & 15,4 \\
\hline 28-S.A.P. & 31,8 & 14,1 \\
\hline 29-W.M.S. & 17,5 & 11,4 \\
\hline & &
\end{tabular}


TABELA A10 - Valores absolutos das diferenças entre os lados esquerdo e direito do grupo 2 (oclusão normal), nas radiografias oblíquas corrigidas.

\begin{tabular}{l|c|c}
\hline \multicolumn{1}{c|}{ PACIENTES } & DifONSup. & DifONInf. \\
\hline 1. A.T.N. & 12,6 & 15,5 \\
\hline 2. C.A.C. & 0,4 & 11,6 \\
\hline 3. C.J.C. & 12,4 & 0,1 \\
\hline 4. D.S.M. & 0,6 & 4,8 \\
\hline 5. D.A.A. & 1,2 & 20,4 \\
\hline 6. F.Y. & 1,9 & 6,6 \\
\hline 7. H.F.S. & 26,5 & 1,6 \\
\hline 8. J.R.P. & 20,6 & 5,8 \\
\hline 9. J.K. & 2,3 & 7,1 \\
\hline 10.J.L.D. & 4,2 & 0,9 \\
\hline 11.L.M.C. & 4,8 & 3,5 \\
\hline 12.M.H.D. & 2,7 & 0,4 \\
\hline 13. M.F. & 5,7 & 10,2 \\
\hline 14.N.Z.V. & 2,3 & 8,5 \\
\hline 15.R.T. & 1,2 & 7,7 \\
\hline 16. S.B. & 13,0 & 6,8 \\
\hline 17.V.A.R.F. & 2,6 & 11,3 \\
\hline
\end{tabular}


Tabela A11 - Valores absolutos das medidas lineares do $2^{\circ}$ traçado para o erro intra-examinadora de 15 pacientes selecionados aleatoriamente, nas radiografias oblíquas corrigidas.

\begin{tabular}{l|c|c|c|c|c|c|c}
\hline PACIENTES & Gênero & Idade & Grupo & $\begin{array}{c}\text { Dist2MI- } \\
\text { POSRAM } \\
\text { L.Esquerdo }\end{array}$ & $\begin{array}{c}\text { Dist2MI- } \\
\text { POSRAM } \\
\text { L.Direito }\end{array}$ & $\begin{array}{c}\text { DIST2MS- } \\
\text { POSRAM } \\
\text { L.Esquerdo }\end{array}$ & $\begin{array}{c}\text { DIST2MS- } \\
\text { POSRAM } \\
\text { L.Direito }\end{array}$ \\
\hline 01-B.L.M.E. & $\mathrm{F}$ & 15,75 & 1 & 45 & 43 & 45 & 46 \\
\hline 02-C.A.A. & $\mathrm{M}$ & 19,33 & 1 & 49 & 46 & 48 & 49 \\
\hline 03-G.F.M.C. & $\mathrm{F}$ & 13,58 & 1 & 37 & 38 & 36 & 41 \\
\hline 04-I.R.C. & $\mathrm{F}$ & 14,75 & 1 & 43 & 41,5 & 42,5 & 45 \\
\hline 05-J.W.M.O. & $\mathrm{M}$ & 12,33 & 1 & 41,5 & 37 & 41 & 41 \\
\hline 06-L.A.S. & $\mathrm{F}$ & 12,41 & 1 & 47 & 44 & 47 & 46 \\
\hline 07-L.M.C. & $\mathrm{F}$ & 24,15 & 2 & 44 & 42 & 44 & 42 \\
\hline 08-M.H.D. & $\mathrm{F}$ & 41,06 & 2 & 48,5 & 49 & 48 & 48 \\
\hline 09-M.F. & $\mathrm{F}$ & 23,70 & 2 & 41,5 & 42 & 42 & 41,5 \\
\hline 10-N.Z.V. & $\mathrm{M}$ & 31,87 & 2 & 51 & 52,5 & 50,5 & 50 \\
\hline 11-R.S. & $\mathrm{M}$ & 15,16 & 1 & 43 & 42 & 42 & 46 \\
\hline 12-S.F.A. & $\mathrm{F}$ & 11,90 & 1 & 40,5 & 38,5 & 42 & 43 \\
\hline 13-S.B. & $\mathrm{F}$ & 19,16 & 2 & 41,5 & 41 & 40 & 40 \\
\hline 14-V.F. & $\mathrm{F}$ & 20,25 & 2 & 45 & 46 & 41 & 43 \\
\hline 15-W.M.S. & $\mathrm{F}$ & 12,33 & 1 & 32 & 32 & 36 & 38 \\
\hline
\end{tabular}


Tabela A12 - Valores absolutos das medidas angulares do $2^{\circ}$ traçado para o erro intra-examinadora de 15 pacientes selecionados aleatoriamente, nas radiografias oblíquas corrigidas.

\begin{tabular}{l|c|c|c|c}
\hline PACIENTES & $\begin{array}{c}\text { Ang. } \\
\text { 3MInf. } \\
\text { L.Esquerdo }\end{array}$ & $\begin{array}{c}\text { Ang. } \\
\text { 3MInf. } \\
\text { L.Direito }\end{array}$ & $\begin{array}{c}\text { Ang. } \\
\text { 3Msup. } \\
\text { L.Esquerdo }\end{array}$ & $\begin{array}{c}\text { Ang. } \\
\text { 3MSup. } \\
\text { L.Direito }\end{array}$ \\
\hline 01-B.L.M.E. & 63 & 55 & 86 & 90 \\
\hline 02-C.A.A. & 49 & 49 & 77 & 83 \\
\hline 03-G.F.M.C. & 54 & 54 & 84 & 73 \\
\hline 04-I.R.C. & 53 & 61 & 72 & 77 \\
\hline 05-J.W.M.O. & 33 & 31 & 62 & 61 \\
\hline 06-L.A.S. & 67 & 66 & 73 & 80 \\
\hline 07-L.M.C. & 99 & 96 & 53 & 46 \\
\hline 08-M.H.D. & 74 & 78 & 68 & 74 \\
\hline 09-M.F. & 57 & 79 & 82 & 70 \\
\hline 10-N.Z.V. & 81 & 84 & 77 & 76 \\
\hline 11-R.S. & 55 & 47 & 64 & 72 \\
\hline 12-S.F.A. & 52 & 60 & 52 & 49 \\
\hline 13-S.B. & 50 & 63 & 55 & 73 \\
\hline 14-V.F. & 74 & 80 & 62 & 71 \\
\hline 15-W.M.S. & 71 & 67 & 61 & 57 \\
\hline
\end{tabular}


Tabela A13 - Valores absolutos do $2^{\circ}$ traçado para o erro intraexaminadora de 15 pacientes selecionados aleatoriamente, nas radiografias panorâmicas.

\begin{tabular}{l|c|c|c|c}
\hline \multicolumn{1}{c|}{ PACIENTES } & Ang3MSE & Ang3MSD & Ang3MIE & Ang3MID \\
\hline 01-B.L.M.E. & 108 & 103 & 40,6 & 38,5 \\
\hline 02-C.A.A. & 122 & 119 & 30,4 & 31,1 \\
\hline 03-G.F.M.C. & 109 & 115,5 & 34,8 & 36,8 \\
\hline 04-I.R.C. & 128 & 116,8 & 47 & 39,5 \\
\hline 05-J.W.M.O. & 134 & 125 & 21 & 23,5 \\
\hline 06-L.A.S. & 120 & 117 & 49,7 & 44,4 \\
\hline 07-L.M.C. & 137 & 132 & 73 & 79 \\
\hline 08-M.H.D. & 116,7 & 109 & 57,1 & 57,5 \\
\hline 09-M.F. & 110,5 & 118,8 & 49 & 58,8 \\
\hline 10-N.Z.V. & 117,7 & 116 & 54,2 & 58 \\
\hline 11-R.S. & 127 & 122 & 42,5 & 36 \\
\hline 12-S.F.A. & 135 & 128,1 & 61,5 & 46 \\
\hline 13-S.B. & 124 & 112,8 & 27 & 34 \\
\hline 14-V.F. & 118,6 & 121 & 52,5 & 68 \\
\hline 15-W.M.S. & 152 & 133 & 25,5 & 39 \\
\hline
\end{tabular}




\section{FACULDADE DE ODONTOLOGIA DE BAURU}

\section{COMITÊ DE ÉTICA EM PESQUISA}

Bauru. 23 de fevereiro de 2001

\section{Ilmo $\mathrm{Sr}$.}

Prof. Dr. Guilherme do Reis Pereira Janson

FOB USP

\section{Senhor Professor}

$O$ projeto de pesquisa encaminhado a este Comitê de Ética denominado "POSICAO IOOS TEROEIFUS MULAREE NA MA OCLUSÄO IE CLASSE II, SUPDIVIsĂC", de autoria da CD Karina Santana Cruz e sob sua orientaçào, foi enviado ao relator para avaliaçào.

Na reunião de 22 de fevereiro. o parecer do relator, aprovando o projeto, foi aceito pelo Comitè, considerando que nào existem infraçóes éticas pendentes.

Atenciosamente

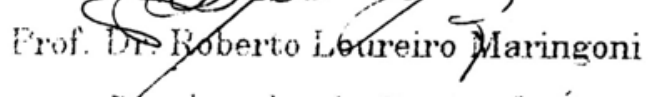

Coordenador do Comite de Ética 